\title{
The Danger between Nature and Culture: The Quotidian Threat of Urban Fires in the Premodern Era
}

The first chapter described the development of premium-based insurance in the Mediterranean and its spread into the northern European realms, and concentrated especially on its counterintuitive, spatially-oriented character. Despite undisputed major continuities in terms of contract modalities and related concepts, there was a change in quantitative terms around $1680-1700-\mathrm{a}$ much wider diffusion of the principle of premium-based insurance beyond the narrow circles of merchants and port cities. Two further qualitative changes also took place-first regarding the various ways in which insurance was institutionalized, and second, in the sense that the dominant characteristic of insurance shifted from the dimension of space to the dimension of time. Since one of the most important elements of the shift around 1700 was concerned with the thematic object areas associated with premium-based insurancenamely, with the turn toward "fire" and "life" - the current chapter will seek to clarify how the reality and perception of the threat of fire, as well as the means of fire prevention and firefighting, were represented and transformed in the premodern era. In the analysis of this transformation-which should primarily be understood as a true epochal threshold in the history of security, occurring around 1700 - I focus, in particular, on major fires, because it is only major fires that can be sufficiently evaluated diachronically and in terms of a large area, such as the German-speaking world. Fire insurance, however, was not created as a response to these major disasters, which in the premodern era constituted something similar to the currently uninsurable "Acts of God". Nevertheless, the great conflagration, the utter annihilation of medieval and Renaissance towns, was the sword of Damocles that hovered over premodern consciousness. The threat of such fires stimulated impulses of fear and anxiety, making fire into the most common and also the greatest fear for the people of this time. It is therefore false to specify the London fire of 1666 as the sole origin of the development of British fire insurance - the reasons for change should be fundamentally located in the cumulative effects of major disasters on the people living in this period. The statistics for major fires will demonstrate that, in light of the continuity of this problem over centuries and the great number of incidents, a simple model that equates "insurance innovation with learning from disasters" hardly addresses the issue. Although not all fires were major 
and extensive, fires were also less easily controlled than they are now; thus, a simple house fire more frequently resulted in the loss of many houses.

In Part 1 of this chapter, I will reconstruct these dimensions of the danger of fire. In Part 2, I will present an inquiry into how the perception of major city fires changed. I will only briefly discuss the treatment of the perception of fires according to the theology of punishment, because this topic is already prominent in existing research. I will, however, discuss the development of this topic in the seventeenth and eighteenth centuries, which demonstrates that while the theology of punishment did not disappear during the century of the Enlightenment - even after the Lisbon earthquake of 1755 - the arguments became increasingly fanned and differentiated in order to correspond to this type of theological interpretation on the one hand, and to developments in philosophy and natural sciences on the other.

The topic of fire also became subject to various forms of visualization, which can be neither reduced to the pure internal development of "l'art pour l'art," (given that premodern art was, to a large extent, already craftmanship, and this holds even more true for works of art produced at the local level of small towns and cities for purposes of commemoration); nor can the characteristics and changes in the forms of visualization be reduced to a simple "reflection" of changes in the real world of developments in the realm of urban planning, building and fire protection. The question is, what change to, and intensification of, emotional motivating forces took place during the centuries that were arising from, and stimulated by the representation and communication of urban fire events? The perception and visual representation of fire danger is therefore understood as a "soft" but relatively significant causal factor driving changes at the institutional level regarding the security provisions put into place both before and after disasters - and as such it is included here on the same categorical level as the developments of such material and useful items such as fire hoses and ladders. This leads, in Part 3 to a brief outline of the notion of pre- and postfire provisions that were not in the form of insurance: from the municipal fire prevention administration (fire policey) $)^{1}$ of the late Middle Ages to the state fire policey of the Enlightenment. This also involves the question of whether, and in what sense, something was "learned" from fire disasters. Among other things, the conceptualization and structure of city reconstruction will be briefly addressed at this point. In particular, I will investigate how technical innovations in fire extinguishers, specifically hoses and related instruments were communicated and implemented from an epistemological-historical perspective.

1 On the premodern concept of "policey," cf. below, Ch. 3, 3. 


\subsection{The "Fire Gap"}

How great was the actual average risk of a major city fire and what trends and developments appear between the Middle Ages and the nineteenth century? This question not only concerns the development of insurance demand, but also addresses the general perspective of cultural as well as environmental history regarding the question of the significance of fires in subsequent eras. The systematic assessment of the problem of city fires is still lacking for many regions and periods: "Despite their importance there have been few attempts by historians to measure trends in the number and cost of fires." ${ }^{2}$

In an essay published in 1989, urban historians Lionel Frost and Eric L. Jones plotted the number of houses destroyed in major fires in twenty large North American cities $^{3}$ during the course of the nineteenth century in relation to the growth of the urban populations. They defined a major fire as one that destroyed over fifty houses. While damages from urban fires significantly increased, city population totals rose exponentially. They called the discrepancy between these two values the "fire gap." This information from across the US was mapped according to geographical location, which suggested a particular trend: the West was initially marked by extremely frequent fires between 1830 and 186o; thereafter, however, the increase in urban populations was substantially more dramatic than in the East. ${ }^{4}$ The "fire gap" quantifiably summarizes the phenomenon at the core of this book: it seems to clearly mark the transition to modernity (Fig. 4).

Urban population growth and fire damage is, of course, linked only graphically - there is no causal connection between these two measures. As the main source for the determination of fire damage, the authors used the Times Index and other sources of local history, although they concede that their list (in particular the number of destroyed houses per fire) is by no means absolute due to various issues associated with source preservation and accessibility. ${ }^{5}$ The fundamental conclusion, that from the 1840 os in the East and the end of the 185 os in the West, the danger of large fires, or at least the danger of major, widespread fires, massively declined, is in any case definitively

2 Robin Pearson, Insuring the Industrial Revolution: Fire Insurance in Great Britain, 1700-1850, Aldershot 2004, pp. 32-33.

3 Baltimore, Boston, Buffalo, Chicago, Cincinnati, Cleveland, Denver, Detroit, Kansas City, Los Angeles, Minneapolis-St. Paul, New Orleans, New York, Omaha, Philadelphia, Pittsburgh, Portland/Ore., St. Louis, San Francisco, Seattle.

4 Lionel E. Frost and Eric L. Jones, "The Fire Gap and the Greater Durability of Nineteenth Century Cities," Planning Perspectives 4 (1989), pp. 333-47, 338-40.

5 Ibid., p. 346 n 15 . 


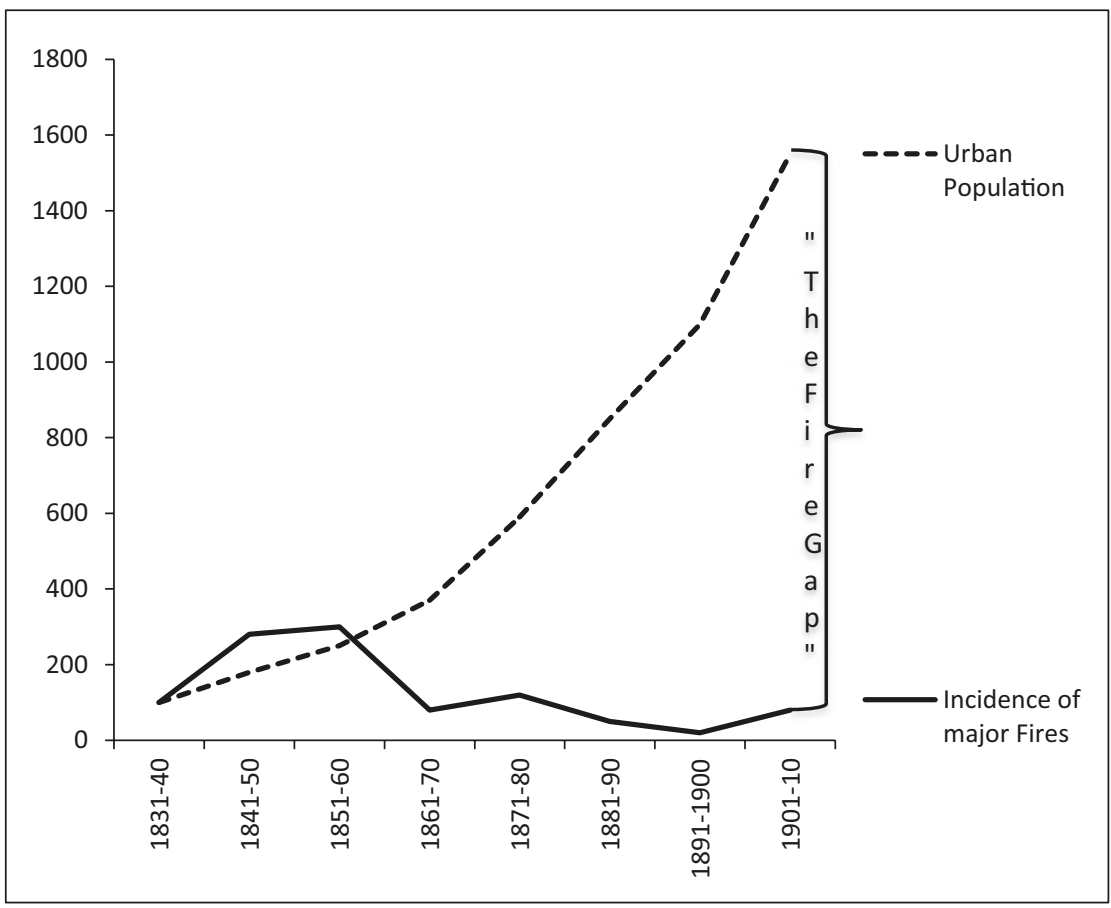

FIGURE 4 The fire gap for the entire USA, 1831-1910, based on Frost/Jones (population growth vs. the number of houses destroyed)

clear-although the best-known fires, including the Chicago fire of 1871, the Boston fire of 1872, and the Baltimore fire of 1904, all happen to be exceptions. The correlation with population increases serves as nothing other than a visualization of the paradox - that this decrease in the overall risk of fire occurs in a period in which explosive population growth would suggest a higher risk of fire. Particularly at the threshold point at the beginning of the nineteenth century, one would assume that the rapid growth of cities would indeed correlate with an increased fire risk. Nevertheless, while there is very little actual informational content in Frost and Jones's "fire gap" graphs, as far as I know, they do represent the first attempt to take stock of the seriality and severity of urban fire risk in international urban history. There have only been a few attempts to systematically address the phenomenon of urban fires. A pioneer among them was the 1984 Gazetteer of English Urban Fire Disasters by Eric L. Jones, Stephen Porter, and Michael Turner, which identifies exactly 518 "definite" and 100 "probable" fires not caused by war that destroyed at least ten houses for the period between 1500 and $1900 .{ }^{6}$ The sources used in this study include

6 I offer Jones/Porter's attempt to formulate a definition of a "major fire" here, because it clearly demonstrates how difficult it is to do so: the "lower-bound definitions of a fire 
"charity briefs" (i.e., begging briefs, licences and privileges, that were issued for the collection of money), ${ }^{7}$ leaflets, newspapers, fire insurance files (from the eighteenth-century on), liturgical books, diaries, and all other conceivable forms of local historiography (chronicles, travel reports, etc.). It is not entirely clear how Porter, Jones, and Turner were aggregating their data from primary sources; nevertheless, it provides a wealth of general information. ${ }^{8}$ Robin Pearson conducted an audit of the Gazetteer by examining every fire reported in three monthlies, focusing specifically on the years $173^{-}-79$. In addition to the 126 fires identified by Jones, Porter, and Turner for this period, Pearson added a further 814; through extrapolations and calculations, he estimated that the 7,600 houses destroyed during these fifty years represented less than a quarter of the entire extent of destruction..$^{9}$ It was thereby confirmed that from $175^{\circ}$ / 60 on, the fire hazard and the rate of destruction generally declined, while the urban population, especially in England, increased considerably - thus suggestive of an earlier fire gap.

For Finland, Eino Jutikkala attempted a project comparable to the Gazetteer on the basis of reports and indications of major fires gathered from urban history in secondary literature..$^{10}$ Of course, it is important to remember that the urbanization of Finland occurred later. Jutikkala finds only seventy-six major fires in twenty-two towns and cities from the sixteenth century until about 186o. The greatest number of fires occurred between 1800 and 1860, while the eighteenth century, in contrast to both the seventeenth and the

disaster ... are at least ten houses destroyed; a significant value of loss in current $£$ s.d.; or a descriptive phrase implying destruction of a high order, such as 'great fire,' 'disastrous fire,' or 'half the town burned.' These phrases may also include figures such as 'eighteen rents lost,' or reports of a large number of buildings burned in which houses were clearly included although the number is not specified" (Eric L. Jones, Stephen Porter, and Michael Turner, A Gazetteer of English Urban Fire Disasters, 1500-1900, Norwich 1984, p. 12).

7 Concerning this type of source see Mark Harris, "Inky Blots and Rotten Parchment Bonds': London, Charity Briefs and the Guildhall Library," Historical Research 66 (1993), pp. 98-110; for a more recent case study of charity briefs after the Great Fire of London see Jacob F. Field, "Charitable Giving and its Distribution to Londoners after the Great Fire, 1666-1676," Urban History 38, 1 (2011), pp. 3-23. The goal of total donations of $£ 16.487$ is, in any case, astonishingly average in light of this major event: national donations via such letters were collected for English seafarers captured by the North African Barbary pirates in the following years:1670-74-£21,530; 1691-96—£8,309; 1700/1—£16,591. See LMA COL CHD PR 07/OO1-003.

8 Jones, Porter, and Turner, A Gazeteer, pp. 7-12.

9 Pearson, Insuring the Industrial Revolution, pp. 32-38.

10 Eino Jutikkala, "Great Fires of Finnish Cities," in Martin Körner (ed.), Stadtzerstörung und Wiederaufbau, vol 1, Zerstörung durch Erdbeben, Feuer und Wasser, Bern 1999, pp. 239-54. 
nineteenth centuries, was blessed with a relative paucity of fires. Jutikkala also provided an average distribution of fires from month to month, with May through September, and especially May and June, being the most fireprone months-perhaps due to the fact that houses were covered with snow during the winter months in Finland. In central Europe, in contrast, the fire danger was at least as high during the dry winter months as it was in the summer. For Sweden, Sven Lilja's evaluation of medieval and early modern urban-historical research found 238 fires in 122 cities between the thirteenth and eighteenth centuries and concluded, in a somewhat revisionist manner, that the importance of fires was lower than commonly assumed-although it is important to remember that Sweden in this period had a very low level of urbanization. ${ }^{11}$ Additionally, it seems that after the Great Northern War (1700-21) in Sweden, the number of fires massively declined over the course of the eighteenth century.

There are no attempts to create such lists of major city fires for most other countries and regions of the globe, although this gap in research is sometimes noted..$^{12}$ For England, many monographs exist about the one (certainly important) Great Fire of London 1666, but "there has been no attempt to synthesize local

11 Sven Lilja, "Wooden Towns on Fire. Fire Destruction and Human Reconstruction of Swedish Towns Prior to 180o," in Körner, Stadtzerstörung, pp. 255-75; cf. Sven Lilja, Städernas folkmängd och tillväxt. Sverige (med Finland) ca 1570-tal till 1810-tal (Historisk tätortsstatistik 2.), Stockholm 1996 - he used as sources for the fire data Medeltidsstaden. The Medieval Town, Town reports, published by Riksantikvarieämbetet; also used: Nils Ahlberg, Stadsplaneförändringar $i$ Sverige 1550-1875, 2 vols., Uppsala 1995, on which the following is based: Nils Ahlberg, Stadsgrundningar och planförändringar: svensk stadsplanering 1521-1721, Uppsala 2005.

12 For the Netherlands, for example: "Een overzicht van alle branden van enige omvang uit deze periode is niet voorhanden” (Marco H.D. van Leeuwen (ed.), De rijke Republiek. Gilden, assuradeurs en armenzorg 1500-1800, The Hague 2000, p. 304); for Czech and Slovakia: "Fire statistics for Bohemian towns and villages can be established only after the appearance of all volumes of the city encyclopedia" that Karel Kuča, Města a městečka v Čechách, na Moravě a ve Slezsku [Cities and small towns in Bohemia, Moravia and Silesia], vol. 1-8, Prague 1996-2011 was then only preparing (Josef Hrdlička, "Beten oder löschen? Feuer in den böhmischen Städten der Frühen Neuzeit," in Lorenzetti, Luigi and Giannò, Vanessa (eds.), Al fuoco! Usi, rischi e rappresentazioni dell'incendio dal Medioevo al XX secolo. Dibattiti \& documenti 13/Studi di storia alpina/Studies on Alpine History 6. (Milan and Lugano: 2010), 91-108, 93n4. Kuča's volumes include a paragraph for each city on catastrophes, with a separate discussion of big city fires (Požáry), as in the German Städtebücher. A statistical analysis has not yet been undertaken. For Romania "Istoriografia românească înregistrează foarte puține preocupări pe tema catastrofelor urbane provocate de foc" (Dan Dumitru Iacob, "Incendiul din Iaşi, din 25 Iunie 1833", Historia Urbana 26 (2018), pp. 67-96, here p. 69 with reference to some works treating individual fires and some works on fire-fighting). 
studies, or to reconcile fires, and the experience of fires, with the growing global and interdisciplinary field of historical disaster studies." ${ }^{13}$ In addition to scattered statements regarding selected cities, there is some information on czarist fire statistics from nineteenth-century Russia - which, however, is not comparable to the above examples ${ }^{14}$ — as well as some very unreliable individual assessments of small sub-regions or assessments of fires named in an arbitrary selection of early modern encyclopedias. ${ }^{15}$ There are some sporadic notes on two hundred fires during the Ch'ing dynasty (1644 and 1673-1912) in China and concerning a few random, large fires in Asian and Islamic cities, ${ }^{16}$ but they are not particularly useful for purposes of comparison. ${ }^{17}$ The following section is therefore an attempt to construct and analyze a fire ecology for Germany on the basis of Keyser's urban history compendia (i.e., the Städtebücher, discussed below). These and other statistical sources from the macro- to the meso- and micro-level of urban networks and particular cities will be evaluated in order to explicate the realities of fire danger at the time. As a result, the contours emerge of a German/Austrian fire ecology and we begin to see the frequencies and distributions of major urban fires. The purpose of this chapter is to create a tangible sense of the dimensions and qualities of fire danger before moving to a discussion of the perceptions and measures of security production that developed in response to that danger.

13 John Morgan, "The representation and experience of English urban fire disasters, c. 15801640", Historical Research 89, 244 (2016), pp. 268-293, p. 269 who adds in n. 8 "Such studies exist for other national and international contexts, but not England."

14 Cathy Frierson, All Russia is burning! A Cultural History of Fire and Arson in Late Imperial Russia, Seattle 2002, pp. 68-71.

15 Jacky Theurot, “'Au feu!' Les bourgs et les ville du comté de Bourgogne face à l'incendie (XIVe et XVe siècles)," in François Lassus and François Vion-Delphin (eds.), Les hommes et le feu de l'Antiquité à nos jours. Du feu mythique et bienfaiteur au feu dévastateur, Besançon 2007, pp. 233-251, 236: regional summary of fire for the late Middle Ages; Christine Lamarre, "Les incendies de villes dans les géographies du XVIIIe siècle," in Lassus/VionDelphin, Les hommes, pp. 283-92 (A list of 35 fires in France according to encyclopedia entries). Similarly arbitrary is the selection of fires found in Maxime Petit, Les grands incendies, Paris 1882, pp. 273-92, which combines 82 Parisian fires since the sixth century with a universal-historical collection of fires from around the world; François Jarrige and Bénedicte Reynaud, "Les usines en feu. L'industrialisation au risque des incendies dans le textile (France 1830-1870)," Le mouvement social 249 (2014), pp. 141-62, 143, 146: Featuring fires from $1804-70$ in five French départements in the textile industry.

16 Cf. Frost and Jones, The Fire Gap, p. 336.

17 Some literature on fire "statistics" concerning individual cities in China is included in selected bibliographical references for chapter 6,4 below; however, these primarily concern the nineteenth century. 


\subsection{8 ,20o Fires in Germany and Austria}

The Städtebücher is a multivolume encyclopedic register of all German and Austrian communities once or still possessing the rights and status of a city. These volumes, the publication of which began in 1939, are the result of a large and multipronged archival research project, and they facilitate a uniquely accurate and precise summary of large urban fires for the German and central European region. ${ }^{18}$ It is often forgotten that the Städtebücher project was a product of National Socialist Volksgeschichte (ethnic history). It was founded by the Danzig archivist and professor Erich Keyser (1893-1968) at the seventh International Congress of History in Warsaw in August $1933 .{ }^{19}$ The particular element that made the Städtebücher unique was the attention devoted to "small and smallest cities." ${ }^{20}$ Keyser organized a host of contributors from the Institutes for Regional History Publication (Konferenz der landesgeschichtlichen Publikationsinstitute), the Historical Commissions of the States (Historischen Kommissionen der Länder), the German Assembly of Cities (Deutscher Gemeindetag), and experts

18 Erich Keyser (ed.), Deutsches Städtebuch. Handbuch städtischer Geschichte, 5 vols., Stuttgart 1939-1974: vol. 1, Nordostdeutschland (1939); vol. 2, Mitteldeutschland (1942); vol. 3, NordwestDeutschland, vol. 3.1, Niedersachsen/Bremen. Niedersächsisches Städtebuch (1952); vol. 3.2, Westfalen. Westfälisches Städtebuch (1954); vol 3.3, Landschaftsverband Rheinland. Rheinisches Städtebuch (1956); vol. 4, Südwest-Deutschland vol. 4.1, Land Hessen. Hessisches Städtebuch (1957); vol. 4.2.1, Badisches Städtebuch (1959); vol. 4.2.2, Württembergisches Städtebuch (1961); vol. 4.3, Land Rheinland-Pfalz und Saarland. Städtebuch Rheinland-Pfalz und Saarland (1964); vol. 5, Bayern. Bayerisches Städtebuch, vol. 5.1, Unter-, Mittel- und Oberfranken, (1971); vol 5.2, Ober-, Niederbayern, Oberpfalz und Schwaben (1974). Hereafter Deutsches Städtebuch. Handbuch städtischer Geschichte will be cited as "StB: volume number."

A revised version of the Handbuch has been published by the Institute for Comparative Urban History (Institut für vergleichende Städtegeschichte) at the University of Münster, edited by Heinz Stoob und Peter Johanek: vol. 1, Schlesisches Städtebuch, ed. Waldemar Grosch (1995); vol. 2, Städtebuch Brandenburg und Berlin, eds. Evamaria Engel, Lieselotte Enders, Gerd Heinrich and Winfried Schich, with Harald Engler (20oo); vol. 3.2, Städtebuch Hinterpommern, eds. Peter Johanek and Franz-Joseph Post, with Thomas Tippach and Roland Lesniak, 2003. For Austria, cf. Alfred Hoffmann (ed.), Österreichisches Städtebuch, Vienna 1968-1999: vol. 1, Die Städte Oberösterreichs, ed. Herbert Knittler (1968); vol. 2, Die Städte des Burgenlandes, ed. Renõ Deák, 2nd revised ed. (1996); vol. 3, Die Städte Vorarlbergs, ed. Franz Baltzarek and Johannes Pradel (1973); vol. 4, Die Städte Niederösterreichs, 3 subvols., ed. Friederike Goldmann (1976-1988); vol. 5, Die Städte Tirols, 5.1, Bundesland Tirol, 5.2 Südtirol, ed. Franz-Heinz Hye (1980/2001); vol. 6, Die Städte der Steiermark, 2 subvols., ed. Friederike Goldmann (1990/1995); vol. 7, Die Stadt Wien, ed. Peter Csendes and Ferdinand Opll (1999) still to be published are: vol. 6.1, Graz, vol. 6.2, Die Städte der Steiermark: $A-H$; vol. 8, Kärnten.

19 Erich Keyser, "Neue deutsche Städteforschung," in StB:1, 1-10, 3. This introductory essay is primarily a reprint of one of Keyser's essays, "Neue Forschungen zur Geschichte der deutschen Städte," Blätter für deutsche Landesgeschichte 83 (1937), pp. 46-53.

Keyser, "Neue deutsche Städteforschung," p. 1. 
in race research at the Reich Ministry of the Interior. City archivists and local and regional historians provided Keyser with data for a short "biographical" entry for each town or city according to a predetermined rubric. The schematic also included obviously ideologically biased points-for example, point 16, which recorded the city's Jewish population. Point 5 deals with major disasters in the history of the city - in particular, fires and floods - which allows for the database-like organization of this information. This is not the place for a detailed discussion concerning the very problematic roles played by Keyser and many contributors to Nazi ethnic history and to the framework of Ostforschung (an outdated Weimar Republic and National-socialist term for Eastern European research) in general. ${ }^{21}$ For present purposes, we can accept that not all elements of the data and the schematic are steeped in ideology and that the Städtebücher do retain value as an aggregation of source analysis. The definition of "city" underlying the whole enterprise is disputable, as is every definition of the city, but also entirely pragmatic and feasible:

The city book contains the representation of the history of all cities that belonged to the German Empire or to the area comprising the free city of Danzig on January 1, 1936. Under the term "city" we understand here all communities which were, in the past, considered as cities according to historical legal, business, or settlement parameters and which, before the law of January 1, 1936, were officially described as cities, according to city constitution or official designation. It therefore also includes those places that, in the course of time, have lost their status as cities. ${ }^{22}$

21 Willi Oberkrome, Volksgeschichte. Methodische Innovation und völkische Ideologisierung in der deutschen Geschichtswissenschaft (Göttingen: 1993), pp. 32-35, 56-72; Ingo Haar, Historiker im Nationalsozialismus. Die deutsche Geschichtswissenschaft und der Volkstumskampf im Osten, Göttingen 200o, pp. 135-39; Kai Arne Linnemann, Das Erbe der Ostforschung. Zur Rolle Göttingens in der Geschichtswissenschaft der Nachkriegszeit, Paderborn 2002; concerning Keyser in the context of National Socialist Ostforschung (East Studies), see Jörg Hackmann, "Der Kampf um die Weichsel. Die deutsche Ostforschung in Danzig 1918-1945," Zapiski Historyczne 58 (1993), pp. 37-57. On populationist and racial governmentality at the roots of the Ostforschung, see Ingo Haar, "Ostforschung im Nationalsozialismus. Die Genesis der Endlösung aus dem Geiste der Wissenschaften," in Rainer Mackensen (ed.), Bevölkerungslehre und Bevölkerungspolitik im "Dritten Reich," Opladen 2004, pp. 219-40; in particular concerning Keyser, see Alexander Pinwinkler, "Volk, Bevölkerung, Rasse and Raum: Erich Keyser's Ambiguous Concept of a German History of Population, ca. 1918-1955," in Ingo Haar and Michael Fahlbusch (ed.), German Scholars and Ethnic Cleansing, New York 2005, pp. 86-99.

22 StB:1, p. 4, for the concept of the city in more recent literature see Peter Johanek and Franz-Joseph Post (ed.), Vielerlei Städte. Der Stadtbegriff(Cologne: 2004). 
Of course this also includes originally "German" towns and cities, which are no longer located in Germany and may not even exist as distinct cities at all anymore. The attribution of cities in the Städtebücher to a certain region corresponds to twentieth-century political borders. This was a deliberate choice necessary for the purpose of organizing work and fixing spatial boundaries at a given point in time. In most cases relevant to this study, such regional attributions simply served as approximate indicators of geographical location and city and fire distributions (e.g., northwestern, northeastern, southwestern, etc.).

The then unusual nature of the ethnic-historical approach consisted primarily in the inclusion of not only the traditional large imperial cities of Cologne, Augsburg, Nuremberg, Frankfurt, Regensburg, etc., but a multitude of 3,500-4,000 smaller cities, towns, and other communities that together shaped the everyday urban landscape between the Middle Ages and early modern eras. Since they concern the history of the entire "Volk" in structural terms, these "average cities" were accorded a new dignity in relation to the exceptional major cities. This innovation was described as a key contribution to the overall historiographic turn to ethnic history in the 1930 s. ${ }^{23}$ Strikingly, the planned inclusion of small-, micro-, and dwarf municipalities into newer urban historical analysis thus has a hidden root in that early ethnic history. While since the mid-199os the inclusion of smaller municipalities has been once again recognized as important by several researchers in the international community, they tend to think of this as an emulation of the English model of the "small city" approach. ${ }^{24}$ Therefore, just as continuities

23 StB:1, p. 2. Emphasis in original.

24 See the programmatic publications: Peter Clark, Small Towns in Early Modern Europe, Cambridge 1995; Peter Clark, "Small towns 1700-1840," in Peter Clark (ed.), The Cambridge Urban History of Britain, vol. 2, 1540-1840, Cambridge 200o, pp. 733-74; HolgerTh. Gräf (ed.), Kleine Städte im neuzeitlichen Europa, Berlin 1997; Peter Borsay and Lindsay Proudfoot (eds.), Provincial towns in early modern England and Ireland: change, convergence, and divergence, Oxford 2002; Peter Johanek, "Landesherrliche Städte—kleine Städte. Umrisse eines europäischen Phänomens," in Jürgen Treffeisen (ed.), Landesherrliche Städte in Südwestdeutschland, Sigmaringen 1994, pp. 9-25; Klaus Vetter, Zwischen Dorf und Stadt. Die Mediatstädte des kurmärkischen Kreises Lebus, Weimar 1996; Katrin Keller, Kleinstädte in Kursachsen. Wandlungen einer Städtelandschaft zwischen Dreissigjährigem Krieg und Industrialisierung, Vienna 20o1; Christoph Bernhardt (ed.), special issue "Kleine Städte," Informationen zur modernen Stadtgeschichte 2 (1999); Helmut Flachenecker and Rolf Kiessling (eds.), Städtelandschaften in Altbayern, Franken und Schwaben. Studien zum Phänomen der Kleinstädte während des Spätmittelalters und der Frühen Neuzeit, Munich 1999; Thomas Rudert and Hartmut Zückert (eds.), Gemeindeleben. Dörfer und kleine Städte im östlichen Deutschland (16.-18. Jahrhundert), Cologne 2001; Holger Th. Gräf and Katrin Keller (eds.), Städtelandschaft-Réseau urbain-Urban network. Städte im regionalen 
between "ethnic history" and the older structural and social history of the 1950s have been highlighted, it might be wise to recall similar continuities in urban history. ${ }^{25}$ However, it is a simple truth that small towns dominated the landscape, particularly in central Europe, for a very long period of time. ${ }^{26}$ In this respect, continuing the German Städtebücher project and embarking on respective Austrian and Bohemian analogues after World War II, was a logical development.

The entries of the Städtebücher regarding city fires conceal some uncertainties in their scanty descriptions, which have nothing to do with their problematic ideological framing: very often the year alone is given as information ("fires in 1517, 1679, 1843"), though perhaps the original archival records contained more information. Occasionally, statements concerning the severity of the fires, the number of destroyed houses, or the state of reconstruction are added to the entries. If such specifics regarding the severity of the fires are given, the descriptions, which are often based on narrative sources, are often very vague, citing, for example, the destruction of "almost the whole town," "half of the city," or "two-thirds". But these forms of description often have direct roots in the source material, as has been confirmed by other attempts to create fire lists. ${ }^{27}$ The Städtebücher formulated no clear criteria as to which fires were big and significant enough to be recorded under point 5 of the rubric. Because a legion of contributors scattered throughout German archives for decades (at least before World War II) provided this information, a uniform result and homogenous classification cannot be assumed. It therefore seems highly possible that there were very different criteria at work here. ${ }^{28}$ In order to achieve greater precision and accuracy, or at least to be able to qualitatively estimate the probable degree of aberration and difference, in the course of building the

Kontext in Spätmittelalter und Früher Neuzeit, Cologne 2004; further literature with Olaf März, Fließende Übergänge zwischen Stadt und Land. Ein sozial- und wirtschaftsräumlicher Vergleich in Braunschweig-Wolfenbüttel im 18. Jahrhundert, Hannover 2014, pp. 13-18.

25 Cf. Winfried Schulze, Deutsche Geschichtswissenschaft nach 1945, Munich 1989, pp. 281301; Oberkrome, Volksgeschichte.

26 Heinz Schilling, Die Stadt in der Frühen Neuzeit, 2nd ed., Munich 2004, p. 8; Ulrich Rosseaux, Städte in der Frühen Neuzeit, Darmstadt 2006, p. 5 .

27 Jones, Porter, and Turner, Gazetteer, p. 12; Frost and Jones, The Fire Gap, p. 346 n 15; Lilja, Wooden Towns, pp. 273-75; Jutikkala, Great Fires, p. 241.

28 On this point, cf. also Thomas Spohn, "DerStadtbrand als Chance. Wiederaufbauplanungen für westfälische Städte vom 17. bis ins 19. Jahrhundert," in Feuer! Stadtbrand in Westfalen, Münster 1990/1991, pp. 49-72: "The references in Erich Keyser, Westfälisches Städtebuch, Stuttgart 1954, concerning the extent of the destruction are incomplete and imprecise" (note 1$)$. 
database I collected the research of local historians and other accessible urban research—systematically for specific years and unsystematically for the entire dataset. $^{29}$

Combining all the information in the Städtebücher with the further information derived from archival and local history data results in 8,200 fires in 1,964 towns and cities - not all of the 2,315 towns and cities represented in the first edition of the Städtebücher, ${ }^{30}$ nor all of the 371 in the new editions since 1995, or the 259 Austrian towns and cities, include an entry on fire. A simple distribution of the frequency of fires per year for the total dataset from the years 1000 to $1939^{31}$ is presented in the image below (Figure 6). It is evident that the number of fires becomes important only from the 1370s on and that the absolute number of fires dramatically decreases only beginning around 1870. If one were to superimpose (as Frost and Jones do) the rapid urban population growth beginning at the end of the eighteenth century onto this graphic, the striking concentration of fire frequency between around 1820 and 1865 would lose significance in relation to the much larger urban population numbers, so that the beginning of the spread of the "German" or central European fire gap would appear to be located around 1700, increasing steadily until 175 o (Fig. 5) ${ }^{32}$

29 Cf. Spohn, "Der Stadtbrand als Chance", note 1: "The present study is thus based on an (in any case, incomplete) examination of the regional historical literature as well as on materials that were collected by the author and others at the Westphalian office for monument conservation".

$30 \quad$ StB:5.2, p. 8.

31 The time frame stopping in 1939 suggests that the destruction of cities through the bombing of World War II took on new dimensions in an epochal sense that are not comparable with earlier findings.

32 The data for the city fires comes from my database just described; the graph for the growth of German urban population (in 10.000) in the 64 largest cities is drawn according to the numbers well known as gathered by J. de Vries, European Urbanization 1500-180o, London 1984, Appendix I, 281-282, 287 and rendered by Schilling, Die Stadt, pp. 11-12. The graph claims not to represent precise data (as did and could not the original graph by Jones/ Porter). It does not suggest that there is a mathematical relationship between both values. Likewise, in Frost/Jones' original fire gap graphs, the graphs and data of the urban population were likewise just superimposed over the graphs of the number of burnt houses per year, but using the same scale on the left side does not mean that both numbers are parts of a mathematical function: the 'fire gap' pictures are therefore just a form to illustrate the fact that more and more people of a country live in cities, that cities grow immensely, but that, apparently the danger of very large conflagrations decreases at the same time at least in those cultural contexts and on average. 


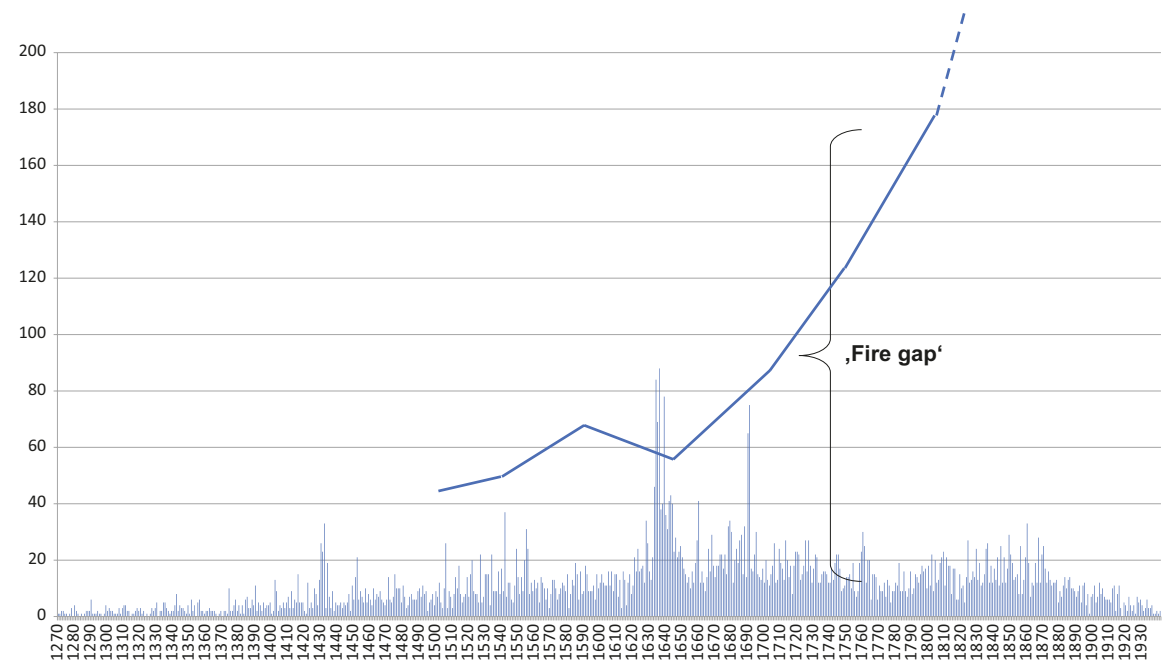

FIGURE 5 The 'Central-European fire gap': Big fires in Germany 1270-1939 and growth of the urban population in Germany (in the largest 64 cities, by 10,00o people)

The frequent peaks in the graph are predominantly war induced. Single years with values of thirty fires or more from the Hussite Wars (1428-30), the Landshut War of Succession (1504), the Second Margrave War (1553), the Thirty Years' War (1626-48) - including the record years of 1632 (84 fires), 1634 (88 fires), and 1637 (78 fires) - the First Northern War (1657-58), the SwedishBrandenburg War (1676-78), the Nine Years' War (War of the Palatine Succession) (1688/89 and 1693), and the beginning of the Seven Years' War (1758) are all easily recognizable as caused by war-related activities. In the eighteenth century, however, fires were relatively scarce even during wartime (Revolutionary and Napoleonic wars), which is a clear indicator that war tactics had changed from infrastructure destruction to decisive battle plans. The exceptionally high fire frequencies in $1540,1666,1684,1686,1847,1858$, and 1868, however, are not explainable by wars-a topic which will be further addressed below. It will be useful to construct a regionally differentiated analysis, especially when accounting for the war-induced peak values, for reasons that go beyond simply addressing fire counts for the whole dataset. ${ }^{33}$ In this case, it

33 Due to the shifting of national and administrative borders after 1945 and changes in the relevant state/country borders on which the new series of Städtebücher draws, there are overlaps and omissions (several cities appear twice, others are no longer defined as "German"), which should be recognized, but are not of such great importance that they would lead to real inaccuracies for the issue of fire characteristics in a given physical/ geographic region. 


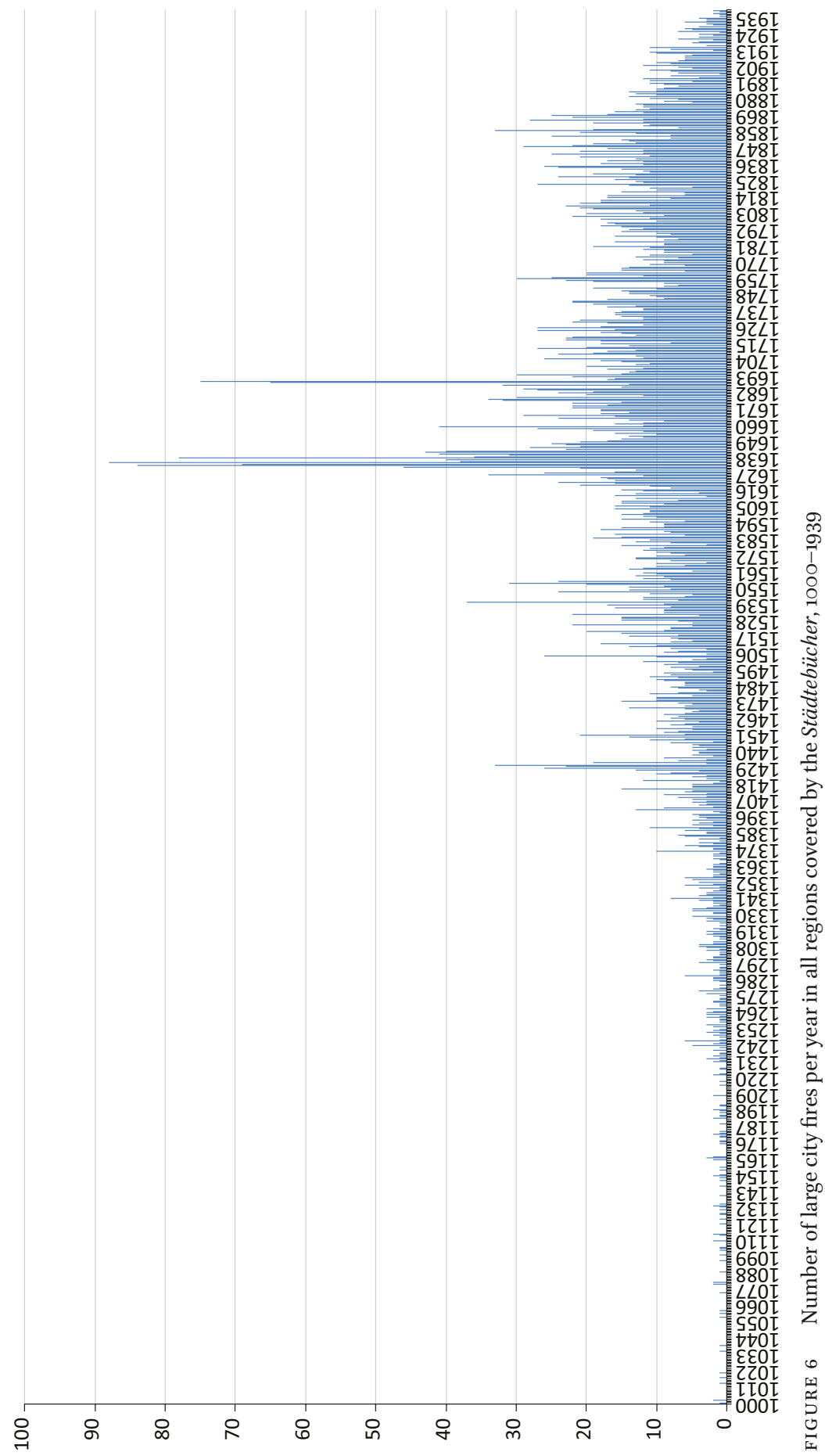


is apparent that merging the data to create a fire statistic for all of Germany has relatively little meaning, because the respective averages and peak values are still strongly specific and different for each region. A comparison of fire frequency distributions demonstrates that it makes sense to group certain regions ${ }^{34}$-namely Baden, Rhineland, Rhineland-Palatinate and Saarland (Figure 7); Württemberg (Figure 8), Bavaria (Figure 9), Hesse, Westphalia and Lower Saxony-excluding the coastal regions of Lower Saxony (Figure 10); Saxony, Saxony-Anhalt, and Thuringia (Figure 11); Schleswig-Holstein, Mecklenburg, Pomerania, East Pomerania, and (with some exceptions because, particularly in the late Middle Ages, a very unique fire characteristic is still present) East Prussia as a Baltic state (Figure 12); Brandenburg and Berlin (Figure 13); Silesia (Figure 14), Austria (Figure 15). The selected starting year for these statistics reflected the degree of urbanization of the specific regions. For the Southwest, even for very early years, a substantial number of fires were documented, simply because there were already many early urban communities in this region. The datasets for the North and East have respectively later starting points.

Further, more sophisticated consideration of the urban fire phenomenon associated with individual wars is made possible by such regional distribution analysis: in East Prussia, the so-called "Hunger War," the Polish invasion of the Prince-Bishopric of Warmia in 1414, and the Knights' War of 1519-21 can all be considered war events that caused solitary series of city fires. For Baltic Schleswig and Holstein, Mecklenburg, and Pomerania, the Thirty Years' Warexcept for 1630, the year that Sweden entered the war-appears to be much less important than the years $1656-59,1676 / 77,1688,1696$, and 1719-36, correlating with the Northern Wars, the Swedish-Brandenburg War, and the War of Polish Succession; in later years, only the years 1759 (of the Seven Years' War) and 1807 (of the Napoleonic Wars) distinguish themselves. While the Hussite Wars had no effect in the Northeast, Brandenburg (1432), and especially Saxony, Saxony-Anhalt, Thuringia (1429/30), and Bavaria (1430) were hit hard. In the latter regions, the Saxon Brother War culminated in 1450 with a devastating onslaught of city fires; the Hildesheim Abbey Feud of 1519 was also destructive in this sense. In Saxony, Saxony-Anhalt, Thuringia and Hesse, as well as Brandenburg, the Thirty Years' War years of 1621, 1626, 1631/32, 1636/37, 1641/42 comprise the pinnacles of destruction for these regions. Silesia was only affected

34 According to the modern distribution of the Städtebücher, which of course do not adequately represent the historical territories during the time of the Holy Roman Empire. However, for the purpose of fire statistics, such an approximate regional categorization is sufficient. 
in the years $1627,1633 / 34$ and 1642 , and Bavaria was only affected in 1631-35 and-less intensively - in 1639-41. The western regions of Baden, Rhineland, Rhineland-Palatinate, and Saarland, were repeatedly hit by fire during the years 1631-47; however, truly destructive peaks representing at least ten major fires per year were not recorded. 1678, 1681, 1684, 1707, 1709, 1711, 1717, and 1719 are very fiery years in Saxony, Saxony-Anhalt, and Thuringia (ten or more fires per year) - the fires were, however, obviously not related to war in these yearsand thereafter it is only the year of the Napoleonic military expedition in 1806 that stands out. The Nine Years' War caused a year of blazing cities in Baden, Rhineland, and the Palatinate in 1688, but did not have this effect until 1693 in Württemberg. The Seven Years' War, viewed in terms of the fires it triggered, is actually of minor significance in Brandenburg (1757/58) and Pomerania (1759). The Bavarian region is influenced by some only regionally important fire-filled wars - the Cities' War (1388), the First Margrave War (1449, 1553), as well as the Landshut War of Succession (1504), and the War of the Austrian Succession (1743). Other wars that were only influential on a local level included the Feud of Soest (1447) and the Cologne War (1583).

In 1,511 cases, the number of houses destroyed by each respective fire was directly given or otherwise deducible from information either in the Städtebücher or from other local historical sources. ${ }^{35}$ In total, there were 145,881 destroyed houses with an average of about 96 houses per fire, with fires ranging from very small to large, and including a few very large fires in Hamburg (1684: 1,714 destroyed houses; 1842: 4,200), Altendresden (1,900), and Aachen (4,600). Basing the size categorization for fires on the number of destroyed houses, the overall characteristics thus differ significantly from the English analysis by Jones, Porter and Turner (Table 1$):{ }^{36}$

While for England it would seem that the number of fires with a small number of destroyed houses (10-49) clearly outweighs the following categories (the ratios for the first six categories of 10-299 houses are 100: 27: 19.6: 9: 1.5: 1.5), for central Europe there is much less spread in the ratios (100: 64: 36: 20: 9:5). This means that-assuming the English numbers are reliable—in the case of central Europe, the frequency of major fires is much higher. From dividing the

35 In cases where the percentage of destruction was given and where information about the number of houses in the city at the time of the fire was available, I have calculated that number by dissolving the ratio. Since the proportions are given in vague forms such as "half the city/one third of the city burnt," no emphasis is laid on the real accuracy of the absolute numbers, but the degree of precision should be enough for evaluating the general proportions. 
TABLE 1 Number of fires/number of destroyed houses.

Left: Numbers for central Europe. Right: Numbers for England ${ }^{a}$

Houses Number of Fires
Destroyed

Houses Number of Fires
Destroyed

\begin{tabular}{lr}
$10-49$ & 546 \\
$5^{\circ}-99$ & 347 \\
$100-149$ & 198 \\
$150-199$ & 108 \\
$200-249$ & 53 \\
$250-299$ & 28 \\
$300-349$ & 35 \\
$35^{\circ}-399$ & 11 \\
$400-449$ & 6 \\
$45^{\circ}-499$ & 0 \\
$500-549$ & 0 \\
$55^{\circ}-599$ & 0 \\
$600-649$ & 2 \\
$65^{\circ}-699$ & 0 \\
$700-749$ & 2 \\
\hline
\end{tabular}

\begin{tabular}{lr}
\hline $10-49$ & 66 \\
$50-99$ & 18 \\
$100-149$ & 13 \\
$150-199$ & 6 \\
$200-249$ & 1 \\
$250-299$ & 1 \\
$300-349$ & 1 \\
$350-399$ & 0 \\
$400-449$ & 0 \\
$45^{\circ}-499$ & 1 \\
$500-549$ & 0 \\
$55^{\circ}-599$ & 0 \\
$600-649$ & 2 \\
\hline
\end{tabular}

a The latter dates are from Jones, Porter, and Turner, Gazetteer, p. 5.

relevant number of destroyed houses by the total number of fires (and accepting the inherent imprecision of this), ${ }^{37}$ we can conclude that the most likely number of houses that burned down in a typical fire is ten for central Europe.

The fact that the highest probability is ten houses, rather than a lower number, reflects the fact that the data sources primarily concern major fires. ${ }^{38}$ However, at the core of these findings the fact remains that the premodern

37 Thus, by replacing the data points of an imagined graph of the number of cases of a given number of houses burnt down with the mean of the surrounding ten points. In this case, each of the disproportionately common 10o- and 10-step levels can be explained on the basis of the fact that they seem to only arise in the Städtebücher and other information because the values are always fixed at round numbers (e.g., "1o houses, 100 houses, 200 houses destroyed"). A graphical representation of the resulting curve is not given, but would essentially comprise a high peak around the value 10 and a rapidly logarithmically falling curve for all higher values.

38 The countless small and isolated fires involving less than ten houses are typically not included in the Städtebücher at all. The value thus corresponds to a certain degree of 
danger of city fires consistently focused on major conflagrations rather than on isolatable single fires. The data in this regard are the same for both wartime and peacetime fires-interestingly, in comparison to the ratios in the database as a whole, war-induced fires are significantly underrepresented by a factor of two. This likely reflects the fact that the entries detailing the numbers of houses were usually based on the administrative efforts of the magistrate or other official authorities - of course, the functioning of the responsible municipal management, especially in times of war, was often completely ineffectual. In any case, no statistically significant differences in the destructive effects of normal versus war-related fires can be ascertained.

Since the distribution is strongly asymmetrical, the most probable number of houses destroyed per fire is not equal to the average number of houses destroyed, which, as previously mentioned, is 96 . This average value of 96 therefore indicates very little, and the variance-i.e., the width of distributionis very high. Even if one removes the eleven exceptionally major fires which burned more than 700 houses, the variance value is still 112 houses. This value is also a measure for the uncertainty with which the size of each particular fire could have been predicted - a measure of uncertainty that may have been of interest to fire insurers, but was not accessible to them in early modern times. Today, an insurer might ask the question about what was the most probable size of a fire, and one can answer it retrospectively of a fire: while approximately 40 per cent of all fires destroyed between 3 and 48 houses, about 70 per cent of all fires in the area destroyed between 3 and 100 houses. This demonstrates that a remarkably high proportion of fires were relatively large (i.e., affecting between 49-100 houses).

In the attempt to model the relationship between the number of destroyed houses per fire with a proximity function, another value from the data can be derived, from which the normal size of a "city" can be estimated at between 280 and 380 houses. ${ }^{39}$ This illustrates the extent to which the problem concerns small and tiny towns. By including this information, the numbers given above concerning the probable size of fires becomes that much more remarkable -in relation to these tiny communities, the given numbers indicate almost complete destruction of the town in many of these cases. Because the 1,511 documented cases concern, for the most part, smaller damages and the given number of cases represents approximately 18 per cent of the total

self-referentiality, since the more than one thousand contributers to the Städtebücher and the further primary and secondary sources integrated here have implicitly defined a major, noteworthy fire as one that destroyed at least ten houses.

The approximation formula for the number of fires would be $f$ times $x$ burned houses: $f(x)=A^{*} x /\left(1+x^{2} / D^{2} t_{a}^{2}\right){ }^{*} \exp (-x / G)$, with the total value of $A=2.9$ fires, the range Delta $=10-14$ houses as the most probable size of fire. 
number, these findings may be taken as representative for the total scope of city fires.

For all regions and for the total dataset it becomes clear that the fire gap for the German-speaking area begins to expand around 1700. One of the most important military developments of this time was the trend away from the wars of siege and devastation characterizing the late Middle Ages and the seventeenth century toward combat wars and greater military professionalism and discipline. While this demanded great resources from cities for quartering soldiers, among other things, the trend no longer aimed at the complete destruction of towns and cities (see section 4 below).

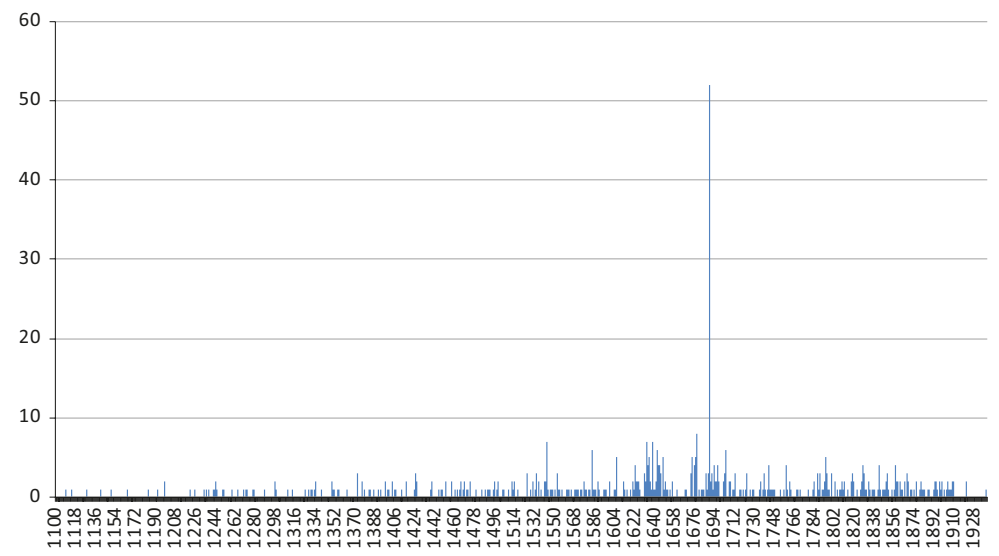

FIGURE 7 Baden, Rhineland, Rhineland-Palatinate, Saarland 110o-1939

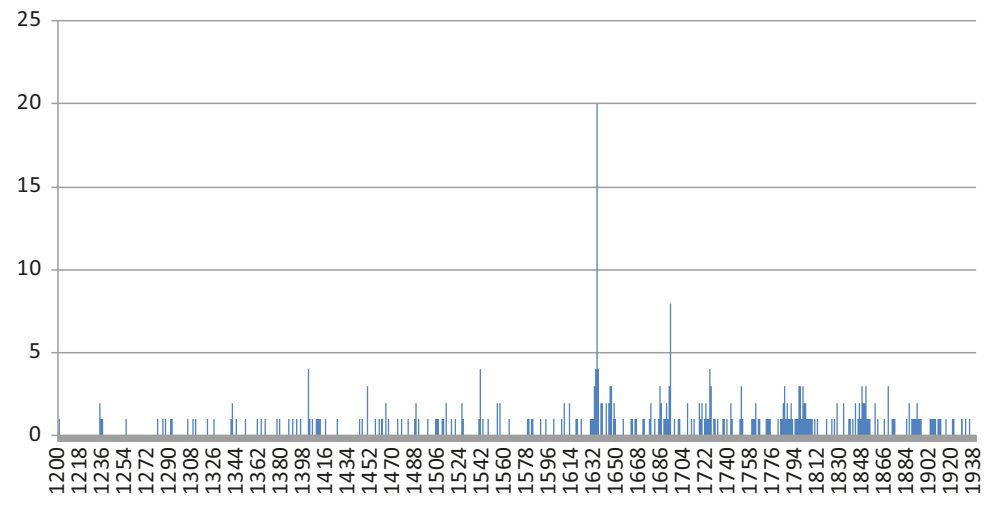

FIGURE 8 Württemberg, 1200-1939 


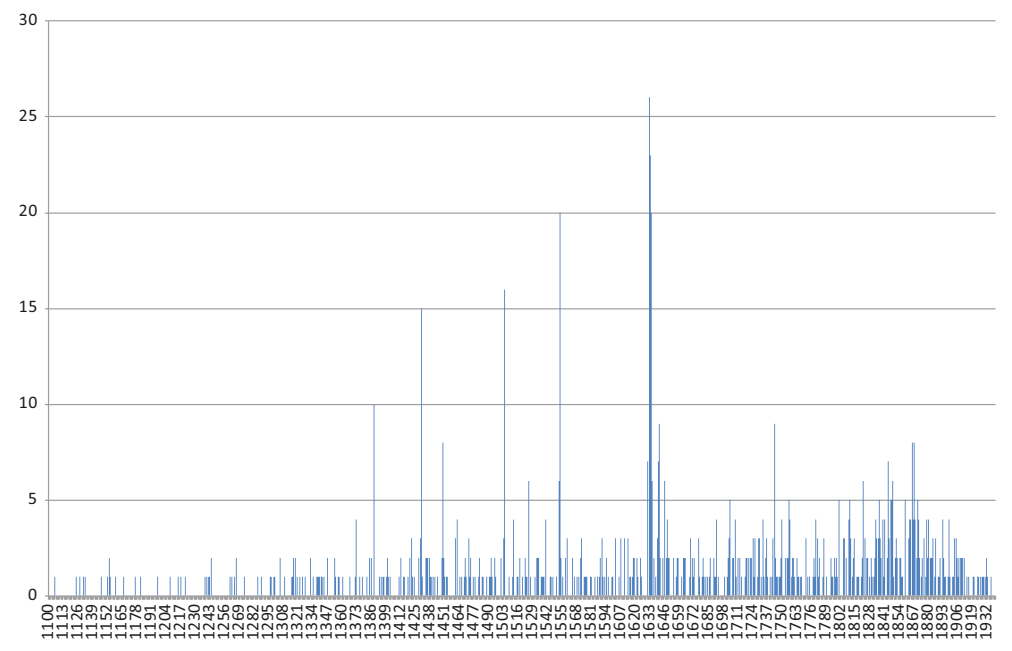

FIGURE 9 Bavaria 1100-1939

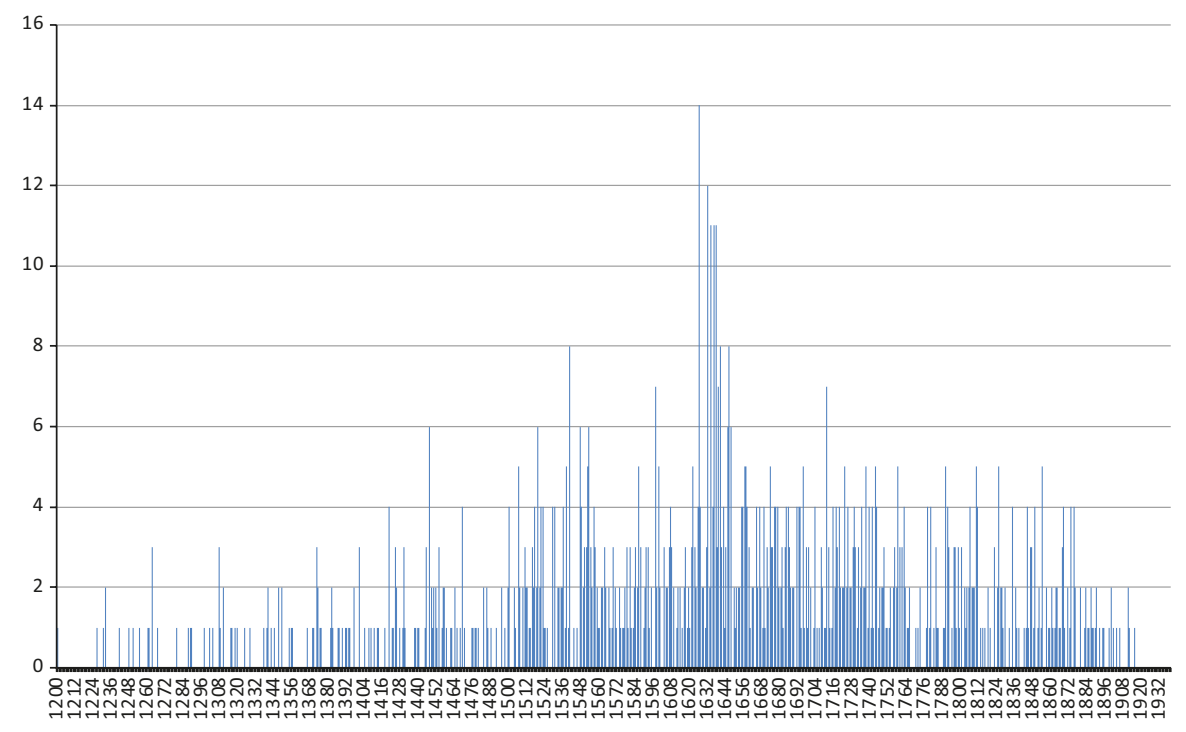

FIGURE 10 Hesse, Lower Saxony, Wesphalia, 1200-1939 


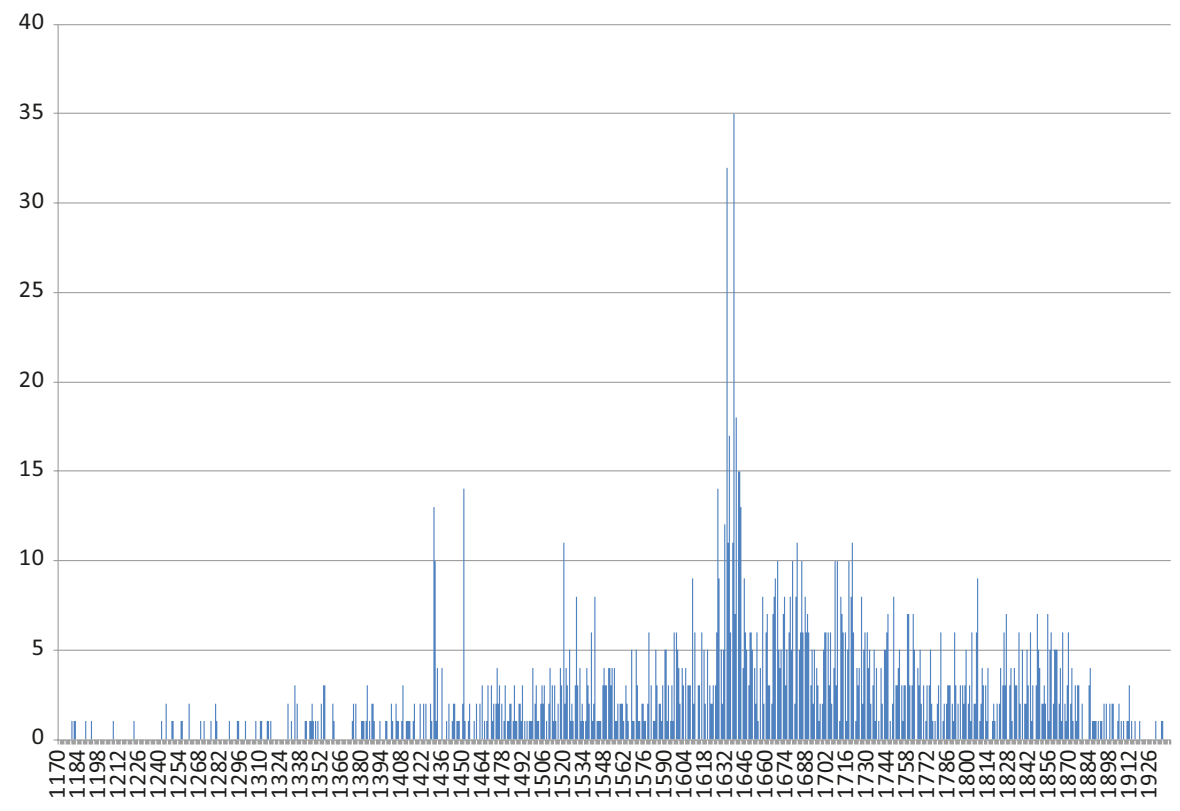

FIGURE 11 Saxony, Saxony-Anhalt, Thuringia, 1170-1939

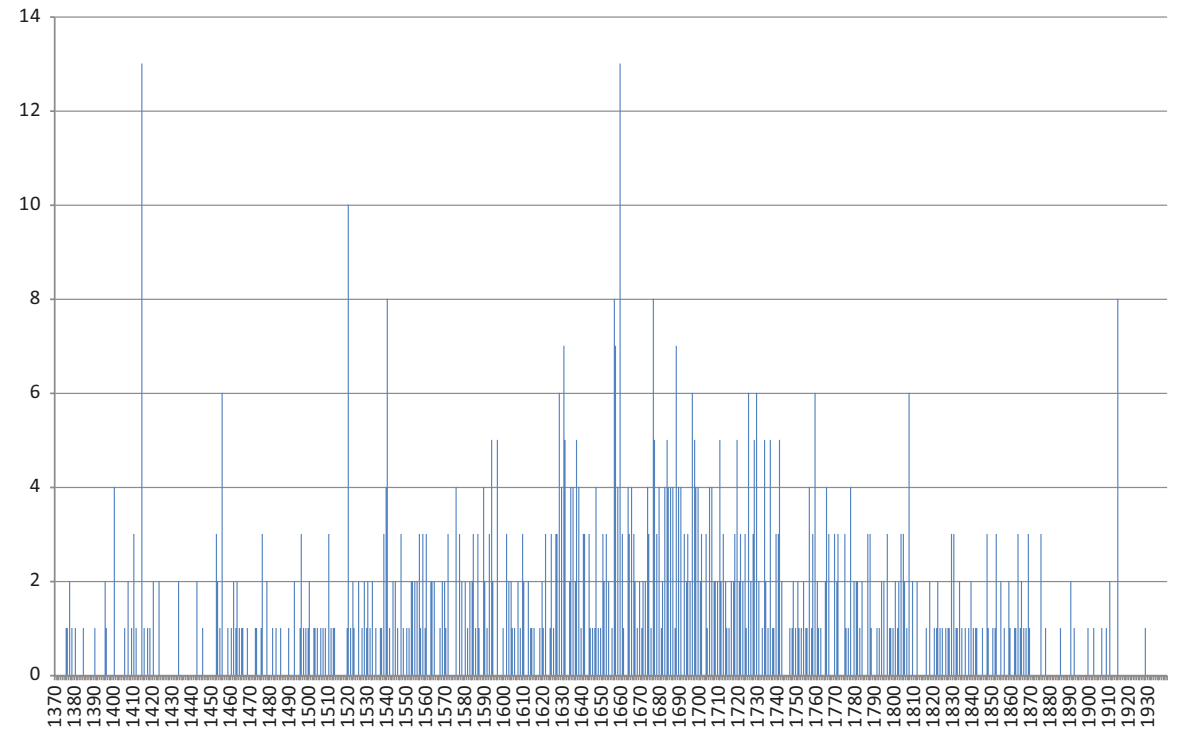

FIgURE 12 Schleswig-Holstein, Mecklenburg, Western and Eastern Pomerania, East Prussia, 1370-1939 


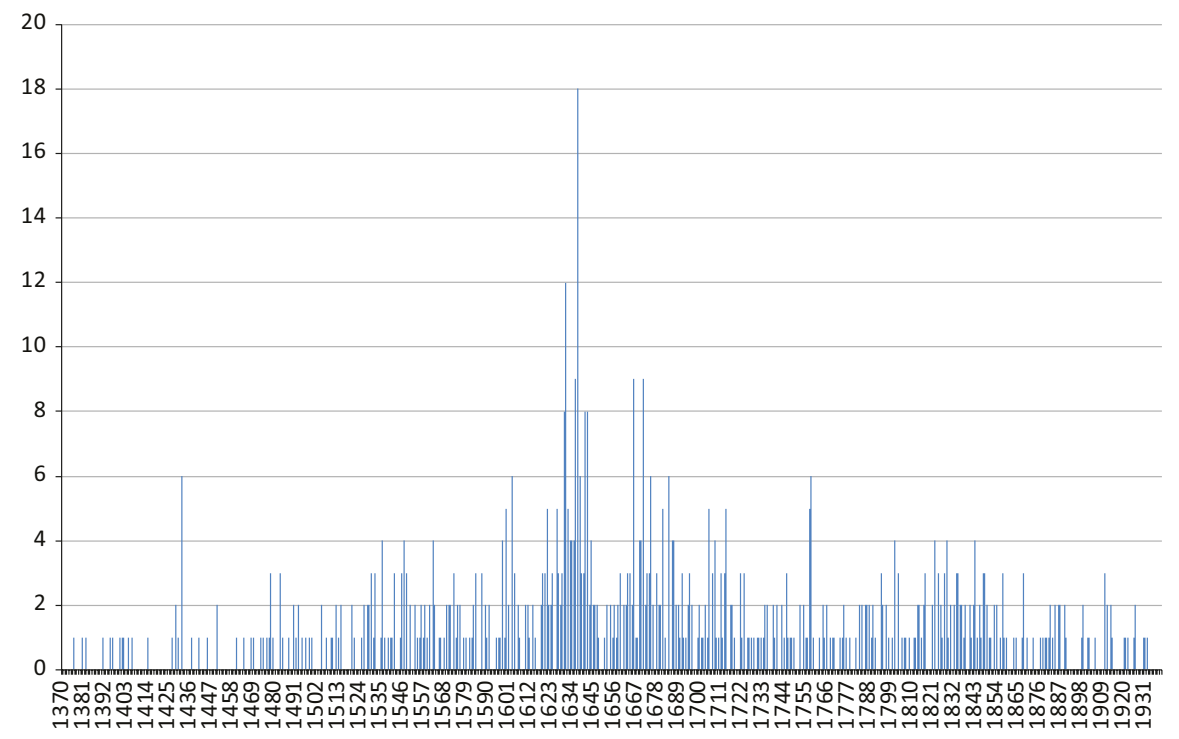

FIGURE 13 Brandenburg and Berlin 1370-1939

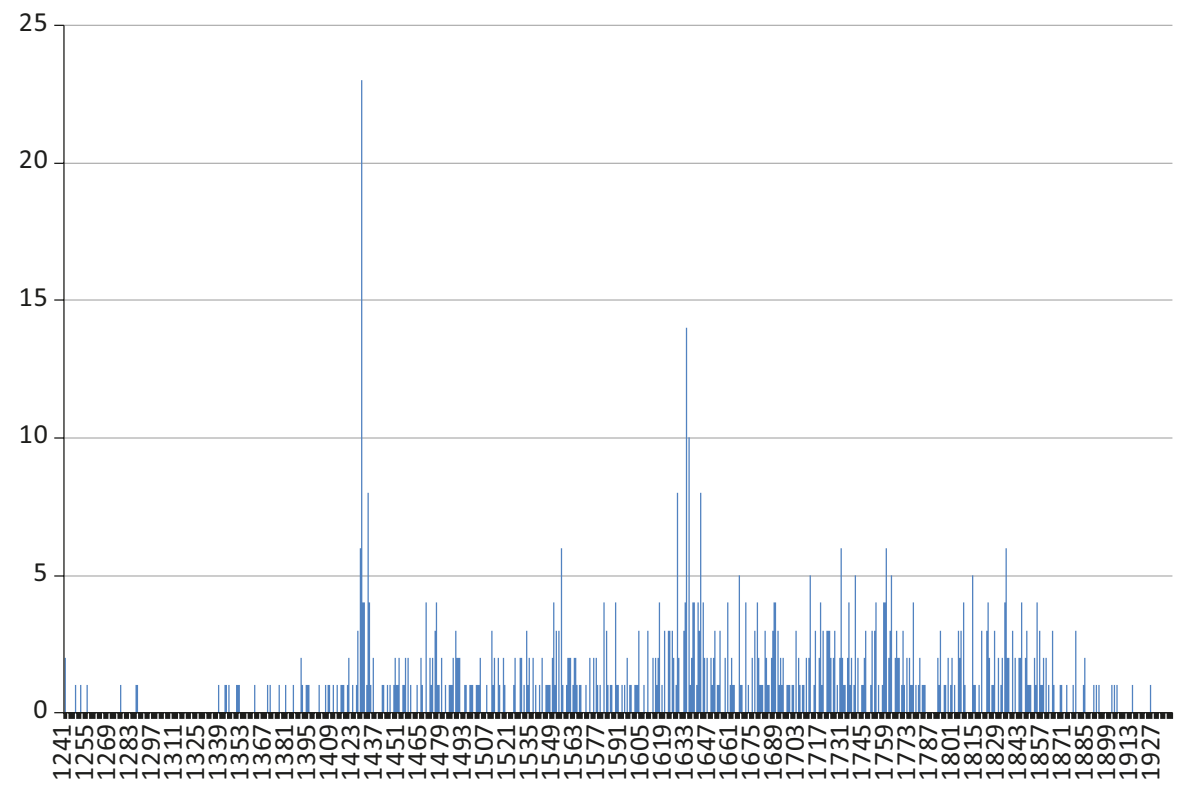

FIGURE 14 Silesia, 1240-1939 


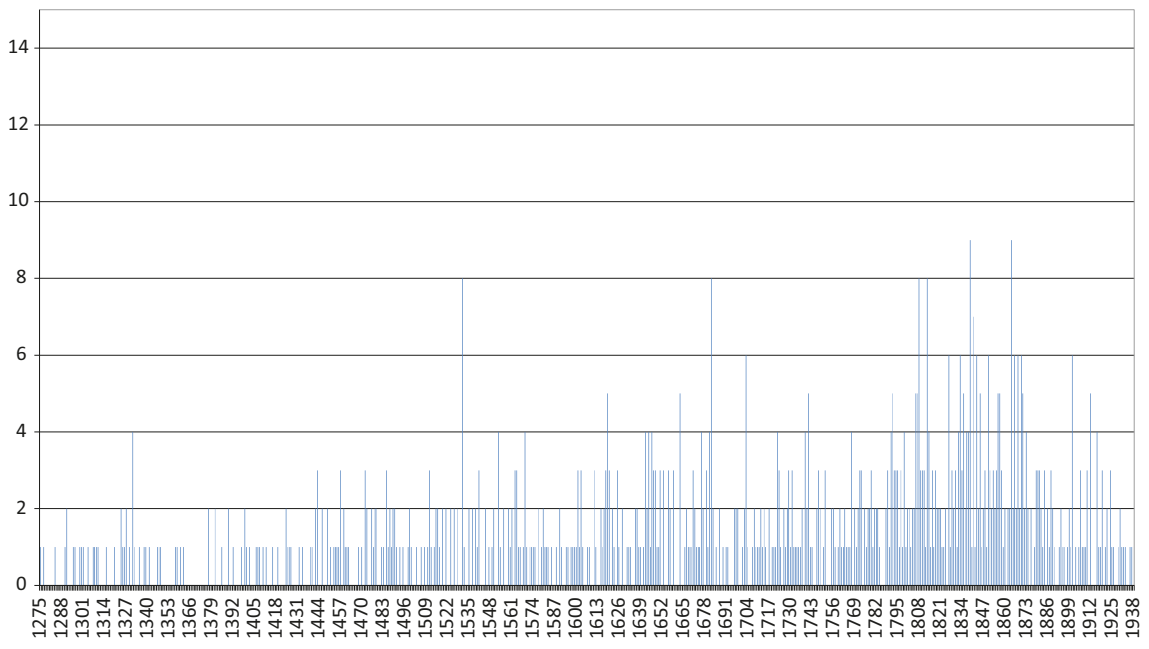

FIGURE 15 Austrian Städtebücher 1275-1939

\subsection{Trends in Fire Frequencies According to Fire Insurance Statistics}

Only a grainy image of Germany's urban fire ecology emerges through the analysis of the Städtebücher. To develop a more detailed image and reveal the finer details in the picture of annual fire damage in a region, there is hardly a more productive premodern source than the records of fire insurance institutions themselves. However, this does greatly limit the targeted time period and regions, since the establishment of such insurance and the relevant archival transmission is a prerequisite. In this context, the Middle Ages become inaccessible. Of course, it should be noted that there are a few substantive local analyses for earlier time periods. Gerhard Fouquet demonstrates that only 63 fire events were responded to in Basel between 1445 and 1549, and that a single major fire in April 1495 destroyed 40 houses - for a Swiss town of some importance with a substantial portion of the town built in stone, these are hardly dramatic findings, but it shows that for some rare cities we might still find similar data for medieval times. ${ }^{40}$ The statistics assembled by Peter Borscheid and Anette Drees reveal twenty-four territorial or municipal fire insurance organizations with values recorded before $1800,{ }^{41}$ the most important being those

40 Gerhard Fouquet, Bauen für die Stadt. Finanzen, Organisation und Arbeit in kommunalen Baubetrieben des Spätmittelalters. Eine vergleichende Studie vornehmlich zwischen den Städten Basel und Marburg, Cologne 1999, pp. 414-20. Thomas Spohn, "Zur Einleitung," in Thomas Spohn (ed.), Bauen nach Vorschrift? Obrigkeitliche Einflussnahme auf das Bauen und Wohnen in Nordwestdeutschland, 14.-20. Jh., Münster 2002, pp. 1-68, judges this as the single experiment with quantitative calculation thus far. Borscheid and Drees, Versicherungsstatistik. 
of Baden-Durlach/Baden, Braunschweig, Hamburg, Hesse-Darmstadt, HesseKassel, Calenberg-Grubenhagen, Lippe, East Prussia (i.e., Königsberg and that for the so-called "small towns" [Kleinstädtische]), Saxony, and Württemberg. Of course, not all cameralistic fire insurance funds existing in Germany before 1800 are represented within this source, ${ }^{42}$ and the data is somewhat incomplete even for those addressed by Borscheid/Drees. Nevertheless, the data does offer a more detailed picture of the fire trends in the individual regions associated with each institution, not only concerning the evolution of insurance amounts-i.e., the usually continuous growth in the value of insured building stock — but also by noting the actual yearly amount of fire damages paid. Of course, due to the state of record preservation complicated by centuries of intense territorial and administrative diversification within Germany, historical economic valuations of buildings and documentation related to urban building trends are scarce, while in Great Britain, data regarding building cycles is more easily accessible. Therefore, Pearson could compare the economic development of insurance with building trends and thereby relatively plausibly deduce when a construction boom also created an increase in insurance numbers - simply because there was an increase in the building stock that could be insured-or when there was intrinsic growth in the insurance business that was unrelated to such external factors. ${ }^{43}$

The interrelation between damage payments and the value of, for the most part, relatively continuously rising insurance amounts primarily demonstrates only that the rise of damage payments on average is, of course, based only on the proportions given here (generally, a higher number of insured buildings also leads to increased damages). It is important to pay attention to the peaks in certain years with unusually high damage payments. Do they indicate a very large city fire or a multitude of smaller fires? Do they correlate with simultaneous peaks in German fire ecology?44 This can be determined by comparing regional fire insurance data with the database of the Städtebücher. A major city fire always causes a substantial peak in the data-it is potentially but not necessarily related to a general climatic situation. Therefore, such years should be excluded when evaluating a climate correlation, unless other data confirms that the spike should be interpreted as a result of climate influence. If fire

42 A good discussion of the small scale of many territorial institutions, and also of the limited nature of surviving sources concerning those small territories, which make a true historical statistical accounting impossible, is offered by Spies, Feuerversicherung, pp. 253-272. Cf. appendix 2 below for the major portion of fire insurance foundings in the German territories until the early nineteenth century.

43 Pearson, Insuring the Industrial Revolution, pp. 38-46.

44 The concept of "fire ecology" is used here in reference to Stephen Pyne's concept of "fire ecology"; it could be defined as the broad overview and analysis of the fire cycles and fire threats inherent to a given regional city environment. 
damages in a region are widely distributed, without a major city fire identified as the primary cause, then the probability of a climatic induction is very high. Continuously dry conditions, unusually hot and dry months, scant rainfall before a fire, and strong winds at the moment the fire begins have always been conditions that significantly increase the effect of fires.

In particular, this comparative analysis results in the following conclusions: in Baden, the years $183^{2}$ and 1849 seem to stand out, but there are no unusual events for those years recorded in the Baden Städtebuch; the peak values in these years could have been caused by a large number of fires scattered throughout the region. In Bavaria, in contrast, the peak in the fire insurance statistics does correlate with the data derived from other city records: the year 1822, with a significant number of six large fires, including Marktredwitz (30 destroyed houses and 36 barns), ${ }^{45}$ Deggendorf (92 houses), and SulzbachRosenberg ( 281 houses); the year 1834 (three major city fires in Wunsiedel [205 houses], Weilheim, and, most significantly Bad Reichenhall, in which threequarters of the city was destroyed), 1848 (four major town fires: Eibelstadt, Kemnath [103 houses], Pleystein [55 houses], Selach, Windischeschenbach [6o houses]) and 1850 (two town fires in Bischofsheim [137 houses] and Grafenau). The Braunschweig statistics (Figure 16) show high peaks in 1780 (Goslar city fire), ${ }^{46} 1794$ (fire in Altenau, upper Harz), 1823 (Büddenstedt fire: 34 farms, 73,049 Reichstaler (Rtl.) in damages), 1825 (Seesen city fire: 6o houses, 142 outbuildings, 104,187 Rtl. in damages); the peaks in 1816, 1834, and 1836 are, however, not explainable by any major singular city fires in the Duchy of Braunschweig. The Calenberg-Grubenhagen Fire Insurance Fund, which later belonged to the Electorate of Braunschweig-Lüneburg, then later to the Kingdom of Hanover, exhibits swings that are comparable with the Städtebücher data: 1824/25 (Elze fire, 1824), 1826/27 (Einbeck fire, 1826), 1834/35 (Dransfeld and Rethem fires), $1844 / 45$ (Clausthal-Zellerfeld fire). The peaks of $1796 / 97$ and 1831/32, however, appear somewhat inscrutable. The Hesse (Hesse-Darmstadt) Chamber of Fire Insurance lists peaks in 1797, 1799, and 1803 (explainable by the impact of the revolutionary wars in rural areas), 1834, 1842-44, and 1848-53, which cannot be clearly explained via coincidental events in the Städtebücher database; the

45 Oskar Gebhardt, Abriss der Geschichte und Topographie von Markt-Redwitz [...], MarktRedwitz 1906, p. $69 f$.

46 The more or less free imperial city of Goslar applied for inclusion in the Braunschweig insurance fund in 1768 , was admitted in 1771 and was expelled again after the destructive fire of 1780 , the damages of which were, however, still thoroughly compensated by the fund, see Braunschweigische Landesbrandversicherungsanstalt (ed.), Festschrift 225 Jahre LBVA. Braunschweigische Landesbrandversicherungsanstalt 1754-1979, Braunschweig 1979, p. $16 f$. 
peaks in 1810 (Beerfelden fire), and 1825 (Offenbach and Michelstadt fires), however, can be explained in this way. In the case of the Nassau Fire Insurance Fund, the years $1819,1825,1827,1843$, and ${ }_{1848}-50$ are peak years. In this case, there is nothing more than a fire in Haiger (1827) that relates to these numbers. For the Saxon State Insurance Funds (Sächsische Landesbrandversicherungsanstalt), the Wars of Liberation are reflected in 1814/15, and 1832 was a year of plentiful city fires (Hainichen, Waldheim, and Schellenberg/Augustusburg), while 1843 bears the consequences of the Oschatz and Sayda fires of 1842. The Waldeck-Pyrmont Insurance Fund records a completely typical development of over almost 6o years without major incidences; the large peaks in 1843/44, 1847, and 1849 are, however, hardly explainable through city fires (only the Sachsenberg fire of 1844 is relevant here). The major fires in Göppingen (1782), Wangen (1793), Tuttlingen (1803), and Balingen (1809) are easily discernable in the statistics of the Württemberg Fire Fund (Figure 17). The peaks after 1844 are, however, more difficult to explain as the result of major city fires (although there were smaller fires in Ebingen, Grötzingen, Trossingen, Oberriexingen, Dornhan, Schömberg, Veringenstadt, and Tettnang during this period). The East Frisian Rural Fire Insurance Fund (Die ostfriesische Feuerversicherungskasse des platten Landes; Figure 18) had the advantage of covering only rural areas absent any larger cities. This unusual feature makes it clear that the significant spikes in 1815,1825 , and 1834 are an indication of unusual climatic events, since they concern regionally scattered conditions that are not distorted by major solitary city fires.

For almost all statistical groups, the years $1824 / 25$ and 1834 , in addition to the 1840 os and 185 os, feature disproportionately high peaks: the peaks in the latter years suggest that the effects of protoindustrial development—as analyzed below (in Ch. 3, 1.6) using Hamburg as an example-are not isolated effects, but that the fire risk definitively rose in these years. In relative terms, this absolute increase was not dramatic - taking into account the population increase and the fire hazards related to the protoindustrial means of production. In absolute terms, however, it was significant.

The analysis of fire ecology characteristics on this mesolevel, therefore, illustrates times of low and high fire frequencies on a local-regional level. One might take the peaks of such periods with high fire frequency therefore also to represent the strong "stress factor" that this great threat was representing for the urban (and rural) population in premodern societies-a stress factor often neglected in manuals and syntheses devoted to the early modern era. This stress factor can be detailed, when the sources allow, even more precisely at the city or regional microlevels (cf. Ch. 3, 1.6). Two causal factors for outbreaks of city fires were clearly war and climate. 


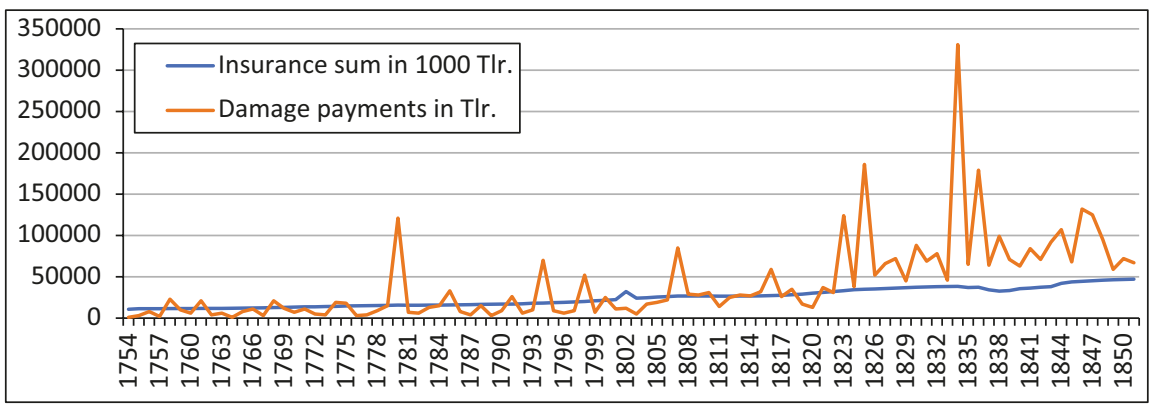

FIGURE 16 Braunschweig Landesbrandversicherungsanstalt (Braunschweig Territorial Fire Insurance) $1754-185^{\circ}$

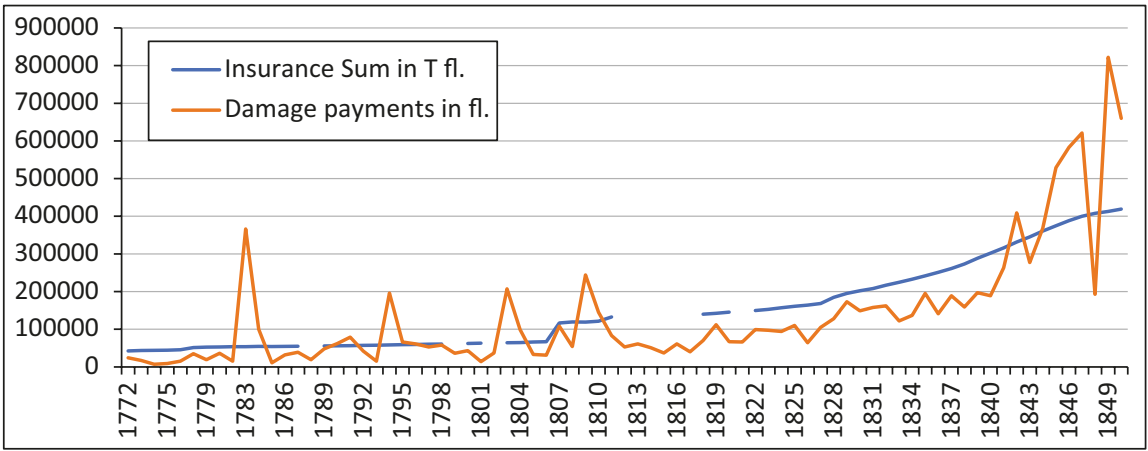

FIGURE 17 Württemberg Gebäudebrandversicherung (Württemberg Building Insurance) $1772-1850$

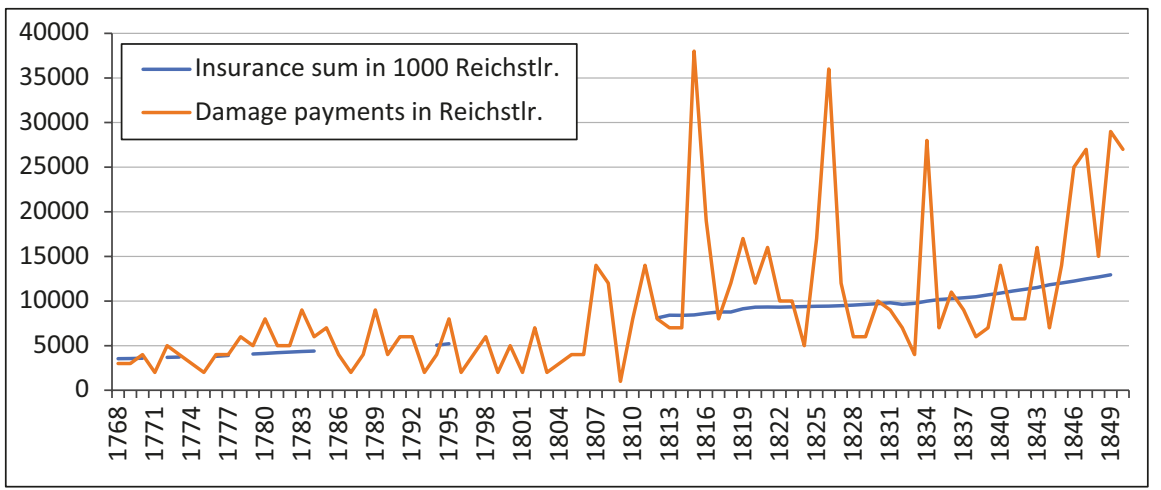

FIGURE 18 Ostfriesische Feuerversicherungskasse des platten Landes (East Frisian Rural Fire Insurance Fund) 1768-1850 


\subsection{War and Fire Trends}

In German city fire statistics taken as a whole, decisive war years are always clearly visible; the Hussite Wars, the Thirty Years' War and the Nine Years' War comprise the highlights of the entire list. The 250 years between 1430 and 1700 form the high-point of fire danger in the German-speaking realm, at precisely the time of the much-discussed "military revolution." This suggests that this critical war-fire boom could also be correlated with other European regions.

At first glance, it is not surprising to find that 1634, a single year during the Thirty Years' War, was the most important fire year in Germany as a whole, according to the available fire data, since it is this year, in particular, that was hit by a random cumulative effect, even though there are many other years that seem more important in regional historical memory. This can be easily ascertained through a comparison of statistics for Germany as a whole with specific regions. In Silesia, fires were more prevalent in 1633; in Bavaria they were more prevalent in 1632 and 1633, after Sweden's entry into the war; in southwestern Germany, 1633; in Brandenburg, 1631 and 1637; in Saxony, Saxony-Anhalt, and Thuringia, 1632, 1637, and 1639; in Hesse, Westphalia, and Lower Saxony, 1626 and 1632; in northern Germany, 1630. Only Württemberg reflects this singular peak during the Thirty Years' War: 1634, with 20 city fires. The high peak value of nearly 90 city fires in 1634, never before and never again reached in the nearly 1,00o recorded years, is therefore a cumulative value. This value signifies that while 1634 was not the regional peak year for the destruction and pillaging of the Thirty Years' War (other than in Württemberg), there were never again so many major destructive fires in so many areas during the same year. ${ }^{47}$

47 In Baden: Elzach, Hornberg, Schönau; Bayern: Aichach, Bad Tölz, Ebersberg, Eichstätt, Erding, Freising, Furth i. Wald, Fürth, Göggingen, Kronach, Landshut, Lichtenberg, Mainburg, Pleystein, Roding, Schnaittenbach, Schönsee, Stadtsteinach, Velden, Wassertrüdingen. In Brandenburg: Gartz/Oder, Kyritz, Liebenwalde, Lieberose; Hessen: Büdingen, Gelnhausen, Grüningen, Reinheim, Runkel, Windecken. In Farther Pomerania: Bahn, Pyritz; Mecklenburg: Teterow. In Lower Austria: Melk. In Lower Saxony: Clausthal, Dransfeld. In East Prussia: Kreuzburg. In Rhineland: Düsseldorf. In RheinlandPfalz: Bingen. In Saxony: Bautzen, Dippoldiswalde, Kirchberg/Zwickau, Sayda, Wilsdruff, Zschopau. In Saxony-Anhalt: Klötze, Sömmerda, Suhl, Wolmirstedt. In Silesia: Glatz, Greiffenberg, Hirschberg, Lauban, Leobschütz, Liegnitz, Muskau, Neustädtel, Ohlau, Patschkau. In Thuringia: Creuzburg/Werra, Kaltennordheim, Rastenberg, Themar. In Westphalia: Medebach, Olpe. In Württemberg: Aalen, Calw, Friedrichshafen, Giengen/Br., Grötzingen, Heimsheim, Heubach, Laichingen, Lorch, Metzingen, Neuffen, Plochingen, Schorndorf, Steinheim/Murr, Stuttgart-Feuerbach, Stuttgart-Zuffenhausen, Trossingen, Tuttlingen, Waiblingen. 
A few of the recorded city fires for 1634 were, however, not war inducedthe Olpe fire of 1634 , caused by the carelessness of blacksmiths, completely incinerated the town, with the exception of the Felmicke area; ${ }^{48}$ the fire of Liebenwalde (the so-called "Dancers' " or "Betzen" fire of April 16, 1634);49 the small fire in Buxtehude during the imperial occupation; ${ }^{50}$ the ClausthalZellerfeld fire of September 20, 1634 (destroyed 162 houses, as well the city hall, archives, and the market church); ${ }^{51}$ and the Düsseldorf fire of 1634 , caused by lightning striking the gunpowder tower. In contrast, the fires in Bavaria set by Sweden in the spring and summer of 1634 were clearly war induced: Matthias Merian's Theatrum Europaeum documents over 700 burned towns and cities in this region. ${ }^{52}$ This number may be highly exaggerated, but without a doubt, the number of communities affected by fire in 1634 was much larger than the number of go known fires recorded in the Städtebücher according to given archival sources: one must keep in mind that only communities with town charters are included in the data, while the large number of villages is excluded by definition - though the size of the communities was often similar. Local histories note a few details about the 1634 fires in Aichach (June 24);33 Pleystein, ${ }^{54}$ a fire, which like the Bautzen fire, was caused by setting the suburbs on fire by the Austrian Colonel Goltz; ${ }^{55}$

48 Asta Schröder, “Die Stadt Olpe," in Josef Wermert (ed.), Olpe. Geschichte von Stadt und Land. vol. 1, Von den Anfängen bis zum Ende des Ersten Weltkrieges, Olpe 2002, pp. 219-62, 229.

49 Jörn Lehmann, Die Stadt Liebenwalde. Ein Streifzug durch die Geschichte der Ortsteile Freienhagen, Hammer, Kreuzbruch, Liebenthal, Liebenwalde und Neuholland, Karwe 2004, p. 103 .

$50 \quad$ Michael Mattern, "Die Stadtbefestigung Buxtehudes im 17. Jahrhundert und ihr Bild in den schwedischen Festungsplänen," Heimatliches Buxtehude 5 (1997), pp. 115-29.

$5^{1} \quad$ Heinrich Morich, "Die früheren Brandkatastrophen in Clausthal und Zellerfeld," in 450 Jahre Clausthal-Zellerfeld 1532-1982, Clausthal-Zellerfeld 1982, pp. 74-76, 75 .

52 Johann Nepomuk Sepp, Die Kriegsthaten der Isarwinkler, Munich 1874, p. 59f. Henricus Oraeus, Theatri Europaei Oder Historischer Chronicken Beschreibung Aller Vornembsten vnd Denckwürdigsten Geschichten, so sich hin vnd wieder in Europa, sonderlich im Reich Teutscher Nation von Ao. 1633 biß in Ao. 1638 begeben vnd zugetragen, part 3, first published by Matthäus Merian, Frankfurt am Main 1670 .

53 Konrad Danhauser, Topographische Geschichte der Stadt Aichach und ihrer Umgebung, Munich 1858, p. 12 f.

54 Colonel Corpus entered the city with 300 cavalrymen and set the city on fire, destroying most of it, including the city hall, hospital, and the city hall archives: Siegfried Poblotzki, Geschichte der Herrschaft, der Stadt und der Pfarrei Pleystein, Pleystein 1980, p. 14of.

55 KarlLimmer,Entwurfeinerurkundlich-pragmatischen Geschichte der Lausitzen, Ronneburg 1839, p. 235; cf. Rudolf Wolkan, "Studien zur Reformationsgeschichte Nordböhmens," Jahrbuch der Gesellschaft für die Geschichte des Protestantismus in Österreich 4, 2 (1883), pp. 67-95, 8of. 
as well as a wealth of fires set by the swarming imperial army after the battle of Nördlingen, ${ }^{56}$ i.e., those in Giengen/Brenz (May 9), Aalen (July 9), ${ }^{57}$ Waiblingen (September 18), ${ }^{58}$ Heimsheim, Neuffen, Schorndorf, 59 and also Fürth/Bavaria. ${ }^{60}$

The spread of the fire gap after about 1700 also strongly relates to the fact that the number of war-induced fires apparently decreased consistently due to changes in military techniques. Military history no longer characterizes the eighteenth century as an era of outright peace, but rather emphasizes that even during the Enlightenment, war and the military played a significant role. Jeremy Black has repeatedly pointed out that in the discussion about the "military revolution," the developments of the eighteenth century have been severely neglected. ${ }^{61}$ The wars of the eighteenth century cannot be viewed as simply more harmless and less cruel than the wars of the seventeenth century; even if it were possible to definitively establish a specific decrease in frequency in view of the longue durée, this would be offset by the increase in intensity related to the ever-increasing size of armies. ${ }^{62}$ Nonetheless, the fire statistics seem to clearly prove, rather re-revisionistically, that the character of wars had changed. Whether it is possible to ascertain the establishment of standing armies with successful social disciplining of the military corps is anyone's guess. ${ }^{63}$

56 Gerd Zillhardt, Der Dreißigjährige Krieg in zeitgenössischer Darstellung. Hans Heberles "Zeytregister" (1618-1672). Aufzeichnungen aus dem Ulmer Territorium, Ulm 1975, p. 151.

57 Bernhard Hildebrand, "Aalen im Jahre 1634. Der große Stadtbrand und seine Ursachen," Aalener Jahrbuch (1982), pp. 67-81; Bernhard Hildebrand "Die Ereignisse um 1634. Im allgemeinen und unter besonderer Berücksichtigung der Schlacht bei Nördlingen und des Schicksals der Stadt Aalen," Nordschwaben. Zeitschrift für Landschaft, Geschichte, Kultur und Zeitgeschehen 12, 3 (1984), pp. 123-31, 13of.: the city was supposedly set on fire by the brothers Johann and Jesaias Nietner, who set the gun powder stores on fire.

$5^{8}$ Gottfried Lammert, Geschichte der Seuchen, Hungers- und Kriegsnoth zur Zeit des Dreissigjährigen Krieges, Wiesbaden 189o, p. 179.

59 Gustaf Roeder, Württemberg. Vom Neckar zur Donau. Landschaft, Geschichte, Kultur, Kunst, Nuremberg 1972, pp. 191, 314, 438.

6o Georg Tobias Christoph Fronmüller, Chronik der Stadt Fürth, 2nd ed., Fürth 1887, p. 96.

61 Jeremy Black, A Military Revolution? Military Change and European Society, 1550-1800, Basingstoke 1991; Jeremy Black, European Warfare, 1660-1815, London 1994; Jeremy Black, "A Military Revolution? A 166o-1792 Perspective," in Clifford J. Rogers (ed.), The Military Revolution Debate, Readings on the Military Transformation of Early Modern Europe, Boulder 1995, pp. 95-114.

62 Johannes Burkhardt, "Die Friedlosigkeit der frühen Neuzeit. Grundlegung einer Theorie der Bellizität Europas," Zeitschrift für historische Forschung 24, 4 (1997), pp. 509-74.

63 Cf. Ralf Pröve, Stehendes Heer und städtische Gesellschaft im 18. Jahrhundert. Göttingen und seine Militärbevölkerung 1713-1756, Munich 1995; Jürgen Luh, Kriegskunst in Europa 1650-180o, Cologne 2004. 
However, the professionalization of the army, the new recruitment and quartering practices, the logistical innovations concerning the organization of army supplies (étapes), and the martial-law ban on outright pillaging and raids outside of the logics of a formal "contribution system" corresponding to a military state created new conditions.

While the old theory of the increasing militarization of society is supported in this respect, since the military was a consistent presence and a part of society in everyday urban life, ${ }^{64}$ it is conversely true that the separation between the military and society was much more precisely defined and adhered to. ${ }^{65}$ For the state of the war itself, this necessitated a shift toward fortress sieges and decisive battles in the context of relatively regulated occupation politics, in contrast with the uncontrolled practice of mercenary warfare, the burning of cities as an act of revenge during the Thirty Years' War, and the rationalistic, thoroughly organized scorched-earth warfare practices employed, for example, in the Nine Years' War by Louis XIV. ${ }^{66}$ These are, however, only trends, for which one can always find counterexamples. In pointing out this tendency, one should also mention that the catastrophic town-destroying military logic of the seventeenth century was, in terms of fire history and aggregate serial town destruction, only exceeded by the bombing campaign of the Second World War. Looking at these exceptional periods standing together in an unholy alliance, it becomes clear why, in the collective memory of cities and towns (through guidebooks, chronicles, monuments, etc.) the destruction of the Thirty Years' War, (especially concerning the last major city fire), and the destruction of the Second World War are often mentioned in the same breath. This doubling of two wide-ranging series of urban destruction is certainly worthy of a collective

64 Concerning this topic see Peter H. Wilson, "Social Militarization in Eighteenth-Century Germany," German History 18 (2000), pp. 1-39.

65 For a summary of the research see Daniel Hohrath, "Spätbarocke Kriegspraxis und aufgeklärte Kriegswissenschaften. Neue Forschungen und Perspektiven zu Krieg und Militär im 'Zeitalter der Aufklärung," Aufklärung 12 (2000), pp. 5-47, where it is suggested that, regarding the wars of the eighteenth century in particular, "very little has been published in recent times" (14). Cf. also Marian Füssel, Der Siebenjährige Krieg. Ein Weltkrieg im 18. Jahrhundert, Munich 2010.

66 Horst Carl, Okkupation und Regionalismus. Die preußischen Westprovinzen im Siebenjährigen Krieg, Mainz 1993, pp. 10-17; Colin Jones, "The Military Revolution and the Professionalisation of the French Army under the Ancien Régime," in Rogers, The Military Revolution Debate, pp. 149-67, 164; Roland Vetter, "Die ganze Stadt ist abgebrannt." Heidelbergs zweite Zerstörung im Pfälzischen Erbfolgekrieg 1693, Karlsruhe 2009; Emilie Dosquet, "Die Verwüstung der Pfalz als (Medien-)Ereignis. Von der rheinländischen Kriegshandlung zum europäischen Skandal," in Krieg und Kriegserfahrung im Westen des Reiches 1568-1714, ed. Andreas Rutz, Göttingen 2017, pp. 333-370. 
memory study and, to a certain extent, might be considered a truly unique property of the German collective disaster memory on a European and global level. ${ }^{67}$

Stephen Pyne, the American historian who dared to devote almost his entire ouvre to fire and has founded an almost distinct field of fire history, has focused almost exclusively on the history of rural fire management regimes. In his account of the history of fire in Europe, city fires appear only cursorily, ${ }^{68}$ and there is no discussion of the relationship between fire and war. Similarly, Johan Goudsblom's history of civilization essay devotes not a single word to the development of warfare in relation to fires. ${ }^{69}$ This is all the more surprising because of the fact that premodern warfare was very obviously the main producer of major city fire disasters. It seems that the unconscious influence of the well-known Romantic nature/culture distinction is at play here, so that fire disasters, inflicted by people on people, drop out of the perspective of fire ecology-in direct opposition to the methodological caveat that was long ago articulated by researchers such as Martin Melosi and William Cronon. But just as environmental history in general has increasingly included urban spaces within its purview, when it comes to the material flow and metabolic relationships between the town and its surroundings (Melosi), from a macroperspective, even this secular conjuncture of the relationship between war and the city fire as a relevant topic of environmental history must be grafted into fire history. The partial taming of war in this regard from 1700 until the firebombing campaign of World War II is a historically unlikely phenomenon that is central to an epochal threshold in fire history-one which will be explicated as a central point of investigation further below.

67 The topic of how the National Socialist image of history often referred to the "Thirty Years' War" as a tragically fated chain of events reflecting its own, contemporary notion of "total war" is certainly relevant in this context, cf. Laurenz Müller, Diktatur und Revolution. Reformation und Bauernkrieg in der Geschichtsschreibung des "Dritten Reiches" und der DDR, Stuttgart 2004; Mathias Lehmann, Der Dreißigjährige Krieg im Musiktheater während der NS-Zeit [...], Hamburg 2004. This also includes the metaphors and images that were resurrected when, after the British bomber attack on Hamburg in 1942, "Operation Gomorrah" reinvoked the Biblical references also present in the early modern sermons on divine retribution. For recent contributions to this field see Fabian Lampart et al. (eds.), Der Zweite Dreißigjährige Krieg. Deutungskämpfe in der Literatur der Moderne, Baden-Baden 2019.

68 Stephan Pyne, Vestal Fire: An Environmental History, Told through Fire, of Europe and Europe's Encounter with the World, Seattle 1997, pp. 50-59.

69 Johann Goudsblom, Die Entdeckung des Feuers, Frankfurt am Main 1995, pp. 175-183. 


\subsection{Climate and Fire Trends}

Because of the current relevance of the topics of climate change and global warming, climate history has, not surprisingly, increasingly shifted from a mostly neglected, marginal problem of general historical interest, to an absolutely central problem in the postwar era. Inquiries into whether the reality and nature of correlations, or even causal relationships, between the historical climate changes of the last 1,00o years and social developments can be determined, or at least assumed with good reason, are becoming increasingly important.

The basic phases and elements of the climatic evolution of this time period are now well-known, and have been subject to a globally focused and highly specific analysis during the last fifteen years in particular. After $\mathrm{Hu}-$ bert Lamb's 1965 study, which elevated the Medieval Warm Period (Medieval Climate Optimum) - occurring from about 900-1000 AD and then again from 1200-1300 AD - to a leading topic in recent climate-historical interest, the critical inquiries of Malcolm K. Hughes and Henry F. Diaz in 1994 found that this climatic anomaly applied not only to Europe, but that its validity (with phase shifts, in part) could be demonstrated globally. ${ }^{70}$ Likewise, the existence of the second large climatic anomaly of the millennium, the Little Ice Age, is indisputable, and though it was originally discovered as a period of glacier growth on the basis of existing Swiss glaciers, its global reach has also been documented. ${ }^{71}$ However, historical research still has a long way to go in

70 Hubert H. Lamb, "The Early Medieval Warm Epoch and Its Sequel," Palaeogeography, Palaeoclimatology, Palaeoecology 1 (1965), pp. 13-37; Malcolm K. Hughes and Henry F. Diaz, "Was There a 'Medieval Warm Period,' and If So, Where and When?," Climatic Change 26 (1994), pp. 109-42; also cf. the contributions from Zhang De'er, Jean M. Grove/ Roy Switsur, Ricardo Villalba, Kenneth Lee Petersen in the same volume, pp. 143-69, 18397, 243-69; Scott Stine, "On the Medieval Climatic Anomaly," Current Anthropology 41, 4 (2000), pp. 627f.; Keith R. Briffa, "Annual Climate Variability in the Holocene. Interpreting the Message of Ancient Trees," Quaternary Science Reviews 19 (2000), pp. 87-105; B.G. Hunt, "The Medieval Warm Period, the Little Ice Age and Simulated Climatic Variability," Climate Dynamics 27 (2006), pp. 677-94; Samuli Helama, Jouko Meriläinen, and Heikki Tuomenvirta, "Multicentennial Megadrought in Northern Europe Coincided with a Global El Niño-Southern Oscillation Drought Pattern during the Medieval Climate Anomaly," Geology 37, 2 (2009), pp. 175-78; Michael G. Loso, "Summer Temperatures during the Medieval Warm Period and Little Ice Age Inferred from Varved Proglacial Lake Sediments in Southern Alaska," Journal of Palaeolimnology 41 (2009), pp. 117-28. The standard reconstruction of Michael Mann et al. (first 1998, then 2008) for the climate of the last millenium has been remodeled by Robert Tardif et al., "Last Millennium Reanalysis with an expanded proxy database and seasonal proxy modeling", Climate of the Past 15 (2019), pp. 1251-1273.

71 Cf. Jean M. Grove, The Little Ice Age, London 1988; for a virtual reader of 'classic papers' addressing the LIA cf. Frank M Chambers, "The 'Little Ice Age", The Holocene 26, 3 (2016), pp. 335-337. Raphael Neukom et al., "No evidence for globally coherent warm and cold 
terms of the application of these climatological findings, and it is indeed possible that there is an ultimately unbridgeable gap preventing the creation of absolutely valid narratives of causal history in this field. The idea that Gothic cathedrals with their large windows - in contrast to Romanesque buildingscould be interpreted as an architectural-stylistic adaptation to the new warm medieval climate seems to be a rather weak association. ${ }^{72}$ The extent to which the spread of the plague was enabled by the dawning of the Little Ice Age, and whether (or how precisely) the European witch hunts, certain observations concerning suicide statistics, or specific trends in the discourse of melancholy can be best understood in terms of a causal relationship with climatic phenomena, must be further examined, though causal narratives of this kind are already proliferating in large numbers, emerging from the most reputable research institutes and the best academic presses. ${ }^{73}$

However, at least in some cases, it should certainly be possible to draw reliable and statistically plausible correlations between fire trends and annual climatic fluctuations, but this requires sufficient data and statistical evidence. The clearest case in the applicable data sample is the year 1540 , which is known in climate history generally as one of the largest anomalies of heat and dryness in the past 500 years: "Extreme warmth and unusual dryness" prevailed. "For several weeks on end, it hardly rained at all; according to source statements, in 26 weeks there were 'sprinkles' on only five days. The heat of the summer of 1540 is the best-documented event of the sixteenth century and can be viewed

periods over the preindustrial Common Era", Nature 571 (2019), pp. 550-554 argue that, after having shown the global character of both anomalies within the last 1000 years, one needs to stress that those climate epochs were not at all synchronic and coherent for all regions and the continent.

72 "In contrast, the new Gothic style features light and lightness. With its large windows it lets the sunlight of the Medieval Warm Period into the monumental cathedral that were being constructed" (Wolfgang Behringer, Kulturgeschichte des Klimas. Von der Eiszeit bis zur globalen Erwärmung, Munich 2007, p. 109; similarly, Rüdiger Glaser, Klimageschichte Mitteleuropas. 1200 Jahre Wetter, Klima, Katastrophen, Darmstadt 2008, p. 59f.)

73 As a point of entry, see Wolfgang Behringer (ed.), Kulturelle Konsequenzen der "Kleinen Eiszeit", Göttingen 2005; Gillen d'Arcy Wood, Tambora. The eruption that changed the World, Princeton 2014; Sam White, The Climate of Rebellion in the Early Modern Ottoman Empire, Cambridge 2011. For a somewhat critical reponse to Behringer's theories see Emmanuel Le Roy Ladurie, Histoire humaine et comparée du climat, vol. 1, Canicules et glaciers, XIIIe-XVIIIe siècles, Paris 2006, pp. 280-91; for some reminders concerning the learnings from (post-)Popperian discussions about the general problem of historical explanative narratives Cornel Zwierlein, "Klimageschichte und Kulturgeschichte der Frühen Neuzeit. Zum Problem des interdisziplinären Dialogs," in Philip Ajouri, Katja Mellmann, and Christoph Rauen (eds.), Empirie in der Literaturwissenschaft, Münster 2013, pp. 331-51. 
as one of the major events of the millennium.."74 In fact, the Städtebücher clearly identify 1540 as the year with the highest number of town fires (33) without a major war incident in 1540. From the Middle Ages until the nineteenth century this value was only exceeded by the most active phase of the Thirty Years' War (1631-41) and in 1658 and 1688/89:1540, therefore, is not only memorable as the year of the "millennium wine," but also as one of the most catastrophic years in terms of fire danger in the urban history of central Europe. Individual fires are recorded for Stettin Altdamm, Arnswalde, Biesenthal, Dippoldiswalde, Greußen, Husum, Marktredwitz, Neustettin, Nordhausen, Nossen, (July 22), ${ }^{75}$ Pausa, Stettin-Pölitz, Sonthofen, Stargard, Triptis, Velburg, Wangen, Wehlau, Weiden, Wolkenstein, Bingen, Erkelenz, Freudenberg, Hadamar, Herbstein (September 8), ${ }^{76}$ Jever, Peckelsheim, Rhoden, Vörden, Tübingen, Leutkirch, Einbeck and Großenhain. One can presume that the real numbers are actually slightly higher, especially if the unknown number of countless village fires were added. Fires were also documented in Memel (Lithuania) and Regensberg (Switzerland), and the landmark of the town of Greiz, the Oberschloss, also burned in $1540 .{ }^{77}$ However, 1540 is also known in research as the "Mordbrenner" year (the "murder-burner" year, i.e., the arsonists' year): as the Protestant/Catholic confrontation neared a climax, Duke Heinrich the Younger of Braunschweig-Wolfenbüttel, in particular, was accused of employing arsonists to burn several Protestant cities, more or less as acts of guerilla warfare. So which interpretation of fire frequency is therefore correct?

The Einbeck town fire on or about July 26,1540 , which destroyed the whole town and (according to different statements) cost the lives of between 100

74 Glaser, Klimageschichte Mitteleuropas, p. 108; Christian Pfister, Wetternachhersage. 500 Jahre Klimavariationen und Naturkatastrophen (1496-1995), Bern 1999, pp. 191-93; Oliver Wetter et al., "The year-long unprecedented European heat and drought of 1540 - a worst case," Climatic change 125 (2014), pp. 349-63; Oliver Wetter and Christian Pfister, "An underestimated record breaking event—-why summer 1540 was likely warmer than 2003," Climate of the Past 9 (2013), pp. 41-56; Christian Pfister, "The 'Black Swan' of 1540: Aspects of a European Megadrought," in Claus Leggewie and Franz Mauelshagen (eds.), Climate and Culture, Climate Change and Cultural Transition in Europe, Leiden 2018, pp. 156-194.

75 Alfred Berger, Ein Streifzug durch die Nossener Geschichte zur 10oo-Jahrfeier der Landschaft, 750-Jahrfeier des Ortes und 100-Jahrfeier der Einführung der Städteordnung. Gedenkschrift zum Heimat- und Schulfest Pfingsten 1936, Nossen 1936, p. 38: determined to have started spontaneously after a long, major period of heat and drought.

76 Rudolf Bald and A. Dollberger, 70o Jahre Stadtrecht Herbstein. Geschichte und Entwicklung einer Stadt, Lauterbach/Hessen 1962, p. 35: no mention of arson.

77 Manfred Gläser (ed.), Lübecker Kolloquium zur Stadtarchäologie im Hanseraum, vol. 1, Stand, Aufgaben und Perspektiven, Lübeck 1997, p. 309; Alvin Jaeggli-Leepin, Burgen und Schlösser in der Schweiz. Nach alten Vorlagen, Frankfurt am Main 1962, p. 127. 
and 500 people was supposedly one of these arson events-subsequent reconstruction created today's unique cityscape of a completely preserved late Gothic half-timbered town. On July 28, an intoxicated shepherd from Hohenbüchen was arrested, and confessed-admittedly under torture- that the patrician Heinrich Dieck paid him for the arson. ${ }^{78}$ Dieck himself, administrator (Vogt) of Claus von Mandelsloh of Hohenbüchen in the principality of Braunschweig-Wolfenbüttel, was arrested and tortured. In turn, he testified in the interrogation log of September 4, 1540, that Heinrich the Younger commissioned him; he had been hired, in exchange for money, by Klaus von Oberg and Heinrich's head of mercenaries, Christoph von Wrisberg. Whether these statements corresponded to the truth is uncertain -in any case, Dieck was executed. ${ }^{79}$ The fires in Pausa/Vogtland (July 27), Triptis in Thuringia (July 26), Nordhausen (August 11), ${ }^{80}$ Hadamar (March 14), ${ }^{81}$ and Erfurt are all counted among those fires caused by arson. Arson plans were foiled in Kassel, Göttingen, ${ }^{82}$ Braunschweig, Halberstadt, and Magdeburg. ${ }^{83}$ This information, however, relies on statements acquired through torture of the accused or actual offenders. In the case of the fire of Sulza (today Bad Sulza), there was initially uncertainty about the causes, but when hay burnings also occurred in Jena, the elector acted:

After the tiny Sulza, located in our administration district of Roßlau, burned down completely during the last lent (March 2) and it was impossible to understand and recognize if the fire started somehow by accident or if it was due to arson, and as in the following week of Judica (April 3-9)

78 Otto A. Ellisen, "Einbeck im 16. Jahrhundert," Zeitschrift des Harz-Vereins 27 (1894), pp. 549-6o.

79 Andreas Heege, Einbeck 1540. Brandstiftung! Der Einbecker Stadbrand vom 26. Juli 1540. Archäologischer Befund und politische Hintergründe, Einbeck 2005, p. 34.

80 It was also believed that the fires were started through arson in the neighboring city of Mühlhausen: "Wyr haben got erbarms den grossenn verterblichenn brandtschadenn kumer und elende So E.L. auch dernn selbigenn Burgerre und Inwonerre am vergangem mittewochenn durch bosse leutte Zcugefugt, mit bekemmertem und betrubtem gemotthe angehort, und ist uns das got weys hertzlich leidt, unnd wustenn wyr E. L. sampt E. L. Burgerrn, unsers vermogens behulfflichenn zcu sein, wullen wyr uns, das zcuthon hirmit erbettenn habenn." (StadtA Mühlhausen 10/W 1-7 Bd. 16, Bl. 10 v/r, thanks to Peter Kuhlbrodt for communicating the digital reproduction).

81 Karl Joseph Stahl, Hadamar Stadt und Schloß. Eine Heimatgeschichte anläßlich der 650Jahrfeier der Stadtrechteverleihung an die Stadt Hadamar 1974, Hadamar 1974, p. 62f.

82 Bruno Crome, Kulturgeschichtliche Miniaturen vom Ausgang des Mittelalters aus einer alten Chronik, Göttingen 1921, p. 63.

83 Heege, Einbeck 1540, p. 34. 
in Jena, three fires broke out, two of which were arsons set in barns; on the basis of many suspected crimes, the city council has arrested and imprisoned four individuals who were just passing through, three of them in the district of Leuchtenberg and the fourth in the district court of Hans Puster. $^{84}$

Here too, torture was applied with permission from court authorities in Leipzig and the prisoners testified; the main offender was supposedly a certain Wenzel Voigt. The prisoners were executed on July 19 on the road from Jena to Leipzig. ${ }^{85}$ The electorate of Saxony had sent the interrogation files to Regensburg to his ambassadors; they were supposed to be forwarded to Landgrave Philipp. However, there the Protestant princes had already submitted a petition against the Mordbrenner arsonists to Duke Heinrich on May 13, which also appeared in print. The court testimonies (Urgichten) of the Mordbrenner ${ }^{86}$ were attached to it. Essentially, these documents reinforced the idea that the 1540 fires concerned anti-Protestant arson events, an idea that was intensified somewhat through polemics such as those by Luther in his leaflet written against Duke Heinrich, "Wider Hans Worst":87

Now-so that I may come to an end — this, I myself think, is the reason Harry [Heintze] the devil undertook to write such evil, slanderous, and deceitful books: he knows that throughout the world he has a most infamous name and that he stinks like devilish filth flung into Germany. Perhaps he would like not to stink so much himself, but would like to make other princes stink as well, so that it is not his stench alone which fills everyone's nostrils, particularly since this year the cry of arson was raised against him. He cannot drown these cries with soft words. Hence he must shriek and scream in his struggle to escape, cursing, slandering, lying, raving, and raging, just to see whether that would help. But it does not, Harry [Heintz], you rave in vain, even if you could thunder and storm like God himself. That mass of innocent blood shed at Einbeck and

84 Kurfürst Johann Friedrich to Fürst Wolfgang v. Anhalt and the others present at the Reichstag in Regensburg in 1541, Zwickau, 28 May 1541 (StA Weimar E Nr. 101, Bl. 232, WA Briefe IX, 345 n 7).

85 Adrian Beier, Mag. Adrian Beiers Jenaische Annalen (1523-1599), ed. Herbert Koch, Jena 1928, p. 22.

86 Supplication/an Keiserliche Maiestat/Der Mortbrenner halben/Auff dem Reychstag zu Regenspurg/Kayserlicher Mayestat vberantwortet, s.l. 1541 (VD16 E 4649, BS в Munich 4 Res 232, Beibd. 2), f. AiijV-EijR.

87 Martin Luther, "Wider Hans Worst [1541]," wA 51, 461-571, at 551. 
elsewhere where your arson cries so strongly to heaven that (if God wills) it will soon cry you and your associates down into the abyss of hell; and it will not cease till then. ${ }^{88}$

Heinrich protested in front of the emperor against the accusations of the Schmalkaldic petition in a 1541 reply. ${ }^{89} \mathrm{In}$ it, he points out that since his name was consistently suggested as the potential instigator during torture, the prisoners would be inclined to eventually testify to that, and also draws attention to other inconsistencies. He also brings up the point that according to the court testimonies in the petition, the target of arson is always only Protestant towns, and that therefore his own Catholic lands and the Mainz diocese should have therefore been spared; but in fact: "It is notorious and undeniable that there were likewise fires in my own country, in the episcopacies of Mainz, Magdeburg and Halberstadt."90 Also, the accused mercenary leaders Christof von Wrißberg and Christof von Oberg defended themselves against the accusations lodged in the published court testimonies. ${ }^{91}$ The chronicles and other sources concerning the Einbeck fire beautifully illustrate the religiously polarized framing of reality at play: on the one hand, a Hildesheim monk documented fiery clouds above Einbeck, which incinerated the city via punishing lightning strikes from God while explicitly sparing the gunpowder tower, so that this could not later be deduced as the primary cause, since the cause of the fires clearly lay with the guilty residents of Einbeck; on the other hand, the Lutheran Hanover Mayor Berckhusen also recounted the Heinrich Dieck arson story: in this rendering, it was now the St. Alexander church belonging to Duke Heinrich that remained untouched by fire, thereby making it clear that the arsonist had spared his own property. ${ }^{92}$

88 Martin Luther: “Against Hanswurst, 1541," trans. Eric W. Gritsch, in Luther's Works, ed. Helmut T. Lehmann, Church and Ministry III 41, ed. Eric W. Gritsch, Philadelphia 1966, pp. $179-256$, at 242 .

89 Hertzog Heinrichs von Braunschweig Antwort/Der Keiserlichen Maiestat/auff die vbergebene Supplication/der Mordbrenner halben/gegeben, s.l., 1541 (вSB Munich 4 DHg. 255, Beibd. 9).

90 Ibid., f. aivV.

91 Gedächtniß Christoffs von Wrißberg, des Kriegs Obristen, aus fast lauter alten ungedruckten Urkunden zusammen gezogen, Und zur Verbesserung verschiedener Geschicht-schreiber des $16 t e n$ Jahrhunderts, insonderheit des Schmalckaldischen Krieges, nunmehro zum Druck befördert, ed. Johann Justus Losius, Hildesheim 1742, supplement 1, 3-8-cf. Heege, Einbeck 1540, pp. 111-20.

92 Helge Steenweg, "Einbeck im Zeitalter der reformatorischen Bewegung," in Geschichte der Stadt Einbeck, ed. Horst Hülse on behalf of the Einbecker Geschichtsverein e.V., vol. 1, Von den Anfängen bis zum Ende des 18. Jahrhunderts, Einbeck 1991, pp. 135-54, 135f. In a 
It is therefore difficult to determine retrospectively whether one of the most notorious Mordbrenner series of the early modern period truly should have been characterized as such, or whether the religiously framed presuppositions and the always incipient logic of the search for a scapegoat made this series of fires into Mordbrenner fires. Similar spirals of blame are associated with almost all major fires. Questions of whether antipapal polemics in the context of the hated Frenchifying royal court influenced the trail and execution of the Frenchman Robert Hubert following the 1666 fire of London, or whether the Istanbul fire of 166o was interpreted as a sign of necessary purification and used as an opportunity for the expulsion of Jews and Greeks and for the Islamization of additional sections of the city, ${ }^{93}$ often employ a similar logic and despite or, in fact, because of the large number of sources produced in the course of such discourses of blame, the historian usually cannot definitively answer questions regarding the "actual" cause. Retrospectively, however, in the context of a climate anomaly that is well established in climate history, the observer does have access ex post to a further pattern of explanation. In the context of other city fires in 1540, which did not take place at the northwestern confrontational border between Catholic and Lutheran towns and territories, allegations of Mordbrenner were unheard of. In Großenhain, the first victim was the Orthodox Maria-Magdalene convent; in Erkelenz, a Catholic "bulwark"

statement by the council of Einbeck itself to the Göttingen council there is still primarily ignorance concerning process and cause; only unsurprising common sources of fire, such as wind and flying sparks, were reported.

93 Marc David Baer, "The Great Fire of 166o and the Islamization of Christian and Jewish Space in Istanbul," International Journal of Middle East Studies 36, 2 (2004), pp. 159-81; Stephen Porter, The Great Fire of London, Phoenix Mill 1996; Adrian Tinniswood, By Permission of Heaven. The story of the Great Fire of London, London 2004, pp. 163-89. Concerning the complicated London case one should recall that while Hubert declared himself to be Catholic and pleaded guilty, most witnesses identified him as a Huguenot. However, his testimony was, in the end, decisive for the case and was the primary factor that led to his execution and to the creation of the myth of "papist" arson, later memorialized on the plaque erected in Pudding Lane in 1681: "Here by Permission of Heaven Hell broke loose upon this protestant city from the malicious hearts of barbarous Papists by the hand of their agent Hubert [...]" (ibid., Fig. 30 und LMA London, Journals of the Court of Common Council 49, f. 224r). Similarly the inscription on the Fire Memorial, in honor of the "Furor papisticus," which was supposedly responsible for the "dreadful Burning of this Protestant City" with the goal of "carrying on their Horried Plott, for extirpating the Protestant Religion, and old English Liberty and Introducing Popery and Slavery" (ibid.). Regarding the monument, see Matthew F. Walker, "The Limits of collaboration: Robert Hooke, Christopher Wren and the Designing of the Monument to the Great Fire of London," Notes \& Records of the Royal Society 65 (2011), pp. 121-43; Field, London, Londoners, $45^{-48}$. 
belonging to the bishopric of Lüttich (Liège) was also completely destroyed in the midst of Lutheran-Calvinist reformation movements; Bingen was also an important town in the region controlled by the Archbishop of Mainz. ${ }^{94}$

All in all, against the background of the fire statistics for Germany as a whole in the climatically exceptional year of 1540 , it appears very likely that the whole group of Mordbrenner stories, particularly concerning the Einbeck fire, belongs more to the area of scapegoating. Even if these fires were not all directly caused by the heat and dryness, statistically the mere number of fires is clearly attributable to the "megadrought", a climactic condition that would at least significantly intensify fire. This all suggests that 1540 was a year not of Mordbrenner fires, but rather one of climatically induced fires-a suggestion which also corresponds with the historical record of fires in other regions of Europe. ${ }^{95}$

In second-place after 1540 in the approximate millennium of the Städtebücher data is 1666, in which a disproportionally high number of fires not easily attributable to a war event also occurred (29 are known). The 165 os and 166os also endured a surprisingly high number of major fires worldwide: the largest fire that ever struck the exceptionally fire-prone city of Constantinople/Istanbul, occurred in 166o. The largest fire ever to hit Edo/Tokyo dates to $1657 .^{96}$ The London fire of 1666 figures into general cultural memory as the "mother of all fires." The prominent fires noted in more recent German history

94 Wilfried Setzler, Benigna Schönhagen, Hans-Otto Binder, Kleine Tübinger Stadtgeschichte, Tübingen 2006, p. 70; Jürgen Sydow, Geschichte der Stadt Tübingen, vol. 1, Von den Anfängen bis zum Übergang an Württemberg 1342, Tübingen 1974, p. 74; Von der Ackerbürgerstadt zum Oberzentrum. 9o Jahre Haus- und Grundbesitzerverein Weiden und Umgebung, Weiden 1998, pp. 76-78; Heinrich Stöcker, Krieg, Pest und Brand im Großenhainer Land, Großenhain 1998, pp. 26-30; Hans-Josef Broich, "Erkelenz. Geschichtliches Portrait einer Stadt," Der Niederrhein 75 (2008), pp. 114-17, 116; Friedrich Hermann Hoffmann, Die Kunstdenkmäler von Oberpfalz und Regensburg, Bezirksamt Parsberg 4, Munich 19o6, p. 218; Hellmut Rogowski, Verfassung und Verwaltung der Herrschaft und Stadt Jever von den Anfängen bis zum Jahre 1807, Göttingen 1967, p. 26; Walther Zimmermann, Hugo Berger, Friedrich von Klocke, Johannes Bauermann (eds.), Handbuch der historischen Stätten Deutschlands, vol. 3 Nordrhein-Westfalen, Stuttgart 1963, p. 182 (Erkelenz), 206 (Freudenberg); Jacob Keuscher, Die Feuerbrände der Stadt Bingen in den Jahren 1403, 1490, 1540, 1689 und 1850. Ein Beitrag zur Geschichte dieser Stadt, Dannstadt 1853.

95 Cf. Paul Delsalle, "'Lorvale de feu' dans les villes et les campagnes comtoises (1493-1634)," in Vion-Delphin and Lassus (eds.), Les hommes et le feu, pp. 253-73, 269.

96 Noel Nouet, The Shogun's City. A History of Tokyo, Sandgate 199o, pp. 47, 105f.; Kaoru Ugawa, The Great Fire of Edo (Tokyo) in 1657, in Körner, Stadtzerstörung, vol. 1, pp. 213-238; Jordan Sand and Steven Wills, "Governance, Arson, and Firefighting in Edo, 160o-1868," in Greg Bankoff, Uwe Lübken, and Jordan Sand (eds.), Flammable Cities. Urban Conflagration and the Making of the Modern World, Madison 2012, pp. 44-62. 
of Passau in 1662 and Annaberg in 1664 also fall within this time frame. ${ }^{97}$ The two decades between 1650 and 1669 boast approximately 250 fires in central Europe, excluding those caused by the First Nordic War. Thus, taking warinduced fires out of the equation, these two decades-located in a position in climate history immediately preceding the "Maunder Minimum," which coincided with the coolest point of the "Little Ice Age"-comprise the two most fire-dense decades in the period. From the 1720 on onwards, however, such values were no longer reached, and the decades of the Thirty Years' War, as well as the period 1670-1719, were so heavily influenced by the war that a valid comparison seems quite impossible (the values are actually only marginally higher and an exact comparison is not possible with the current state of precision in the database, furthermore, since not every fire involves the question of war-induction, one often reaches the limits of research). The year 1666 also shows up as an anomalous year for historical climatologists-from the end of April until September, unusual drought and heat dominated the climate in central Europe and also in Switzerland. ${ }^{98}$ All non-war-related fires of the year 1666 occurred exclusively in northern Germany-from Westphalia, to Brandenburg, Saxony-Anhalt, and East Prussia: Beelitz, Dahme, ${ }^{99}$ Frankfurt an der Oder, Kyritz, ${ }^{100}$ Lenzen, Luckau, ${ }^{101}$ Neustadt/Dosse, Rathenow, and Teupitz in Brandenburg; Deutsch Neukirch (Altstett), Deutsch Wartenberg, Löwen, Bischofstal (Ujrest) in Silesia; Ellrich, Gommern, Könnern, Querfurt, Schafstädt, Stendal and Werben in Saxony-Anhalt; Falkenburg in East Pomerania; Mehlsack in East Prussia; Neukalen in Mecklenburg;102 Altena, Freudenberg and Sendenhorst in Westphalia. In the locations with existing fire data, the

97 Allemeyer, Fewersnoth und Flammenschwert.

98 Glaser, Klimageschichte Mitteleuropas, p. 16o; Pfister, Wetternachhersage, p. 189; also cf. the nine (of forty-eight) source documents relating to 1666 in content or temporality from ClimDat: http://mitgliHg.lycos.de/milio4/1640_1699.html; Kathleen Pribyl, "A survey of the impact of summer droughts in southern and eastern England, 1200-1700", Climate of the Past 16 (2020), pp. 1027-1041, here 1036.

99 Werner Reinhold, Chronik der Stadt Dahme und der Umgegend, Dahme 1845, p. 48. Many town residents were in a church, where a wedding was taking place: "Since there was a great drought at that time and the houses were primarily covered with straw or thatch, the fire grew so quickly that within one hour the city was not only fully engulfed by flames, but, to a large extent, already reduced to ashes."

100 Not mentioned by Hans Gressel, Die Stadt Kyritz. Entwicklung, Verfassung und Wirtschaft bis zur Städteordnung 1808/og, Berlin 1939.

101 Rudolf Lehmann, Geschichte der Niederlausitz, Berlin 1963, p. 280.

102 Friedrich Schliemann, "Zur Geschichte der Stadt Neukalen," Archiv für Landeskunde in den Großherzogthümern Mecklenburg und Revüe der Landwirthschaft 12 (1862), pp. 511-57, 641-58, here 641 . 
fires consistently occur in the window from late June to late September, when climate-historical drought and heat were exceptionally intense. Thus, the data would suggest that 1666 can also be characterized as a climatically induced fire year. This also means that the London fire, in some respects, can be categorized as "one of many" in northern Europe.

\subsection{The Fire Ecology of Hamburg}

As has been shown, the establishment of fire-trend statistics across an entire land or region is plagued with a variety of uncertainties. For one thing, the data density is too low, for another, factors like war induction vs. climate induction are difficult to precisely isolate within the current state of research. ${ }^{103}$ In the end, the view of major fire trends offers a kind of a collective fire biography for Germany, which provides significant insights into the intensity of major fires and how they were controlled. Regarding the question of the quotidian threat and also the question of the danger that people began to insure themselves against, small fires ranging from a single house fire up to several blocks of destroyed houses were more important than the threat of an overwhelming, devastating fire resulting in widespread destruction, against which protective measures were always in place anyway. These major fires contoured the horizon of anxiety and concern, and the need for security stimulated and offered starting points for processes such as "learning from disasters", although we also frequently encounter moments and periods of disaster amnesia in history, where lessons eventually learned became forgotten. If those long term developments represent something like a "danger profile" (as they would not yet speak of a "risk profile" in those premodern times) from the point of view of the human perception of a supranational, national or regional population, for individual cities, however, such a "danger profile" can more easily be shown at the level of a series of house fires. Unfortunately, such a detailed fire historyand therefore the sketch of such a "danger profile" - is not possible for many cities due to the lack of the necessary sources and fire data. Only after fire insurance had been established (during and after the eighteenth century), did such data start to be gathered for many cities. Some cities, however, do provide exceptional data for earlier periods, such as Hamburg, for Germany, which offers access to three different types of data.

103 Even today there is a lot of uncertainty regarding that question: now as before, reinsurers engaging in causal analysis, who attempt to account for the sheer constant growth of damage values caused by natural distasters, cannot give any definitive answer regarding the proportion of causality attributable to "climate change" vs. the simply increasing volume of exposed values. 
- the number of destroyed houses per fire since the sixteenth century, regardless of whether they were insured or not.

- the number of firefighting incidents (Feuerausläufe) - -i.e., the actual instances when firefighting equipment and personnel were mobilized-since 1773 .

- the number of claims payments on the part of the General Fire Fund (General-Feuer-Casse) since 1683.

The fire and firefighting incident numbers are precisely known thanks to the assistant fire chief, Johann Ehlert Bieber, who recorded them from 1773 until the great fire of 1842. There is no other city in Germany, and only few in Europe, that can lay claim to a similar longly and precise data series - in spite of the discrepancies and uncertainties that will be discussed. Through this material, a true fire physiognomy of the city can be constructed.

Bieber belonged to a Hamburg-based dynasty of fire and insurance specialists. His father, Georg Ehlert Bieber (1761-1845) was head fire chief for decades, alderman (Oberalter) for the St. Nicholas parish district, and founded the private Fire Insurance Association in 1795, which went bankrupt after the fire of 1842. Johann Ehlert Bieber specifies that he can vouch for the absolute correctness of the data only for the years from 1772 on, "because the sources [concerning the previous time period] [were] not very reliably recorded." A spot check based on the ledgers of the General Fire Fund shows that, at least for the second half of the seventeenth and for the eighteenth century, the data are indeed almost entirely accurate. Only the smallest fires, causing damages of less than about 1,000-2,00o marks courant, are not listed. ${ }^{104}$ Bieber started a tradition of recording verifiable fire statistics at the end of the seventeenth century that was also continued by Fire Chief Ammon. ${ }^{105}$ Bieber's list records the number of houses burned per fire and also, from the year 1772 on, the number of "Ausläufe" per year-i.e., all incidents involving the mobilization of firefighting resources-even those concerning minor fires.

In analyzing Bieber's data, ${ }^{106}$ the frequency of fires during the eighteenth century is remarkably low (Fig. 19). The relative fire scarcity characterizing the century of the Enlightenment (which, as discussed above, was also the case for the entirety of Germany as well as for England, in terms of major fires) is framed

104 Cf. HStA Best. 331-1/1, I-1, Bd. 2, f. 79-81, 83, 85, 87, 88, 94, 95, the entry on fires for the year 1767 have been checked.

105 Cf. HStA Best. 331-1/1, II-4, Bd. 1, f. 1-77: the fire damages from 1684 to $1710 / 12$ are documented here with few gaps. In HStA Best. 111-1, Cl. VII. Fe Nr. 3 Vol. 5: Ammon's fire list for $1717-5$ o.

106 Ibid. 


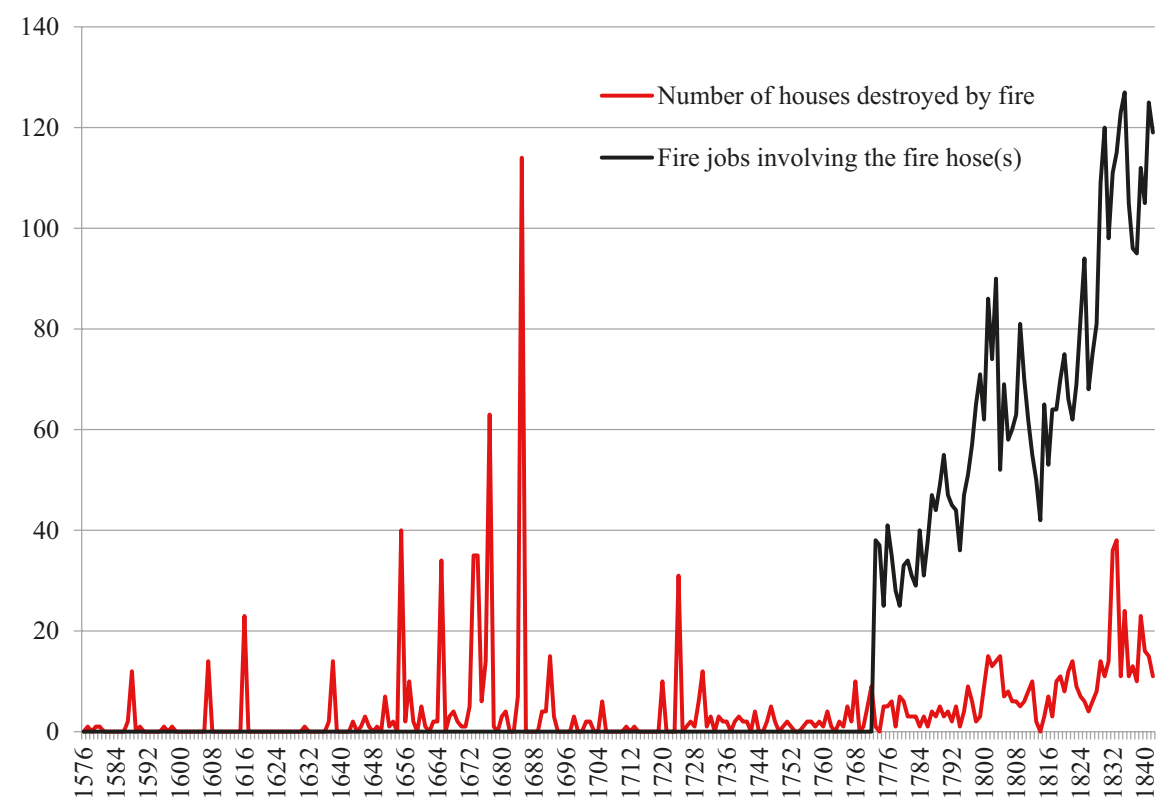

FIGURE 19 Number of destroyed houses per fire (red) and firefighting incidents recorded (black) according to descriptions by Johann Ehlert Bieber, Verzeichniss aller Feuersbrünste in Hamburg und der Umgegend, von 1281 bis 1830, Hamburg 1830 (StAHamburg Bibl. A 456/18: continued hand-written until 1841)

by the fire-dense periods of the late seventeenth and early nineteenth centuries. Even based on this observation alone, it is clear that the discursive overmodulation of the enormity of the Michel fire of 1750 (as will be discussed in the section of this study concerning perception and reality [Ch. 3, 2.1]), as well as the impetus for the reform of fire policey management during the eighteenth century and the Enlightenment dynamics of lightning-rod proponents (see Ch. 3, 3.1.2), are factors that cannot be reduced to the simple logic of "major disasters and great risks lead to reform reactions." Rather, there seems to be an intrinsic logic at work here, which perhaps, in view of the longue durée, actually originated in the crisis-like context of the late seventeenth century. In the case of Hamburg, the element of war-induced fires is of no importance for the relevant time period.

However, it is important to avoid falling prey to the false impression that can be easily generated by the graphical visualization: the high peaks during the late seventeenth century - in particular the peak associated with the great fire of 1684-must not obscure the fact that the sum total of destroyed houses between 1650 and 1700 (435) is less than the total in the period 1800 to 1841 (470); in the nineteenth century, the average fire risk increases steadily and annually 
until 1842 without the occurrence of a major disaster. It is also important to correlate these values with population numbers. In $165^{\circ}$ there were approximately 6o,ooo inhabitants in Hamburg, and around 1750, nearly 75,000. The frequent large fires thus can hardly be viewed in a causal relationship to the population increase, which was relatively limited. In contrast, the relatively rapid population increase from 75 ,000 in 1750 to 100,000 in 1787 and 130,000 in 1800 did not substantially affect the number of houses destroyed by fire. The mean value for the period between 1780 and 1805 was 5.61 houses destroyed by fire per year (with four fire-prone years between 1800-03); during the time of French occupation between 1806-14, when the population dropped dramatically to 55,000 inhabitants, the average number of houses burned remained relatively steady at 5.75 ; in $1815^{-27}$ the number rose to 8.08 ; and in $1827-41$ it rose fairly dramatically to 17.6 . The population in $1815^{-26}$, directly following the French period, had just reached 122,00o and in 1834-40 it rose slightly to 130,000-136,000-i.e., approximating the population of 1800 before the occupation. The sudden increase in the average number of houses burned after the French period, but particularly after 1827 , is thus in no way proportional to population growth. At the time of the major fire of 1842 , Hamburg was not a quickly growing city like, for example, Chicago of 1871 , where the population almost tripled from about of 109,000 to about 300,000 in the ten years before the fire. ${ }^{107}$ On the contrary, after the recovery from the population collapse during the French occupation of 1806-14, population growth in Hamburg was rather stagnant, and it was only after the fire of 1842 that a particularly dynamic growth phase began again. The rapid rise of numbers reflecting fires and firefighting incidences obviously reflects an actual increase in the fire danger for Hamburg (and its early perception and accounting as risk from the middle of the eighteenth century).

For purposes of comparison, the particularities of the fire fund records (Generalfeuerkasse) should also be addressed. These numbers were recorded in different formats, and the deviations between different currencies (e.g., bancomarks, Lübisch marks, marks courant) are not always easy to identify in the archival material itself, nor are they always disclosed in the literature. Therefore the number values that Borscheid/Drees give in the historical insurance statistics of Germany for the Hamburg-based fund are in many cases uncertain. In addition to the sources given by Borscheid/Drees and the 1976 overview created by Oakley and Spohnholtz, there are also figures in other archives 
that differ substantially from the Borscheid/Drees information. ${ }^{108}$ Because of this unclear data situation, the following are based on a new reconstruction from these archival sources (Fig. 20). ${ }^{109}$

Concerning the earliest records from 1684 to 1713 , the figure below illustrates discrepancies between the Borscheid/Drees data and the numbers recorded in 1794/95 by the long-tenured head fire chief and founder of the first private fire insurance company in Hamburg, Georg Ehlert Bieber:

While according to Georg Ehlert Bieber's figures there were several years recording no damages - which is quite likely — and other years (see especially $1767,1786,1794 / 95)$ recording relatively high numbers, the Borscheid/Drees numbers are consistently below the 50,000-mark line, but suggest a continuity of damages and payments. These numbers illustrate the difference between damage events and the completion of payment, which was often delayed or extended over many years. The Borscheid/Drees statistics thus merely serve

108 StA Hamburg Best. 333-1/1, Nr. IV a2, vol. 1, f. 58-78 contains, for example an exact listing of all that damages that incurred in the years 1684-1713; admittedly the values in Borscheid/ Drees (Versicherungsstatistik, p. 195f.) reflect annual damage payments and not the damage values actually incurred, but even the total amount for 1684-1713 differs by almost 400,000 (Bankomark?) (= ca. 30\%). Concerning the "Bilance der General-Feuer-Cassa auf ultimo December 1809" in HStA Hamburg Cl. viI, Lit. Fe Nr. 3 Vol. 13, nr. 1 the 1808 Borscheid/Drees numbers in the column "Zahl der Policen in T Bco. M" (5218) and the column "Versicherungssumme in Bco. M"(78.856.477) are in complete correspondence; however, neither the amounts (Borscheid/Drees: 35.247, Balance: 39.684 plus 2.116 for invoicing taxes and increase of insurance amounts), nor the rubric "Schadenszahlungen (damage payments)" (Borscheid/Drees: 26.703, Balance: 13.048) correspond with each other. Furthermore, all values on the balance sheet are clearly given in marks courant, while Borscheid/Drees uses bancomarks. The other balance sheets given in the same volumes for the years 1817-1822 also differ significantly from the Borscheid/Dress numbers in terms of contribution and damage amounts. For all balance sheets between 1823-1859 (with the exception of the years 1849/50) that are presented in their entireties in HStA Hamburg Cl. viI Lit. Fe Nr. 3 vol. 16, it is possible to precisely determine which values have been included in the Borscheid/Drees statistics: while the column "damage payments" represents actual fire damage amounts paid in a given year (excluding other expenditures such as taxation costs of the estates), regardless of whether they were incurred in the same year or earlier, this situation is reversed for the column "Beiträge (contributions)," where the target of the fire fund allowance due that year and the supplementary payments for fire-extinguishing efforts were deducted, irrespective of if and how much of these amounts had been accrued in the current year. Here, the two values were combined, and appear in the balance sheets within an undifferentiated rubric. Additionally, the numbers are presented here not in marks courant (the currency in which the fire fund balance sheets are always given), but in bancomarks instead (in 1859 the exchange rate was approximately 100 bancomarks to 125 marks courant).

109 Source: value of damages: StA Hamburg Best. 333-1/1, Nr. IV a2, vol. 1, f. 58-78; damage payments: Borscheid/Drees. 


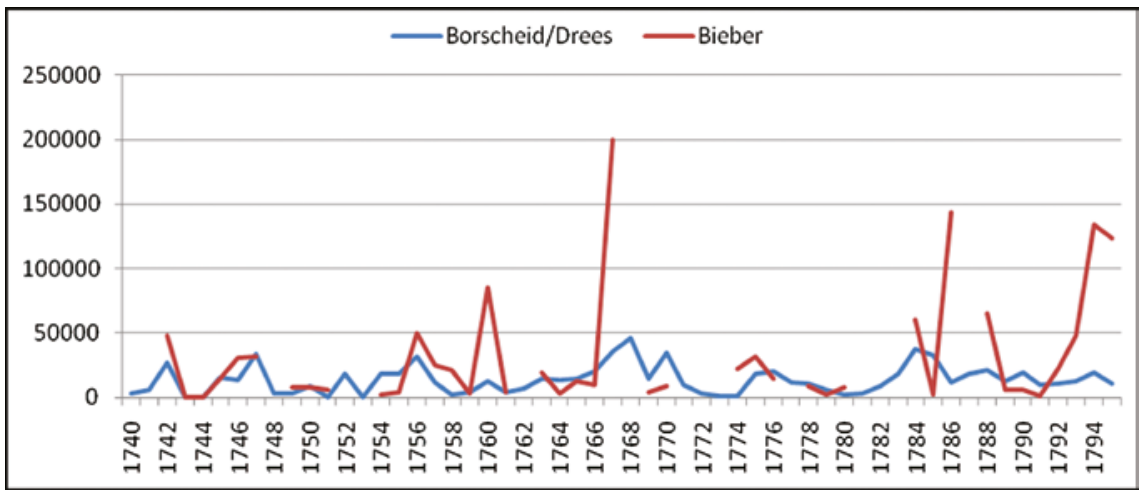

FIGURE 20 Comparison of the Borscheid/Drees damage payment amounts (blue line) and Bieber's damage amounts (red line) 1740-94

SOURCE: damage payment amounts: Borscheid/ Drees, Versicherungsstatistik; damage amounts: Georg Ehlert Bieber, Prüfung der Bemerkungen eines

Ungenannten über die Vorläufigen Puncte einer Association Hamburgischer Einwohner, zur gemeinsamen Versicherung ihrer Mobilen-Güter, S.l., i.e. Hamburg 1795, pp. 1-4-the numbers given there differ in individual cases from the previous version in Georg Ehlert Bieber, Plan zur Errichtung einer für Hamburg möglichst vortheilhaften Versicherungs-Compagnie gegen Feuers-Gefahr entworfen und seinen Mitbürgern gewidmet, S.l., Hamburg 1794, p. 3 f

to demonstrate the completion of the payment processes and the cash flow in the fire fund, but cannot serve as a measure of the actual damage level associated with fires over the course of a year. Looking at the Bieber data, however, one can easily see how four extremely expensive years $(1767,1786,1794 / 95)$ are hardly even noticeable in the statistics above regarding the numbers of destroyed houses and firefighting incidences: among the fires of 1767 there were two sugar factories owned by Nicolaus Ernst Gädgens and Filster ${ }^{110}$ as well as the house (and warehouse?) of the Huguenot merchant Chaunel that burned; in 1786 the estate of Baetke and Rodatz was hit by fire; and in 1794/95, the sugar factory of Thode and Biesterfeld and the Köster estate burned. Sugar factories and stores were typically very fire-prone early industrial businesses and also represented high value exposure for the rich merchants of the trade city-but, in the end, they are simply recorded as " 1 house" or " 1 firefighting incident" in other forms of accounting. But all in all, the numbers are roughly congruent

110 Description of fire causes in HStA Hamburg Cl. viI, Lit. Fe Nr. 2, vol. 19, nr. 5, p. 46. 
with the number of destroyed houses according to Johann Ehlert Bieber (see above): the distribution of the early modern fire characteristics of Hamburg in the fire-prone late seventeenth century, a fire-scarce eighteenth century, and a fire-heavy early nineteenth century is demonstrated by these numbers.

On the basis of various data series, it is clear that contemporaneous administrative specialists already realized these characteristics that have become evident ex-post to historians. In particular, they noticed the increase in the risk of fire beginning at the end of the eighteenth century. In 1787 Senator Ankelmann assembled the following overview of fire damages:

$\begin{array}{ll}1691-1709 & 195314 \mathrm{MC} \text { [marks courant] } \\ 1701-1710 & 248351 \mathrm{MC} \\ 1711-1720 & 68889 \mathrm{MC} \\ 1721-1730 & 114268 \mathrm{MC} \\ 1731-1740 & 98155 \mathrm{MC} \\ 1741-175 \mathrm{O} & 91454 \mathrm{MC}\end{array}$

Thus over 6o years, $816431 \mathrm{MC}$, or annually $13607 \mathrm{MC}$.

However, from 1766-1786, 31963 MC, or annually 15981 MC. ${ }^{111}$

Although these values differ slightly from the above sources, it is interesting, that such observational data suggests that the administration recognized these trends well before George Ehlert Bieber's 1794 calculation of average damage values - which, however, were for the primary purpose of founding his own private insurance company. It is tempting to compare this admittedly very simple form of calculation with the probabilistics already common in the field of life insurance. Ankelmann's calculations-which served as an argument for increasing contributions-incorrectly suggest that the increase in the values took place in the period 1766-86, in particular due to the two exceptional peaks of 1767 and 1786 . The pressing perception of the increase in fire danger that also resulted in fire policey efforts and discussions within the Patriotic Society was, in any case, obvious in Hamburg in the decades after about 180o: "there is no mistaking, that in the preceding months, the fires everywhere have been dramatically increasing again, and that they have been almost always started by flammable factories" is reported, for example, in $1826 ;{ }^{112}$ in 1829 it is recalled that "in recent times there are often large fires that ignite in the fire-prone

\footnotetext{
111 HStA Hamburg Cl. viI, Lit. Fe Nr. 3, vol. 9, nr. 9.

112 HStA Hamburg Cl. viI, Lit. Fe Nr. 2 vol. 36, nr. 1 a (January 28, 1826).
} 
factories"; 113 in 1827-31 there are constant investigations of this problem; and also in 1835 it is questioned "whether there are general measures that could be taken, in order to prevent the frequent fires?"114 The ruling elite of the city constantly considered remedies, but apparently without success. In actuality, the effects of early industrialization are clearly demonstrated here, as becomes apparent when the various fire inventories can be qualitatively evaluated. Among the approximately 575 destroyed buildings that Johann Ehlert Bieber recorded for 1772-41, there were 48 sugar factories, 17 distilleries/breweries, 7 bakeries, 5 windmills, 4 calico factories, 2 paper mills, 2 candle factories, and also a dyeworks, a printing press, a wallpaper factory, a tobacco factory, a charcoal factory, a "bone-blacking" [i.e., coal] factory, a cotton mill, a leather factory, a machine factory, and part of a steam mill. Also among the 66 buildings damaged by fire that the Ehlert Association paid for in its early years of existence between $1795^{-1802}$, there were 14 sugar factories, 4 calico mills, 1 leather store, 2 carpentries, 1 carriage factory, 1 wallpaper factory, 1 pottery store, 1 distillery, 8 department stores, 2 flour dealers, 1 mill, 1 wood trader, 4 pubs, 1 wine cellar, and 2 goods rooms: ${ }^{15}$ this list comprises places of trade and early industrial practices that were extremely risky to insure in terms of both fire risk and damage amounts. The number of burned sugar factories decreased somewhat in the late 1820s, which coincides with the decline of this industry at this point (or reflects its earlier boom due to the Continental Blockade).116

A structural reason for the demonstrated increase in the Hamburg fire risk from about 1800 on is a significantly disproportionate amount of specifically fire-prone trades - characterized, above all, by the Hamburg sugar-refining industry, ${ }^{117}$ a still very unregulated transitional industry, often located in normal residential buildings, in a quickly evolving landscape of factories and manufacturing industries. Although on the infamous night of May 4-5, 1842, a fire broke out not in such a sugar factory, but in the home of a tobacco merchant,

\footnotetext{
113 Ibid., Nr. 3.

114 Ibid., Fe Nr. 2 vol. 40.

115 HStA Hamburg Cl. vil Lit. Fe Nr. 2 vol. 28a, nr. 27.

116 Astrid Petersson, Zuckersiedergewerbe und Zuckerhandel in Hamburg im Zeitraum von 1814 bis 1834 . Entwicklung und Struktur zweier wichtiger Hamburger Wirtschaftszweige des vorindustriellen Zeitalters, Stuttgart 1998, pp. 58, 229. 1807 was the highpoint with ca. 428 businesses, in 1834 the number had declined to 194 businesses; see ibid., pp. 225-33.

117 A 1797 recommendation of the Hamburg Patriotic Society pointed out the "relatively large waste of fire ... in the fire-hungry kettles of the sugar refineries" (Verhandlungen und Schriften der Hamburgischen Gesellschaft zur Beförderung der Künste und nützlichen Gewerbe, 7 vols., Hamburg 1792-1807, vol. 6, p. 389, qtd. in Petersson, Zuckersiedergewerbe, p. 54).
} 
the spread of the fire was aided in particular by a "reservoir filled with spirits and rum ... (of Ross \& Vidal)"; with its character as a remote trading center, the fire easily spread across the city through the especially flammable storage buildings. ${ }^{118}$ In the initial decades of the nineteenth century, Hamburg found itself in a transitional phase, in which pre- and early industrial trades shaped the image of the city; as they reached a critical mass, it created a high fire risk on a structural level for the city.

Thus, on a purely statistical level and according to an increasingly dominant perception, the great fire of 1842 was a disaster with a message, so to speak-a disaster which corresponded with the image of increased risk characterizing this time period and context in particular. Although in many senses it continues to recall the terrifying premodern pattern of the quotidian threat of major fires, it must simultaneously be categorized much differently — as a symbol of the risk pattern of early industrialization.

These Hamburg data are definitely not broadly representative, because Hamburg, as the largest port and maritime trade city, was a typological exception. The high number of early industrialization-era sugar factories was hardly found in other German cities in the hinterlands. In fact, there are few cities at all with which appropriate comparisons could be made at this point in time. While the old imperial cities, for the most part, lived through early modernity without major fires - probably due to a strong position acquired by investing in stone buildings at the beginning of the late Middle Ages-they also seem to have failed to develop the requisite meticulousness of quantifying introspection. The accounting practice of coding reality in numbers spread earlier in the institutions of the cameralistic administrative state and in centers of technical-economic Enlightenment like Hamburg. For Cologne, for example, it is true that in order to satisfy the firefighters' demand for a gratuity for each extinguished fire, an annual count of the actual fires was performed (cf. Ch. 3 , 3.1.1). However, nothing of this practice ${ }^{119}$ is preserved in any systematic form and it also does not appear that such statistics were collected over many years. Aachen, the only major imperial city that was completely destroyed by fire in the early modern period-in 1656 , by the largest German city fire before Hamburg's - completed reconstruction in the traditional way, without any

118 F.R. Schrader, "Aus den Tagen des großen Brandes," ed. Theodor Schrader, Mittheilungen des Vereins für Hamburgische Geschichte 15 (1892), pp. 378-83, 379; Ortwin Pelc, "Hamburg 1842. Eine Katastrophe verändert die Stadt," in Claudia Horbas and Ortwin Pelc (eds.), Es brannte an allen Ecken zugleich. Hamburg 1842. Ausstellungskatalog des Museums für Hamburgische Geschichte, Heyde 2002, pp. 9-15, 9.

119 Or "survived," after the collapse of the city archive. 
major changes in the city structure and with few indications pointing toward greater reforms in fire policey. ${ }^{120} \mathrm{~A}$ fire-statistical assessment was not undertaken by the city - or at least there is no evidence of one. The fact that Aachen then, in the early nineteenth century, served the location of one of the earliest and largest German private fire insurance companies was due not to a previously existing administrative culture-as, for example, was the case in Hamburg with the practical knowledge of the principle of insurance and a tradition of recording and observing its own security regime in the "code of numbers" - rather, it emerged from a completely new sector, gaining access at the economic level of modern industrial capitalism.

\subsection{Summary}

The sheer representation of fire statistics, the demonstration of the influences of war and climate, and a single more-detailed urban fire ecology or "fire biography" of a city like Hamburg should be accompanied with an illustration of the threat encountered in everyday life, as distinguished from the danger in the premodern era. In some respects, one might confidently make the judgment that there is nothing surprising about the distribution of fire, about the war- and climate-induced fires - that they rather confirm, with a bit of accuracy, what one would expect. The relatively early decline in the high risk of fire during the eighteenth century (the early spread of the "fire gap") is more surprising and may help to explain why, especially in that century, city fires begin to increasingly appear as the unspoken exception to normality, although true fire security in towns and cities was still far from comprehensively achieved.

Further detailed research for other single cities like Hamburg, which could punctuate, change, or complement this broad view of everyday fire danger

120 The relevant group of sources regarding the reconstruction (Stadtarchiv Aachen, RA II Allg. Akten 577: correspondence between near and distant cities, dukes, princes, and potentates, but also an interrogation protocol of May 17, 1656 concerning the causes of the fire), the city council protocols that begin after the fire (Nr. 1: 1656-1660), as well as the ordinances and the series concerning the city's officers (Stadtarchiv Aachen, RA II Edikte II 1 und RA II Beamtenprotokolle vol. 1 (1656-166o) bear evidence of quite traditional resilience measures taken by the city administration — no truly innovative impetus can be detected; cf. Claudia Kunitz, Aachen nach dem Stadtbrand. Wege und Maßnahmen zum Wiederaufbau 1656-1661, MA thesis, RWTH Aachen University 1994; Thomas R. Kraus, "Der Aachener Stadtbrand vom 2. Mai 1656 und seine Folgen," Zeitschrift des Aachener Geschichtsvereins 109 (2007), pp. 35-99. There are no fire policey files for the period after the fire that would offer insight into whether a statistical inquiry produced by the city administration: probably such analytical proto-state bureaucracy did not exist. 
would be useful, because a large number of prima facie unexplainable peak fire years could still be compared to regional findings within climate history, or other local explanations could potentially be found. While the seventeenth century can be characterized as a century of wars and epidemics, it is also clearly an exceptional period in terms of fire crises. Research has yet to offer more detailed and comparable fire histories beyond the existing pioneering but rudimentary lists — provided, up to this point, by historiography. A short comparison with the English Porter/Jones list demonstrates that very different numbers can be expected in different countries and that thus the fire history of Europe may be far more multifaceted than is currently imagined. For the following chapters, the analysis given here can serve the purpose of representing the "reality of the danger." From that starting point, the question must be pursued of how this reality of a threat was perceived and what developments were catalyzed by it in the means and mechanisms of security production.

\section{$2 \quad$ The Perception of Danger}

The Theology of Divine Punishment and the Fire Events of the Seventeenth and Eighteenth Centuries: Security Losses, Security Gains

In the late Middle Ages and early modern period, fire was almost always interpreted as a disaster sent by God to punish the community for sins and immoral behavior, the particularities of which were typically specified after the fact. This interpretation is found, first and foremost, in the sermons presented by local clergy after fire events. Popular sermons featured acts of divine destruction in Biblical cities such as Nineveh, Sodom, and Gomorrah, and it was emphasized that the punishment of Christian cities was also within the purview of divine providence. The basic elements and rhetorical patterns of fire sermons were always similar and the sins subject to divine punishment by fire were typically defined by preachers as immoral behavior-in particular, sporadic church attendance. The fires thus also served as moments that ministers could exploit to gather the lambs of the congregation together through incentives of fear, concern, and the search for consolation. In addition to chastising tirades, the sermons usually also included consoling remarks and calls for devout, Christian behavior in the future. As such, fires were often used by preachers for purposes of periodic reformation and as an opportunity for the re-Christianization of their congregations. For example, as David Underdown argues, the burning of the city of Dorchester in 1613 resulted in a multiyear 
religious reform of the city collective that transformed Dorchester into the most "Puritan" city in England. ${ }^{121}$

The highpoint of fire sermons occurred between the second half of the sixteenth century through and during the entire seventeenth century. Preachers reliably interpreted events as punishment for a long, unrepentant period of carelessness:

All that said, Oh city of Giengen, Oh dear fatherland, you haveunfortunately - a very transient, forgettable memory [labilem memori$a m$ ] [of prior fire conflagrations in other cities].... Because we find here a Magna securitas, a great carelessness [Sicherheit], as one lives here safe and secure throughout the day. Some think that because today there is peace and no hardship, they might always live in safety and security. But it is said: Well, God will not and cannot leave this great safety and security unpunished; he will soon unite us anew in his wrath. ${ }^{122}$

The Giengen evangelist Simon Böckh (about whom there are no in-depth studies beyond local histories) can be recognized as representative of a certain type of orthodox Lutheran preacher: his anti-astrological treatise, published in 1681, positions him as a true anti-Philippist perhaps even opposed to ideas of natural theology. ${ }^{123}$ However, there are two noteworthy points in the above passage. First, we can identify a reflection on the relationship between memory (memoria) and disaster, which was apparent in the tradition of the medieval and rinascimental ars memoriae. Here it is expressed as a duty of believers to remember past punishments for the present and for the future; more recent disaster history, in contrast, questions the relationship between collective memory and post-disaster resilience in terms of a sociohistorical analysis concerning its functions for identity and community building. ${ }^{24}$ This passage

121 David Underdown, Fire from Heaven. Life in an English Town in the Seventeenth Century, New Haven 1992.

122 Simon Böckh, [...] Eine Christliche Erinnerungs- und Gedächtnus-Predigt deß höchstkläglichesten Abbrands/der/deß Heil. Röm. Reichs-Stadt Giengen, Ulm 1655, p. 28.

123 Simon Böckh, Cometarum praesagitio, Ulm 1681. On orthodox Lutheran preachers in Böckh's immediate regional environment, see Norbert Haag, Predigt und Gesellschaft. Die lutherische Orthodoxie in Ulm 1640-1740, Mainz 1992; Sabine Holtz, Theologie und Alltag. Lehre und Leben in den Predigten der Tübinger Theologen 1550-1750, Tübingen 1993.

124 On ars memoriae see Lina Bolzoni, La stanza della memoira. Modelli letterari e iconografici nell'età della stampa, Torino 1995; on more recent disaster history, see Peter Gray and Oliver Kendrick (eds.), The Memory of Catastrophe, Manchester 2004, and for natural disaster in particular, Rohland, Hurricanes in New Orleans, p. 5 of and passim. 
illustrates the fundamental goals the clergy initially had in their roles as disaster preachers: to stress God's intention to castigate.

The second noteworthy point is that the passage contains a rare but interesting use of the word "Sicherheit" (i.e., security/safety) in semantic (rather than morphological) transference from the Latin se-curitas in its original meaning: the concept in Classical Latin from the Epicurean tradition, especially as passed down by Cicero, was understood as a negation of cura, "care." Thus, in a positive sense, it meant "carefree" as tranquillitas animi; in a negative sense it meant the "careless" in the sense of culpable negligence. ${ }^{125}$ In the seventeenth century, following tentative Renaissance forerunners, "Sicherheit" moved in phases from a rare linguistic transference to a sociopolitical guiding principle-initially, in the context of territorial statism. ${ }^{26}$ The above passage from 1665 points to the newness of this semantic development: "Sicherheit" is used not as "security/safety," in its sense as a political guiding principle, but still in its etymologically negative sense, as "carelessness." Indeed, disaster and security — or more precisely fire and security — appear here in a precisely reciprocal relationship, which is the central theme of the current study; however, this point in history reflects the very beginning or even the direct precursor of the incipient epochal development and transformation of this framework.

A Hamburg sermon from 1637 is a representative example which demonstrates how fire and security were bound up in a blending of both the religious function of admonition as well as a new political function related to the production of security in roughly simultaneous but very different ways. At this point there had been several major fires in Hamburg and the magistrate of the city had just adopted the first significant fire ordinance. The head preacher (Hauptpastor) of St. Michaelis, Jodocus Edzard, demanded the authority to

125 John T. Hamilton, Security - Politics, Humanity and the Philology of Care, Princeton 2013; Cornel Zwierlein, "Se-curare, sine cura, se-curitas, assecuratio: Innovationen der Sicherheitsproduktion in der Renaissance," in Gert Melville, Gregor Vogt-Spira, and Mirko Breitenstein (eds.), Sorge, Cologne 2015, pp. 109-35; a similar use with Erasmus, De libero arbitrio $\triangle I A T P I B H$ Sive Collatio Per Desiderium Erasmum Roterodamum, ed. J. v. Walter, Leipzig 1910, IV 16, p. 19o. For quotes matching this observation from the political language around 1600 cf. Hannes Ziegler, "Im Schlaf der Sicherheit. Die Endlichkeit des Religionsfriedens und die Zukunft des Reiches (1606-1618)," in: Christoph Kampmann, Angela Marciniak, Wencke Meteling (eds.), 'Security turns its eye exclusively to the future'. Zum Verhältnis von Sicherheit und Zukunft in der Geschichte, Baden-Baden 2018, pp. $189-206$.

126 Cornel Zwierlein, "Sicherheitsgeschichte. Ein neues Feld der Geschichtswissenschaften," Geschichte \& Gesellschaft 38 (2012), pp. 365-86. 
interpret the meaning of the fires: he delivered a kind of systematic fire homiletics, which essentially asserted the framework of the fire sermons based on the theology of divine punishment popular during the sixteenth and seventeenth centuries, but placed them in close proximity to the practical production of security measures for the future.

Edzard bases his thesis on Matthew 22:7, "The king burned their city." He develops the theme in the following steps:1) How was the fire started? 2) Why did He burn the city? 3) Which signs are given indicating that God would want to set fire to Hamburg? 4) What sort of "fire ordinance" is offered by the scriptures, "so that fire distress is either averted by our city, or if it has already started, that it can be quenched"? ${ }^{127}$ For his first point, Edzard exaggerates a distinction and couples it with Biblical references: God ignites cities partly "immediately" via fire from heaven (Sodom and Gomorrah), partly "mediately," using various means: 1) through soldiers in a legitimate war, 2) through Mordbrenner ("murder burners"; i.e. mass arsonists), 3) through negligence, and 4) through the devil and his tools (which however are naturally empowered by "God's vengeance"). The purpose of fire disasters was therefore to warn and to console, because "it is consoling that it is done by the Lord, who takes away, and then gives again."

Regarding this second point, Edzard is brief and decisive: "Concerning the cause, why the Lord God would set cities on fires, it is simply sin alone." The relevant sins typically included a) not keeping the Sabbath day holy, b) taking the name of the Lord in vain, c) mocking His commandments, d) idolatry, e) falling away from that which is pure and accepting false teachings, f) the injustice of rulers, g) injustice in trade (the attempt to unjustly enrich oneself), h) arrogance, i) adultery and being unchaste, and j) obstinacy against just punishment. As his third point, Edzard asserts that one could argue that these are all punishments from the Old Testament imposed on Jews and heathens and question what this had to do with a Christian city like Hamburg; in response, Edzard subsumes the activities of Hamburg within the categories he established. Denizens of the city, for example, often gambled and drank on

127 Jodocus Edzard, Feuer-Predigt über den Evangelischen Spruch: Text. Matth. 22. v. 7. Der Herr zündet ihre Stadt an. Darinn gehandelt wird, was von denen, in dieser guten Stadt, unlängst leyder oftmahls entstandenen Feuersbrünsten zu halten, und was hinferner zu Abwendung derselben in acht zu nehmen von nöthen sey, gehalten am XX. Sonntage nach Trinit. in der Kirchen St. Michaelis, und auf etlicher Bußeiferigen Begehren in Druck gegeben, Hamburg 1637 [sic], added is: Bernard Vaget, Wahrhaftiger Bericht von dem gräulichen und erschrecklichen Brande des Thurms St. Nicolai in Hamburg [im Jahr 1589] (all together reprinted Hamburg 1750), p. 4f. 
Sunday instead of going to church and were thus epicurean pleasure seekers rather than attentive churchgoers; other sins ranging from adultery to usury also occurred in Hamburg. In addition to these sins, he cites the flood of 1625 (which was followed by an outbreak of the plague) and the flood of October 11,1634 as further portents of the impending incineration of the city. The reported observation of "fire in the sky" as well as destructive fires in other cities also served as warning signs. Finally, he mentions the conflagrations that had already occurred "in many particular houses, which were partly filled with the most precious wares." He condemns the arrogance of the merchants:

As if they wanted to say, why should fire come in our houses, we will simply build more carefully; let the priests' blood boil, in the meantime we will also boil, and cook and fry, and eat and drink good things. Our government and rule will remain intact. Thus, the burned merchant homes are like a boiling pot of the Lord, suggesting what the Lord our God might have in mind for the merchant commerce and splendor of this city: Far be it from us to throw caution to the wind after such signs! ${ }^{128}$

Edzard invokes the recently published fire ordinance of the city magistrate, but then refers to a second, metaphorical, fire ordinance: "In the scriptures the Holy Spirit has also prescribed a good fire ordinance." He goes so far as to compare individual articles: in the "burgher fire ordinance article 6 , it is decreed that designated fire surveyors should diligently make [their rounds] and watch [for fires]." In this way, the Lord God himself goes through the cities as a surveyor of fire; the watchtowers that sound the alarms are like the preachers who warn and admonish on a spiritual level. "Who would mind if the preachers would start blasting the penitentiary trumpets again in these current dangerous times." ${ }^{129}$ The translation and mirroring of spiritual Christian behavior within the newly adopted "fire ordinance" 130 of 1637 is thus one way (albeit in a slightly protesting tone, advocating penitence, church service, and the elimination of the first cause of threatening fire-i.e., sin) of uniting practical and spiritual fire prevention. The fact that Edzard makes reference to the newly adopted fire ordinance here at all shows how he welcomes practical considerations on the one hand, while on the other he wants to couple them with a call to penitence.

128 Ibid., p. 14f.

129 Ibid., p. 17 .

130 For more on this see Ch. 3, 3.1.2, p. 199 f. 
Edzard's sermon, with its etiological systematization and its attempt to make penitence and divine orientation at least as important as activities related to fire policey, is typical for the seventeenth century. Even though ever now and then a document might be found that supports the rhetorically oriented demand of some preacher exhorting city residents to pray rather than fight fires, we should not think that the practical world of fire policey stood in conflict and opposition to the world of religious penitence and the faith of the city's community per se. The opposition always concluded with the admonition that one should pray and put out the fire. ${ }^{131}$ The analysis of the changes within the apparatus of theological interpretation is what is important here.

One might identify a general secularization movement through examining the origins of the modern notion of conscience found within sermons on fires and lightning strikes. ${ }^{132}$ In the sixteenth century, the interpretation of the theology of divine retribution remained absolute and maintained that thunderstormsbeginning with Luther's conversion experience - were sent by God in order to strike the sinner in his moral conscience. Gradually, other interpretations also became viable. The conflict between scientific and theological interpretations of thunderstorms and lightning smoldered in the physicotheological trend dominating the first half of the eighteenth century until lightning conductors were finally implemented, and thus a clear "purely" scientific explanation for the origins of lightning stripped the theological interpretation of much of its legitimacy. ${ }^{133}$ This strictly teleological explication has little relevance as an ideal-type construction, but nonetheless it endures as a framework. One could certainly cite countless solid examples to the contrary, indicating that even in the sixteenth century significant scientific interpretations were already present in sermons and, conversely, that even into the nineteenth century crude tirades invoking the necessity and reality of divine punishment still existed.

In order to contrast the situation of the seventeenth century with a second historical moment period, I will single out one body of work here-the sermons written in $175^{\circ}$ following the lightning strike and ensuing fire which completely destroyed the St. Michaelis Church in Hamburg. Although the fire did not destroy an entire city, the exceptional quantity and quality of these sermons is particularly appealing, in that, like a prism, they reflect a very particular turning point in theologico-philosophical disaster perception, comparable only to the post-1755-Lisbon discussion.

\footnotetext{
131 Cf. Allemeyer, Fewersnoth und Flammenschwert.

132 Heinz D Kittsteiner, Die Entstehung des modernen Gewissens, Frankfurt am Main 1991.

133 Cf. Andreas Bähr, Furcht und Furchtlosigkeit. Göttliche Gewalt und Selbstkonstitution im 17. Jahrhundert, Göttingen 2013, pp. 192-228, who also touches on Brontotheologie.
} 
The fire of the so-called "Michel" church in Hamburg resulted in the largest public discussions about the fear and threat of fire until those after the great Hamburg fire of 1842. On Thursday, March 19, nine days after the lightning strike, the city designated three days after the fires as a special repentance and prayer ceremony for the entire city. Services of worship were to be held in all churches, and the city council strictly regulated the format of the services by stipulating which Biblical texts should be included and which songs from the hymnal should be sung. ${ }^{134}$ Admittedly, this concerted effort towards a major sermon event not only had spiritual purposes, but also served as a means of collecting donations for the reconstruction of the church. Indeed, the very impressive sum of 120,122 Courant Marks was gathered from the collection plates-in total, 439,737 Courant Marks ${ }^{135}$ were donated during memorial collections held every year in March between $175^{\circ}$ and 1765 (Figure 21)

The texts to be included in the sermons to be preached at the first gathering of the Hamburg community in 1750 when these collections were done, were as follows:

1. For the morning sermon (5:00-6:00 am)

Nahum I: 2, 3

2. God is jealous, and the LORD revengeth; the LORD revengeth, and is furious; the LORD will take vengeance on his adversaries, and he reserveth wrath for his enemies.

3. The LORD is slow to anger, and great in power, and will not at all acquit the wicked: the LORD hath his way in the whirlwind and in the storm, and the clouds are the dust of his feet.

2. For the main sermon (8:00-9:00 am)

Amos IV: 11, 12

11. I have overthrown some of you, as God overthrew Sodom and Gomorrah, and ye were as a firebrand plucked out of the burning: yet have ye not returned unto me, saith the LORD.

134 Verordnung [i.e. regulation, edict] wegen des, bey Gelegenheit der, am 1oten Märtz, des 175osten Jahres, durch einen Wetter-Strahl, geschehenen Entzündung des Thurmes zu St. Michaelis [...] auf den 1gten dieses Monats, besonders angesetzten Buß-Fast-und Bet-Tages, Hamburg $175^{\circ}$.

135 At the end of the miscellaneous volume Samlung [sic] der Obrigkeitlichen Verordnungen, Predigten, Gedichte und Kupfer welche bey Gelegenheit der durch einen Wetterstrahl eingeäscherten herrlichen Haupt-Kirche St. Michaelis in Hamburg zum Vorschein gekommen sind [...] (StAHamburg, Bibliothek A 640-77) there are handwritten notes about the successive donation campaigns between $175^{\circ}$ and $175^{2}$. 

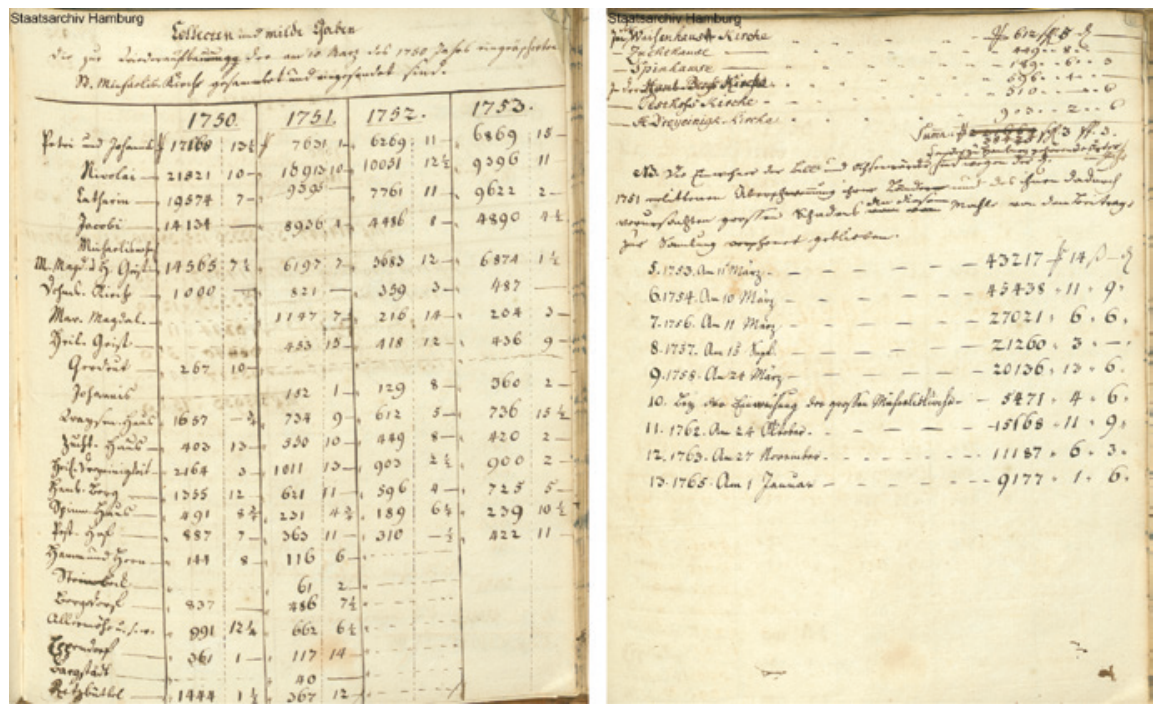

FIGURE 21 Manuscript notes by the church wardens on the sums collected after the destruction of St Michaelis 175 o in Hamburg by lightning, 1753 to 1765 . On the following pages at the end of this volume, we find precious information about the Hamburg collections from 1703 to 1797 for foreign damages, cf. below, Ch. 5, 1.1; HStA Hamburg, Bibliothek A 640-77

12. Therefore thus will I do unto thee, O Israel: and because I will do this unto thee, prepare to meet thy God, O Israel.

3. For the afternoon sermon (2:00-3:00 pm)

Lamentations III: $39-42$

Wherefore doth a living man complain, a man for the punishment of his sins?

Let us search and try our ways, and turn again to the LORD.

Let us lift up our heart with [our] hands unto God in the heavens.

We have transgressed and have rebelled: thou hast not pardoned. ${ }^{136}$

The morning sermon comes from the beginning of the prophecy of Nahum to the inhabitants of Nineveh, that their city would be destroyed; the main sermon comprises the destruction of Sodom and Gomorrah; and the afternoon sermon concludes with a penitence text from Lamentations.

Fifteen sermons by thirteen preachers - the preachers and deacons of the main churches — can be identified. The preachers Friedrich Wagner (1693176o, preacher at St. Michaelis from 1736), Erdmann Neumeister (1671-1756,

136 Verordnung (1750), pp. 8-11 (King James Bible translation). 
preacher at St. Jacobi from 1715), Johann Ludwig I. Schlosser (1702-1754, preacher at St. Katherine beginning in 1741 and the predecessor of Goeze), Ernst Friedrich Mylius (1710-1774, preacher at St. Petri from 1744), Henrich Hoeck (1700-1779, preacher at Holy Trinity from 1729), Christian Friedrich Schaub (preacher at the Pesthof [plague court]), Hinrich Wordenhoff (17091765/66, preacher at St. Pauli) all preached on the main text and also at the most popular times in the churches of St. Jacobi, St. Katharine, St. Petri, Holy Trinity, St. Job (Church of St. Hiob hospital), St. Pauli, and the Pesthof. Only Matthias Lüttmann (preacher at Holy Spirit), the Archdeacon of St. Michaelis (Daniel Rücker), and the deacons preached in the afternoon. All sermon texts were printed as memorabilia, accompanied by poems and historical commemorative texts on the history of St. Michaelis. There were also many other related sermons - for example, the sermon for the construction of St. Michaelis of 1646 , the sermon for the groundbreaking ceremony of 1649 , and the sermon honoring the tower completion in 1669 , accompanied by a description of the July 16, 1589 lightning strike at the St. Nicolai church. In 175o, Edzard's fire sermon of 1637 was even reissued. ${ }^{137}$

In this way the 1750 destruction of St. Michaelis became embedded within Hamburg church and fire history and etched itself into the cultural memory of the city. Through the annual special penitence days held in the Hanseatic city until at least 1765 , the lightning strike of 1750 founded a disaster memory that was fed by a corresponding type of sermon. These sermons anticipated a content and framing that appeared again five years later in the sermons of four Hamburg preachers, Goeze, Mylius, Hoeck, and Zimmermann on the occasion of the Lisbon earthquake. ${ }^{138}$ The fact that the Lisbon earthquake sermons were presented more than four months after the actual event on March 11, 1756, the same date that Telemann's Donnerode (Thunder Ode) was first heard and that

137 Jodocus Edzard, Tempel-Predigt HAGGAI, Erkläret und wiederholet, die Christliche Gemeine in der Newen- oder Vor-Stadt, und andere Christliebende Hertzen anzumahnen dem HERRN Salvatori daselbst sein Haus zu bawen [original date 5 April 1646], reprint Hamburg 1750; Jodocus Edzard, Grundlegungs-Predigt, da der erste Stein zur Neuen Kirchen in der Neuen Stadt Hamburg geleget worden, welche dem grossen Nahmen deß Heil. Michaels, deß GroßFürsten und lebendigen Sohns Gottes, zu Ehren soll gebauet und consecriret werden [original copy 26 April 1649], reprint Hamburg 1750; Johann Surland, Gott ist ein starcker Thurm, und der beste Schirm. Das ist: Eine Christliche Danck-Predigt, aus den Sprüchen Salomonis 18 Cap. Vers. 10. den 9 Martii, Anno Christi 1669. Nach glücklicher Verfertigung des Neuen Thurms an der Kirchen St. Michaelis [...], reprint Hamburg 1750; Edzard, Feuer-Predigt [1637/175o]; Vaget, Wahrhaftiger Bericht [1589/175o].

138 Ulrich Löffler, Lissabons Fall —Europas Schrecken. Die Deutung des Erdbebens von Lissabon im deutschsprachigen Protestantismus des 18. Jahrhunderts, Berlin 1999, pp. 438-554. 
the community of Portuguese Jews in Hamburg set their day of repentance, ${ }^{139}$ is connected to the tradition that began in $175^{\circ}$ of holding a special day of repentance in Hamburg in honor of the lightning-strike. This repentance day was held on the Thursday or Sunday before, on, or after the day of the lightning strike of March 10 (March 7, 1751; March 12, 1752; March 11, 1753; March 10, 1754; March 11, 1756).140 Just as the Lisbon earthquake is later conflated with other catastrophic events such as the Seven Years' War, ${ }^{141} 1750$ was a critical year in the formation of Hamburg's disaster discourse and simply subsumed the later Lisbon memorials.

Whether a specific collection was held for Lisbon's victims is not clear. ${ }^{142}$ Interestingly, other findings in related research indicate that the strongest rise of interest in the earthquake as a scientific object is documented exactly one decade before the 1755 Lisbon earthquake, and that news coverage of regional earthquakes was already well established by that date. ${ }^{143}$ Lisbon was only a catalyst event that fit into an already existing horizon of expectations. Similarly, there is some evidence that Hamburg was at the height of contemporary international scientific developments, while in other German cities there may have been some lag in the reception of ideas and technological innovations such as those reported in Benjamin Franklin's then epochal publications and the subsequent French experiments that occurred two years after the Hamburg lightning strike (in 1752). This is due to the fact that central figures in Enlightenment science had already demonstrated deep interest in the problem of lightning and electricity: Hermann Samuel Reimarus, for example, had conducted

139 Martin Warnke, "Das Erdbeben von Lissabon 1755-eine Bewährung der Aufklärung," Zeitschrift des Vereins für Hamburgische Geschichte 95 (2009), pp. 1-22, 15.

140 Cf. donation entries in St.Michaelis-Sammelband StA Hamburg, Bibliothek, A 640-77, p. 5, 8; see also Warnke, "Das Erdbeben," p. 8 n 15 where he makes reference to the Michaelis fire in the council decision of 20 February 1756 , but otherwise does not mention the date coincidence between the Michaelis fire and the Lisbon earthquake.

141 Ulrich Löffler, "'Gott wollte verschonen, nun tödteten wir' Das Erdbeben von Lissabon und der Siebenjährige Krieg im Spiegel protestantischer Predigt," in Lauer and Unger, Erdbeben, pp. 437-58.

142 Whether a separate donation campaign was held for the Lisbon victims is not entirely clear: In the donation register for 1756 there is only a sum of 22,536 marks courant listed "Für die hiesigen Marschländer nach der hohen Wasserfluth" (StA Hamburg, Bibliothek, A $640-77$, p. 22) and a not precisely categorized sum of 27,021 marks courant for the day of repentance (Bußtag) dedicated to the earthquake, 11 March 1756 (ibid., p. 5).

143 Grégory Quenet, Les tremblements de terre aux XVII ${ }^{e}$ et XVIII ${ }^{e}$ siècles. La naissance d'un risque, Paris 2005, pp. 274, 279f. On earlier parts of the learned investigations and debate about earthquakes cf. e.g. Louis D. Gerdelan, "The Royal Society, Port Royal and the Great Trans-Atlantic Earthquake of 1692," Studi Storici 6o, 4 (2019), pp. 845-874. 
experimental research and collected international news about the topic. ${ }^{144}$ Thus, the impression arises that the Hamburg preachers of the Michaelis fire of $175^{\circ}$ had already largely exhausted their argumentative arsenal when the Lisbon earthquake happened. Of the thirteen authors who preached and wrote in 1750, only three were still active in 1756, in addition to the newly appointed Goeze.

This broader textual basis also invites certain comparisons with Ulrich Löffler's analysis of Lutheran preaching concerning the Lisbon earthquake, which emphasizes that the authors of the Hamburg disaster sermons of 1756 represented four different approaches standing side by side: eschatological, creationist, orthodox, and ascetic. Common to all of them, however, is an antiDeistic, often physicotheological orientation.

144 This comes from a later publication of his son Johann Heinrich Reimarus: after the observation of lightning incidences between 1705 and 1760 the question of whether lightning always strikes in a certain direction, or if it is "different due to various causes" was introduced, and this is a question that the son inherited from his father (Johann Albrecht Heinrich Reimarus, Die Ursache des Einschlagens vom Blitze, nebst dessen natürlichen Abwendung von unsern Gebäuden; aus zuverläßiger Erfahrung von Wetterschlägen vor Augen gelegt [Langensalza: 1769], 39n, see also the lightning strike descriptions

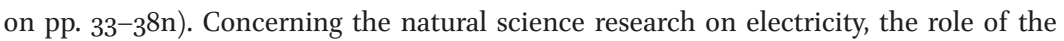
older Reimarus seems to have been ignored heretofore in research. In the Allgemeinen Betrachtungen über die Triebe der Thiere, ed. Jürgen von Kempski, Göttingen 1982 the animal/medical electricity is not mentioned; however from the quotations, it is clear that Reimarus also was familiar with the Hamburgische Magazin, the Philosophical Transactions, and the Histoire de l'Académie with its annual reports of the Académie des sciences. The literature on electricity cited by the younger Reimarus, including the publications in the Philosophical Transactions - there was no interruption in the series of the volumes received from the first decade of the eighteenth century-, were, even during his father's lifetime, consistently integrated into the personal family library. There are indications such as this regarding the exact chronology of the progression of knowledge"[...] since these thoughts have been known in Europe in 1751, it follows that in 1752, Mr. Dalibard and Mr. Delor would begin the first real experiments in France [...]," (Reimarus, Ursache, 72) - thus suggestive of a bio-bibliographical memory and an activity that had been going on for quite some time. In general, it is well-known that Reimarus had a deep understanding of (also called "atheistic") research related to the Newtonian and postNewtonian discussion of physics in the circles of the Royal Society and the Académie des Sciences. On the prehistory and the genesis of his physicotheological Vornehmsten Wahrheiten (1754), see Dietrich Klein, Hermann Samuel Reimarus (1694-1768). Das theologische Werk, Tübingen 2009, pp. 200-66; Ulrich Groetsch, Hermann Samuel Reimarus (1694-1768): Classicist, Hebraist, Enlightenment Radical in Disguise, Leiden 2015 and Id., "The Devil in the Details: The Case of Hermann Samuel Reimarus (1694-1768)," in Martin Mulsow and Asaph Ben-Tov (eds.), Knowledge and Profanation. Transgressing the Boundaries of Religion in Premodern Scholarship, Leiden 2019, pp. 273-296, $282 \mathrm{n}$ 49: Reimarus' interest in magnetic demonstrations by the Dutch physician and mathematician Nicolas Hartsoeker during his Holland travels. 
Friedrich Wagner, the head preacher at the affected Michaelis church, warned at the beginning of his sermon against any suggestions that questioned God's destructive purpose from a theodicean perspective:

I can easily imagine that many righteous souls in our community, which through this great loss ... have been painfully touched and stand deeply bowed, because of the inscrutable wrath of God prevailing here on earth ... or have begun to hold a grudge against God. ... I too am worried, and in part I know that with this great accident others have [opened] their mouths grumbling against God.... O that none should open his mouth against God. ${ }^{145}$

Wagner emphasizes that Amos's comment on Sodom and Gomorrah indicates that even Israel could be directly hit by the fire of the Lord, since fire was specifically created to exact God's punishments. ${ }^{146}$ Wagner then recalls afflictions from recent years: the very hard winter of 1740 , the subsequent lack of grain and the livestock disease epidemic; the subsequent war that arose and the "insecurity of the seas" which suppressed trade; finally, a strong "stormy wind" on December 12-13, 1747. Even though these conditions had all affected other cities and countries as well as Hamburg, the destruction of St. Michaelis was a clear sign of "the burning zeal [of God] for our city."147 It is important for Wagner that it was "God himself" who ignited the fire: lightning was seen simply as an extension of the divine. God specifically chose the newest and the only post-Reformation church. For the first time in the history of the city, and according to Wagner at least until the twelfth century, a major church had been destroyed in a fire. ${ }^{148}$ Wagner nevertheless heavily invokes the still significant

145 Friedrich Wagner, Der gerechte Feuer-Eifer Gottes über Hamburg. Als die neue St. MichaelisKirche den 10 Merz 1750 durch einen Blitz in die Asche geleget war, am ausserordentlichen Buß-Fast- und Bet-Tage den 19 Merz zu St. Marien Magdalenen aus Amos IV. 11.12 vorgestellet: Nebst einigen Historischen Nachrichten, Hamburg 1750, p. 4.

146 Ibid., p. gf.

147 Ibid., p. 12. This was also repeated in the sermon Daniel Rücker, Das durch ein zu Zion vom Herrn angesteckte Feuer zur Buße erweckte Israel wollte zur Erweckung einer hertzlichen Buße, als vorher am 1oten Martii 1750. die herrliche St. Michaelis-Kirche durch einen feurigen Wetter-Strahl entzündet und in die Asche geleget war, an dem ausserordentlichen Buß- und Bet-Tage aus Amos IV. 11, 12. seiner lieben und wehrten Gemeine in der Heiligen Geist-Kirche vorstellen, Hamburg 1750, p. 19; and Johann Andreas Gottfried Schetelig, Die von Hamburg empfundenen Rührungen des Zorns und der Güte Gottes, bey Gelegenheit der am 10. Merz 1750. durch einen Wetterstrahl geschehenen Entzündung und Einäscherung der Haupt-Kirche St. Michaelis, in gebundener Rede erwogen, Hamburg 1750, p. 13.

148 Wagner, Der gerechte Feuer-Eifer Gottes, p. 20: Wagner recalls the major fire of 1684, but emphasizes that no church was affected before or after. The St. Nicolai church tower 
goodness of God even in this act of punishment. After all, due to the simultaneous rain and favorable wind, the fire destroyed only the church; furthermore, the burnt tower fell in an especially benign way, which prevented the fire from spreading to other houses and ensured that nobody died. The fire is a small wound cut with scalpel-like precision from the flesh of the city, which in its precise limitation illustrates the nature of divine will-functioning here primarily symbolically to remind the Deists that God's direct and present intervention is still possible in the here and now in this world.

He then compares the question concerning the significance of the church's destruction to the people of Sodom and Gomorrah through the exegesis of Amos, and asks: "Oh Hamburg! Hamburg! What is now the cause? Why has the fiery zeal of the Lord been kindled upon you, that he has so painfully called you home with fire from heaven?"149 The answer is, of course, the sins of Hamburg, which he further specifies. In particular he cites:

the brash and irrepressible free spirits, the shameless mockers and blasphemers of the Christian religion, indeed the open despisers of all religion and of all God's services: those who reject God's Word and defile or blaspheme the name of Jesus, and who in general want and seek nothing more than to tear all belief in and fear of God from the hearts of all people and to lead an unbridled and unconscienced life; and who also have not refrained from teaching their un-Christian, godless, and abominable opinions against God and His word, not only in societies [i.e., reading groups] to others, but even by spreading their teachings through public writings and printed broadsheets. ${ }^{150}$

Wagner does not specify which writings and which reading groups or societies he means in particular, but one can gather that he probably interprets the lightning strike as a type of anti-Enlightenment divine punishment. The concept of the "free spirit" (Freygeist), also invoked by Joachim Plahn (see below), is probably linked to the idea of "free thinkers," a term that had become a negatively charged epithet—used, particularly in Hamburg, as a specific denunciation

lightning strike of 16 July 1589 only destroyed the tower, not the church; the lightning strike that hit the St. Catherine church tower on 3 March 1622, penetrating all the way to the baptismal font, did not start any kind of destructive fire; while the windstorm of 15 February 1649 knocked the spire off the tower of St. Catherine, the church remained standing.

149 Ibid., p. 28.

$150 \quad$ Ibid., p. 29. 
of Deists and recipients of Deistic thought and loosely linked to the title of Anthony Collins's famous A Discourse of Free-Thinking (1713). ${ }^{151}$ The older Reimarus's Apologie, the "purest" German Deistic original text, which circulated for a long time in hand-written form only and then through Lessing's partial edition, which led to the famous Fragmentenstreit, ${ }^{152}$ cannot be the object of reference here because of Wagner's choice of words: "in published writings printed even here." More generally, he probably had in mind the translation of English writings by Johann Albert Fabricius or the Deistic translation of the Wertheim Bible, first printed in 1735 by Johann Lorenz Schmidt, who lived in Altona and Hamburg with Reimarus in the 1740s. ${ }^{153}$

In any case, Schlosser, the head preacher at St. Katharine's, also used his Michaelis sermon of $175^{\circ}$ against all manner of refutations of the Wertheim Bible and operated on a physicotheological basis, using the various Brontotheologies. ${ }^{154}$ He asked:

151 The German loan-translation first appears in a review of Collins's work in 1714. Christopher Voigt, Der englische Deismus in Deutschland. Eine Studie zur Rezeption englisch-deistischer Literatur in deutschen Zeitschriften und Kompendien des 18. Jahrhunderts, Tübingen 2003, p. 44. The discussion between Toland, Collins, Woolston, and Tindal reaches its highpoint between 1710 and $175 \circ$. On Hamburg as the "center of reception and popularization of physicotheology and Deism" see Johann Anselm Steiger, "Ist es denn ein Wunder? Die aufgeklärte Wunderkritik. Oder: Von Spinoza zu Reimarus," in 500 Jahre Theologie in Hamburg, ed. Johann Anselm Steiger, Berlin 2005, pp. 113-30. There are differing evaluations of the reception of Deism in the literature: Wayne Hudson, Enlightenment and Modernity. The English Deists and Reform, London 20o9, pp. 146-48 emphasizes that its influence was more prominent in Germany than in England; Voigt emphasizes, in contrast, an earlier, purely bibliographic approximation of the reception, which evaluates it as quantitatively immense, but less prominent in its qualitative effect, and becoming even less significant after 1750; for a particular case study, see Jan van den Berg, "English Deism and Germany: The Thomas Morgan controversy," The Journal of Ecclesiastical History 59 (2008), pp. 48-61.

152 William Boehart, Politik und Religion: Studien zum Fragmentenstreit (Reimarus, Goeze, Lessing), Hamburg 1987. On the role of the elder Reimarus's children, such as Johann Heinrich Reimarus, author of the important treatise on lightning cf. note 158; on what concerns the administration of the parental inheritance and the Apologie manuscript, cf. Almut Spalding, "Der Fragmenten-Streit und seine Nachlese im Hamburger ReimarusKreis," Aufklärung 24 (2012), pp. 11-28.

153 Cf. Ursula Goldenbaum, "The public discourse of Hermann Samuel Reimarus and Johann Lorenz Schmidt in the Hamburgische Berichte von gelehrten Sachen in 1736," in Martin Mulsow (ed.), Between Philology and Radical Enlightenment. Hermann Samuel Reimarus (1694-1768), Leiden 2011, pp. 75-101.

154 Johann Ludwig Schlosser, Die Stimme des Herrn im Feuer: am Buß-Tage wegen der durch einen Wetter-Strahl verursachten Einäscherung der S. Michaelis-Kirche in Hamburg zur Erweckung vorgestellt, Hamburg 175o, p. gf.: works of the orthodox Johann Georg Hagemann (1684-1765), superintendent and preacher primarius at Blankenburg, 
Or would we therefore, since tempests can also have their natural origins, deny the presence of the nature's Lord and His government in them? Who created the order of the nature? And who is it that maintains it [nature] in its essence? It is the Lord, who does all of this: Who would deny Him the ability to guide that which His hand has created and which He still maintains, according to His will, in line with His commandments? ${ }^{155}$

Daniel Rücker, archdeacon of St. Michaelis (1692-1773, preacher at the church from 1729) addressed the problem of the relationship of God and nature in the same way: "Of course the works of God within the empire of nature have such qualities that no man can comprehend their very basis with his understanding ... who among us knows and grasps how lightning works, when it strikes and when it doesn't strike; how thunder works." He then adds a footnote, in which the concept of electricity is articulated:

When gunpowder was discovered, one believed that it was now possible to fully explain thunder on the basis of its function. Now with the electrical experiments, one has discovered many new things, also about lightning, as well as thunder, which creates a whole new understanding of thunderstorms. And perhaps neither of these two things can truly clarify the matter for us-perhaps it all behaves still very differently. Quantum est, quod nescimus! John III: 8.156

preacher for the Duke Wilhelm von Braunschweig-Lüneburg-Wolfenbüttel during his travels; Johann Dietrich Winkler (1758-84, became the head preacher at St. Nikolai); of Johann Thomas Haupt (died 1785, Prussian church and school inspector at Templin in der Mark); the Biblical commentary of Romanus Teller, as well as the Cosmotheologischen Betrachtungen of Johann Gottlieb Walpurger (169o-1765), were referred to (see also Löffler, Lissabons Fall, pp. 215-30). Schlosser also quotes (p. 13) Peter Ahlwardt, BrontoTheologie, oder Vernünftige und theologische Betrachtungen über den Blitz und Donner [...], Greifswald 1747; Anders Olofsson Rhyzelius, Brontologia theologico-historica, thet är enfaldig lära och sanfertig berettelse: om åske-dunder, blixt och skott; bestående af fyra delar [...], Stockholm 1721 (a work that offers lightning strike statistics for Sweden's church towers, in particular); Johann Jakob Schmidt, Biblischer Physicus, Oder Einleitung zur Biblischen Natur-Wissenschaft und deren besondern Theilen [...], Leipzig 1731; 2nd ed., 1748, Ch. 7, p. 113f.; Gottlieb Müller, Einige Predigten über verschiedene Materien aus der Naturund Geisterlehre an das Licht [... gebracht], Wittenberg 1749. On the influence of physicotheology in Hamburg, with particular focus on the Derham translation by Fabricus (1730, further editions 1732, 1736, 1741, 1750, 1764); cf. Steiger, “Von Spinoza zu Reimarus," p. 120.

155 Schlosser, Die Stimme des Herrn, p. 12.

156 Rücker, Zion, p. 4. 
Scientific research is defined as a human activity encompassed by a far larger frame of ignorance. Although the younger Reimarus, as a physician and a scientist, followed his father's highly rationalistic path of Enlightenment and did not include any theological reflection in his publication on lightning in 1768 , we find very similar wording here too: "we still have much to learn about the whole nature of the subject of electricity or thunderstorms." ${ }^{157}$ The reference to scientific research on electricity within the sermon as well as the admission of partial ignorance within what was one of the best informed treatises on electricity and lightning in Germany at that time demonstrate that Hamburg was at the forefront of scientific trends - the electrical experiments with the Leiden bottle as well as Franklin's correspondence with the Royal Society about electricity from 1747 were both well-known in Hamburg. From its very first issue in 1747, the Hamburgische Magazin regularly published excerpts from the Philosophical Transactions and from French and Italian scientific publications. ${ }^{158}$ Reimarus's lightning writings were thus based on the steady

157 Reimarus, Vom Einschlag, p. 53. A Socratic topos, to be sure, which in this context, however, had more specifically become a topos of early Enlightenment science in the wake of Boyle, and thus was further developed in the Deism discourse; cf. Jeffrey R. Wigelsworth, Deism in Enlightenment England: The Politics, and Newtonian Public Science, Manchester 20o9, p. 25 f.

158 Concerning the documentation of the ever-present reception of Western European works in Hamburg's Englightenment journals, see Hamburgisches Magazin 1, no. 1 (1747): for example "Nachricht von einigen magnetischen Versuchen" (1744; from Philosophical Transactions 474), pp. 46-351; "Des Abt Nollet Versuch über die Electricität der Körper" (1746; from the Paris printing)," pp. 412-418; "Nachricht von einem italiänischen Werke: Von der Elektricität" (Dell'Electricismo [Venice: 1746]), pp. 154-71; Hamburgisches Magazin 2, no. 2 (1748): "Nachricht von einer Sammlung physikalischer Briefe des Marchese Maffei" (on the theory of the origin of lightning) (Della formazione de' Fulmini [Verona: 1747]), pp. 346-51; "Auszug aus einem Briefe, die Wirkung der Electricität auf Pflanzen betreffend" (i.e., translation of a letter from John Browning to Henry Baker, 11 Dec 1746), pp. 629-31; Hamburgisches Magazin 3, no. 1 (1748): "Schreiben von Kästner an Hrn Joh. Ellicot von der Art die Stärke der elektrischen Ausflüsse abzuwägen" (from Philosophical Transactions 479, 2), pp. 25-29; "Auszug von des Herrn Knights magnetischen Versuchen," pp. 94-103; Réaumur reception, pp. 104-07. The French/English debate on electricity in the years between $1746-5$ o between Nollet, Watson, Baker, Ellicot, in particular, is addressed in John L. Heilbron, Electricity in the 17th and 18th Centuries. A Study of Early Modern Physics, Mineola 1999, pp. 296-304, 309-43 and Paola Bertucci, "Sparking Controversy: Jean Antoine Nollet and Medical Electricity south of the Alps," Nuncius 20 (2005), pp. 153-87. The reception of that debate in Göttingen and Hamburg is not mentioned; on the Hamburgische Magazin, in fact edited by the Göttingen professor of mathematics and physics A. G. Kästner (1719-18oo), cf. Martina Lorenz, "Physik im Hamburgischen Magazin (1747-1767) - Publizistische Utopie und Wirklichkeit," Zeitschrift des Vereins für Hamburgische Geschichte 8o (1994), pp. 13-46, on the editor Rainer Baasner, Abraham Gotthelf Kästner, Aufklärer (1719-180o), Tübingen 1991. 
and uninterrupted analysis of all relevant articles from the journal of the Royal Society, beginning with volume 47 (1750) and extending to Watson's magnet experiments.

Like Wagner, Schlosser, and Rücker, other preachers repeatedly and explicitly emphasize that lightning strikes demonstrated that the "old God, who ruled and dominated this world still lives; that he still has thunderbolts"159; that for all systematic scientific distinctions of fire in the earth's interior, earthquakes through fiery inflammation, volcanos, and fires caused by lightning, the question of who created these fires must always be answered: "God."160 In line with this, Joachim Nicolaus Friedrich Plahn (1724-1787), who worked at this time in Hamburg (1751-1753 private minister for the Duchess of Holstein, preacher at Grabow beginning in 1753), wrote a physicotheological poem for the occasion. In it he presents first the scientific doctrine of the generation of lightning and thunder by rubbing together dense sulfur particles and the capacity this creates to drive fire along air that is rich in potassium nitrate. However, in the end, he emphasizes that Hamburg's punishment was related, above all, to the "free spirit in the art of ridicule/who only mocks hell and heaven", and that God continues to guide natural events, even in individual cases, in the here and now:

He Himself ordered the fates of the world Suffering, fear, and accident

He guides through His limitless gaze

The greatest claps of thunder ...

No fate, that originates from itself

First created that flame

God alone, who is over us all

God alone ignited them. ${ }^{161}$

159 Joachim Johann Daniel Zimmermann, Zwo Predigten nach der am 1oten März 1750 durch einen Wetterstrahl verursachten Einäscherung der Hauptkirche zu St. Michaelis in Hamburg, Hamburg 1750, p. $5^{2}$.

16o Johann Peter Gericke, Der Herr im Feuer wurde der Gemeine zu St. Michaelis, am Palmsonntage 1750. in einer Predigt, nachdem das prächtige Gebäude der Michaelis Kirche durch einen am 10. März erfolgten Wetterstrahl angezündet und bis auf den Grund verbrannt worden, aus Ps. 50, 1. 2. 3. in der Kirche zu St. Marien Magdalenen vorgestellet, und auf Verlangen dem Druck übergeben, Hamburg 1750, p. 20 .

161 Joachim Nicolaus Friedrich Plahn, Das verbrannte Heiligthum Hamburgs. Eine Erzehlung der am 1oten März 1750. durch einen Wetter-Strahl geschehenen Entzündung und gäntzlichen Einäscherung des Thurms und der Hauptkirche zu St. Michaelis [...], Hamburg 1750, f. $\mathrm{C} 2 \mathrm{v}-\mathrm{C}_{3}$ r. 
More so than in the sermons related to the Lisbon earthquake-perhaps because it concerned Hamburg itself, and thus the cause for the punishments could be found in the city - a strong unifying element can be seen here: the Hamburg clergy preached vehemently against Deism. To a greater or lesser degree, lightning was interpreted in the sermons as the manifestation of a "particular providence" (to use more theologically precise terminology) in contrast to the "universal providence" generally expressed through the creation of the world within its natural laws. It was not interpreted as a "miracle," but rather as a discrete action of God, who does not always obey the simple movement of the world according to laws already in place. ${ }^{162}$

It is not possible to identify with certainty a precise group, a text, or an author related to the repeated "free spirit" allusions in the 175 os sermons. It was a term that could be equally applied at this time to anything from materialistic philosophy, such as that of La Mettrie, to various types of Deists. The majority of preachers who published their sermons used the particular lightning bolt to illuminate a narrow distinction between a more traditional physicotheology, in which a place continues to be cleared for God's immediate causation of an event in the here and now, and a more Deism-oriented physicotheology, similar to that of Reimarus and his circle. In any case, the Hamburg Masonic Lodge, founded in 1737, the Spinozaists (in a stricter sense), and more extreme thinkers ranging from radical Enlightenment to atheism, attracted countless opponents who need hardly be named, and were excluded entirely from this distinction that was preached from the pulpit.

Even if there are enduring themes and constants in the theology of punishment, such as the recurring topoi of repentance, penitence, and conversion that were applicable to any catastrophic event from the sixteenth into the nineteenth century, we nevertheless see here a precise functionalization and development of this genre, which can be categorized according to a very specific epistemic and spatiotemporal context. The lightning strike that destroyed the church alone with laser-like specificity was the best possible argument for a conservative-orthodox interpretation of physicotheology, because it could be easily depicted as a precise symbolic speech-act of God, in contrast to the

162 The systematic differentiation, for example, was relatively clearly articulated by Chubb (1738) - see Jeffrey R. Wigelsworth, "'God always acts suitable to his character, as a wise and good being': Thomas Chubb and Thomas Morgan on Miracles and Providence," in Wayne Hudson, Diego Lucci, and Jeffrey R. Wigelsworth (eds.), Atheism and Deism Revalued. Heterodox Religious Identities in Britain, 1650-180o, Aldershot 2014, pp. 157-72, 161. The German, and in some cases Latin, terminology would, of course, be different. Cf. for example, Reimarus's doctrine of predestination in Klein, Reimarus, pp. 234-47 and passim. 
case of Lisbon, which with its undifferentiated obliteration of a huge mass of people, made for a much more difficult argument. Perhaps for this reason, the majority of Hamburg clergy were silent in the face of the Lisbon event.

The Michaelis strike occurred before the publication of Franklin's Experiments and Observations. On August 6, 1767 lightning again struck a bell tower, that of the St. Nicolai church; on February 17, 1768, Johann Albert Heinrich Reimarus pleaded ${ }^{163}$ in front of the Patriotic Society for the installation of a lightning conductor at St. Jacobi. Reimarus was granted his request-against the wishes of the head preacher, Christian Samuel Ulber-but the introduction of this safety precaution met with conflict in Germany, as it did throughout the world. ${ }^{164}$ The Hamburg constellation of the (older as well as younger) Reimarus circles, open to Deism and rationalist physicotheology groups on the one hand, and Lutheran orthodoxy and more traditional physicotheology on the other, thereby replicated in a specific Hamburg milieu the intellectual context in which even the Deist Franklin could witness the spread of anti-Deistic protests in Philadelphia and around the world. ${ }^{165}$ Neither the Europe-wide discussion of theodicy after Lisbon nor the introduction of lightning conductors, however, silenced the preachers of their admonishments and atonements, or to a radical rethinking that would have mandated religion-free explanations of causation or, in the wake of Voltaire, a redefinition of evil in the world as merely a proof against the existence of God.

This new trend can be seen in the fire sermons which were held in memory of the total destruction of Gera in a fire on September 18, 1780. ${ }^{166}$ It becomes

163 Reimarus, Die Ursache.

164 For its diffusion after Franklin and the Marly Experiment see Peter Heering and Oliver Hochadel (eds.), Playing with Fire. Histories of the Lightning Rod, Philadelphia 2009; two local studies: Oliver Hochadel, “'Hier haben Wetterableiter unter den Augsburger Gelehrten eine kleine Revolution gemacht': Die Debatte um die Einführung der Blitzableiter in Augsburg, 1783-91," Zeitschrift des Historischen Vereins für Schwaben 92 (1999/200o), pp. 139-64; Fritz Dross, "Gottes elektrischer Wille? Zum Düsseldorfer 'Blitzableiter-Aufruhr' 1782/83," in Jörg Engelbrecht (ed.), Landes- und Reichsgeschichte. Festschrift für Hansgeorg Molitor zum 65. Geburtstag, Bielefeld 2004, pp. 281-302.

165 Joseph Waligore, "The Christian Deist Writings of Benjamin Franklin," The Pennsylvania Magazine of History and Biography 140, 1 (2016), pp. 7-29: There is ample evidence of these positions for the years $173^{\circ}-35$, while for the late Franklin there was indeed a continuity of the basic notion of a Christianity based on a general natural religion; however, a passage from a letter from 1784 is mentioned, wherein it is made clear that the "miracles of God" in the context of the revolutionary wars, were clearly still relevant (ibid., p. 27f.).

166 Summarischer Entwurf wie der zweyte große Fast-Buß- und Bethtag, welcher Donnerstags den 19 Oct. 1780. In den Hochgräflichen Reußischen Herrschaften zu Gera, mit Singen, Lectionen und Predigten allhier gefeyert und gehalten werden soll, Cuba bei Gera 1780 [Cuba was a small town outside of the Gera walls, not burned, serving therefore in this moment 
clear that certain patterns of reasoning were now barely even possible: all sermons now consistently spoke of the Unglücksfall ("accident")— the German translation of the Latin terminus technicus "casus fortuitus." In the seventeenth century, for Edzard around 1637, there is still no mention of causes of fires other than God. There is talk of the "court of fire" that God holds with people, but not of any classification as simply an "accident," other than in the sense in the sense of "malum." Even in the Hamburg sermons of 1750, the word "accident" hardly appears at all. In 1780, however, the city fire of Gera is consistently described as a "sad accident."167 One can interpret this as an indication of the influence of secular thinking, however, the sermons hardly present a general theodicy debate. Even Johann Friedrich Teller (1736-1816), the orthodox-minded brother of the better-known neologist, ${ }^{168}$ Abraham Wilhelm Teller, went against the tendency described as the "Sadduceean seeing of ghosts" (alluding to Acts 23:8) to explain disasters such as this fire in entirely natural ways.

In any case, the argumentative pattern stands: through such events, the earthly, direct effects of God were tangible and inspired repentance and contrition. In particular, when a fire caused the destruction not only of a few houses,

as place of retreat and printing, it became later part of the city]; Johann Friedrich Teller, Gera in der Asche. Eine Predigt am 18. Sonntage nach Trinitatis 1780, Zeitz 1780; Christoph Ernst Hertel, Die erste Predigt nach dem am 18. Sept. 1780. Ausgebrochenen Geraischen Brand Von dem gottgefälligen Verhalten bey den Unglücksfällen unserer Nebenmenschen, Greiz 1781; Johann Samuel Gottlob Gräf, Predigt am XVIII. Sonntage nach Trinitatis als dem nächsten Sonntage nach dem 18 ten September, an welchem die ganze Stadt Gera durch Feuer verwüstet worden war [...], Cuba bey Gera 1780; Johann Gottfried Senf, Eine Predigt von der ernstlichen Entschlüßung eines unter dem Zorngerichte des verzehrenden Feuers liegenden Volks: am 18. Sonntage nach Trinit. 1780. ̈̈ber 2 Sam. 24, 14. nach dem unglücklichen Brande der den 18. September vorher die ganze Stadt Gera in einen Schutthaufen verwandelt hatte, Cuba bei Gera 1780; Friedrich Wilhelm Streit, Thränen und Entschließungen der Christen bey dem Aschenhaufen einer durch Feuer gänzlich verheerten Stadt. Eine Predigt am 18. Trinitatis-Sonntage 1780 in der Kirche zu Ronneburg bey Gelegenheit des großen Brandes in der benachbarten Stadt Gera gehalten, Cuba bei Gera 1780; Justus Christoph Krafft, Eine Predigt über Luc. 13, 1-5 mit Beziehung auf die Feuersbrunst, welche den 18. Sept. 1780 die Stadt Gera im Voigtlande, in die Asche geleget hat. Nach derselben folgen einige Nachrichten und Briefe, welche diese traurige Begebenheit betreffen, s.l. 1780; Johann Gottlieb Lummer, Ermunterung an die Geraischen Abgebrannten: Jn ihren Trübsalen Gott und ihren Nebenmenschen zu geben, was sich gebühret. Eine Predigt am 23. Sonnt. nach Trin. 1780 in der Gottesackerkirche zu Gera gehalten, Gera 1781.

167 Teller, Gera in der Asche, p. 13.

168 Not 'Neologism' in the sense of coining a new word, but 'neology' as branch of eighteenthcentury German Protestant theology which was foremost characterized by a strong historical-critical approach to the Bible text. 
but an entire city, it was interpreted as directly caused by God: major disasters of the early modern period were clearly His monopoly. ${ }^{169}$ Indeed, there was no need to waste time looking for the immediate causes in this context (in the case of Gera, farmers who carelessly burned pig stalls that had been contaminated by a rampant case of swine disease) because the "mediate causes" were of no consequence-only God, the primary cause, mattered. ${ }^{170}$ The problem introduced by the Lisbon earthquake, that the event involved both the punishment of the guilty and the suffering of the innocent, was addressed, but presented argumentatively, emphasizing that human observers were not in a position to judge whether, for example, the Gera fire justly punished its sinful residents—only God knew how to differentiate the guilty from the innocent. ${ }^{171}$ Johann Samuel Gottlob Gräf explained the phenomenon with the help of a "corporate law" theory of sin: "a city must always be considered as a whole, or as a person." God operates

[as He does] with individual people, not destroying it immediately all at once; rather, He carries [the city] for centuries, sparing it. When $\mathrm{He}$ has warned it enough and spared it enough, the sins are then taken as a whole, finally ripe for judgement, and when judgement falls, [the city] is not only punished for the sins of the people living at that time, but rather for the entire sum of the sins of the city. ${ }^{172}$

The current residents bear what might be described as a medium-term "original sin" or an accumulated collective burden of sin because of the sins attributed to the earlier inhabitants of the city. The main accent of all sermons fell on a focused emotional appeal for sympathy for the victims and the extension of Christian love towards those among them affected by the disaster. Lisbon was never directly named in the sermons because there were ample major disasters to refer to in the vicinity. A quarter of a century later the earthquake might perhaps have caused a rupture in the discourses of major literary works; however, as before, the theology of everyday sermons continued to be based primarily on repentance and divine retribution. In addition to the competing explanatory forces of natural sciences, the other new tendency was how natural sciences became embedded into the tendencies of late eighteenth-century

\footnotetext{
169 Ibid., 2of.

170 Hertel, Die erste Predigt, p. 11.

171 Ibid., p. 16.

172 Gräf, Predigt am XVIII. Sonntage, p. 16.
} 
sentimentalism (Empfindsamkeit) as a secular functional equivalent to religious admonition.

A number of sermons suddenly began to switch to verse form in 1780 and the proportion of "secular" reports, poems, and memorials in the case of Gera seems to have increased in comparison to earlier examples. An anonymous poem sent by "an unnamed humanitarian (Menschenfreund)" from Saxony attempts to dramatize the Gera fire in almost balladlike fashion:

Woe is me! Abandoned and naked I sit walled in by ruins.

The ruins of my fallen fortune [...]

My spirit! Consider the misery—look at the terrifying scene,

The sorrows of an ignited city:

Here a landlord screams in distress, because not far from his head

The smoky flames are reaching toward the heavens.

He calls a neighbor in vain, who, deafened from his own terror,

Does not hear the call of his fearful friend. [...]

There quivers a powerless old man, pleading with a trembling voice

For the help of one stronger;

His call, weak as it sounds, does penetrate sympathetic hearts,

One comes to his rescue.

But, alas! The fire has already filled the narrow passage,

Through which one climbs to his chamber

No man is bold enough to sacrifice his life for a service,

That will not help the old one.

One stands around, wanting to help—not helping — charity fights here

With love of self a harrowing battle. [...]

As far as the eye can see, there is nothing but hungry flames-

They curve terrifyingly down the alleys.

The wind heats up the anger of the fire, already so angry,

And plays with the horrific smoke. [...]

The damage is as great as an ocean-who can bandage these wounds?

With whose sorrow can you be consoled?

Only he-whose compassion knows no limits,

And who remains a father even in his punishment,

Only he devours in his sea of immeasurable omnipotence

Your sea of pain, like a drop.

$\mathrm{He}$ - he shall breathe new life into the dust of your fallen walls!

Rise up anew from the ashes like a phoenix!

Then will return back with words of praise to the bosom of the comforting mother. 
The errant horde of children.

Now hope stirs in my eye-strengthened it sees through the mist Of the dark future, you, Gera, renewed [...]. ${ }^{173}$

While the beginning sounds almost like an Old Testament lamentation, as the poem continues, it emancipates itself completely from this sacred preface and offers a focused subjective perspective, emotionalizing perception on the level of personal experience in an unusual verse form and presenting, above all, the reenactment of terror and suffering. The increasing popularity of such texts in the context of fire disasters indicates a tendency toward the neutralization of catastrophe and the endowment of meaning through empathetic suffering. This was in line with the ever-intensifying trend toward affect-driven poetics as a response to social individualization that had occurred since the age of Sentimentality (Empfindsamkeit). An increasingly sophisticated system of literature obviously begins to fulfill certain functions of religion. ${ }^{174}$

Thus, a transformation in the field of affective-religious security production arises: the city fire shocks the citizens' sense of security on a religious level. In the words of Daniel Rücker: "And thereby they should first find their security disturbed, and be brought to humility before God, which is the beginning of true conversion."175 Similarly, Johann Ludwig I. Schlosser states, regarding the relationship between fire and security: "Because Israel goes forth in its security,

173 Anon., Klagen eines Ungenannten über Gera am 18.ten des Septembers 1780, ed. Friedrich Wilhelm Streit, Altenburg 1781.

174 Poem in Gräf, Predigt am XVIII. Sonntage, p. 19ff.; Lummer, Ermunterung, pp. 54ff.; Anon., Gedanken über den Brand zu Gera, s.l. 178o. Reports and descriptions: Anon., Das Geraische Tabeera oder Beschreibung der erschrecklichen Feuersbrunst welche im Herbst des Jahres 1780 die hochgräflich Reußische Kauf- und Handelstadt Gera ohne alle Rettung völlig in die Asche legte [...], s.l., 1780; Anon., Beschreibung der bedenklichen Verwüstung der berühmten Stadt Gera im Voigtlande [...], Basel 1780 (with several interjections of religious lyrics, pp. 41ff.); Anon., Einige Nachrichten von dem undenkbar grossen Unglück welches die Handelsstadt Gera, am 18. September 1780 betroffen hat, s.l. 1780; Anon., An die hin und her zerstreueten vormaligen Einwohner der durch Feuer zerstörten Stadt Gera und an ein mitleidiges Publikum, Cuba bey Gera 1781; Anon., Gute Gedanken eines Bürgers bey dem höchst traurigen Schicksale seiner geliebten Vaterstadt Gera, Gera 1781; Christian August Behr, Auf das Gera am 18. September 1780 betroffene traurige Schicksal, Cuba bei Gera 1781; Carl Friedrich Uhrlandt, Klagelied eines geraischen Stadtkindes bey dem Verlust seiner Mutter, Cuba bei Gera 1781; Carl Friedrich Uhrlandt, Kurze Beschreibung von dem grossen Brande, der am 18. September 1780. Die hochgräfliche Reußplauische Residenz und Handelsstadt Gera ganz in die Asche geleget hat, Cuba bei Gera 1780; B., Die Größe Gottes in der Zerstörung von Gera zu zeigen und nähere die unglückliche Stadt betreffende Nachrichten [...], s.l.1781.

175 Rücker, Zion, p. 10. 
therefore, says the Lord, continue to do as Israel does!"176 Older and newer concepts of security coalesce in order to provide citizens with a consistent sense of security in their towns and cities-the territorialized concept of political security production begins to merge now with se-curitas, in its positive sense of being "care-free." God becomes a conscience shaker, powerfully evoking the awareness of that which is not self-evident and suggesting the culpable impropriety of such a carefree feeling of safety and security. Through the destruction of the physicality of the city, the feeling of safety and security, which was taken for granted, was also destroyed; religion again reared its head powerfully in the newly opened space of fear. Indeed, to use the metaphor of Edzard's fire policey, the "watchtowers" eagerly champion this space of fear in order to offer a feeling of safety through a spiritual substitute for the lost sense of material security. Fires, like other disasters, start to act as a link between regimes of material and spiritual security. A certain emotionalizing of the impact of perception asserts itself. This phenomenon will be further examined below in the context of images of urban fires.

\subsection{Visualization and Affect}

As has been seen above, sermons, and later, disaster poetics, can be understood as responding to "the reality" of the fire threat, eventually also mirroring, to a certain extent, the higher and lower frequencies in fire trends. On that level, they sometimes even reflect the development of actual safety provisionsranging from metaphorical references, to policey ordinances, to reflections on the newest electricity research of the Enlightenment era. On a different level, they respond to particular development in theology. It would be far too easy to think of that discursive level as simply and passively dependent on and stimulated and shaped by the reality of fire destruction. As is true for all discourses, and for literature and art in particular, specific developments obey their own rules. It is important to note that this relationship of loose coupling also functions in reverse-cohesive congregational calls to repentance and the emotionalized mobilization of Enlightened churchgoers, while certainly not the only decisive factors, were also important factors in the development of disaster management.

On a similar level, this section will explore the correlation between developments in the visualization of major fires and the fire trends that have been identified in the context of the epochal threshold around 1700 in relation to the history of security. The intention here is not to demonstrate the representational

176 Schlosser, Die Stimme des Herrn, p. 19. 
relationship between reality and the image in any simple sense-rather, of primary interest here is an investigation into the function of visualization in the framework of the process that led to the expansion of the aforementioned fire gaps. The beginning of this spread, which can be localized in Europe at an earlier point than that identified by Frost and Jones in America, appears more or less in tandem with what is referred to here as the "normal secure society": a set of conditions ("constellation" in the meaning evocated at the beginning of chapter 4), beginning approximately $1680-1700$, in which natural disasters were conceptualized as exceptions to a counterfactual-normative horizon of expectations-i.e., the idea that towns and cities, even entire territories, were thought to be basically safe (or it was expected that they would be safe). An understanding of how these counterfactual expectations developed can be assisted by an investigation into how major fires were visualized and which developments appeared from the late Middle Ages until the end of early modernity. A special type of disaster-oriented visualization is devoted to the actual result of the disaster-i.e., the scope of destruction, the "ground zero." In terms of ground zero representations, in particular, there is a very direct relationship between visual representations and practical administrative security provisions implemented before and after disasters. I will discuss this relationship at the end of this section as a transition toward the treatment of policey developments of actual pre- and postfire provisions.

\subsubsection{The Modernity of City Fire Images and Their Dutch Provenance}

Art history research specializing in urban fire visualizations-beyond studies concentrating on individual paintings or painters-is limited to a few important works. ${ }^{177}$ Since 2011, conferences have begun to address this subject, ${ }^{178}$ but we are still lacking a thorough study that examines the general

177 Nancy A. Corwin, The Fire Landscape: Its sources and its development from Bosch through Jan Brueghel I with special emphasis on the Mid-Sixteenth Century Bosch 'revival,' PhD diss. University of Washington 1976; Victor I. Stoichita, "'Lochi di foco'—La città ardente nella pittura del Cinquecento," in Ulrich Pfisterer and Max Seidel (eds.), Visuelle Topoi. Erfindung und tradiertes Wissen in den Künsten der italienischen Renaissance, Munich 2003, pp. 439-51; Victor I. Stoichita, “'Lochi di foco.' La ville en flammes dans la peinture des XVIe et XVIIe siècles," in Dimiter Daphinoff and Edgar Marsch (eds.), Das Feuer. Beiträge zu einem interdisziplinären Gespräch, Freiburg in Switzerland 1998, pp. 91-116; Johan Hanselaer, "Aeneas' vlucht uit het brandende Troje. Virtuositeit en Allegorie in de zuidnederlandse schilderkunst van de 16de en van de eerste helft van de 17de eeuw," Gentse bijdragen tot de kunstgeschiedenis en oudheidkunde 28 (1989), pp. 105-18; Vitor Serrão, "O mito do herói redentor: a representação de Eneias na pintura do Portugal restaurado," Quintana 1 (2002), pp. 71-81.

178 Koppenleitner, Rössler, and Tiemann (eds.), Urbs incensa. 
topic of fire motifs and the iconography of city fires for the period between late antiquity and the late Middle Ages-though a contribution on the Sodom motif does exist. ${ }^{179}$

It is important to note that most of the representations of interest for this study lie beyond the material basis of canonical major works of fresco- and oil painting and higher pictorial art. The aesthetic transformations occurring at the apices of the respective developments in art history (which, of course, are always more visible today) only operate as early indicators of new image codes that often took a long time to spread into lower levels of handicraft works of art, which are particularly important for the observation of fire trends. However, at some point, these image codes start to become generally accessible, manifesting themselves in common, practical pictorial forms, such as printed broadsheets, church paintings, illustrations in chronicles, and other minor artworks, including maps and drawings found within administrative files. ${ }^{180}$ Occasionally the reverse cycle of innovation was also at work-for instance, methods of visualizing movement, speed and motion in pictorial art were only later integrated into certain forms of oil painting (see below). In order to make a representative statement about this development, a systematic inquiry was undertaken in state and municipal museums, communal archives, and other cultural institutions in the cities afflicted by fires as registered in the fire database discussed above (Ch. 3, 1). In total, this inquiry involved 1880 cultural institutions. 529 illustrations of 294 fires in 252 cities were collected in an image databank that was made publicly accessible. ${ }^{181}$ Consequently, the following statements do, to some extent, proceed from an analysis of the iconographic developments in higher art and reflect the early development of certain patterns and representational forms. This development will then be contextualized against the

179 Ulrike Koenen, "Die brennende Stadt. Sodom in spätantiken Darstellungen," Actes du Xie Congrès international d'archéologie chrétienne [1986], Collection de l'Ecole Française de Rome 123, 3, Rome 1989, pp. 1355-70.

180 In art history research the distinction between fine art and craftmanship is, of course, a traditional research topic; for the Nürnberg artists see, for example, Martin Tacke et al's prosopography "Der Mahler Ordnung und Gebräuch in Nürnberg": Die Nürnberger Maler(zunft)bücher ergänzt durch weitere Quellen, Genealogien und Viten des 16., 17. und 18. Jahrhunderts, Munich 2001.

181 The database is included as one of the thematic sub-databases into the meta-archive "prometheus", for licensed institutions accessible at http://prometheus.uni-koeln.de/. In order to access the 529 images directly, rather than by cross-referencing them using city names or fire dates, it is neccessary to click on "92 Databases" in the entry portal, and then on the names themselves ("Die Ikonographie der brennenden Stadt"). The work of collecting and corresponding about the images with the institutions was handled in part by Anna Meissner and Max Ammareller, whom I gratefully acknowledge again here. 
background of the great number of low and medium-quality images included in the database. This level of "average"-quality representations is more important for the impact on the development of security production, and, vice versa, the effect of the fire threat and the development of a new standard of safety on the development of visual representations.

In light of this research, it becomes increasingly clear that little visual evidence has been found of contemporary/historical (versus Biblical or mythological) city fires from the Middle Ages, outside of chronicle illustrations: there are always hell fires in the context of the last judgement, or fires in Sodom and Gomorrah, for example, represented in churches, but only very rarely do you see the precisely dateable burning of a neighboring city or the church's city itself beyond representations of wars and sieges. Exceptions can be found-primarily in surviving fresco depictions from the early Italian Renaissance-but this was an incidental, not a prominent motif. ${ }^{182}$ The image of the Frankenberg fire of 1476 is a well-known chronicle illustration, ${ }^{183}$ but there are many other similar depictions. One example of the enduring tradition of chronicle illustration is the watercolor drawing of 1707 in a Mühlhausen chronicle (Figure 22).

The image was placed in the middle of a running text about inflation, the price of grain, and the whitewashing of the Blasius church. The city council's response to the fire itself is also reported: a new regulation was introduced requiring citizens to have their chimneys cleaned every year by a city-sanctioned chimney sweep (previously this aspect of home maintenance was left to the discretion of the homeowners). ${ }^{184}$ Similarly, an illustration of the Mühlhausen fire of 1689 was embedded within the chronicle and characterized as an eye-witness account ("The great fire looked terrifying like this when one stood on the city mountain"). The fact that color images of the fire were included in a chronicle narrative demonstrates the particular significance that visual impressions had in the recollection, and with good reason: the chronicle's description of the measures of the fire policey ordinance in reaction to the fire is thereby tied to the horrific image of the fire and is thus accorded memorial emphasis. On the other hand, since the image is buried in this codex, it did not reach large number of viewers, even in Mühlhausen itself. It almost seems as if people did not want

182 Marco Folin and Monica Preti (eds.), Wounded Cities: The Representation of Urban Disasters in European Art (14th-2oth Centuries), Leiden 2015 have followed the same order and chronology of examples.

183 Gerhard Fouquet, "Für eine Kulturgeschichte der Naturkatastrophen. Erdbeben in Basel 1356 und Großfeuer in Frankenberg 1476," in Andreas Ranft and Stephan Selzer (eds.), Städte aus Trümmern. Katastrophenbewältigung zwischen Antike und Moderne, Göttingen 2004, pp. 101-31.

184 Stadtarchiv Mühlhausen Th. 61/38, p. 318 . 


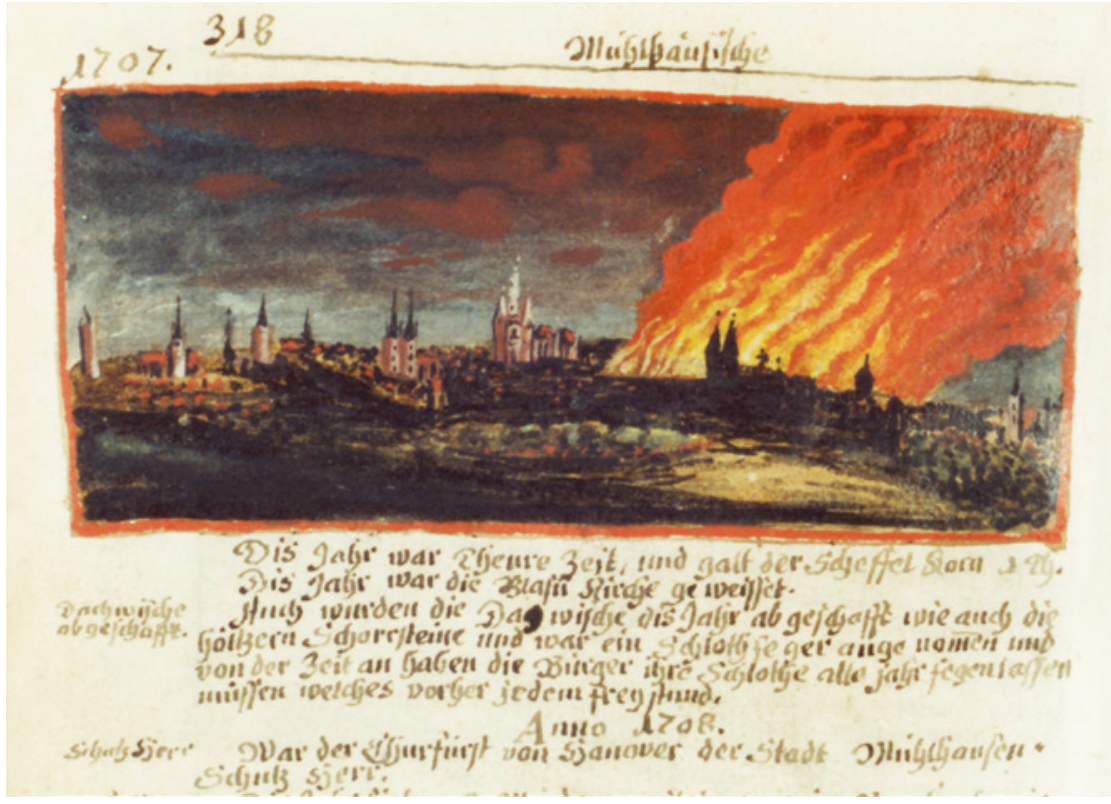

FIGURE 22 City fire of Mühlhausen/Thuringia 1707 in a manuscript chronicle, StadtA Mühlhausen Th. 61/38

to see their own city damaged by fire - an image that would openly reveal the possibility that God had punished them. This great city-destroying event was, on the one hand, revered in the memorialization of city culture, while on the other hand, it was also hidden - banished to the "dark side" of the city's history. This reluctance to depict the fire was manifested in forms of self-censorship, evidenced by the quantity of images in the findings. These invisible barriers of decorum forbidding the representation of such an anti-laus urbis and the destruction of the city were broken down in spurts and starts through the use of various media in the course of early modernity, as will be shown.

The representation of urban fires in oil paintings-i.e., in the highest form of available early modern visualization media-is a subgenre of landscape painting and, as such, a child of modernity. However, scant attention in the relevant literature has been paid to images of city fires or to images of natural disasters in general, which, in part, are not even recognized as belonging to the genre of landscape painting - even though there are very specific defining elements that can be recognized in such works. ${ }^{185}$ If the prevailing

185 See Nils Büttner, Die Erfindung der Landschaft. Kosmographie und Landschaftskunst im Zeitalter Bruegels, Göttingen 2000; Catherine Levesque, Journey through Landscape 
presupposition is true, then like landscape painting itself, paintings of city fires could be considered a primarily Dutch invention that also attracted imitators on the Iberian peninsula in the seventeenth century. The difference from Italian art is striking here. While Raphael and Caracci do not actually depict fire itself in their "fire" paintings, only people (Aeneas/Anchises, fleeing the burning Troy), in this new genre of (natural) disaster painting of Dutch provenance, one finds the exact opposite: in such paintings, fire and flames are the central, exclusive subjects. If Dutch painters did place figures in the foreground, it was invariably in the painting context and technique of "Italianate" work (e.g. Daniel van Dyck, David Teniers the Younger). ${ }^{186}$ Conversely, there was at least one painting that appeared in Italy in memory of the fire in the Venetian Doge Palace of 1577, in which people were not the main subject-unsurprisingly, the painter, Lodewijk Toeput, was Dutch (and it was not a painting of a whole city). ${ }^{187}$

This overwhelmingly Dutch body of works concerning city fires can be quickly summarized in terms of quantity. Nancy Corwin has pointed out that in 10 of the $28-30$ known Bosch paintings, large fire scenes can be seen; ${ }^{188}$ beyond these, the burning of Troy paintings by Lancelot Blondeel ${ }^{189}$ and Adam Elsheimer are well-known. Additionally, there are Gillis Moestart's three Troy fire paintings, ${ }^{190}$ Jan Breughel the Elder's two Troy fire paintings, Pieter Schoubroeck's six fires of Troy and a painting based on the Nero fire of Rome. ${ }^{191}$

in Seventeenth-Century Holland, Pennsylvania 1994; Lawrence O. Goedde, "Naturalism as Convention. Subject, Style, and Artistic Self-Consciousness in Dutch Landscape," in Wayne Franits (ed.), Looking at Seventeenth-Century Dutch Art, Cambridge 1997, pp. 12943. On the topic of city-landscape painting generally see Ralph Andraschek-Holzer, “Topographische Ansichten Österreichs (in den Grenzen der Republik) 1500-180o," in Josef Pauser, Martin Scheutz, and Thomas Winkelbauer (eds.), Quellenkunde der Habsburgermonarchie (16.-18. Jahrhundert). Ein exemplarisches Handbuch, Vienna 2004, pp. $1048-59$.

186 Hanselaer, "Aeneas' vlucht," p. 115 f.

187 Cf. Donatella Calabi, Venezia in Fumo. I grandi incendi della città-fenice, Bergamo 2006, p. 46.

188 Corwin, "The Fire Landscape," p. 51.

189 Hanselaer, “Aeneas' vlucht," p. 106.

190 Hanselaer, “Aeneas' vlucht," pp. 108-11.

191 Margaretha Krämer, "Der Brand von Troja und von Rom-Sieben Versionen von Pieter Schoubroeck," in Edgar J. Hürkey (ed.), Kunst, Kommerz, Glaubenskampf. Frankenthal um 16oo, Worms 1995, pp. 97-102; Martin Papenbrock, “'Das Brennende Troja' in den Bildern von Pieter Schoubroeck. Zur Revision des Vaterlandsbegriffs in Kunst und Philosophie um 16oo," in Koppenleitner, Rößler, and Tiemann (eds.), Urbs incensa, pp. 45-6o. 


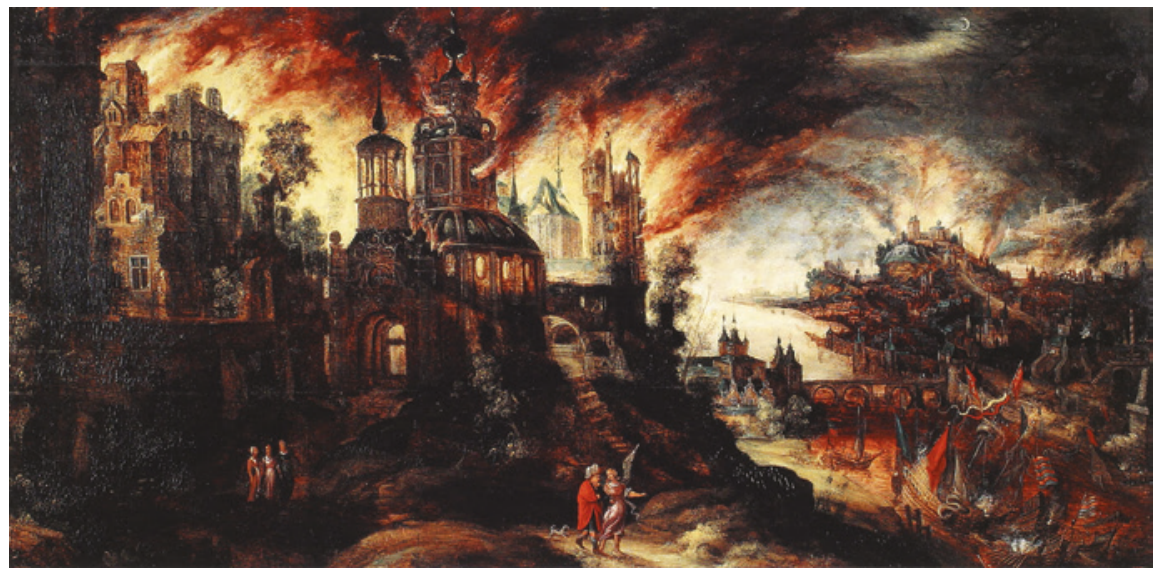

FIGURE 23 Kerstiaen van Keuninck: Lot and his daughters in front of the burning Sodom (ca. 1620), Kortrijk, Stedelijk Museum, Inv. Nr. 924

Daniel van Heil and Kerstiaen de Keuninck painted at least seven fires of Troy and five fires of Sodom (for an example see Figure 23), ${ }^{192}$ Enghelbert Ergo painted four Troy fires and two fires of Sodom, ${ }^{193}$ and Monsu Desiderio painted one Troy fire painting. According to Vítor Serrão, there were also ten Troy paintings by the Portuguese painter Diogo Pereira (who was probably significantly influenced by the Dutch tradition) that position the city skyline, the Trojan horse, and the night/fire contrast quite strongly in the foreground. ${ }^{194}$ When one considers the number of probable lost paintings (for example, the twenty "burning landscapes" that Federico Gonzaga supposedly purchased in 1535, the current location of which is unknown), ${ }^{195}$ the fire motif can be described as virtually mass-produced in the formal sector of oil painting between 1500 and 1650 .

192 Hans Devisscher, Kerstiaen de Keuninck, Freren 1987 (= Vlaamse schilders uit de tijd van de grote meesters, deel 3), catalogs $\mathrm{A}_{3}, \mathrm{~A}_{2}, \mathrm{~A} 24, \mathrm{~A} 26, \mathrm{~B} 45, \mathrm{~B} 46, \mathrm{~B} 47, \mathrm{~B} 48, \mathrm{~B} 49, \mathrm{~B} 5 \mathrm{O}, \mathrm{B} 51$, B52. Five others paintings can be added to this not included here by Devisscher or not attributed by him to Keuninck: Kortrijk, Stedelijke Musea, Inv.Nr. 924—reproduction in Die Flämische Landschaft, 1520-1700, ed. Kulturstiftung Ruhr Essen/Kunsthistorischen Museum Wien (Ausstellungskatalog: Essen, Villa Hügel, 23. Aug.—3o. Nov. 2003), Lingen 2003, p. 319, Fig. 116; Juan Miguel Serrera, Otro, “'Incendio de Troya' de Christian de Keuninck," Archivo Español de Arte 59, 236 (1986), pp. 420-23.

193 Hans Devisscher, "Enkele schilderijen van Enghelbert Ergo," in Arnout Balis (ed.), Rubens and His World, Antwerp 1985, pp. 235-44.

194 Serrão, "O mito do herói redentor," p. 77: Historical sources point to the existence of since lost fire paintings also by painters such as El Greco, Vicente Carducho, and the Hispanicized Flamish immigrants Juan de la Corte, Francisco de Collantes, and Roque Ponce.

195 Corwin, "The Fire Landscape," p. 69. 
There is, perhaps, a very simple reason for the Dutch dominance in this area. One could certainly make the claim that since the modern cities of Italy were more often built in stone, they were therefore less vulnerable to fire, as evidenced by the still largely preserved architecture. ${ }^{196}$ Perhaps Italian painters simply had less personal experience with catastrophic fires than the Dutch. 197

\subsection{2 \\ A Discrepancy: Mythological/Biblical City Fire Paintings vs. the} Low Number/Quality of Paintings of "Real" City Fires

In any case, this reasoning alone is not sufficient to clarify the character of early modern fire representations. There is, in fact, no surviving record of a single contemporary "real" city fire painted in oil by any of the Dutch and Iberian painters specializing in the mythological fire paintings mentioned above, even though there was no scarcity of such events in northwestern and central Europe during the lifetimes and in the immediate environments of these artists. Thus, as "realistic" or naturalistic the Troy and Sodom fires might seem at first glance, they nevertheless always present a fictitious subject. Until the eighteenth century, even the larger fires in Europe attracted often little interest from famous (or even from decent second- and third-rate) painters. While one of the first drawings of Pieter Brueghel concerns the fire caused by the Ottoman warship shelling of Reggio in 1552, there are no such references to current events within his oil paintings. ${ }^{198}$

Is there a deeper reason underlying the rarity of paintings of real (i.e., not Biblical or mythological) city fires and their late emergence, beginning only in the middle of the seventeenth century? The collection and recording of urban fire representations in the image database further confirmed the finding that the number of representations in the early modern period was amazingly

196 D. Ballestracci, "La lotta contro il fuoco (XIII-XVI secolo)," in Città e servizi sociali nell'Italia dei secoli XII-XV, Pistoia 199o, pp. 417-38 at first gives a contrary impression; however, all the major series of fire originate in the Middle Ages, for early modernity there is no comparable attempt at a survey, but reports of large fatal fires in Italian cities are almost nonexistent in the early modern media.

197 But this hypothesis cannot be grounded on firm evidence since Italian urban history has not yet produced a synthesis or representative overview on the reality and frequency of late medieval city fires. For one of the largest Italian cities, see Calabi, Venezia in Fumo, although even for Venice one has to state: "The history of fires in medieval Venice is still to be written" (Kiril Petkov, The anxieties of a Citizen Class: The Miracles of the True Cross of San Giovanni Evangelista, Venice 1370-1480, Leiden 2014, p. 49 n 4). For other cities and territories there is not even as much as a study identifying the gaps in research.

198 Cf. Büttner, Erfindung der Landschaft, pp. 28, 318 (Fig. 4). 
small relative to the modern era, which was particularly surprising considering the precisely inverse relationship regarding the number of fires: almost 8,200 major city fires were situated primarily in the premodern period. In many cases, when a city was affected by a very large fire, there was no surviving illustration at all, even hen the fire was thoroughly documented in local-historical memory. For example, there is no oil painting of the large Erlangen fire of 1706, to which the city owes its present appearance; ${ }^{199}$ there are only engravings or broadsheets illustrating the large city fires of Passau in 1662 and Stralsund in 1678/80; similarly, there are no paintings memorializing the fires in Aalen in 1634, Cottbus in 1671, Offenburg in 1689, or the Nordhausen fires; for the Copenhagen fire of 1728 there is only a copper engraving of the cityscape made in 1717 , to which someone subsequently added clouds of smoke. ${ }^{200}$ This list could go on and on. Concerning probably the largest northern European fire of all, in the 'secret' Finnish capital of Turku in 1827, which destroyed 2,543 houses and burned down a cathedral, only a single post-fire color lithograph has been found. ${ }^{201}$

The paintings we do have can be categorized into different types. One type is an almost paradoxical disaster-idyll, in which the standardized aesthetics of landscape painting and idylls seem strangely overemphasized in light of the disaster that occurred and/or its consequences. Such is the case with some rare, more elaborate ruin/post-fire paintings, such as those related to the Göppingen fire of 1782, by the Ulm city painter Nikolaus Kleemann (Figure 24).202

The total destruction of the city down to the foundations is presented, with wood from broken beams still glowing red. In sharp contrast is the intact front yard and garden belonging to the physician Dr. Gottlieb Friedrich Oetinger. The wall enclosing the yard creates a space of security and tranquility here as if it belonged to another world. Spaces of security and insecurity are sharply

199 Cf. Andreas Jakob, “'Der Ort stieg aus seiner Asche viel schöner empor'—Der Brand der Altstadt Erlangen am 14. August 1706 und ihr Wiederaufbau als moderne Planstadt bis 1712," Erlanger Bausteine zur fränkischen Heimatforschung 51 (2006), pp. 9-47.

200 Kåre Lauring, Byen brcender. Københavns brand 1728, Copenhagen 2003, p. 11; on the fire of 1807, which was, of course, quite spectacular due to England's siege as an act of war, see Thomas Munch-Petersen, Defying Napoleon. How Britain bombarded Copenhagen and seized the Danish Fleet in 1807, Stroud 2007, Fig. 22ff., pp. $138 \mathrm{ff}$.

201 Gustaf Wilhelm Finnberg (1784-1833), After the Great Fire of Turku, 1827, colored litograph, height $35.70 \mathrm{~cm}$, width $55.00 \mathrm{~cm}$. Finnish National Gallery Ateneum-with appreciation to Merja Strandén, Turun maakuntamuseo for her assistance.

202 On the Göppingen fire, cf. Dieter Kauß, "Der Göppinger Stadtbrand vom 25. August 1782 und seine Folgen," Hohenstaufen 13 (1986), pp. 135-55; "Das schöne nahrhafte Göppingen in Asche"-Die Brandkatastrophe von 1782 und der Wiederaufbau der Stadt, [Stadtarchiv Göppingen], DVD, Göppingen s.d. 


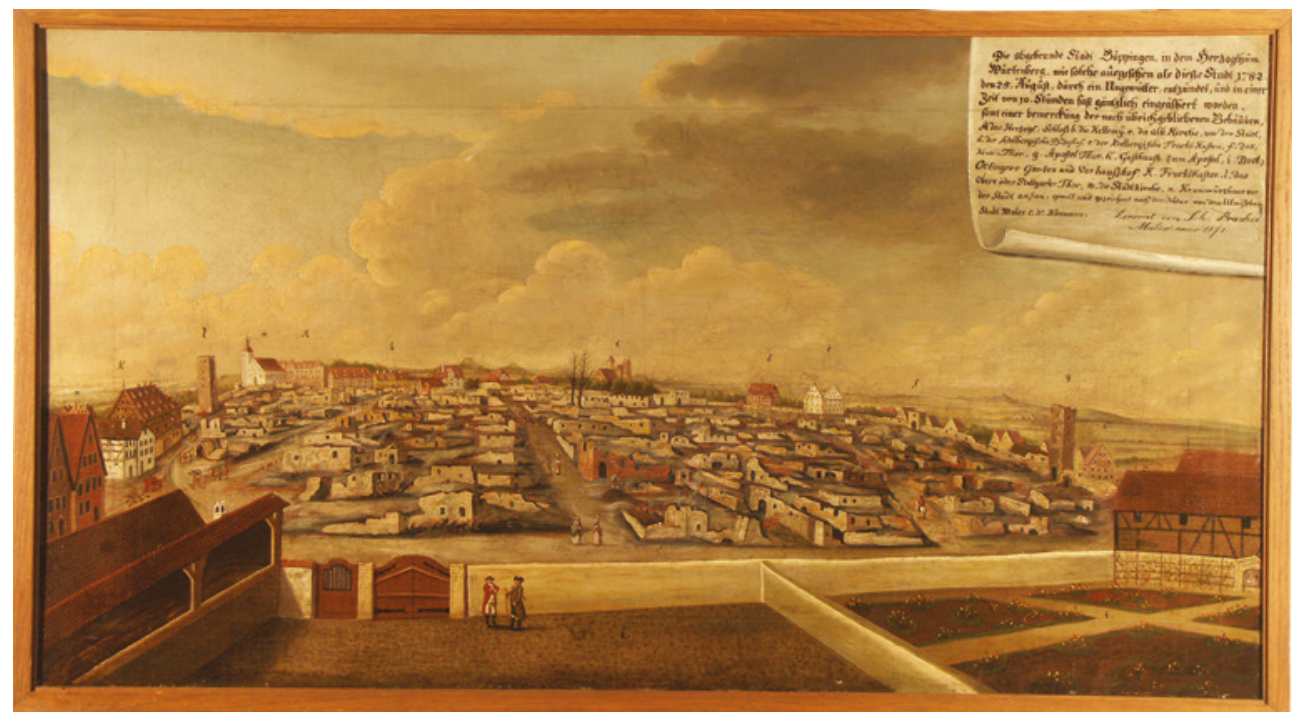

FIGURE 24 Nikolaus Kleemann: Göppingen after the city fire 1782, Stadtmuseum Göppingen

separated by a dividing line. Both areas are deserted, except for a few viewers and others depicted in conversation. The extinction of the city after the disaster is captured in this large-format image: the memory of the potential complete obliteration of the city is emphatically preserved (the painting was carefully restored in 1871). It was created at a time when disaster imagery had already been developed and when paintings of present ruins - not only of ancient ruins - also belonged to the repertoire of European painters.

130 years earlier there are scarcely any representations at all of the fire of Aachen in 1656, the largest early modern German fire before the Hamburg fire of 1842 - nevertheless there is one contemporaneous surviving Dutch school painting (Figure 25). ${ }^{203}$

The representation primarily remains mired in the genre of landscape and cityscapes, which was still relatively new and in which, due to the wide-angle perspective, most people, and even dynamics or movement, play only minor roles. The image shows the city at dawn, with the Lousberg mountain in the background-even this is an idealization. ${ }^{204}$ Were there no flames, this would be

203 On the city fire see Kraus, "Der Aachener Stadtbrand", Fig. 12, p. 6o.

204 The fire took place between eight and nine o'clock in the morning; the sun would have actually been much higher in the sky at this time. 


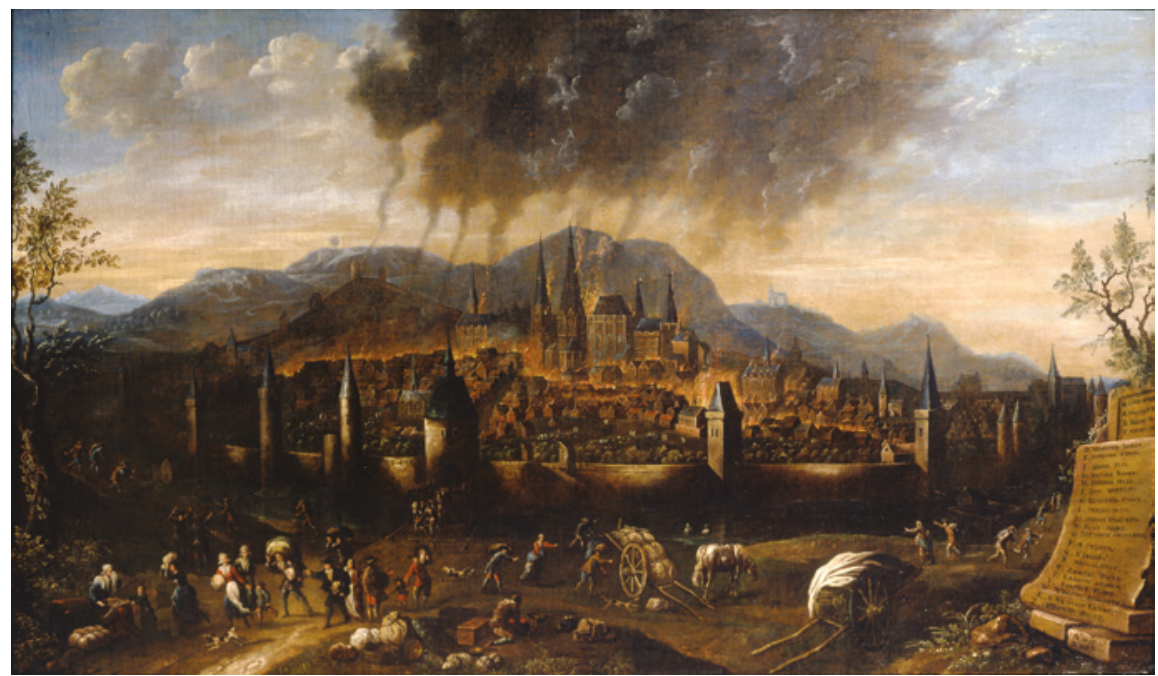

FIGURE 25 City Fire of Aachen 1656, Dutch school, Museum Burg Frankenberg, Aachen, Photograph Anne Gold

a pleasant image showing the city in tranquil peace and beauty with the majestic cathedral in the center and the solid walls in the foreground, so that reverence, quiet strength, and security are expressed. ${ }^{205}$ Through the tongues of fires depicted on top of the houses and spilling down the sides of the cathedral, this painting reverses itself: the strength of the city walls featured in the foreground, which are otherwise emblematic of the security against outside threats, underline here ex negativo only the severity of the disaster inside the city, which is presented as deeply vulnerable and defenseless. The fire seems to draw a line through the city and split it; the town center and the cathedral seem to gather around it, as if the fire almost emerges from there. The dark cloud of fire, fed by impossibly thin curls of smoke, hangs ominously above the city, even though it in no way completely conceals the beauty of the mountain range and the reddish sunlight.

Thus the image captures the reversal of the spaces of security and insecurity at the moment of the disaster: citizens flee the city, rescuing a few possessions

205 The city walls and the fortification of cities were, as is well known, a constitutive element of urban identity and security. Tearing down the walls and the defortification of the cities, responding to new war techniques as well as to new demands caused by the growth of urban population have been major events in the history of many cities. This was addressed already in a famous chapter by Walker, Home Towns and now analyzed for the crucial period of the Napoleonic Wars by Yair Mintsker, The defortification of the German city, 1689-1866 (Cambridge 2012). 
and goods. In the foreground to the left, brightly illuminated people express little obvious sorrow and a woman in the foreground dressed in red and blue with a white apron and holding a child by the hand even smiles. Other than in a park-like area in front of the city, few people can be seen in the city itselfthe protagonists here are the burning main buildings of the city. There is a certain beauty in the whole ensemble and in the color composition, which ranges from dawn-red to fire-orange to the bright darkness of the foreground. It is a dynamic scene: while the fire is front and center, the demise of one of the oldest and most important ceremonial churches in the entire empire occurs more or less in the background. Thus, the demise of the historical is juxtaposed with the departure of individuals. Along the right edge, a legend written in Dutch testifies to the external view on the demise of the ancient imperial city, eschewing any emphatic compassionate subjective perspective. As a whole, the painting shows a borrowing from the natural and city-landscape genre and the bucolic idyll, rather than from the aforementioned mythological fire-disaster paintings.

At almost the same time as the Göppingen painting, a depiction of the great city fire of Gera of 1780 by an anonymous artist (Figure 26) appeared.

This painting is an example of the locus-amoenus tradition and is as similarly undramatic as the Aachen painting: because of the azure sky and the

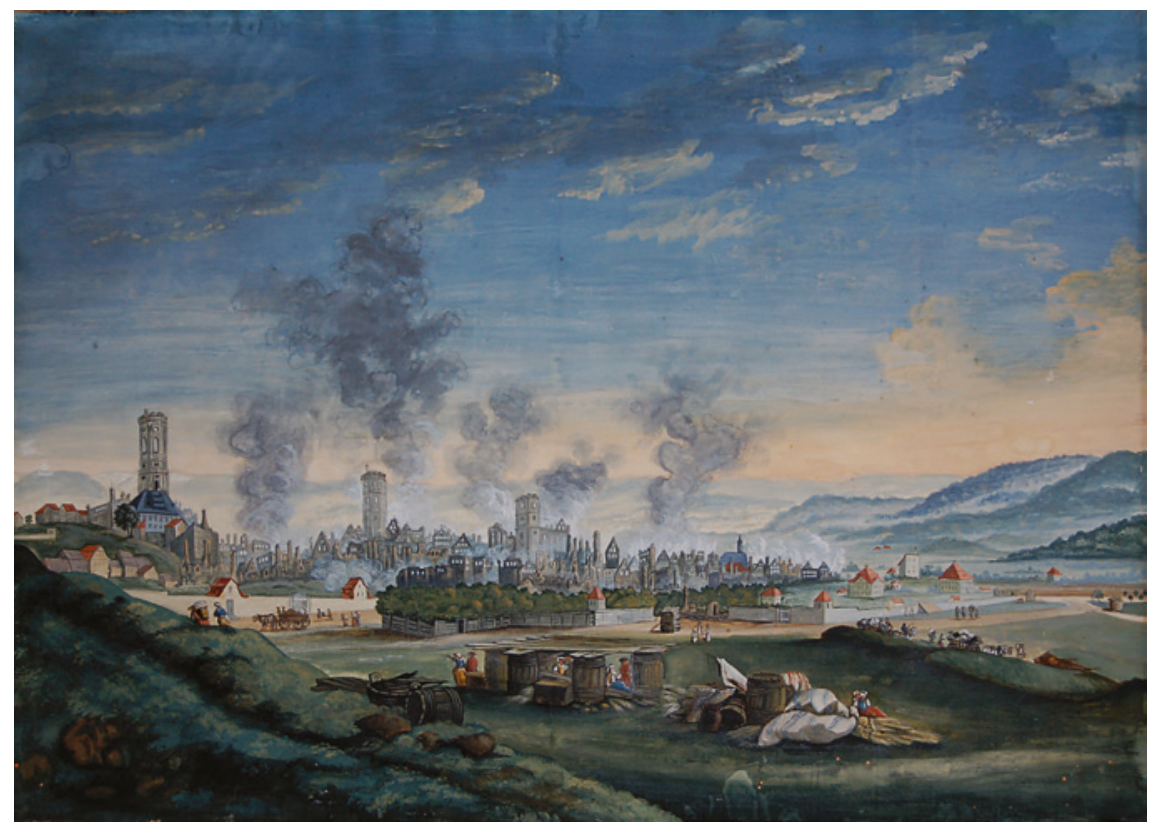

FIGURE 26 City fire of Gera 1780, Stadtmuseum and Stadtarchiv Gera 
fairly innocent-looking clouds of reddish smoke hovering over the city, an impression of tranquillity rather than terror is invoked. Gentle hills are visible in the foreground and a few people are shown with their backs turned away from the viewer, grouped around a makeshift shelter made from barrels and boards, clutching a few rescued possessions. Once again, the viewer is first drawn to the surviving remains of the city: on the right are two infirmaries surrounded by white city walls, which show no traces of the fire; here again one sees the reversal of spaces of security and insecurity as the city of ruins enclosed by the wall is the unsafe space. The disaster is pushed so far into the background of the painting that the ruins actually start to disappear in a bluish haze, so that one must closely examine the painting in order to distinguish it from a normal city silhouette complete with rising chimney smoke. In contrast to the disaster descriptions included in contemporaneous poems and sermons, the viewer here is shielded from the 9,0oo newly homeless residents, from their complaints and suffering. The ruin-landscape painting, intended for extended remembrance, appears to be focused more on contemplation and even on hope, allegorized by embedding the remnants of the city within nature.

The fact that city views like these are considered landscapes follows a pictorial tradition but also suggests the sublimation of the disaster within the idyll. The countermodel to such depictions of disaster denial demonstrates a development in aesthetic processing, first attempted, as has been shown, by the Dutch around 1600, but only in respect to mythological images of fire: there are two anonymous paintings of the major Goslar city fires of 1728 and 1780 that esteem night-time fire representations as evidence of virtuosity (Figure 27 and 28).

The dark image dominated entirely by fire-red is something of a secularized representation of hell-no devil figures emerge, but the urban landscape painted entirely in black, the red reflection on the faces and bodies of the people in the foreground, and the pale yellowish-edged moon on the borders of the image, convey an unvarnished impression of hopelessness and helplessness. In contrast to images like the Aachen painting, the people in the foreground are also clearly in a state of fear and panic-many are depicted in the foreground on their knees offering prayers toward heaven. The painting itself avoids a strongly religious interpretative framing, its caption records only the time and range of the destruction, and the victims in prayer are depicted rather objectively, lending a distanced perspective to their great consternation. The disaster and its effect on the people remains as if caught in an illustration of an experiment. A place of safety is not seen in this image at all—the fleeing people do not find themselves beyond this disaster; 

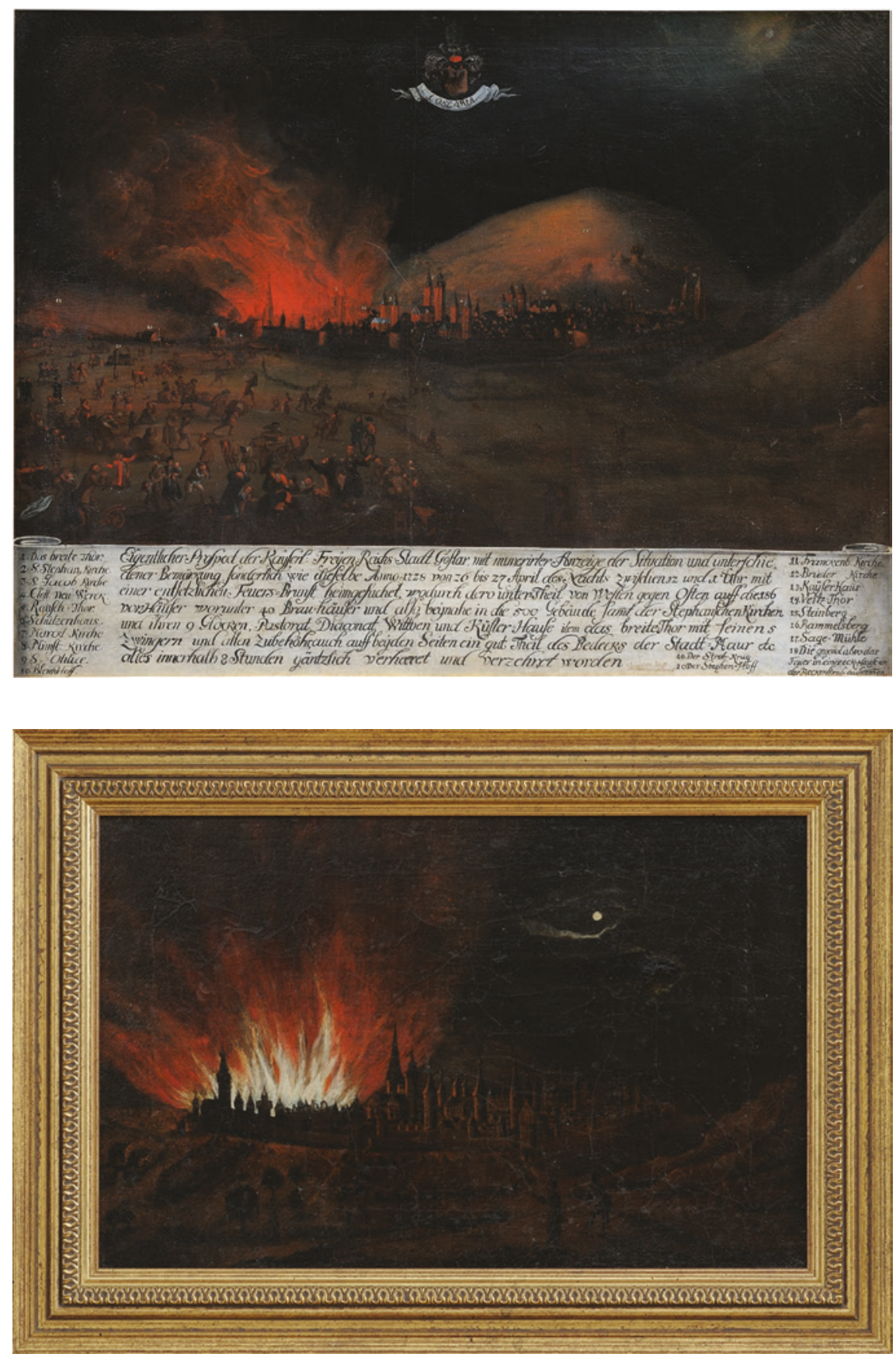

FIGURES 27 AND 28 City fires 1728 and 1780 of the Free Imperial City of Goslar,

Oil $34 \times 23 \mathrm{~cm}$ and $113 \times 87 \mathrm{~cm}$, Goslarer Museum, photography:

Bernhard Heinze 


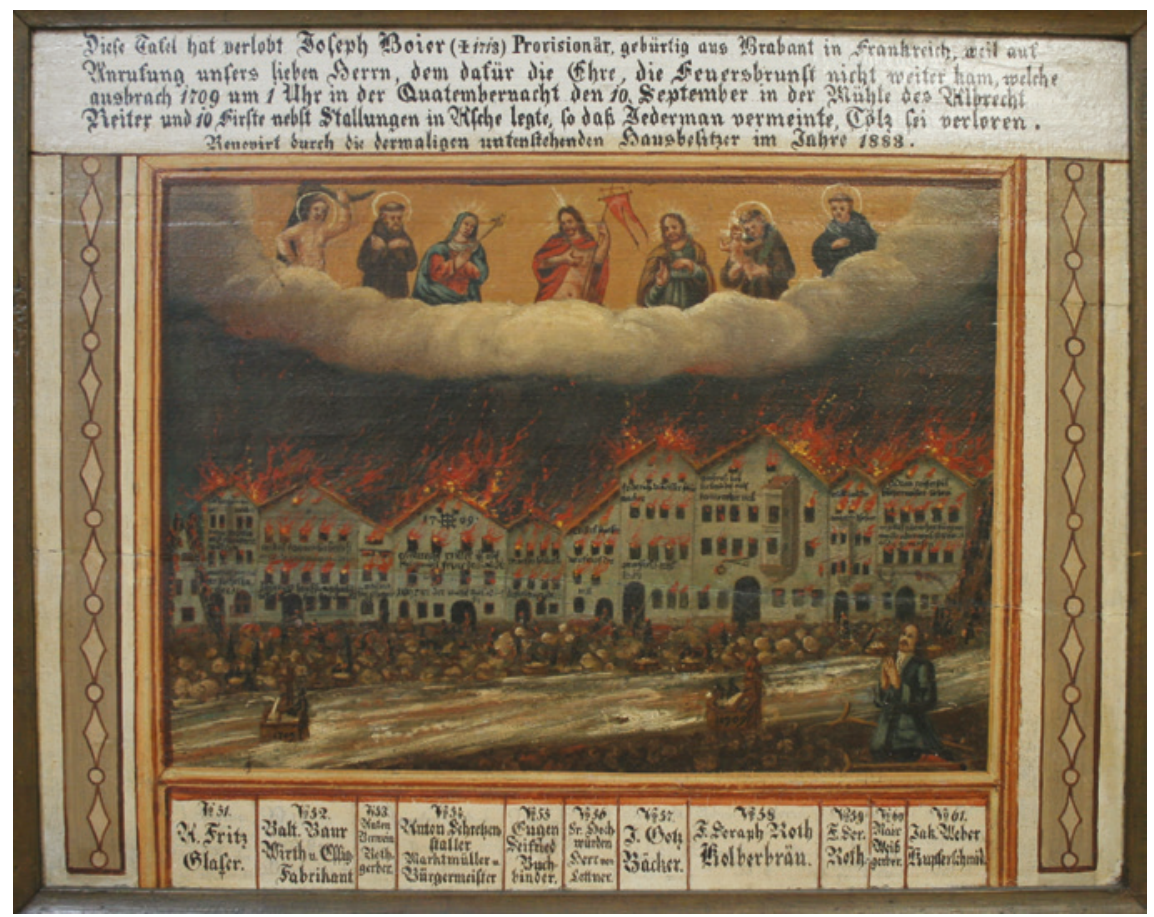

FIGURE 29 Votive picture in memory of the 1709 fire of 11 buildings in Bad Tölz, Leonhardikapelle Bad Tölz (property of the church foundation Maria Himmelfahrt Bad Tölz, photography: Claus Janßen)

they have, perhaps, outrun physical death, but cloaked in the dark of night, now as before, they are part of the disaster situation. ${ }^{206}$

Compared to these rather rare oil paintings, composed with care and craftsmanship, votive paintings become fairly common in the Catholic arena beginning in the sixteenth century - for example, the Bad Tölz image (Figure 29) of the house fires of 1709, featuring a precise depiction of the homeowner with

206 The caption states: "Eigentlicher Prospect der Kayserl: Freyen Reichs Stadt Goslar mit numerirter Anzeige der Situation und unterschiedener Bemärkung, sonderlich wie dieselbe Anno 1728 von 26 bis 27 April des Nachts zwischen 12 und 1 Uhr mit einer entsetzlichen Feuers=Brunst heimgesuchet, wodurch dero unter-Theil von Westen gegen Osten auff die 186 vor-Häuser worunter 40 Brau-Häuser und also beynahe in die 50o Gebäude sammt der Stephanschen Kirchen und ihren 9 Glocken, Pastorat, Diaconat, Wittben und Küster-Hause item das breite Thor mit seinen 5 Zwingern und allen Zubehöhr, auch auff beyden Seiten ein gut Theil des Bedecks der Stadt=Maur etc alles innerhalb 8 Stunden gäntzlich verhaeret und verzehret worden." 
Mary, Christ, and five saints hovering above him. The sponsor was not one of those affected by fire, but rather Joseph Boier of Brabant, whose house had been narrowly spared. This image also bears a notice of restoration in 1888 , which had been financed by the current residents of the once-burned house. The fire was thus maintained in the collective memory.

There are many such instances which suggest a heightened interest in conscious memory work at the end of the nineteenth century. ${ }^{207}$ Votive paintings are mostly found in churches or in local museums and primarily serve local memory, the historical remembrance of the respective city, or local Mary or Florian worship. There are also city fire memorial images found on the target plates of marksmen guilds - a rather unexpected motif. For example, a Feldkirch target plate from 1697 depicts the city fire that had just taken place and the annual winners of the shooting festivals were engraved on the edges (Figure 30). A similar plate of Mittweida 1793 shows how, 100 years after the large city fire of 1683 , the shooting festival was devoted to the memory of that catastrophe (Figure 31).

The center of the image, depicting the city fire, shows the arrow shot marks. Sometime every year, and sometimes just in a special year of commemoration, there was a target shooting in (dis)honor of the city fire, which must be interpreted as an apotreptic gesture, a gesture of survival, recovery and re-empowerment ex-post in eventually remarkable conviviality. The often poor quality of these local fire images also weighs on and partially reduces their ability to invoke emotions of terror, fear, and disaster angst related to the fire: while traces of such fear are evident in the Biblical and mythological fire images, they also appear-as will be shown below-in other visual media of the time, and particularly in printed broadsheets and engravings.

After the relative absence of city fire illustrations in the Middle Ages, various types of images arose in early modernity - even in oil painting, which, on the one hand could communicate the virtual negation of the disaster within the idyll and the depiction of remaining safe places (e.g., nature, new vast spaces, and hope for the future), but on the other hand, could also portray the hopelessness and the absolute nature of the disastrous moment from a superhuman perspective. Votive and memory images, especially (but not only) in Catholic areas, also flourished during this time. Overall, there seems to be

207 This is also the case, for example, for Bieberach/Rieß, Bobingen, Braunau, Giengen/Br. [Neubronner Epitaph], Hechingen, Klosterneuburg, Knittelfeld, Oberndorf 1757/Laufen 1864, Murau. 


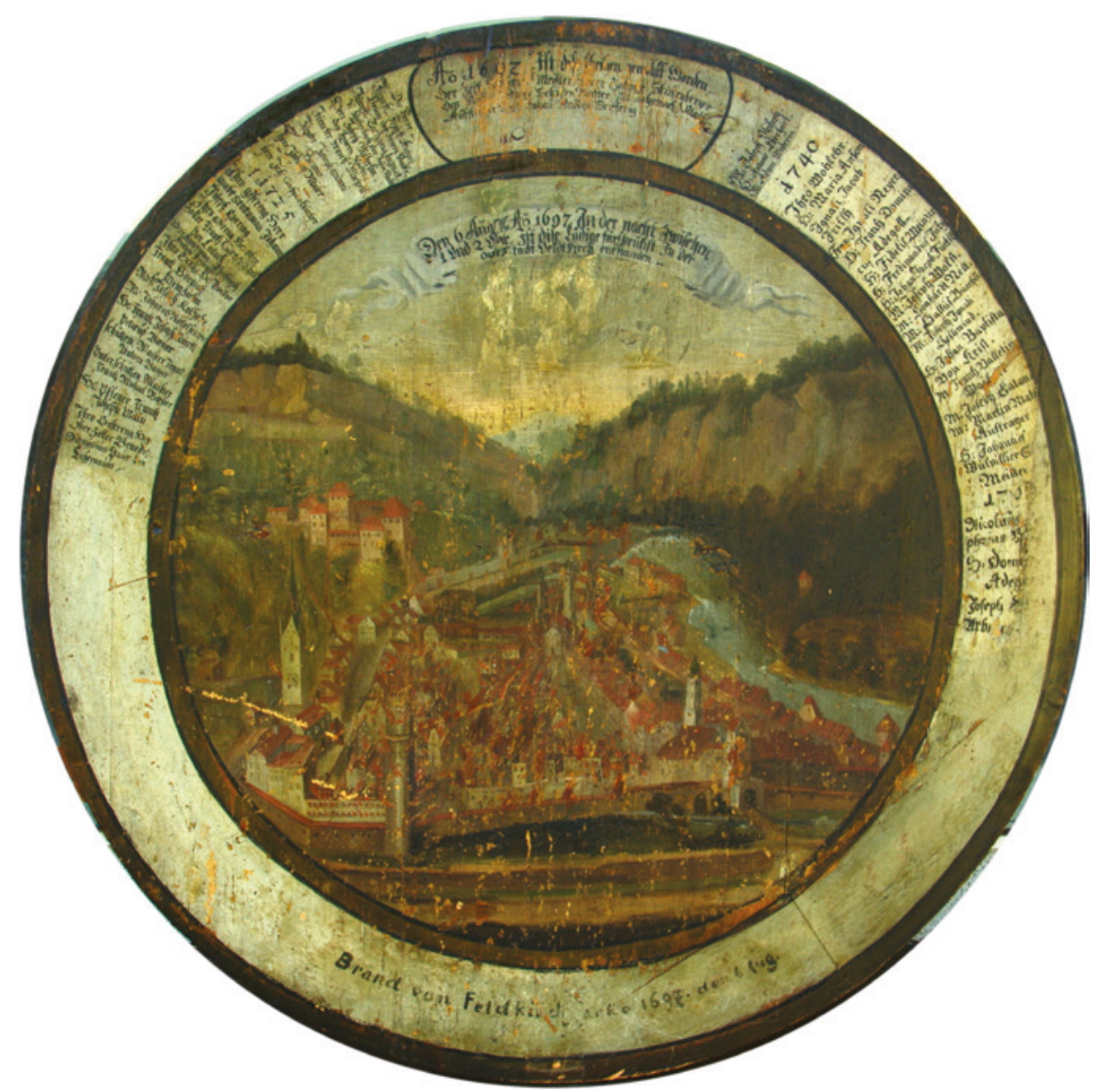

FIGURE 30 Feldkirch target plate (Schützenscheibe), Fire of 1697 (Property of the Hauptschützengilde Feldkirch, reproduction by kind permission of Oberschützenmeister Mathei)

a glaring disparity between the number of elaborate Biblical and mythological city fire images in Dutch painting between 1600 and 1650 in comparison to the very limited number of paintings devoted to real fires. Excluding, perhaps, images devoted to the London fire of 1666 (the most famous of which were painted by Jan Griffier), ${ }^{208}$ if such oil paintings are found, they are almost invariably painted by a relatively unknown artist, or otherwise escape the attention of art history.

208 Cf. the contibutions of Koppenleitner and Heyl in Koppenleitner, Rößler and Thimann (eds.), Urbs incensa. The Museum of London has devoted a whole section and website to the event in 2006: http://www.fireoflondon.org.uk/. 


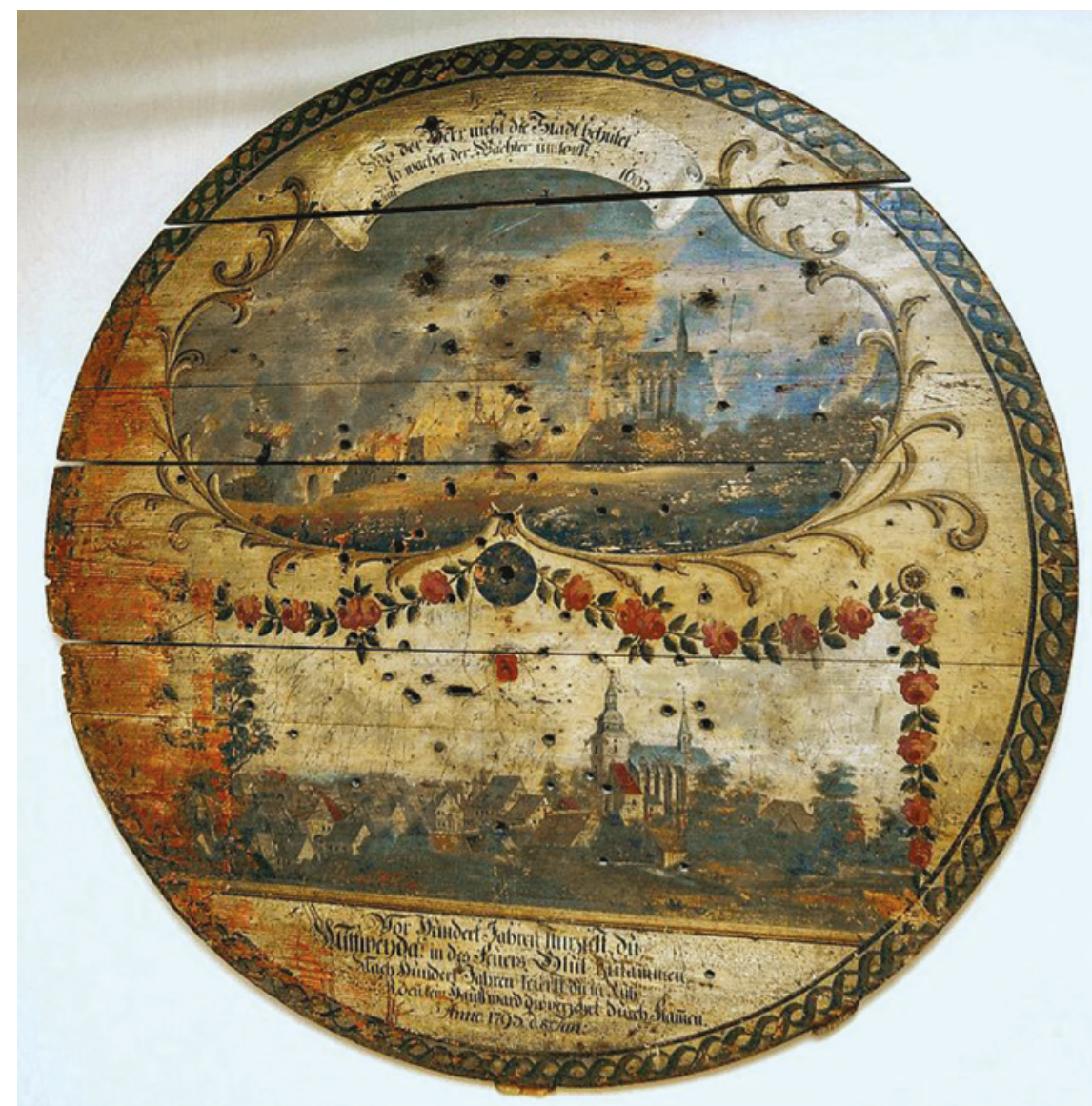

FIGURE 31 Burning Mittweida from south-east on a target plate (Schützenscheibe), oil on wood, diameter: $169 \mathrm{~cm}$, Stadtmuseum Mittweida

\subsubsection{Early Modern Image Theory and Disaster Images}

There is thus a strange distance between the representational realism of mythological or Biblical locations versus the underrepresentation of real medieval city fires in paintings and the idealization of disasters, as if representing them was considered somehow inappropriate for this upscale medium. At this point, a rereading of contemporaneous image theory, beginning with Cristoforo Sorte, could be of further help; as Victor Stoichita points out, Sorte was the first theorist of fire representation and one of the few who dealt with this topic at all in early modern painting theory.

According to Stoichita, beginning with Erasmus, art theory classified fire and burnings within Pliny's notion of "the unrepresentable." Sorte was the first 
to incorporate the unrepresentable into the context of theoretical reflexion. According to Sorte's conception of a city fire image, "nature alone makes the 'story' rather than the [human] figures." Thus in comparison to classical painting, there is a "complete upheaval of the concepts: the background (nature) becomes the main character, while the figures (the mass of Veronese citizens in the fire image described by Sorte) are transformed into the background."209 When he then brings up as a counterexample the figure-centric Italian tradition of the Troy fire representation in the form of Raphael's Incendio del Borgo, he invokes the first unexplained curiosity: why should an Italian, rather than a Dutch theorist be the first to reflect upon city-fire landscape painting? Let us therefore consider again the Osservazioni nella pittura and its author.

While, as is well-known, Sorte was a pupil of Giulio Romano, he was also a cartographer, geographer, chorographer, and architect. ${ }^{210}$ In fact, there are no surviving oil paintings by him; ${ }^{211}$ however, there are seven larger maps and seventy-four cartographical-chorographical landscape drawings attributed to him. He had written the Osservazioni because a nobleman from Desenzano del Garda, Bartolomeo Vitali, asked him for further clarification of his painting methods - a request which was related to the reflections on a "corografia" that Sorte had given him. It is not known if Sorte worked for Vitali, as he did for many other "private" noble clients, as well as monasteries, bishops, and the Signoria herself in the surveying and drafting of the many small territories and places in the terraferma - but he probably did. ${ }^{212}$ This was obviously a (not surviving) $)^{213}$ "descrizzion del Veronese," as it was later called, and in it Vitali

209 Stoichita, "Lochi di foco, 448.

210 Cf. Jürgen Schulz, "Cristoforo Sorte and the Ducal Palace in Venice," Mitteilungen des Kunsthistorischen Instituts in Florenz 3 (1962), pp. 193-208; Jürgen Schulz, "New Maps and Landscape Drawings by Cristoforo Sorte," Mitteilungen des Kunsthistorischen Instituts in Florenz 20 (1976), p. 107-Italian translation of these essays: Jürgen Schulz, La cartografia tra scienza e arte: carte e cartografi nel Rinascimento italiano, Modena 2006, pp. 91-140. See also the newer collection: Silvino Salgaro (ed.), Cristoforo Sorte e il suo tempo, Bologna 2012 which examines the Sorte's background from many perspectives.

211 Cristoforo Sorte, Osservazioni nella pittura, in: Paola Barocchi (ed.), Trattati d'arte del cinquecento fra manierismo e controriforma, vol. 1, Bari 196o, pp. 271-301, 276 n 1 .

212 On Sorte's clients and on his way of working see the study on the archival tradition at this point by Silvino Salgaro: "Conoscere i luoghi senza leggere le lettere de' loro nomi.' Cristoforo Sorte cartografo," in Salgaro, Cristoforo Sorte, pp. 305-52, 309-14. This contribution also contains information about Sorte's surveying techniques, his notation techniques, and his impact.

213 Denis Cosgrove, "Prospect, Perspective and the Evolution of the Landscape Idea," Transactions of the Institute of British Geographers 10 (1985), pp. 45-62, 52: "The work that Vitali refers to is sadly unknown." 
already admired the craftsmanship with which Sorte painted the "incendii." Taking the comments of Sorte and Vitali together, it is evident that in his Osservazioni, Sorte always had his own work in mind as the object of commentaryi.e. the watercolor chorograph that he gave to Vitali, identified by Cosgrove on the basis of its description as "part-map, part landscape drawing."214 Supposedly, this chorograph contained an illustration of the Verona fire of $1541 .{ }^{215}$

This "private" chorograph is said to be yet another side project in addition to Sorte's main occupation at the end of the 1570s (Vitali's letter dates to 1578): the manufacture of six chorographs (maps of the Venetian terra ferma) for which he was commissioned in 1578 by the Sala della secreta for the Doge's Palace in Venice on the occasion of its reconstruction after the fire of $1577 .{ }^{216}$ Some similar watercolor maps by Sorte still survive. Stoichita's comments on the pictorial topos of the burning city on the basis of Sorte's work thus appear somewhat misleading: Sorte does not stand in the tradition of those theorists who, like Varchi quoting Pliny, conceive of fire as "unrepresentable;" rather, he is aligned with those who revived the artistic and simultaneously technical surveying description and collection of countries and cities, particularly Venice, after the rediscovery of Ptolemy's Geography/Chorographie. ${ }^{217}$ The chorographic was thereby the qualitative descriptive element that completed geography, and thus also counted as the storia of the country. In this way it is not surprising that Sorte believed that a decisive event in city history, like the Verona fire, belonged to the corografia and should be represented as such. From this perspective, it becomes clear why Sorte coupled his Osservazioni in the second edition of 1594 with a medieval chronicle of Verona. Written and painted storia-descriptions of space and time-intermingled in chorography as qualitative descriptions of the place.

214 Already in Cosgrove, "Prospect;" also see Denis Cosgrove, The Palladian landscape. Geographical Change and its Cultural Representations in Sixteenth Century Italy, Leicester 1993.

215 Cf. Bartolomeo Vitalis's letter to Cristoforo Sorte, written in Desenzano [at the Garda Lake] on 28 February 1578, in Sorte, Osservazioni, p. 275 f.

216 Gian Maria Varanini, "Governo del territorio e raffigurazioni cartografiche. La Terraferma veneta tra Quattrocento e tardo Cinquecento," in Salgaro, Sorte, pp. 87-107, 106f. He places Sorte's chorographic activity within the then 150 -old Venitian tradition of creating a visual record of the successively conquered areas of the terraferma for administrative purposes, with reference to the rich tradition of determining borders, including the diverse relazioni and the related military defensive and fiscal purposes of tax extraction.

217 Instead of multiple references, see: Numa Broc, La géographie de la Renaissance (14201620), Paris 1980; Marica Milanesi, Tolomeo sostituito. Studi di storia delle conoscenze geografiche nel XVI secolo, Milan 1984. 
His image of the Verona fire of 1541, which has not survived, was one of many documents and memorial images, preserved in local historical sources; typically, better painters did not choose this subject for elaborate paintings. In any case, Sorte does briefly argue at the end of this textual passage that past and mythological city fires such as those of Troy or Corinth should also be painted in just the same way. ${ }^{218}$ This short note is remarkable, because it succinctly bridges the disjunction expressed at the beginning of this section between realistic representations of fictional fires and the underrepresentation of real fires in paintings: Troy fire representations thereby reflect real fires, which means conversely that, according to Sorte, representations of mythological city fires should basically be read chorographically.

Sorte's categorization of such images in the chorographic tradition suggests city fire painting as a distinct subgenre of landscape painting, and thereby connects it to the older discussion (related to Svetlana Alpers' compelling argument) emphasizing the affinities between Dutch painting aesthetics with chorography and with the new scientific methods of the sixteenth- and seventeenth-century world. ${ }^{219}$ While the structures of Troy, Sodom, or Rome presented in the fire paintings are fictitious, the important consideration was to make the representation of the fire "seem real."220 However, a secret message was rarely coded into a second level of meaning. ${ }^{221}$ At the most, a certain generalization was intended: the representation of the fictitious town stands for the city fire in itself, for the phenomenon known to all, for the fire of every city. There is no strong religious or moral emblematic meaning accorded to the paintings and a punitive God is not the represented, even in paintings of Sodom. Instead, Sodom and Troy are almost interchangeable - they represent the structure of the breathtaking tragedy of the outright destruction of a city through flames and the ensuing forced flight of the denizens of the city. Dutch paintings, such as those

\footnotetext{
218 Sorte, Osservazioni, p. 292.

219 Svetlana Alpers, The Art of Describing: Dutch Art in the Seventeenth Century, Chicago 1983, esp. 119-68.

220 Eddy de Jongh, "Realism and Seeming Realism in Seventeenth-Century Dutch Painting [1971]," in Franits, Looking at Seventeenth-Century Dutch Art, pp. 21-56, 28: "They are nonexistent landscapes that nevertheless could have existed" (not in relationship to moving fire images). Cf. also Eddy de Jongh, Questions of Meaning: Theme and Motif in Dutch Seventeenth-Century Painting, trans. and ed. Michael Hoyle, Leiden 200o, pp. 167-91.

221 Even de Jongh, "Realism and Seeming Realism," p. 27 concedes, in relation to the landscape painting, that in this case it is possible that only "the form remains while the allegorical or moralizing contents evaporate”; cf. Goedde, Naturalism, pp. 129-43, 132.
} 
by Schoubroek — himself a religious refugee in Frankenthal - perhaps thereby simultaneously capture the fire and exile experience associated with the wars of religion, although this is not specified in the paintings. Each and every fire was implied in these paintings-whether caused by war or not. The emblematic surplus concerning the choice of fictional Biblical/mythological subjects reflected this general applicability and thereby drew the focus and feelings of the observer entirely toward the fire itself. ${ }^{22}$ This notion is also supported by the fact that in the case of Schoubroek, the paintings were painted on copper, probably so that they would shine in a small, dark chamber: the virtuosity of the material illustration and the effect of the fire's glow were also important. ${ }^{223}$ If Biblical and mythological images of fire in oil painting before $165^{\circ}$ stand in for depiction of real fires in painting, then this substitution can be interpreted as an element of the decorum of the first half of the early modern period already touched upon above: on the one hand, the representation of non-sacred and non-mythological subjects was, of course, effectively not allowed; on the other hand, representing actual cities as destroyed may have also contradicted the dignity of the cities as bearers of their own culture of identity and memory.

\subsubsection{Temporalization, Eventfulness and Affect Control}

There is one key difference that distinguishes landscape paintings from city fire paintings, which are otherwise classic objects of art history research concerning Dutch painting: in Dutch paintings, the landscape tends to be calm, motionless; still lifes are also influenced by this timeless, contemplative

222 In contrast to Alpers's theory (that the Dutch visual culture owes its character of proximity to the descriptive/empirical sciences and their instruments) Goedde emphasizes that the artistic landscape image is characterized by a "contrived informality and apparent spontaneity of realistic landscapes," and presupposes a "sophistication of purpose and taste on the part of both artists and buyers of art." Landscape painting functions precisely based on the paradox that it is an illusion of reality and the appearance of an unmediated, natural experience that could be accomplished only through the practice of the highest artistic abilities, not just the application of cartographic and measurement craftmanship transferred from administrative and technical purposes to art (Goedde, Naturalism, p. 142f.). Both approaches are not incompatible: artistic play combined with the enjoyment of the now realized instrumental culture of visuality that has become so familar is in fact derived from this, even as it presupposes it.

223 For the material specifications, see Krämer, Brand von Troja, p. 1olf. (e.g., note 53). In Karel van Mander's treatise, fires are treated in Ch. 7 ("Van de Reflecty, Reverberaty, teghenglans oft weerschijn"), with precise information how the artistic representation of sparks, firelight can be realized. 
mood. ${ }^{224}$ In Vermeer's paintings, it is often momentary movements that are recorded - a stream of water that has just been poured from a jug, a glass from which someone has just drunk, a letter that is just being read. ${ }^{225}$ But they always concern small movements in the framework of general peace. Images of ruins might be endowed with a certain reference, pregnant with meaning, to a disastrous event, from which they had been generated; however, as imageobjects they express a "temporal continuity." 226 While city fire painting can be classified, also chorographically, as a subgenre of the landscape tradition, it is the momentary quality, the emotion of the catastrophic moment that stands at the center in these paintings. Chorography does not appear to exclude a temporalization of "landscape" and the specific affect control associated with it: ${ }^{227}$ the landscape becomes not only the main autarchic subject, but also a threatening actor generating affect control and a point of reference for its impact.

This trend, noticeable in the Dutch Troy and Sodom paintings, appears less often in contemporaneous oil paintings of actual city fires than in corresponding engravings. News broadsheets reporting on sieges and other war events often depicted fires "in action," as did the less common depictions of city fires not related to war- the Passau fire of 1662 and the Annaberg fire of 1664 are easily accessible examples in this regard. ${ }^{228}$ In addition there was a wide variety of independent broadsheets.

224 "Nothing ever happens" (Alpers, Art of Describing, p. 147 with regard to Dutch landscape painting). On the content, for example, of van de Velde's landscape engravings, cf. Levesque, Journey, p. 105: "throughout the seasonal and peasant prints, man-simple and natural, and specifically Dutch—is shown in harmony with his environment, and with time, cosmic and agricultural."

225 Cf. Markus A. Castor, "Augenblick und Zeitfluß—Bemerkungen zu einigen Konstanten in der Malerei Jan Vermeers," Pantheon 54 (1996), pp. 84-101.

226 "They commemorate past troubles, celebrate present-day abundance, and encourage future vigilance." (Levesque, Journey, 59).

227 In order to avoid misunderstandings, it should be pointed out that the concept of temporalization has already been addressed in the context of landscape painting by Josiane Rieu in her article "La temporalisation de l'espace" in Le Paysage à la Renaissance, ed. Yves Giraud (Fribourg: 1988), 297-310—albeit in a much different sense. She discusses the reintroduction of a neomedieval pluritemporality from temporally distant action- and biographical elements in the landscape sphere of the mannerism school of Fontainebleau from around 1540, after the common representations from the Middle Ages (e.g., of saints in a tableau) had been repressed during the Italian Renaissance.

228 Both representations are easily accessible through the databank "Prometheus" and the broadsheet digitalization of the state library of Bavaria: http://www.bsb-muenchen.de/ Einblattdrucke.178.o.html. Cf. Horst Carl, “'Brüssel 1695': Kriegszerstörungen und ihre Visualisierung im späten 17. und 18. Jahrhundert," in Birgit Emich and Gabriela Signori (eds.), Kriegs/Bilder in Mittelalter und Früher Neuzeit, Berlin 2009, pp. 295-315. 


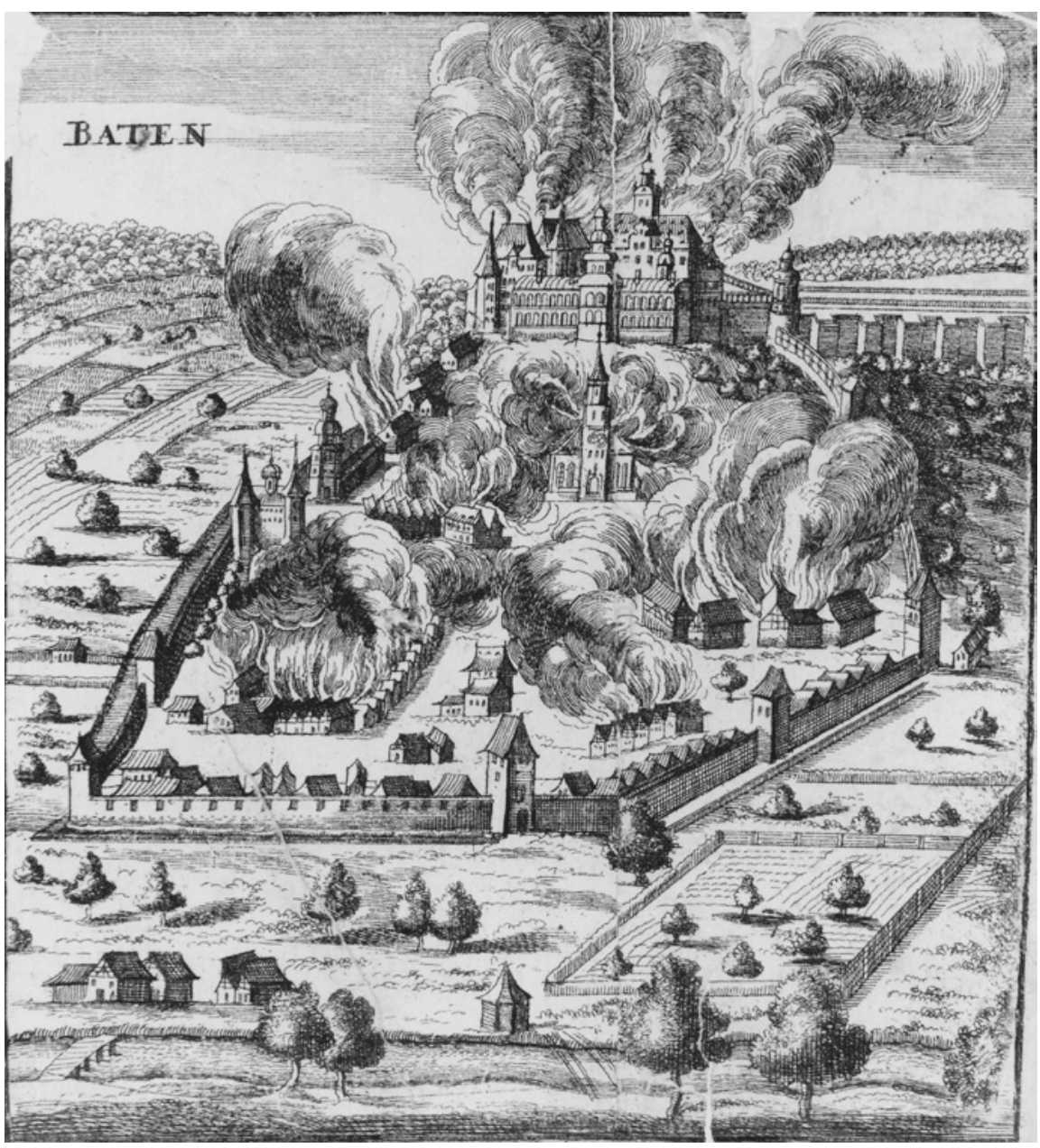

FIGURE 32 Engraving of Baden-Baden burning during the Palatinate war of 1689, as in Wahrmund, Die Jammer-gedrückte [...] Neckar-Pfalz (cf. n. 229), Stadtmuseum und -archiv Baden-Baden, Inv. Nr. 317

For example, images of the fires of Baden-Baden in 1689 (Fig. 32) 229 , Esslingen in 1701 (Fig. 33) ${ }^{230}$, and Goslar 1728 (Fig. 38) featured remarkably vivid

229 Theophil Wahrmund [pseud.], Die Jammer-gedrückte, Hülffleistend erquickte, Und Kronenbeglückte Rhein- und Neckar-Pfalz [...] Wie solche, samt andern benachbarten Ländern und angränzenden Flüssen, [...] von denen alles-verheerenden Franzosen, so übelzugerichtet, und jämmerlich verwiestet worden, s.l. 1691, between p. 238 and 239. I thank Heike Kronenwett of the Stadtarchiv/Stadtmuseum Baden-Baden for providing me with a copy.

230 Entsetzliche Feuers=Brunst/ Welche den 25. Octobr. des zuruckgelegten 1701. Jahrs/ die Reichs-Stadt Eßlingen troffen/ und leider! solche mehrertheils eingeäschert (from Stadtarchiv Esslingen — with gratitude to Ursula Kümmel). 


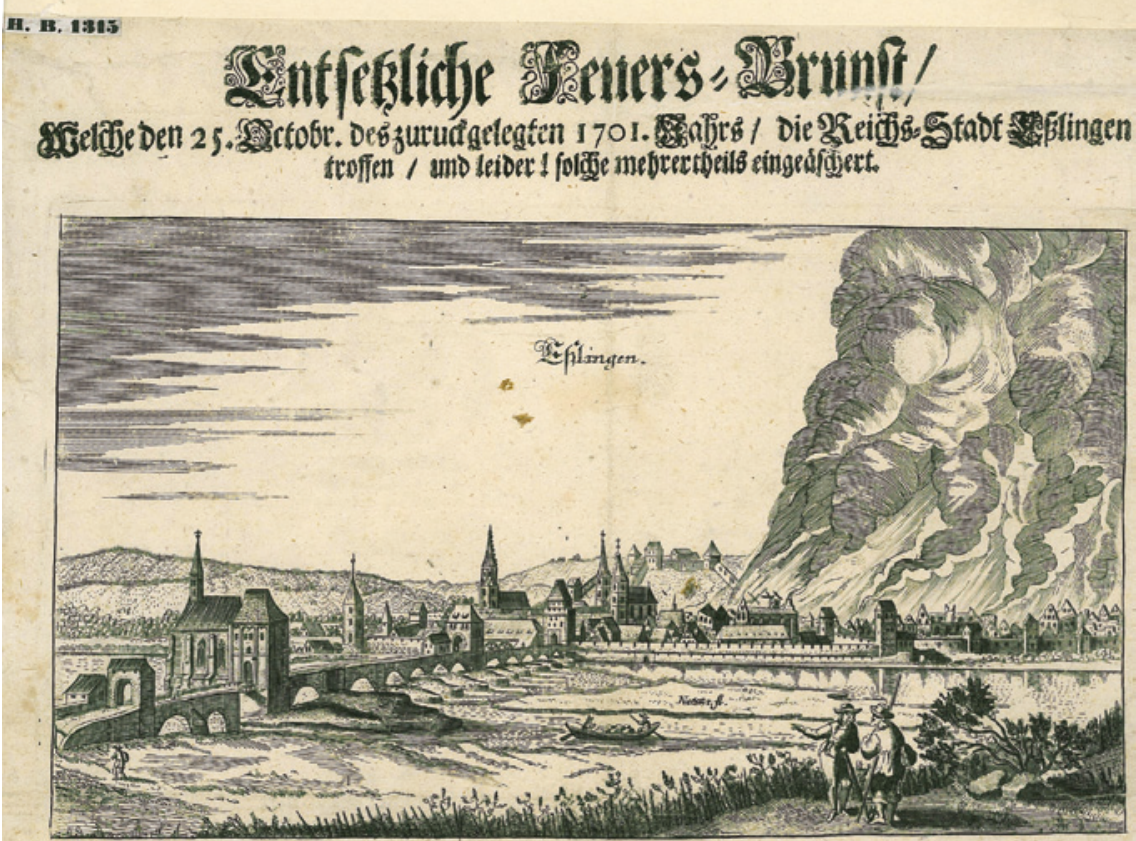

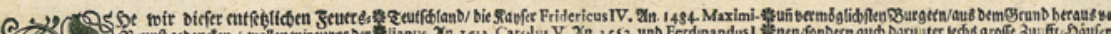

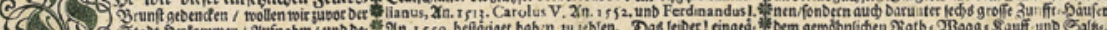

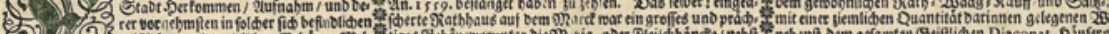

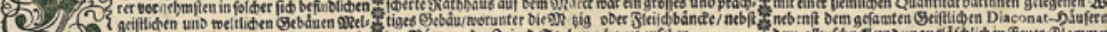

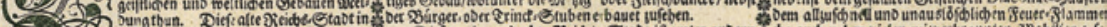

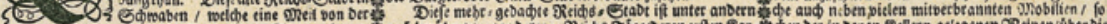

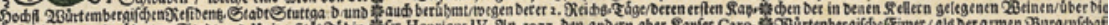

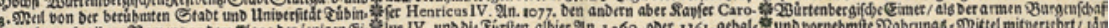

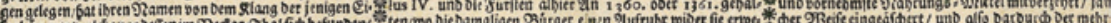

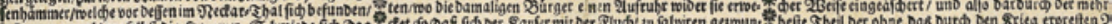

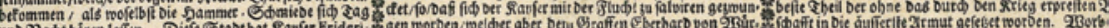

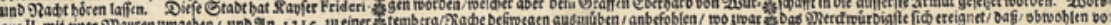
cus II. mit enter whau ner

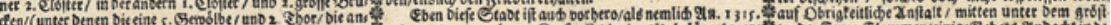

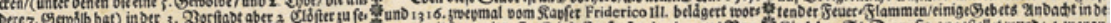

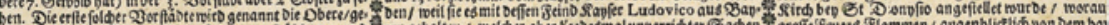

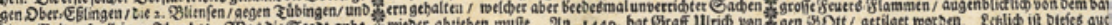

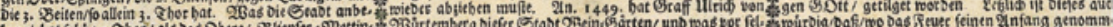

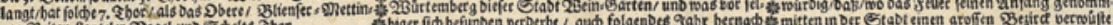

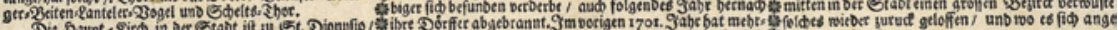

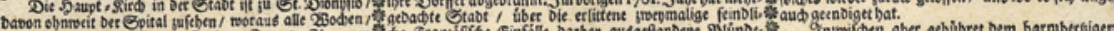
Dabon obrnteit Der Spital jufecten / morazs alle 23aden/

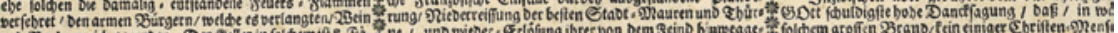

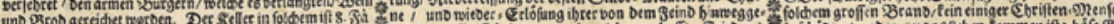

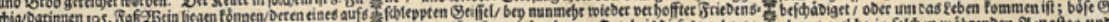

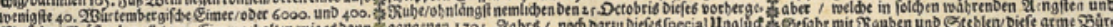

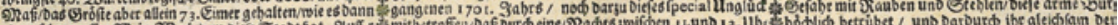

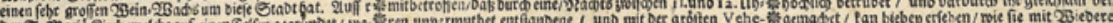

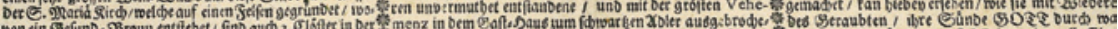

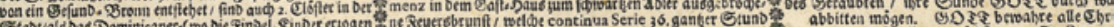

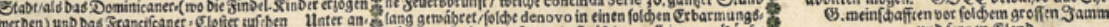

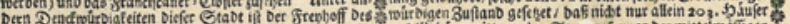

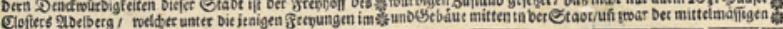
und fernen Elend.

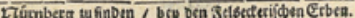

FIGURE 33 Engraving on single-leaf broadsheet of the Esslingen fire, October 25, 1701, Stadtarchiv Esslingen Karten und Pläne Q 15, printed in Nürnberg, Felseckerische Erben 


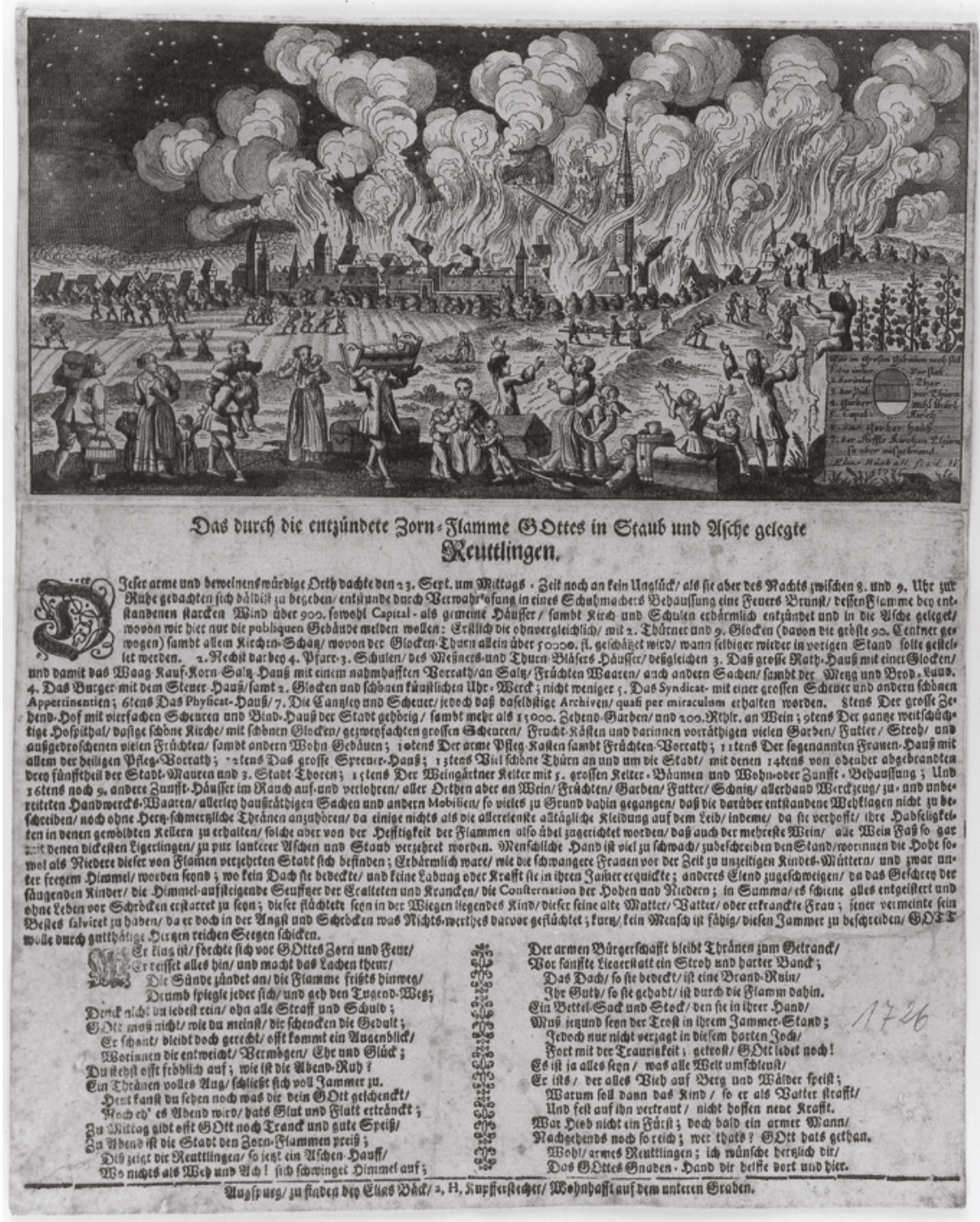

FIGURE 34 Engraving on single-leaf broadsheet of the Reutlingen fire September 23, 1726,

Historisches Museum Reutlingen, Nr. 12, printed Augsburg: Elias Bäck

representations of fire, as did images of the Reutlingen fire of 1726 (Fig. 34 to $37,39)^{231}$ — clearly one of the most frequently illustrated fires.

231 Cf. Werner Ströbele, "Der Stadtbrand von 1726 — ein Ereignis schafft Bilder," in StadtBild-Geschichte. Reutlingen in Ansichten aus fünfJahrhunderten. Katalog und Ausstellung, Reutlingen 1990, pp. 49-56. On the fire see P. Schwarz, "Der große Reutlinger Stadtbrand im September 1726," in Reutlinger Geschichtsblätter 14 (1976), pp. 7-43. 


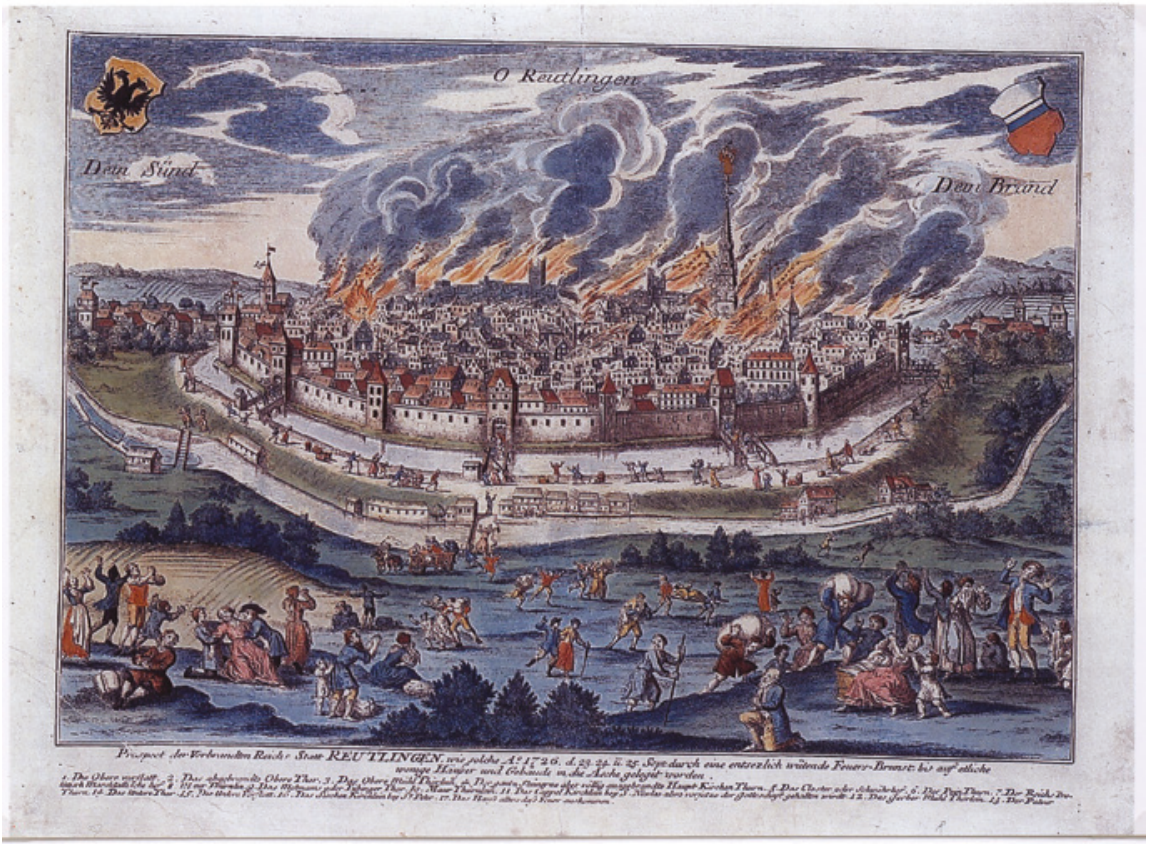

FIGURE 35 Hand colored engraving of the Reutlingen fire of 1726, Historisches Museum Reutlingen, Nr. 994

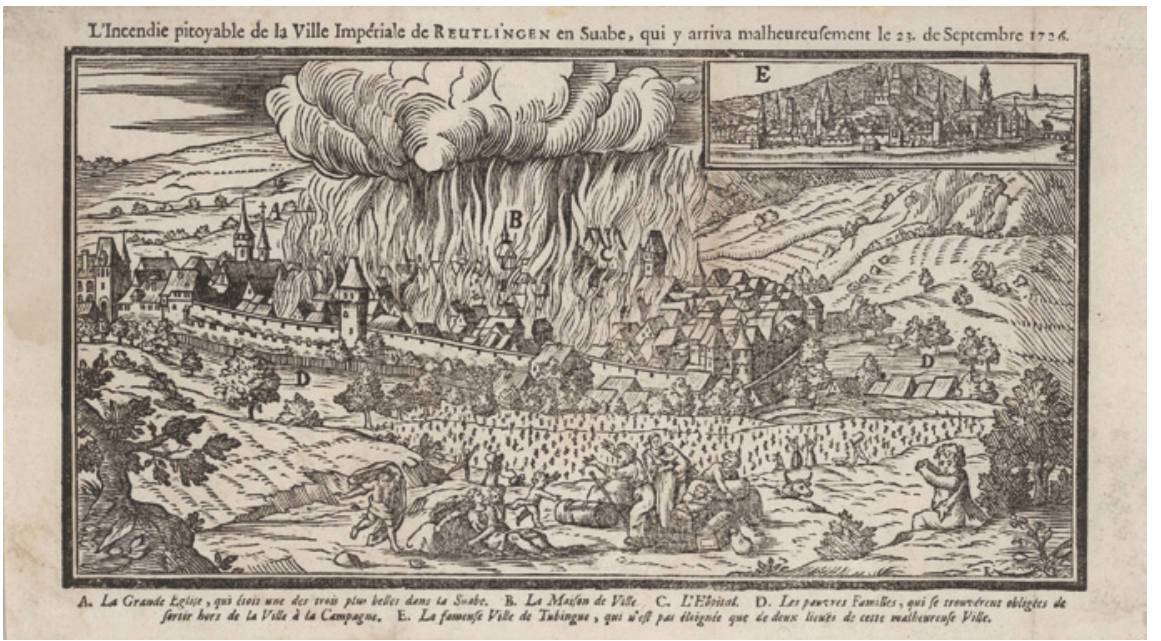

FIGURE 36 French Single-leaf woodcut of the Reutlingen Fire of 1726, Städtisches Museum Ludwigsburg Nr. 1131 


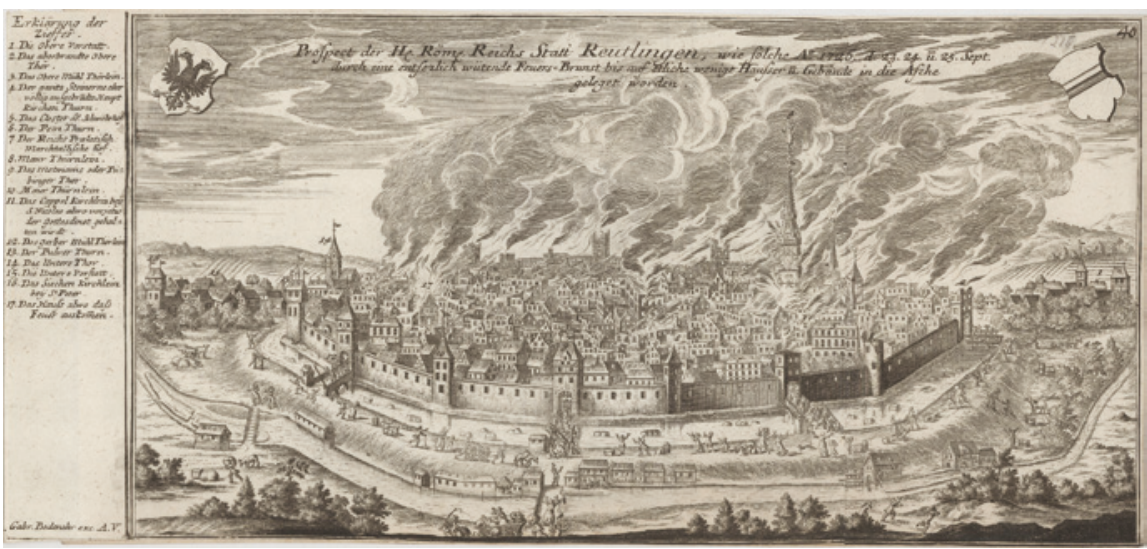

FIG URE 37 Engraving of the Reutlingen fire of 1726 by Gabriel Bodenehr, Prospect der Hl. Röm. Reichs Statt Reutlingen, wie solche A. ${ }^{\circ} 1726$, d. 23. 24. u. 25. Sept. durch eine entsezlich wütende Feuers-Brunst bis auf etliche wenige Häusser u. Gebäude in die Asche geleget worden, Städtisches Museum Ludwigsburg Nr. 1132

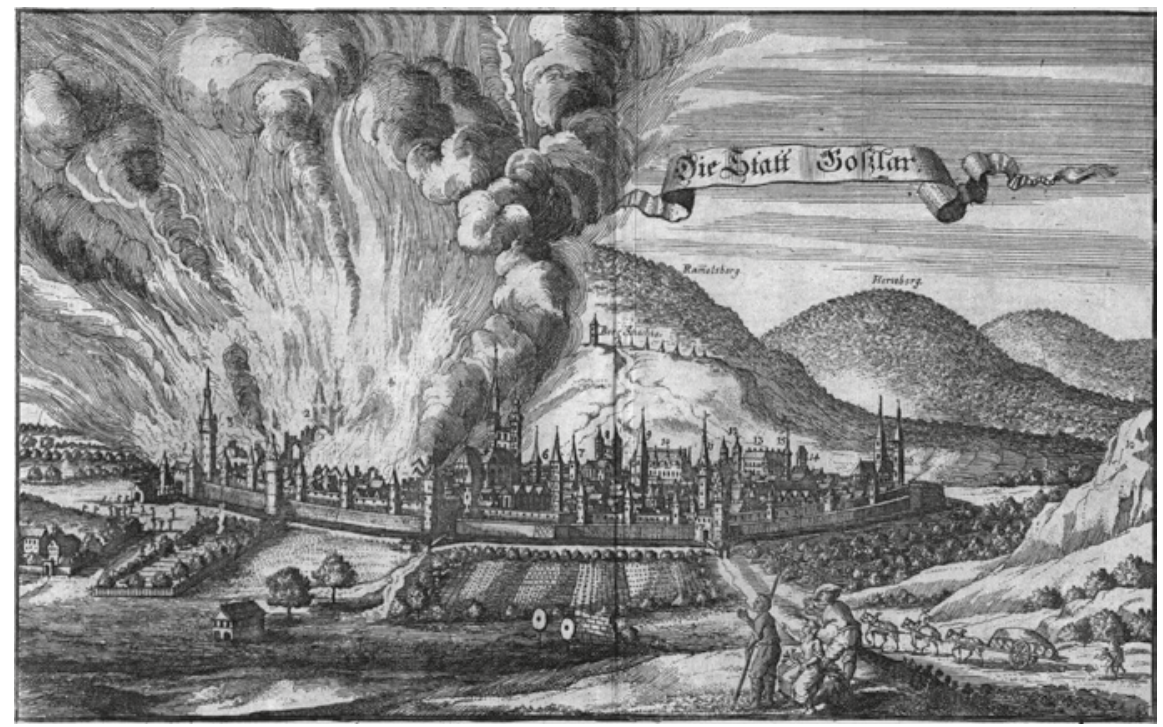

FIGURE 38 Engraving of the Goslar city fire of 1728 as published in the Verbesserter und Neuer Kriegs-Mord-und Tod-Jammer- und Noth-Calender (Nürnberg 1729), Stadtarchiv Goslar 


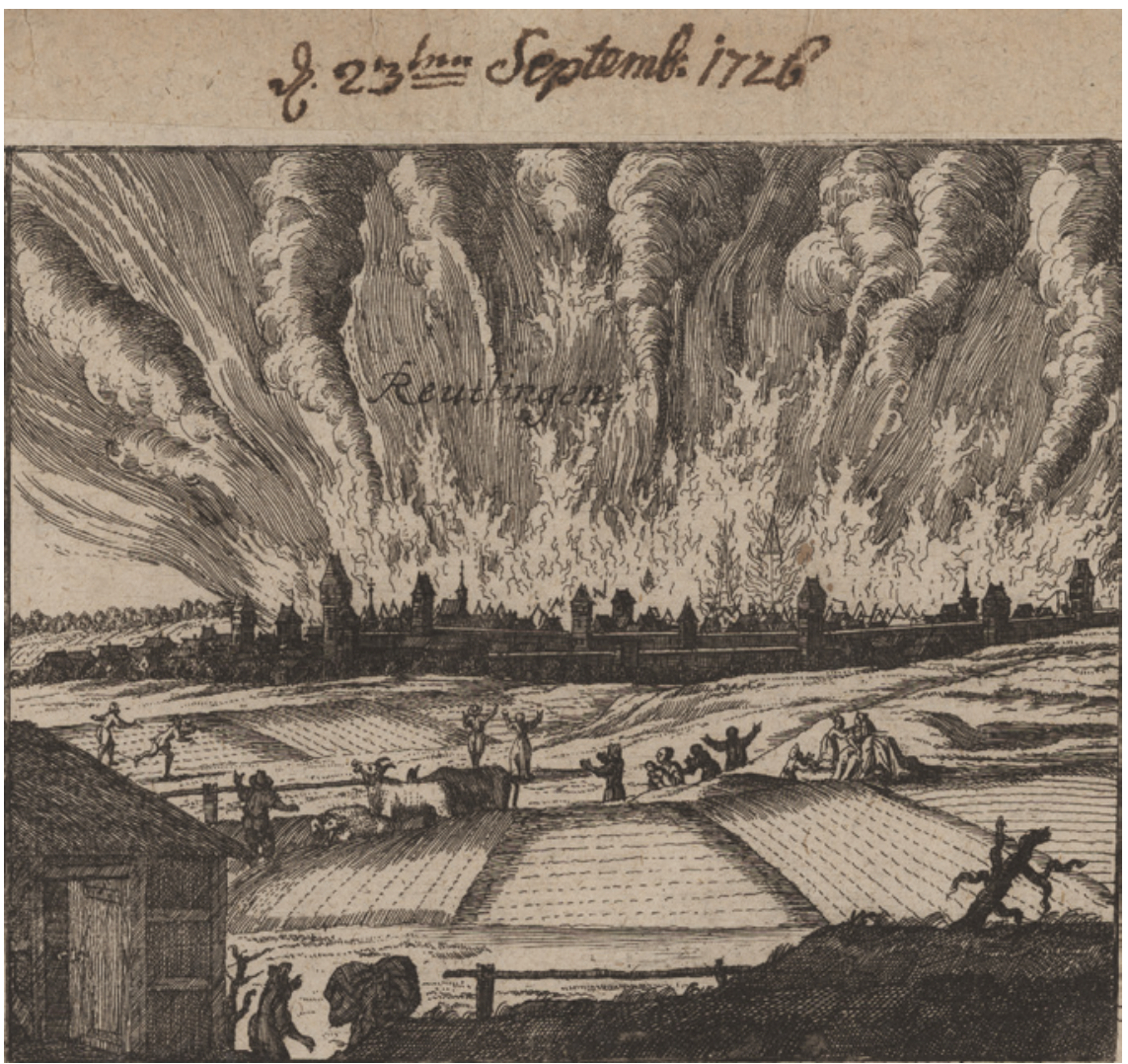

FIGURE 39 Small anonymous engraving of the Reutlingen fire of 1726, Städtisches Museum Ludwigsburg Nr. 1145 (Schefold 6462)

One engraving in particular (Figure 39) should be emphasized here, in which the forms of people, full of suffering and reaching toward heaven with outstretched hands, are mirrored in the tongues of flame reaching upward into the heavy curtain of smoke. The group of horrified people reinforces the line of the town wall: the contours of the elemental violence and the contours of the expressions of suffering, fear, and horror are isomorphic. This is a different, new imagery, which combines representations of disaster with the suffering of mankind. The meadow and barn in the foreground are not primarily depicted as spaces of safety in contrast to the inferno of the city; rather, the disaster situation neatly comprises the image as a whole.

At about the same time, the French engraving of the biggest early modern city fire in France (Rennes, 1720) appeared, capturing the situation, the moment, and the perspective of the dramatic inferno in very different ways and 


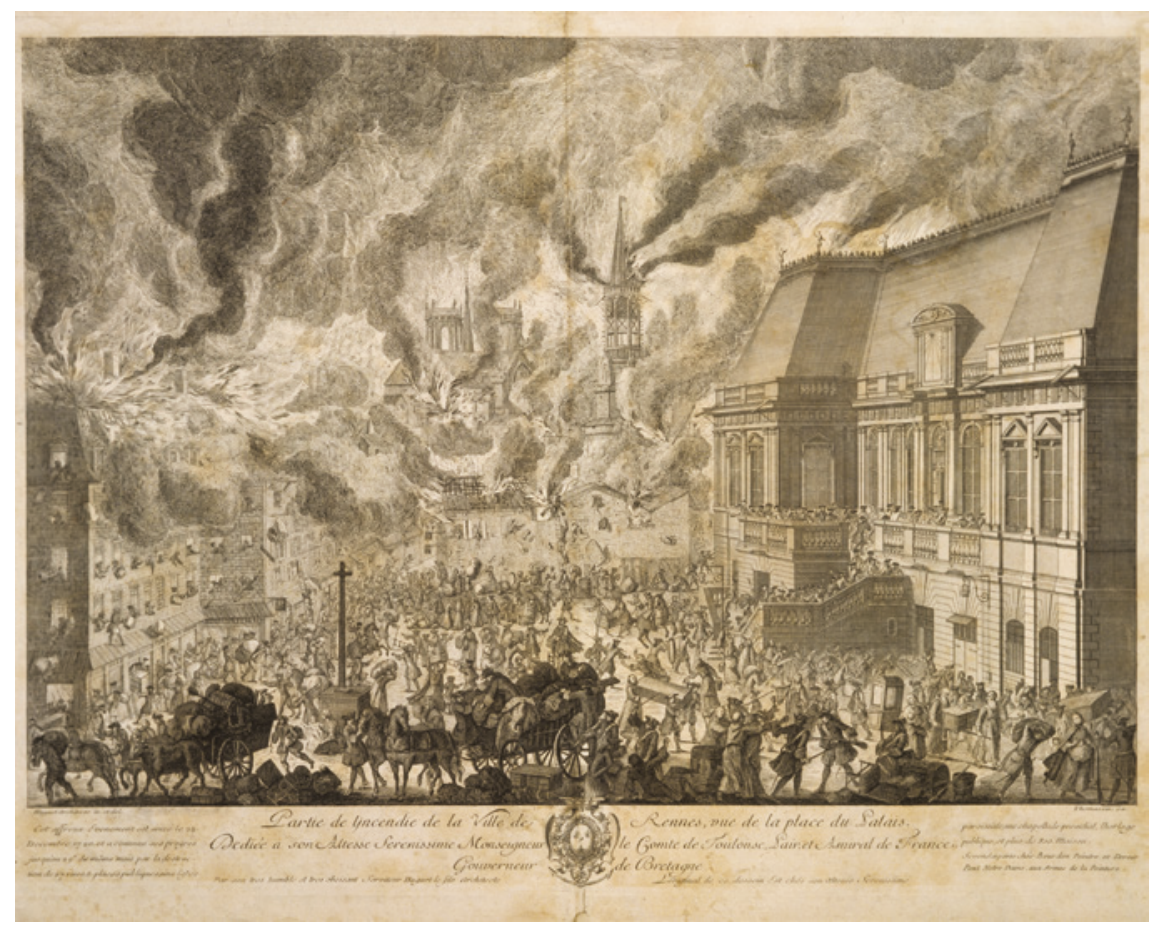

FIGURE 40 Engraving by Thomassin after a drawing by Jean-François Hughes of the Rennes city fire December 22 to 29, 1720, Musée de Bretagne, Inv. Nr. 86.2684.E.2

means than the listless aerial-view oil paintings of the seventeenth century (Figure 40). The view of the crashing avalanche of flames is from the town square itself and the observer of the engraving feels just as suffocated by the clouds of smoke and just as oppressed by the wall of flames as the residents depicted fleeing the fire. We can see the details of people throwing down their possessions at the last moment and clearly discern beams and roofs in the midst of the fiery explosion. This is unquestionably a much more strongly affect-oriented representation than seen in most surviving oil paintings-it comes closer in effect to a Troy or Sodom painting.

There also seems to be a developmental step between the aesthetics of the single-leaf news broadsheets and representations such as this one, which is most famously associated with Jan van der Heyden. His Brandspuitenboek (Fire Hose book) always presents the scene of the fire itself and above all the attempts at fighting the fire from the perspective of someone directly involved (Figures 41, 42) - Susan Donahue Kuretsky has aptly described this as taking the perspective of the fireman, a particularly appropriate description 


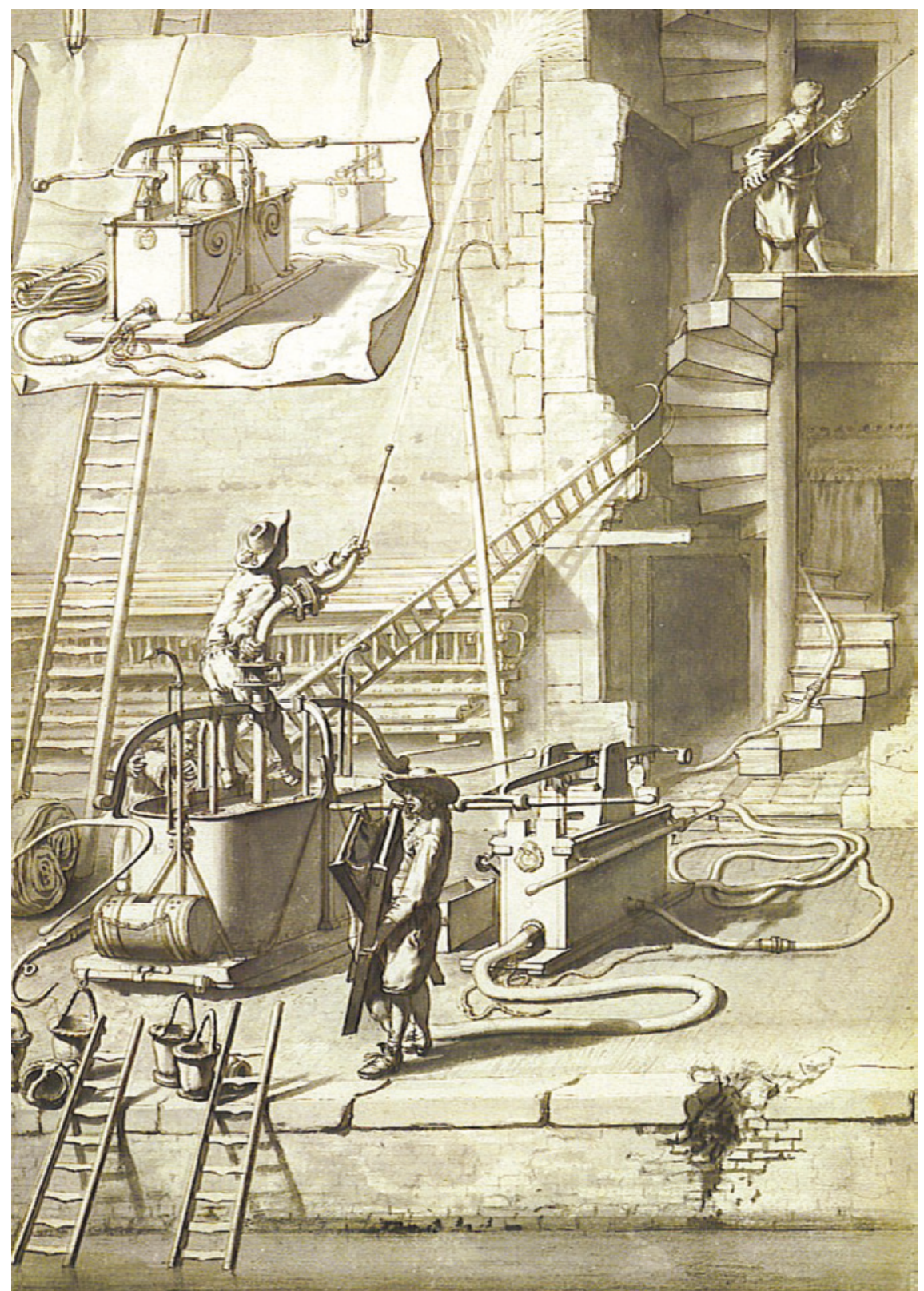

FIGU RE 41 Jan van der Heyden, Fire men using fire equipment, pen and wash drawing, plate 1 of the 169 o Beschrijving 


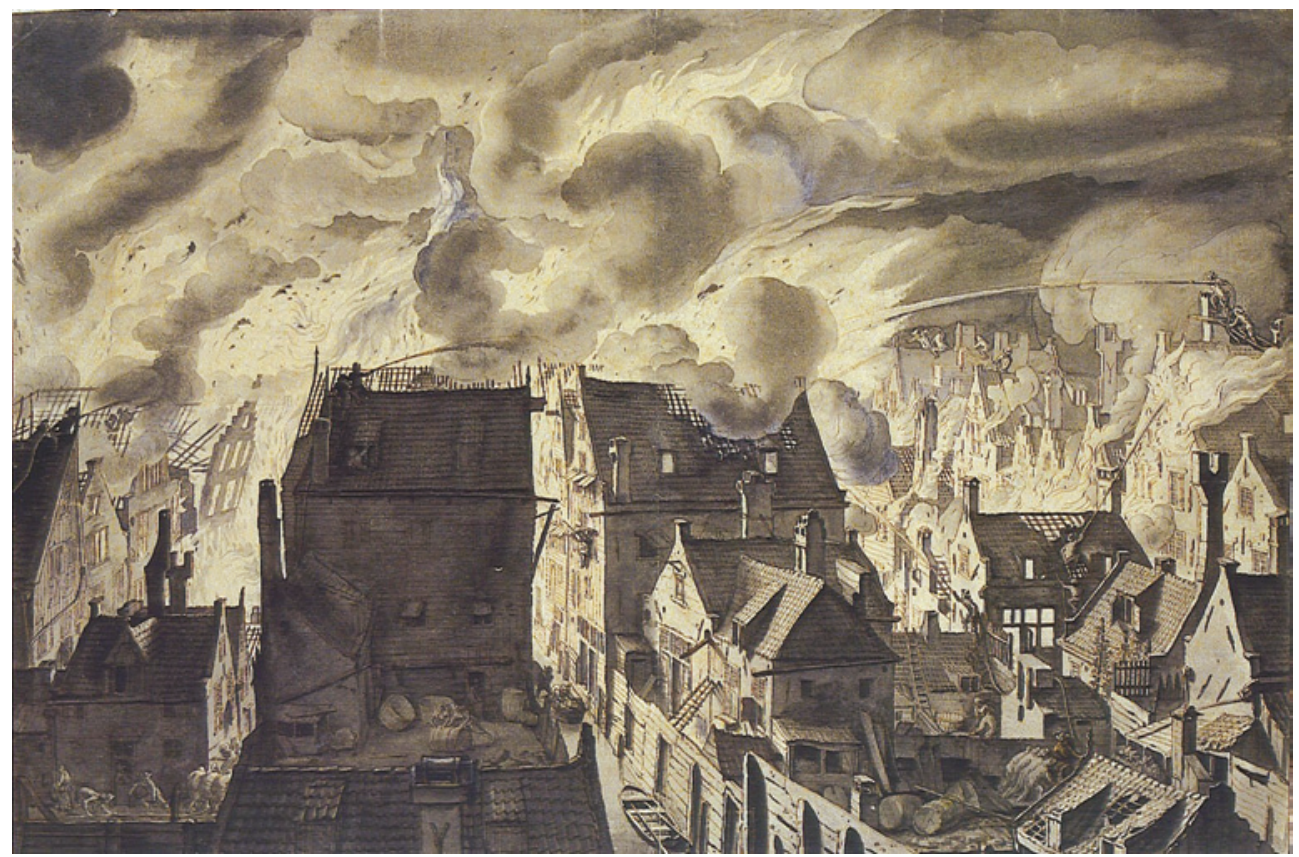

FIG URE 42 Jan van der Heyden, Firemen fighting a fire after a lightning struck four rows of adjoining houses between Elands Canal and Elands Street in Amsterdam, July 27, 1679, plate 8 of the 1690 Beschrijving

in this context as Jan van der Heyden was indeed chief of the Amsterdam fire department. ${ }^{232}$

As realistic and gripping as his fire representations are, they are also influenced by his particular perspective and also by the specific context of their publication: Van der Heyden intended to use these images as advertisements

232 The original title is Jan van der Heyden, Beschrijving der nieuwlijks uitgevonden en geoctrojeerde Slang-Brand-Spuiten [..], Amsterdam 169o. Cf. Jan van der Heyden, Fire Engines with Water Hoses and the Method of Fighting Fires now used in Amsterdam, Canton 1996; Hans Wildeboer, "De ontwikkeling van de brandspuit in de zeventiende en achttiende eeuw," in Jaarboek voor de Geschiedenis van Bedrijf en Techniek 10 (1993), pp. 9-41, 23-35; Peter C. Sutton (ed.), Jan van der Heyden (1637-1712), New Haven 2006, pp. 73-81; Susan Donahue Kuretsky, "Jan van der Heyden and the Origins of Modern Firefighting. Art and Technology in Seventeenth-Century Amsterdam," in Bankoff, Lübken and Sand (eds.), Flammable Cities, pp. 23-43, 35 . 
for his invention of the fire hose (1671-1676), which he first distributed throughout Europe on a large scale. Especially in western German municipal archives near the Netherlands, such as Aachen and Cologne, the engravings, which Van der Heyden distributed as advertising brochures with instructions for using his fire hoses, can still be found today (see below Ch. 3, 3.1-2). As eighteen fire hoses are shown in use in the depiction of the burning of one Amsterdam canal house (plate 2 of his Fire hose book), this can hardly be considered a "realistic" example-outside of Amsterdam, hardly any European city possessed that many large fire hoses around 1700 and they were of course never simultaneously employed to fight a single house fire. In this case, the goal was obviously the presentation of the formidable operational capability and manoeuvrability of the hoses and what might be called an "super-realistic" representation.

Whether the engravings and similar drawings prepared for the Brandspuitenboek were sent also, in a similar fashion as the fire hose advertisement engravings and broadsheets themselves, to city magistrates and princes, and whether the innovative and dramatic style of the images, geared toward producing affects of fear, worry, and anxiety about possible future fires in one's home town, should therefore be put into the context of this purpose of advertising of the product, is not clear from current archival documentation. ${ }^{233}$ In any case, in examining the remaining Van der Heyden ouvre, it can be determined that there is not a single fire image among his color oil paintings - neither a Biblical or mythological image nor one related to a real fire, though he is known

233 Recent research just on this question of how advertisement for fire hoses was done in small Lower Rhine and Westfalian cities has not revealed any further information on this particular question concerning van der Heyden's sketches and engravings, Christine Brauner, "Recommendation und Reklame. Niederrheinische Brandspritzenmacher und Praktiken der Werbung in der Frühen Neuzeit," Zeitschrift für Historische Forschung 46, 1 (2019), pp. 1-45. For the (mostly eighteenth century) history of advertising in the Anglo-American context cf. Christine Y. Ferdinand, "Selling it to the Provinces: News and commerce Round Eighteenth-Century Salisbury", in John Brewer and Roy Porter (eds.), Consumption and the World of Goods, London 1993, pp. 393-411; Timothy H. Breen, The Marketplace of Revolution: How Consumer Politics Shaped American Independence, New York 2004; Emma Hart, "A British Atlantic World of Advertising? Colonial American 'For Sale' Notices in Comparative Context, American Periodicals 24, 2 (2014), pp. 120-127; Jon Stobart, Sugar \& Spice. Grocers and Groceries in Provincial England, 1650-1830, Oxford 2016, chapter 7 ('advertising'). However, this is embedded into the framework of a history of (individual, private) consumption like the history of the Bureaux d'adresse, while the diffusion of technological innovation in a semi-public network of governmental and intermagistrate communication is still different on what concerns the distinction between the private and public realm. 
as one of the most important city landscape painters of his time. ${ }^{234}$ In fact, there are hardly any surviving Troy or Sodom paintings in the style of Breughel, Mostaert, Schoubroek, or Keuninck from the second half of the seventeenth century on. This genre seems to have gone extinct in the oil painting sector. With Van der Heyden and Ruisdael, the city itself as a landscape object is discovered, ${ }^{235}$ but even more so, there seems to be a functional differentiation at work: while landscape oil painting is devoted to more contemplative, quiet observation, engraving and drawing captures moments and dynamic situations of movement. ${ }^{236}$

The aesthetics of the dynamic image are first realized only in images that capture discrete moments. The almost comic-like aesthetics known today, of the movement of firebombs marking flight lines, originates in the news medium of the news broadsheet or "flyer."237 Even the constant linking of representation and commentary in the form of the legend that not only memorialized the names of people and places, but also situational moments in the image, fixed a specific moment of time in the representation. This informative, temporalized aesthetic of event reporting was broadcast so far into the realm of painting that legends were embedded into almost all known oil paintings of contemporary fires. ${ }^{238}$

The next step was perfecting the representation of the disaster as a temporal moment itself, in particular regarding explosions. This is comparable to the high-speed footage of Harold Edgerton, in particular his now-iconic and almost universally recognized image from 1939, in which a water droplet hits the water-a phenomenon that is invisible to the naked eye. ${ }^{239}$ In the same

234 Helga Heikamp-Wagner, Jan van der Heyden, Amsterdam 1972; Sutton, Jan van der Heyden.

235 On this concept see Jan Peeters, "De stad als landschap de stad als stilleven," in Kunstschrift/ Openbaar Kunstbezit 36 (1992), pp. 20-24.

236 Cf. Arthur K. Wheelock, "Accidents and Disasters," in Susan Donahue Kuretsky (ed.), Time and Transformation in Seventeenth-Century Dutch Art, New York 2005, pp. 73-82.

237 Cf. Wolfgang Harms (ed.), Deutsche illustrierte Flugblätter des 16. und 17. Jahrhunderts, 7 vols., Stuttgart 1980-2005, vol. 2, Nr. 163; on the 1610 siege of Jülich, vol. 2, Nr. 402; on the 1631 conquest of Magdeburg, vol. 2, Nr. 546; on the 1641 siege of Hohentwiel, vol. 2, Nr. 613; on the siege of Neuhäusl, vol. 2, Nr. 664; on the 1664 siege of Kanischas; vol. 4, Nr. 369, on the 1675 conquest of Trier.

238 That relates somewhat to the above-mentioned fire images of Aachen 1656, Göppingen 1782 , and Goslar 1728 .

239 See Gunnar Schmidt, "Splashes \& Flashes. Über High-Speed-Visualisierungen und Wissensformen," in Inge Hinterwaldner and Markus Buschhaus (eds.), The Picture's Image. Wissenschaftliche Visualisierung als Komposit, Munich 2006, pp. 180-95. 
way, an engraving, such as that of 175 , showing the explosion of the burning St. Michael's Church Tower in Hamburg, fixes visually a moment that could never have actually been seen to that degree of detail, and could not have been remembered as such. It is this temporalized aesthetic that constructs the visual event - that stupendous, threatening moment-in order to render the event as a whole (the fire of the Hamburg Church), capable of being experienced in a visually sublime form (Figure 43).

Through the technical possibilities of exposing the actual moment, photography capitalizes on the possibility of creating simultaneity between the event and image production; ${ }^{240}$ however, the fascination with the event-ness itself and the search for its adequate representability and the specific possibilities of affect control associated with that are much older, as this eighteenth century image proves. ${ }^{241}$ In graphics and in single-leaf engravings and woodcuts this temporalization of disaster representation was increasingly perfected.

Even after the fire, these media served not only the purposes of remembrance, like oil paintings, but were also part of post-fire communications, in which the temporalized images that focused on the natural catastrophe as an actual affect-controlling subject contributed to a specific function of appeal intended to trigger various acts of solidarity — not least of which were donations. $^{242}$

\subsubsection{Threat Perception, Security Requirements, and Emotionalization}

Embedded within representations of city fires is thus an appellative and affective script that can be interpreted according to their relationship with and,

240 The invention of the snapshot takes place around 1880, as the collodion method was replaced by a high-resolution, momentary exposure process (improvement of the bromine silver-gelatin method) and thus made on-site photographs captured with a portable camera possible. Cf. Bibliothèque nationale de France (ed.), La Révolution de la photographie instantanée 1880-1990, Paris 1996; André Gunthert, "Esthétique de l'occasion. La naissance de la photographie instantanée comme genre," Études Photographiques 9 (2001), pp. $64-87$.

241 Van der Heyden's images were compared with photography as early as the nineteenth century—see Alpers, Art of Describing, p. 29.

242 Like the St. Michael's church tower explosion image and the fire sermons in the context of the massive donation efforts (see above p. 116 and n. 145), similar collection contexts could often be inferred from the texts on the broadsheets. Most broadsheets today have, however, been separated from their original contexts and included in collections of images or engravings, while collection books and donation notations, if they are preserved at all, are preserved again at different places, to be found in parish documents and state records of collections, charity briefs, donations, etc. Historically, however, both are important parts of a one single function and activity, even though the images that were later detached also serve as a remembrance. 


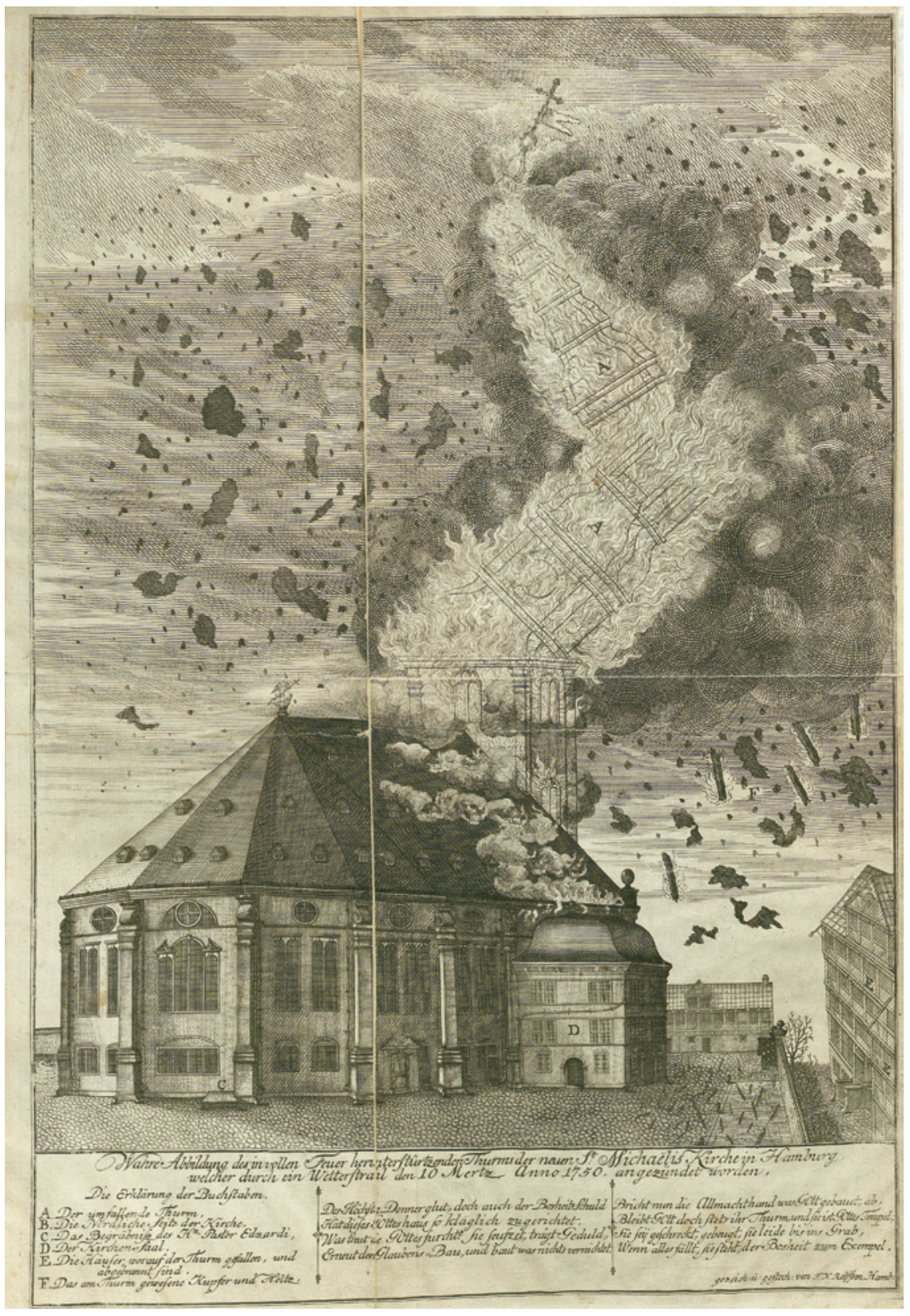

FIGURE 43 Explosion of St Michael's church tower after lightning strike in 1750. Anonymous engraving in the miscellaneous volume on the 175 o event, HStA Hamburg, Bibliothek, A 640/77 
perhaps, causal contribution to change and the bridging of an epochal threshold of security history in the longue durée. ${ }^{243}$

Art theorists of the Renaissance and the seventeenth century were already engaged in complicated reflections concerning affect control through art and in relation to the conceptualization of the role and perspective of the observer via the painter, primarily in recourse to the theory of affect, which first originated in rhetoric. This link to rhetoric, however, meant that these theories were functionally primarily tied to figural representations. Observers are conceptualized as audience members listening to a speech, who are emotionally engaged by the expressive capacities of the represented persons. For example, the sixth chapter of Karel van Manders' Schilder-boeck on the representation of affect ("Wtbeeldinghe der Affecten, passien, begeerlijckheden, en lijdens der Menschen") specifically concerns representations of people, whose suffering or joy has the capacity to invoke corresponding empathy in observers; in contrast, the chapter on landscape (Ch. 8) primarily emphasizes practical instructions on how to paint things effectively, with no mention of associated emotions. ${ }^{244}$

In any case, a general tendency for visualizations of city fires was that people increasingly disappeared and that the fire itself became the main subject. In the overall schematics of Troy and Sodom in paintings around 160o, the minor figures of fleeing people, of Aeneas and Lot in the mostly dark foregrounds, appear so superfluous that they seem hardly capable of operating as a focal point for generating an emotional response; even if they were, they are only schematically perceivable as a group. This dynamic was, of course, different in the Italian tradition, and it was with good reason that affect in Raphael's Incendio del Borgo was linked to the then new reception of the Aristotelian theory of tragedy. ${ }^{245}$ However, in Dutch and Portuguese painting, as well as in the

243 For further theoretical discussions see William M. Reddy, "Against Constructionism. The Historical Ethnography of Emotions," in Current Anthropology 38, no. 3 (1997), pp. 32751; William M. Reddy, "The Logic of Action. Indeterminacy, Emotion, and Historical Narrative," in History and Theory 40 (2001), pp. 10-33; Katja Mellmann, Emotionalisierung. Von der Nebenstundenpoesie zum Buch als Freund. Eine emotionspsychologische Analyse der Literatur der Aufklärungsepoche, Paderborn 2006; J. Plamper, "The History of Emotions: An Interview with William Reddy, Barbara Rosenwein, and Peter Stearns", History and Theory 49 (2010), pp. 237-65.

244 On the reconstruction of Dutch art theory see the relevant work: Andreas Hahn, "... dat zy de aanschouwers schynen te willen aansprecken"-Untersuchungen zur Rolle des Betrachters in der Niederländischen Malerei des 17. Jahrhunderts, Munich 1996.

245 J. Rasmus-Brandt, Pity and Fear. “A note of Raphael's 'Incendio del Borgo,'” Acta ad Archaeologiam et Artium Historiam Pertinentia. Institutum Romanum Norvegiae Roma N.S. 1 (1981), pp. 259-74. 
"temporalized" fire representations in engravings and woodcut broadsheets, the observer directly faces the fire. This perspective and the possibilities for identification are based on the small and powerless-seeming individuals in contrast to the forces of nature. In fire representations in higher art (i.e., beyond votive pictures and pure local memorializations), the emergence and function of the aesthetic category of the sublime in the eighteenth century in conjunction with the classification of "natural disasters" as particularly terrible manifestations of the sublime is significant: ${ }^{246}$ the English aesthetic theories of the sublime that emerged in the late seventeenth century and culminated with Edmund Burke (1757), and later those of Schiller and Kant, mark the development of a theory exploited by the history of art, which was particularly significant for the absolutization of "terrifying nature," and which developed in tandem with the history of natural sciences in the eighteenth and nineteenth centuries. ${ }^{247}$

When, in the eighteenth century, volcano representations, especially Vesuvius images, like those of Jakob Philipp Hackert and Pierre-Jacques Volaire, became a popular genre, it was because they particularly clearly manifested this notion of terrifying nature. ${ }^{248}$ Most were fashioned using elemental symbolism - sea and moonlight against volcano fire-which formed the

246 For the parallel development in German literature, see Carsten Zelle, "Angenehmes Grauen." Literaturhistorische Beiträge zur Ästhetik des Schrecklichen im Achtzehnten Jahrhundert, Hamburg 1987.

247 Cf. Werner Busch, "Die Naturwissenschaften als Basis des Erhabenen in der Kunst des 18. und frühen 19. Jahrhunderts" in Jahrbuch des Historischen Kollegs (2004), pp. 83-110. For the early reception of Pseudo-Longinus peri hypseous see Hana Gründler, "'La più orrenda pittura'-Zu einer Ästhetik des Erhabenen in Vasaris Vite, in Koppenleitner, Rößler, and Timmann (eds.), Urbs incensa, pp. 61-79.

248 Sean Cocco, Watching Vesuvius: A History of Science and Culture in Early Modern Italy, Chicago 2012 counter-intuitively treats not this image tradition, but rather the visualscientific development of Vesuvius in the seventheenth century and, along with Hamilton (pp. 209-25), barely touches on the post-Hackert/Volaire era. Current discussions of the relationship between arts, literature and vulcanism have concentrated more on the perception of the bad weather situation after the Tambora eruption ('the year without a summer', 1816) Gillen d'Arcy Wood, Tambora. The eruption that changed the World, Princeton 2015, pp. 1-33; Adriana Craciun, "Writing the Disaster: Franklin and Frankenstein", Nineteenth-Century Literature 65, 4 (2011), pp. 433-480; Siobhan Carroll, "Crusades Against Frost: Frankenstein, Polar Ice, and Climate Change in 1818", European Romantic Review 24, 2 (2013), pp. 211-230-here, the relationship between the diegetic level of the narrative, the production process and the perception of a real weather anomaly caused by the eruption forms a less coherent line of causal or conditional argument, cf. Zwierlein, "Klimageschichte und Kulturgeschichte". For the development of the aesthetics of the sublime and the iconography of volcanic eruptions, this is a logic internal to the artistic episteme, therefore less problematic. 


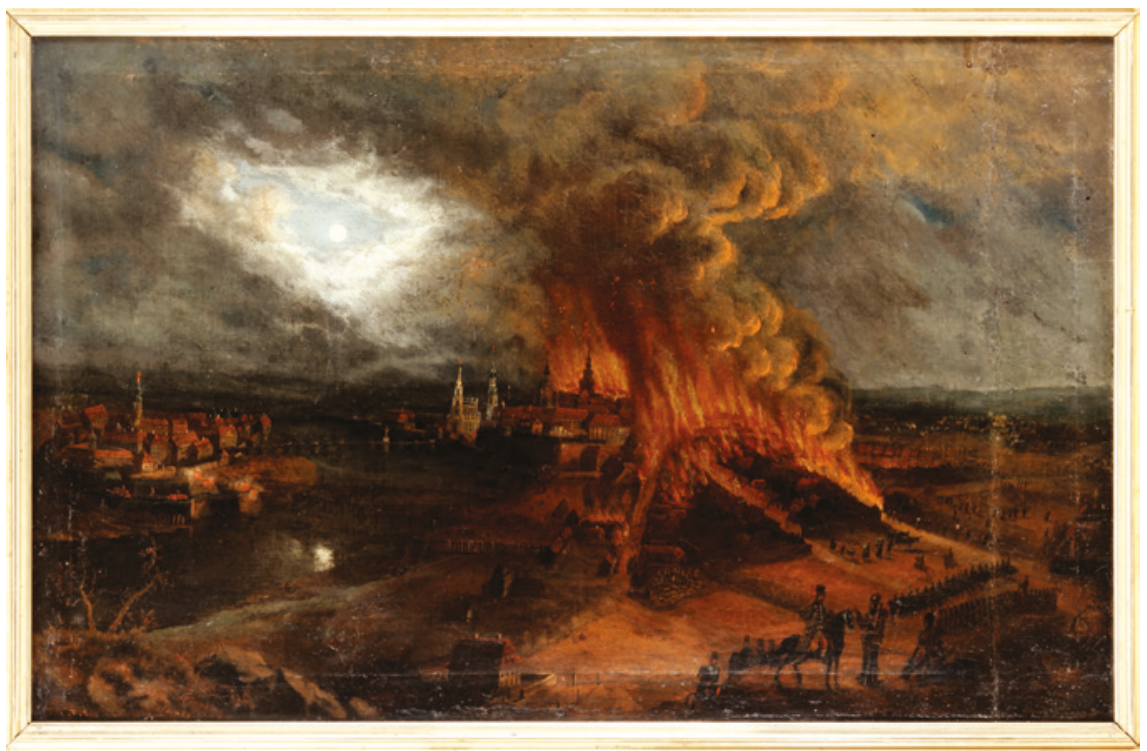

FIGURE 44 Johann Christoph Jünger: Burning of Dresden's Pirna suburb by the Prussian soldiers when the Austrians were approaching to besiege the city, November 10, 1758 (Staatliche Kunstsammlungen Dresden 1978/k 248)

background of a natural-scientific geognostic discussion of time; the earth's age and the origins of its form also invoked the still-open debate regarding Neptunism vs. Vulcanism. In most cases, small depictions of a few "disaster tourists" appeared in the foreground, so that the observers of the paintingthrough the doubling effect of observers observing - could reflect their own external position regarding the disaster in accordance with theories of the sublime. ${ }^{249}$

Johann Christoph Jünger's $175^{8}$ depiction of the fire set by Prussian occupiers in the Dresden suburbs (instigated by the Austrians' advance during the Seven Years' War) is executed in precisely this way and demonstrates that in the Enlightenment schematization of visual perception, the war-induced city

249 For the period around 1750, see the small synthesis by Jörg Trempler, "Katastrophen." Ihre Entstehung aus dem Bild, Berlin 2013. For Volaire cf. Émilie Beck-Saiello, Pierre Jacques Volaire, 1729-1799: dit le Chevalier Volaire, Paris 2010, pp. 113-146 for the interpretation of the several Vesuvius pictures he painted during his stay at Naples after 1768; for Hackert (most important Vesuvius picture of 1774) cf. Monica Leonardi, "Der Vesuv und die phlegräischen Felder. Feuer, Wasser, Schwefel und Gestein", in 'Kennst Du das Land'. Italienbilder der Goethezeit, eds. Frank Büttner, Herbert W. Rott, Cologne 2005, pp. $255^{-271 .}$ 


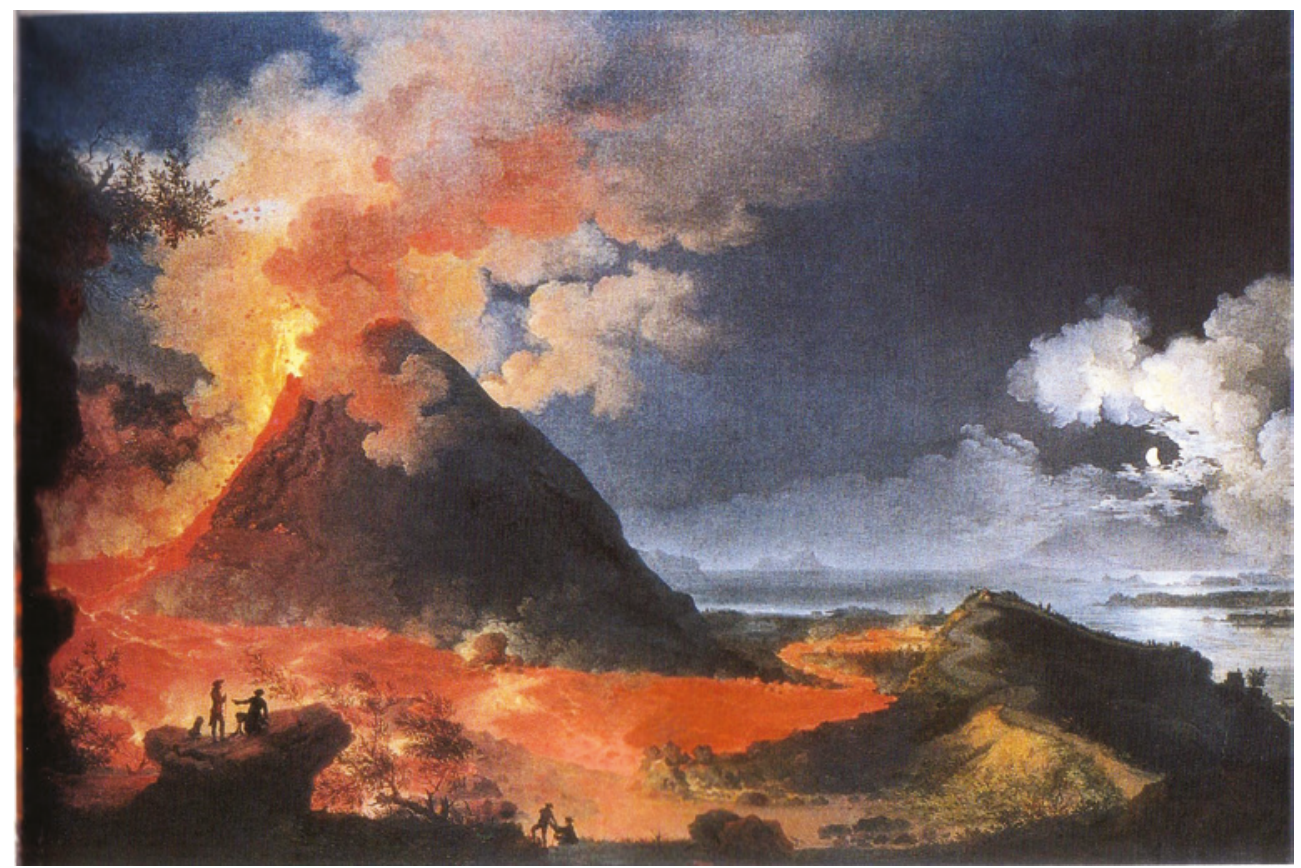

FIgURE 45 Pierre-Jacques Volaire, "Outbreak of the Vesuvius" 1774, Compton Verney Manor, Warwickshire, England

fire is also categorized as a natural disaster, just like a volcano eruption, and clarifies why absolutizing the fire event stands in the center of such paintings as the actual affect-directing mover (Figure 44, 45). The Dutch school had, in practice, already anticipated this sublime aesthetics of disaster in some respects before the theory arrived. In print graphics, capturing the danger and horror of the fire, the stupendous moment itself, becomes increasingly central. If there were a role that the observer could assume, it would be David in a battle against the inhuman Goliath of the fire inferno-not the compassion for a suffering individual human depicted.

What actually occurs is the always increasing attempt to confront the spectators emotionally, and always more powerfully, with the danger of fire in itself, without taking a detour through empathy_empathy for the suffering, the danger, the fear of other people - as was the primary aim of the theory and practice of most poetic tragedy. Even in the engraving of the Reutlingen city fire of 1726 , in which the composition almost produced a symmetry between the high-reaching tongues of flame and the raised arms of the terrified observers, the people remain depicted as small and unindividualized, with their backs facing the viewer. This demonstrates the attempt to directly address the 
simple base emotions of fear in the face of an uncontrollable fire, in contrast to the derivative, specifically culturally coded emotional program..$^{250}$ Thus, in this way, a pictorial language for "disaster" develops in tandem with the linguistic and philosophical concept of disaster in the eighteenth century. ${ }^{251}$

Unfortunately provenance research has not yet come far enough to construct a true social history of the owners of "realistic" landscape and fire paintings and to thereby answer the question of "why" they owned these landscape paintings. ${ }^{252}$ Concerning the broadsheets and engravings of city fires in near or distant cities, however, it has been repeatedly documented that they were used in correspondences requesting support between authorities or to directly solicit donations - thus as media used to appeal for solidarity, rather than merely as remembrance and memorial images like some oil paintings.

The development of the visualization of city fires and the mobilizing power of fire images is thus at least correlative, since temporally speaking, and perhaps even relating causally to a small extent, it contributed to the general development beginning in 1650-1700, which since the eighteenth century, and irreversibly since the nineteenth century, led to the flattening of the peaks in fire frequencies and the spread of the fire gap. It is thus a parallel phenomenon to the somewhat astounding ethically and emotionally manipulative topoi of advertising for fire insurance in the numerous smaller cameralistic tracts and treatises of the eighteenth century, which led to the implementation of the fire funds. The founders of fire funds and fire insurance companies attempted to weld together potential members (cities, villages, and their individual citizens) in institutional associations of risk and solidarity, which were incommensurate and neither spatially nor socially coextensive with traditional relationships because they far exceeded conventional local networks (cf. below Ch. 5 , 1.1). In order to do this, they appealed to the moral responsibility of the individual, the importance of charity and brotherly love, and even the common good of all mankind. Also, it is noteworthy that one transformative effect of insurance institutions - the inauguration and cultivation of more abstract, impersonal relationships than in the old forms of social solidarity—was that

250 J.H. Barkow, L. Cosmides, and J. Tooby (eds.), The Adapted Mind, Oxford 1992.

251 The history of concepts and the history of visualization are two components that should be taken together to create an integrative "History of perception". On the first topic see Mercier-Faivre and Thomas, L'invention de la catastrophe; Olaf Briese and Timo Günther, "Katastrophe. Terminologische Vergangenheit, Gegenwart und Zukunft," Archiv für Begriffsgeschichte 51 (2009), pp. 155-95.

252 Cf. Goedde, Naturalism, p. 142: "Until more work is undertaken on ownership and provenance, it will be difficult to reach conclusions about who owned realistic landscapes and why." 
they necessitated a stronger form of emotional discourse. The technical side of insurance projects - which invokes personal responsibility and collective selfinterest according to a probability calculation involving large numbers, and speaks to the reader's "rational" side through various tables and calculation examples-bills itself as the engine of a new form of supralocal passion related to humanity and mankind, which not only has a life of its own in the literature and art of the time, but also operates on a practical level (cf. Ch. 5, 1.1-2).

Thus the demonstrated tendency in fire visualizations is understandable in the following way: on the one hand there was a development toward a much more direct confrontation with the threat, and on the other hand, due to lack of an offer of intermediary human identification, a move toward a more abstract perception of fire. This is analogous to the somewhat dialectic combination between an emerging individual concept of personal responsibility for future losses and anticipating care for one self (Eigenvorsorge) with the far more abstract deindividualization of social bonds that the insurance institutions effected. Above all, the exceptional state of the disaster as an avoidable phenomenon first revealed itself in concrete contours through developments in artistic representations of catastrophes - as a contrast to the expected normal state of safety and security, disasters became comprehensible and capable of being experienced visually. Such visual (in addition to linguistic and semantic) conceivability was necessary so that the "normal secure society" always had its abhorrent opposite placed before the eyes: a new quality of the sphere of security could only arise by refining and emotionalizing the image and the concept of the threat to security.

\subsection{Ground Zeros: Visualization and Time Horizons}

The previously discussed developmental lines regarding urban fire visualizations addressed the autonomy of the disaster as an image object and its related impact on affect. Even here there were close links to the area of practical fire prevention and also to notions of resilience and disaster management- just as within the aesthetic development itself, a striving toward the chorographicgeographical, scientific form of landscape and city visualization was apparent. As will be discussed below, the analysis of the visualization of the burned cities themselves - the ground zeros-relates even more closely to the areas of fire policey, resilience and reconstruction management:253 even before the autonomy of an aesthetics of ruins, based not only on Classical ruins, but also

253 Cf. the quick response to the 2001 catastrophe Joan Ockman (ed.), Out of Ground Zero. Case studies in urban reinvention, Munich 2002. 


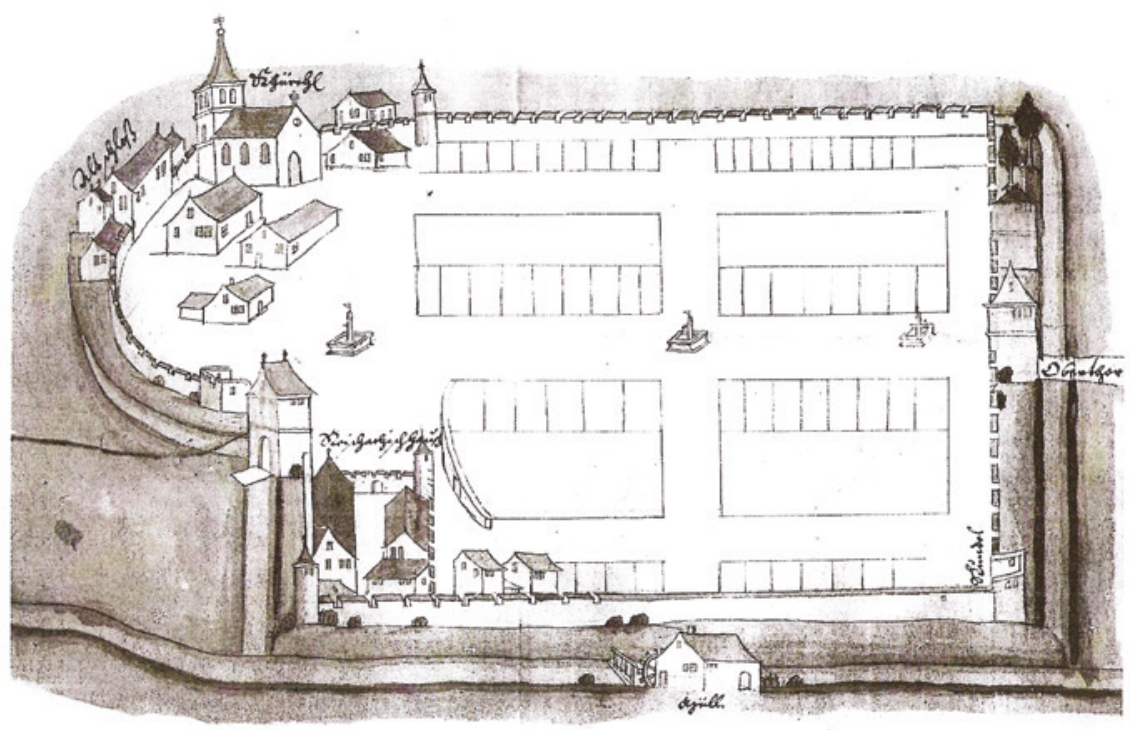

FIGURE 46 Map of the city of Elzach indicating the burned part, Landesregierungsarchiv Innsbruck, Ferdinandea 31, Freiheiten, Faszikel 35 Elzach

on actual ruins, the urban technical/architectonic view of the destroyed area of the city had been long established. A comprehensive longitudinal study is, however, still absent. Studies on urban cartography and on hazard mapping in the nineteenth century do exist, ${ }^{254}$ as do studies of individual city fires and postfire cartography, zoning, and mapping along with other map types used in the Prussian bureaucracy of reconstruction. ${ }^{255}$ For the purposes of the argument unfolding here concerning a long-term epochal change, however, I can only attempt to sketch some aspects and vertices of this development, focusing on the question of how certain temporal horizons and images of danger and safety have been inscribed onto images of the city. In addition to the development of the affect-related side of the disaster image and the temporalization of its representation, the question thus arises: what images of a city are created in a post-disaster situation and, potentially, in the anticipation of disasters?

254 Mark Tebeau, Eating Smoke. Fire in Urban America, 1800-1950, Baltimore 2003, pp. 89-125; Mark Monmonier, Cartographies of Danger: Mapping Hazards in America, Chicago 1997; Niels van Manen, "Les plans d'assurance incendie de Goad: Cartographie des risques d'incendie et normalisation des risques industriels (1885-1903)," Le Mouvement Social 249 (2014), pp. 163-85.

255 See below Ch. $5,2$. 
One of the earliest representations (of the type that later became common) of a burned area that I am aware of comes from the city of Elzach in the Breisgau area of Anterior Austria- a territorial city under the rule of Archduke Ferdinand at the time of the fire (September 27, 1583) (Fig. 46). The fire destroyed almost the entire building stock of this small town of forty houses, five towers, and forty-three barns; as was often the case, these structures were still contained within the city walls. The fact that such a map was created here was probably due to the great distance between the city and its government (Elzach was located on the right bank of the Rhine and northeast of Freiburg/Br., while the Anterior Austrian government was in Ensisheim [on the left bank of the Rhine and north of Mulhouse/France] and the seat of the ruling Archduke was in Innsbruck). ${ }^{256}$ The map was sent to the Archduke along with a request for donations to support reconstruction, and was intended to serve as documentation of the reconstruction plan. ${ }^{257}$ The name of the artist is not known but its type corresponds to the aerial-view cityscape, specifically to that of the southern German late Renaissance painting of the handicraft milieu, as could also be found in Augsburg or Nuremberg. Elzach is located in the immediate vicinity of the Lordship of Triberg, whose ruler was Lazarus von Schwendi. Schwendi also pledged reconstruction aid for Elzach. ${ }^{258}$ He was known to have read Machiavelli's early writings and was probably the most important military and tactical late-humanist advisor of Emperor Maximilian II. He led the siege of Magdeburg in 1550, and had, at this point, just organized the Anterior Austrian and Alsatian militia according to a late-Renaissance military model. ${ }^{259}$ Without knowing more details about this specific fire among the many hundreds of city fires

256 On the politico-institutional context of the Austrian estates in this area, see Kurt Gustav Speck-Nagel, Die vorderösterreichischen Landstände im 15. und 16. Jahrhundert, 2 vols., Karlsruhe 1991.

257 Landesregierungsarchiv Innsbruck, Ferdinandea 31, Freiheiten, Faszikel 35 Elzach, attached to the letter of the council to Ferdinand on November 17, 1583, Josef Weber, Zur Geschichte

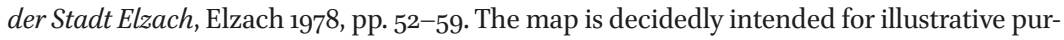
poses "welchermassen dies Stättlein Elzach wiederumb in guter Ordnung und Creuzgassen damit auf chünftiger Füersnot, die der Allmächtige allerorts verhüten wolle, bessere und gelegenere Rettung angeschafft und zu erbauen sein möchte." (ibid., p. 53).

258 Weber, Elzach, p. 55 .

259 On Schwendi's reception of Machiavelli, see Lina Baillet, "Schwendi, lecteur de Machiavel," Revue d'Alsace 112 (1986), pp. 119-97; Thomas Nicklas, Um Macht und Einheit des Reiches. Konzeption und Wirklichkeit der Politik bei Lazarus von Schwendi (1522-1583), Husum 1995; on Schwendi's contribution to the Landrettung (defense organization of the country) of Upper Austria, see Cornel Zwierlein: Discorso und Lex Dei. Die Entstehung neuer Denkrahmen im 16. Jahrhundert und die Wahrnehmung der französischen Religionskriege in Italien und Deutschland, Göttingen 2006, pp. 738-50. 
and reconstruction organizations, it is not surprising, in this context, that the mapping of the empty reconstruction area, including designating foundations for rebuilding, reveals the influence of a rudimentary chorographically and geographically trained form of a rather "southern" Renaissance provenancethe artist was presumably trained in mathematical measurement practices. The map, in light of its finishing technique, is certainly comparable to works by surveyors-for example, those by Tilemann Stella during this time in southern and central Germany. ${ }^{260}$ These reflections are necessary to contextualize the map's exceptionality: it is surprisingly early example of this form of recording. More elaborate aerial-view depictions of burned areas and the subsequent mapping of burned sections and the parceled plans for reconstruction, which thus point toward the future, are otherwise common only at the beginning of the seventeenth century — at least for central Europe and according to all the related literature of southern and western Europe regarding maps and legends. ${ }^{261}$

A map some decades later, which shows a clear developmental step and essentially already reflects the type common throughout the seventeenth and eighteenth centuries, is from the Lower Saxon town of Herford in 1638 . Although Herford had formally declared its independence from the empire in the wake of the Thirty Years' War, it was quickly subject to loss of sovereignty and occupation again. In the middle of the war, a major fire broke out on July 25 stylo veteri (August 4/5 Gregorian) which, uncharacteristically, was not war related. The city issued a letter of appeal to the Duke of BraunschweigLüneburg, who had served since 1637 as patron, asking him to intercede with the emperor to request aid. Along with this letter, a map was included, clearly marking the areas of the burned buildings in red, apparently in order to visually illustrate for the Duke the damage that was later notarially estimated at

26o The classical case study for a German territorial "Landeserfassung" (survey) is Kersten Krüger, Finanzstaat Hessen 1500-1567. Staatsbildung im Übergang vom Domänenstaat zum Steuerstaat, Marburg 1980, which analyzes the developments even prior to the "Ökonomische Staat" (economic state [however meaning 'budget' or 'survey']) of Wilhelm IV, the first German survey that could compete with western and southern European comparative cases. For the cartographic work that was produced in the same contexts and with similar purposes, see Axelle Chassagnette, "Mettre en carte: fonctions pratiques, intellectuelles et sociales de la cartographie allemande au XVIe siècle," in Isabelle Pantin and Gérald Péoux (eds.), Mise en forme des savoirs à la Renaissance. À la croisée des idées, des techniques et des publics, Paris 2013 .

261 One might presume that something similar has been already in use in Renaissance Italy — as the idea and sketches of (undestroyed) planned cities (Planstadt) were common there since at least the early sixteenth century-however, I have found no hint of this either in sources or in the literature related to the city, art, or the history of disaster until today. 


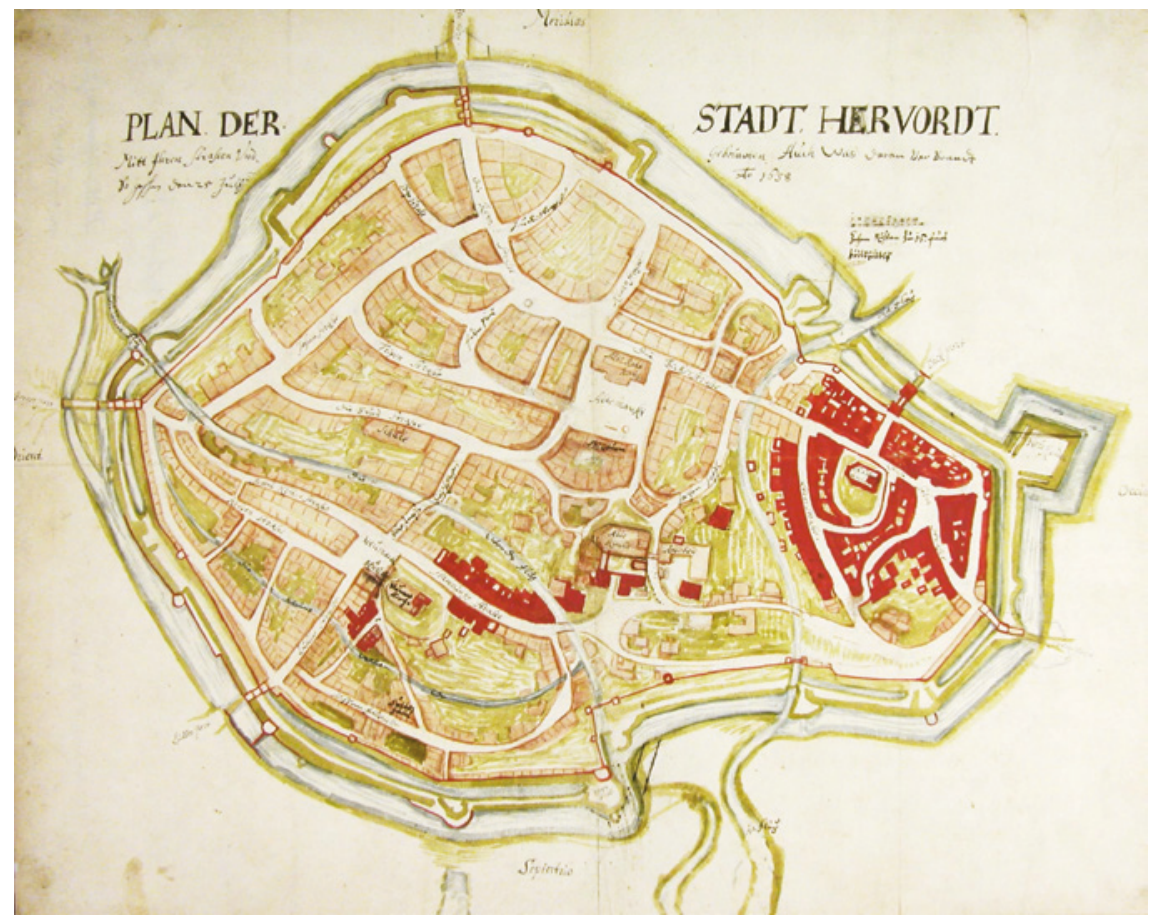

FIGURE 47 Plan der Stadt Hervordt Mitt Ihren Strassen vnd Gebäwen, Auch Was daran verbrandt, so geschen den 25July A.o 1638, Map of Herford after the fire, showing the part destroyed in red, Staatsarchiv Hannover, Notariatsinstrument des Hermann Schmackepepfer von 1643

150,00o Rtl. — just as the Elzach map served to illustrate the damage for the distant Archduke Ferdinand. Unlike in Elzach, the Herford map is not characterized as a blueprint for reconstruction. However, the Herford map was apparently able to draw on an earlier, recently completed town survey, which was created by the engineer Antonius Bose during the reconstruction of the defensive city wall in 1626; thus, the mapping of the burned areas corresponded to the then most modern techniques of the art of military surveying (Figure 47). It was not until 1827 that another survey-based city map was produced; this gap in surveying was not atypical for such small towns. ${ }^{262}$

This type of fire damage map is absolutely identical to maps sketching areas of fire damage known from news broadsheets concerning the most famous early modern city fire-London 1666. In the case of London, the aerial-view maps with markings of the areas damaged by fire are essentially derived from

262 Johannes Kretzschmar, "Zur Geschichte Herfords im 3ojährigen Kriege. Mit einem Plane der Stadt von 1638," Westfälische Zeitschrift 58 (1900), pp. 5-29. 
engravings made directly after the fire. ${ }^{263}$ The engraving made by Wenceslaus Hollar after a very quick survey in December 1666 (printed in 1667) is most well-known ${ }^{264}$ and served as the starting point for the competing reconstruction plans by Wren, Eveyln and Knight. ${ }^{265}$ These engravings were based on accurate surveys and visual maps, which already existed for a big metropolis like London. Measurements of the burned areas were taken during the reconstruction process by Robert Hooke and others, but since this process took over two decades, ${ }^{266}$ these measurements did not form the basis for the ground zero images immediately published after the fire in 1666.

Initially, the function of these early visualizations of the damaged areas in aerial-view city maps was primarily to illustrate the massive damage, in particular, for the purpose of advertising for support and preparing to solicit donations - they served only secondarily as the rough basis for mapping sketches for future planning in the London case. In small towns such maps emerged as a response to the distanced communication between city magistrates and ducal patrons: cities needed to present an image of themselves and their damaged state to the lords who were "looking at them." It was no accident that the first of these maps appeared, in the case of London, on a Dutch broadsheet, thus within the framework of early modern news and solicitation communication. As late as 1726 the ground zero image for the Reutlingen fire of 1726 was expressly formulated as a "begging letter" by Augsburg engraversthus detached from the city itself. In contrast to contemporaneous Prussian situation maps, it also had no relation to the reconstruction; it was thus intended purely for the purpose of providing a visualization of the dramatic range of destruction in order to solicit donations. ${ }^{267}$ The presence of earlier such examples always seems to be related to the random, or in the case of a metropolis

263 Probably the earliest "ground zero" of the London fire is illustrated on a Dutch broadsheet by Marcus Willemsz Doornick, printed in 1666, Michael Cooper, "A More Beautiful City": Robert Hooke and the Rebuilding of London after the Great Fire, Stroud 2003, p. 102.

264 Repeatedly reproduced, for example in Derek Keene, "Fire in London: Destruction and Reconstruction, A.D. 982-1676," in Körner, Wiederaufbau, pp. 187-211, 19o and Tinniswood, By Permission of Heaven, Fig. 17.

265 These are reproduced in Stephen Porter, The Great Fire of London; Cooper, A More Beautiful City; and Tinniswood, By Permission, figs. 18-21.

266 For surveying work after the fire, see, especially, Cooper, A More Beautiful City, pp. 95220 and Michael Cooper, "Robert Hooke's work as surveyor for the City of London in the aftermath of the Great Fire," Notes and Records of the Royal Society of London 51 (1997), pp. 161-74; $5^{2}$ (1998), pp. 25-38, 205-220.

267 The electoral/Bavarian councilor Johann Thomas von Rauner, whose own feudal property made him a neighbor to the city of Reutlingen, commissioned the engraving with the Augsburg engraver Gabriel Bodenehr for the purposes of inspiring donations; see Schwarz, "Der große Reutlinger Stadtbrand," p. 21. 


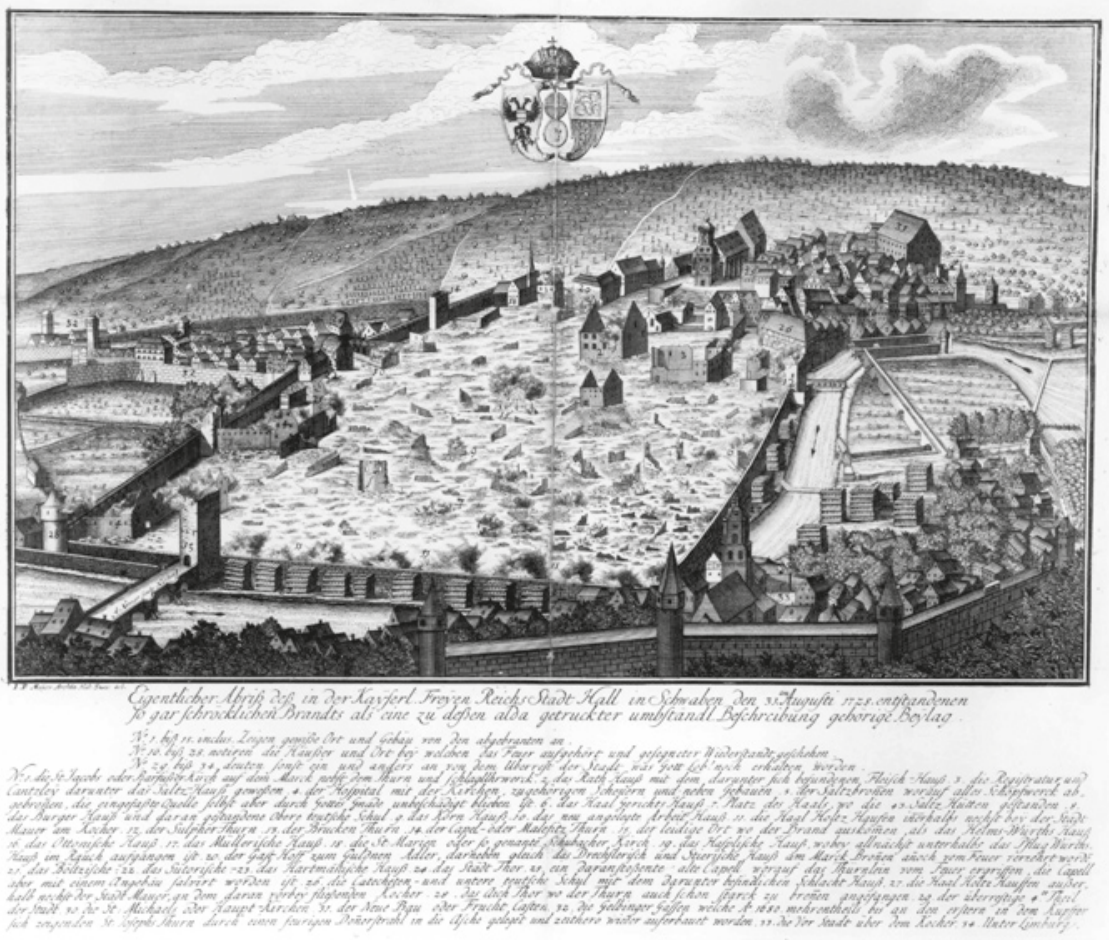

FIGURE 48 Engraving of Schwäbisch Hall's Ground Zero after the city fire of 1728 by the architect I.P. Meyer (Stadtarchiv Schwäbisch Hall, Grafiksammlung S1o/ 2340, thanks to Sara Wiest for sending a reproduction)

like London easily explainable, availability of a current survey associated with mapping the city for some purpose.

In addition to such aerial-view renditions marking damaged areas as ground zeros in survey-like city maps and representations, there were also prospectustype representations of burned cities, which appeared with any great regularity only after the mid-seventeenth century (early eighteenth century for central Europe). These featured ruins in copper engravings and in oil paintingsbeginning, in this sense, with Hollar's London prospectus of the city silhouette. ${ }^{268}$ The best examples for Germany for our purposes are Schwäbisch Hall (1728, Figure 48), Gera (in 1686 as well as 1780, Figure 49, 50), and Göppingen (1782, see above Figure 24).

268 This is currently in the British Museum; the woodcut has been reproduced in Timothy Baker, London. Rebuilding the City after the Great Fire, London 200o, p. 2f. 


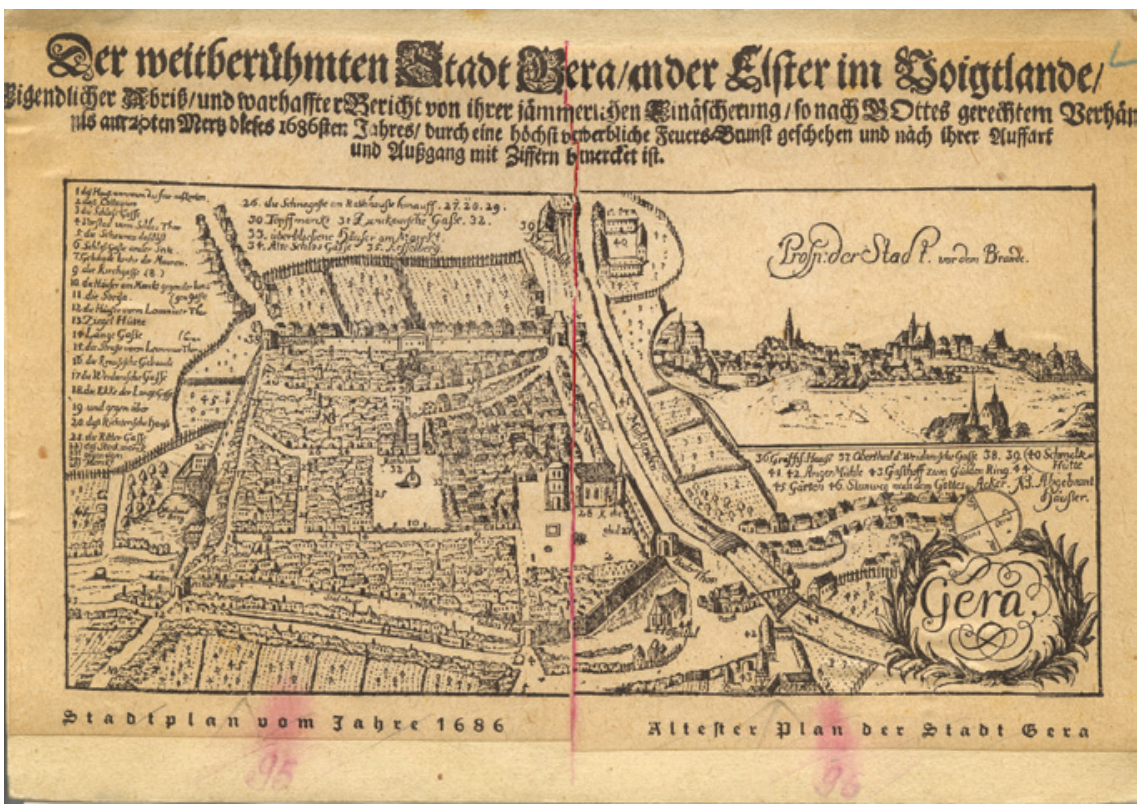

FI GURE 49 Engraving on a single-leaf broadsheet Der weitberühmten Stadt Gera/ an der Elster im Voigtlande/ Eigendlicher Abriß [...] Leipzig: Justinus Brandt 1686, Stadtarchiv Gera, A 1505b (facsimile reprint twentieth century, Ao105)

In Schwäbisch Hall, we see the city's coat of arms, with the imperial crown and the double-headed eagle, both signs of the Holy Roman Empire and of the city's immediate status, above the disastrous scene of destruction. The picture has, evidently, no immediate technical function for the rebuilding of the city as in other cases discussed below, but it serves as a memory of that sorrowful moment of complete annihilation of one of the most important south-western imperial cities — and this also in the form of a deep-strata memory: while now the center is completely destroyed, the engraver remembers the part to the left which had resisted the flames this time (number 32, the Gelbinger Gasse), when it had already been destroyed in 1680. Thus, the city consists nearly more or less of nothing, nothing that concerns material existence on earth is firm and stable, even the parts that still seem to be strong and stable, built of stone, are just built on older ground zeros: a city consists not of deeper and deeper strata of stone, earth, memories and life, but of a succession of layers of ground zeros.

However, it seems typical that such sophisticated representations of the zeroness of the city, its reduction to the immateriality of its living community by force of the material destruction of its stock of houses, is to be found perhaps most in such small and mid-size cities that retained their immediate status and remained 


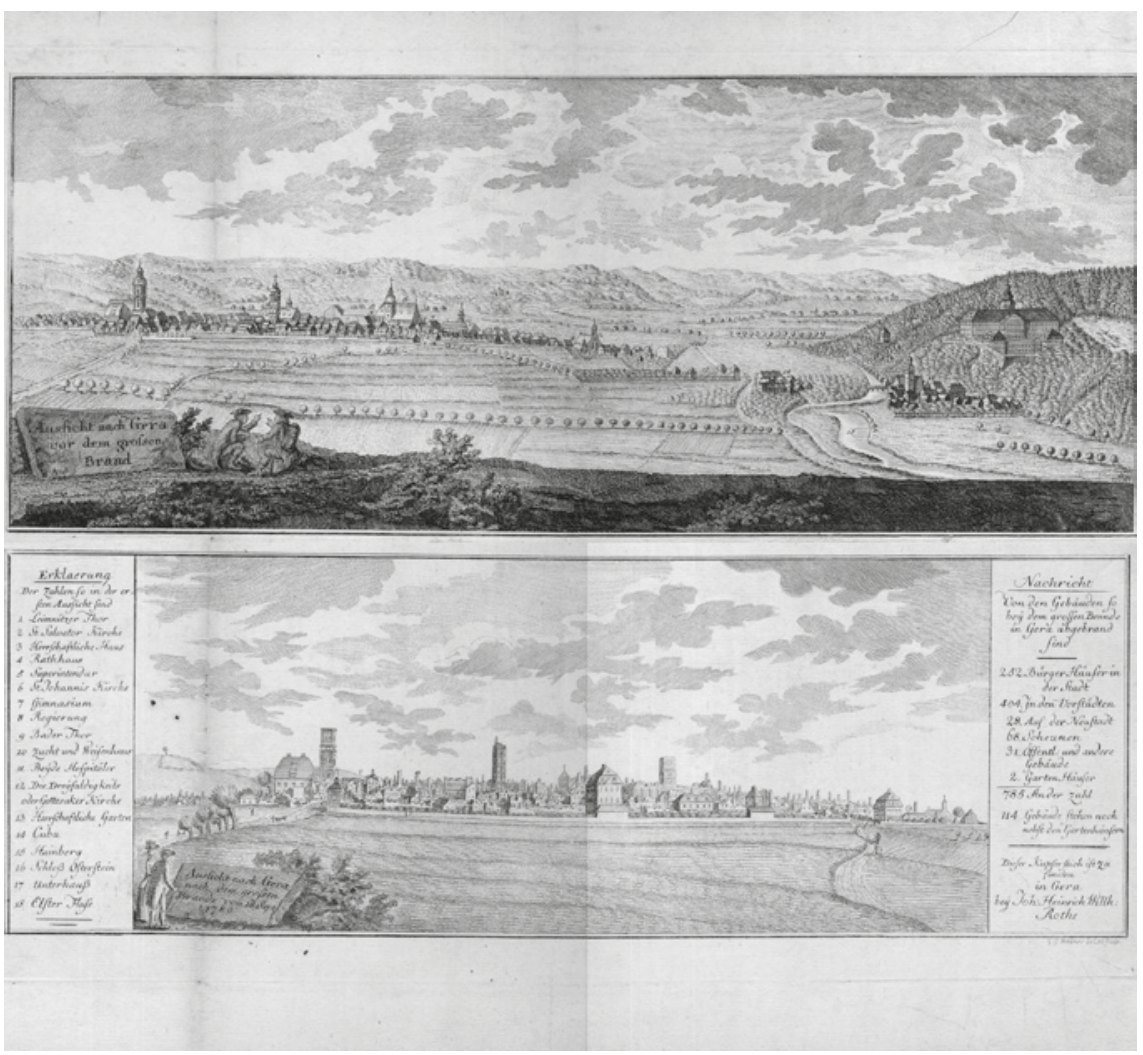

FIGURE 50 Engraving Aussicht nach Gera vor dem grossen Brand-Nachricht von den Gebäuden so bey dem grossen Brande in Gera abgebrand sind, Gera 1780, by G.G. Endner (sculp.), printed by Johann Heinrich Roth, Stadtarchiv Gera, A5630

quite proud and self-conscious as is the case of the southwestern imperial and proto-bourgeois cities, who since the Middle Ages had a tradition of cultivating their individual identity as a collective body of citizens. In contrast, there are no such (or far less or only sometimes exceptionally) equivalent representations for the many hundreds of small towns of northern and northeastern Germany that burned after 1650: Gera distinguishes itself here from other country towns as a city of residence for the Count of Reuss - it was not one of the small-scale territorial cities of the large Prussian or Saxon territories that were administrated more or less in an equalizing manner. This representational form, which has no functional relationship to reconstruction planning, but rather only served memorial purposes by invoking consternation and dismay and horrific memories of the past disaster, appears to arise only in those municipal communities which practiced an "early-civic" cultivation of city consciousness and collective memory. 
The elaborate ground zero memorial belongs to those cities, which Walter Mack has characterized as "hometowns", going beyond the constitutional typology of imperial, free, and rural towns and cities. These were often located in the southwestern region; ${ }^{269}$ the almost generic, state-governed and -engineered small towns in the north and northeast were fully subject to the lords of that region.

In the north-east, however, other developments were special and to some extent were advancing and innovative with regard to the home-towns of the south-west. In Prussia, earlier than in the largest south-western territory of Württemberg, a kind of professionalization and bureaucratization of the reconstruction administration emerged in the cameralistic management that was not found elsewhere in western Europe. This led to a standardization of the map-like representation of cities in case of fire, which transformed a possibility that was only a happy accident before $165^{\circ}$ into standard and normal practice: after every fire, the extent of damage was surveyed and entered onto a situation map, which was then combined with a reconstruction map for future planning, either in a single map using several colors or in two separate maps. This will be discussed in the next section (Ch. 3, 3) as an example of yet another aspect of the reconstruction process in Prussia, which later took place in other German territories, especially in the second half of the eighteenth century. Due to the high cost, this process was more effectively implemented through the overarching state in territorial cities than it was in the many small, poor, southwestern German towns of the seventeenth and eighteenth century, which were not supported by any rich country lord. Concerning the standard application of fastidious engineering surveys of such burned cities, these otherwise hardly significant communities paradoxically possessed a higher status in terms of implementable innovations and administrative techniques than many of the traditional imperial cities of the South. Curiously, there is also no comparable standardized bureaucratization of these operations leading to a standardization of these ground zero images known for France ${ }^{270}$ — even though France was recognized as the leader, or at least a very active player, in terms of both engineering and surveying technology ${ }^{271}$ and also regarding tendencies toward the increasing intervention of the state in post-disaster aid during the

269 Mack Walter, German home towns: community, state, and general estate, 1648-1871, 2nd ed., intro. James J. Sheehan, Ithaca 1998; Cf. the special issue Central European History 47, (2014), ed. Robert Mark Spaulding.

270 Similarly, in France there was also no state administrative system of 'prophylactic' anticipating fire funds. Cf. below Ch. 5, 1.1.

271 Josef W. Konvitz, Cartography in France, 1660-1848: science, engineering, and statecraft, Chicago 1987; Hélène Vérin, La gloire des ingénieurs. L'intelligence technique du XVIe au XVIIIe siècle, Paris 1993. 
eighteenth century. ${ }^{272}$ It is thus not the cities that abstractly created their own images of damage and sent them to the city rulers, but rather the sovereign who ruled those cities (approximately 78 of which belong to the Kurmark and Neumark areas, to mention the Prussian central provinces alone) as objects to be managed who created these maps - the ground zero was seen from this high and central administrative perspective, which surveyed the urban network of the entire territory. The aerial perspective, ${ }^{273}$ which has been common since the Italian Renaissance and particularly since the rise of Dutch city cartography (extending even to aerial views with the painting in of cloud shadows long before airplanes could indeed take such photographs in reality ${ }^{274}$ in the seventeenth century, was popularized by and for self-assured city republics. Insofar as the thriving city could be captured as a whole, the standardized form of the ground zero image as the mapping of the aggregate area of destruction is found precisely where the view from above corresponds to a bureaucratic-planning view of the ruler of his cities and his welfare-like management of them. ${ }^{275}$

Whether images of ruins and fires served a memorial function or served an administrative and city planning function as a map of the situation and

272 Quenet, Tremblements, pp. 265-305.

273 For the corresponding history of the development of the concept of the metropolis, see Cornel Zwierlein, "Durée, stabilité et grandeur urbaine: de la cité humaniste à la métropole moderne," in Élisabeth Crouzet-Pavan, Denis Crouzet, and Philippe Desan (eds.), Cités humanistes, cités politiques (1400-1600,), Paris 2014, pp. 237-51.

274 Peeters, "De stad".

275 Jaeckel presents a number of postfire maps in the appendix of his unfortunately unpublished thesis. These maps, are based, in part on earlier surveys of the mediate and immediate cities of Kurmark and Neumark starting with the 1720s for Crossen in 1721, Luckenwalde in 1724, and then resuming in midcentury. Jaeckel's dissertation advisor Reinisch explored the case of Neuruppin in his own monograph, which also reproduces the relevant maps from 1787 (Ulrich Reinisch, Der Wiederaufbau der Stadt Neuruppin nach dem großen Brand von 1787, Worms 2001). Thomas Spohn's “'Sollen recht ordentlich bauen sonder Resoniren. F W'-Hausbau und Stadtplanung unter preußischem Einfluß, dargelegt am Wiederaufbau der märkischen Städte und Flecken im 18. Jahrhundert," Der Märker 39 (1990), pp. 191-206, 250-61 presents similar maps following the same pattern for Prussian administrated Westfalian cities, including Schwelm 1722, Unna 1723, Plettenberg 1724, Breckerfeld 1727, Hagen 1724, a four-colored, relatively carefully drawn map by mathematics student Nicolaus Stell for Hamm 1734 and a rough idealized map of reconstruction for Lüdenscheid 1724. Additionally, one could mention the destruction and reconstruction maps for Lebus 1723 , conceived according to the same bureaucratic pattern (rendered as an engraving in Johann Christian Wellmann, Das von der göttlichen Regierung an denen Mordbrennern, welche in der Nacht zwischen den 19. und 20. May 1723 die Lebusische Vorstadt zu Franckfurt an der Oder [...] angesteckt bewiesene Denk-Mahl [...], Frankfurt an der Oder 1725, f. b3V); on the Lebus fire of 1801 the files in BLHP Rep. 2 $\mathrm{S} 55^{26}$ contain information about the preparation of the situation map by Conducteur 
reconstruction, the premoderns were only aware of the depiction of past damages, and future images of cities to be built anew-the destruction was in the past and the future was worthy of being illustrated as a complete city. In the modern era, in contrast, a further, basically new type of image developed where different forms of potential future destruction are inscribed into the city and its representations. Risk or hazard mapping is a visualized anticipation of the possible ground zero of a city and was first developed in its embryonic form by English fire insurers in the last third of the eighteenth century.276 Examples of such map types will be introduced in the last chapter, when the global expansion of English insurers will be addressed in order to conceptualize this new epochal threshold concerning the relationship between fire and safety in modernity. If one would not explain the colors differently, it would be possible to judge the 1638 Herford map with red markings based on a previously existing map of the city (see above, Figure 47), and for instance the far later 1858 map of the Istanbul district of Pera with red markings of relevant quarters on a printed map engraved by Stolpe through Agent Wood of the Sun Insurance Company, as belonging to exactly the same type of map (see below, Ch. 6, 2, Figure 69). In one case, however, the damage shown had already occurred; in the other case, future prognostics were sketched on and into the map: houses judged to be definitively less risky and better-built are shown, which, in the anticipation of a possible disaster, thus appear to be more resistant to damage. Risk mapping quickly assumed more sophisticated forms, and cities were separated into zones of different levels of risk - that is, in terms of their potential vulnerability to destruction.

Using immensely more powerful visualization techniques, today's forms of electronic hazard mapping capture a variety of risks and future scenarios that can be projected onto city spaces as well as other spaces-concerning not only fire or flood damage risks, but also zones denoting a higher risk of racist violence and other forms of risk. The potential of the disaster and the ground zero state is always visually inscribed within the conception of the present and future state of a city. ${ }^{277}$ There is little research specifying which cartographic

Lietzmann; from the context of the Seven Years' War regarding Küstrin $175^{8}$ the damage reports serve as preparatory work for the survey in BLHP Rep 3 Nr. 106o3/1; for Peitz 1758 there is still a map in a file archiving a similar procedure in BLHP Rep 3 Nr. 10376. For other German regions there are very similar maps; for example, Tübingen 1789, Tuttlingen 1803 (fire reconstruction and geometrical reconstruction maps), the Electoral Trier-NassauOranienburgian village of Camberg 1798 , and the Electoral Bavarian-Sulzbachian Markt of Erbendorf 1796. In the late eighteenth century this becomes the common pattern in all regions and also the smallest dominions. The temporal development and the special position of the Prussian administration in this area is, in any case, clear, in spite of incomplete source preservation and further gaps in the responses to the inquiry of 1800 communities.

276 Van Manen, Les plans, p. $17 \mathrm{lf}$.

277 Cf. note 261 above. 
models were used to create the first fire insurance risk maps-in central Europe there are no surviving maps from the time of the cameralist fire funds: cameralist administrations did not produce such anticipations of zones that were more likely to be damaged in future than others. However, it can be shown that an intermediate, transitional element of this development is obviously a differentiation and refinement of reconstruction maps, which were crafted at the moment of the destruction and aimed at consequent reconstructionthere was no projection of future scenarios onto the map independently of the destruction. The degree of detail of the damage measured and plotted on the map increased, however, and the way to represent the current state of ground zero after the disaster became more sophisticated. Nicolaus Stell, a student of mathematics, drew a map of Hamm after $43 \%$ of the 456 houses of the city had burned down on September 22, 1734, distinguishing with four colors the burnt houses (red), the remaining (blue), the zone of garden and unbuilt zones (yellow) and the public church places, the cemetery and the streets (white). ${ }^{278} \mathrm{He}$ did not distinguish the types of building, however, nor degrees of destruction, nor did he integrate the measurements of the estates (Figure 51).

W. Dornstein drew a plan of the town of Peitz, destroyed on December 24, 1758 by order of the Kurmark War and Domaine Chamber (Kriegs- und Domänen-Kammer), the mediate administrative institution existing for each Prussian province depending on the central Generaldirectorium: he distinguished between houses in parts not at all touched by the fire (in Latin numbers) and those hit by the fire (in Arabic numbers). He marked those houses better preserved than the others within the zone hit by the fire with red ink. He measured all the ground-plots of each estate, listing both types of houses in a large legend. A picture of the city emerged which offered everyone one quick look at a comprehensive representation of the damage (Figure 52).

Some of the more sophisticated situation maps distinguish building materials/types quite precisely, and in particular the roofing material (straw or stone), and thereby point out a fundamental fact of fire risk in the buildings still standing. Reconstruction often ordered or encouraged stone buildings in the place of older half-timbered and thatched-roofed construction, and thus a lower or higher future fire risk for the remaining part of the city was visualized-as, for example, in 1756 for the Mecklenburg Grevesmühlen in 1756 (Figure 53):279

278 Heinz Stoob, "Grundrißbild und Entwicklung der Altstadt Hamm bis 1830," in Herbert Zink (ed.), 750 Jahre Stadt Hamm, Hamm 1971, p. 21.

279 The fire has nothing to do with the Seven Years' war as the date might suggest: on March 25, 1756 the former shoemaker Christian Miltz, who maintained himself as a distiller of brandy, had caused the fire by careless handling of his distillery, 59 houses, 8 barns and many stables were burnt. By order of the Duke of Mecklenburg, the detailed plan of the 


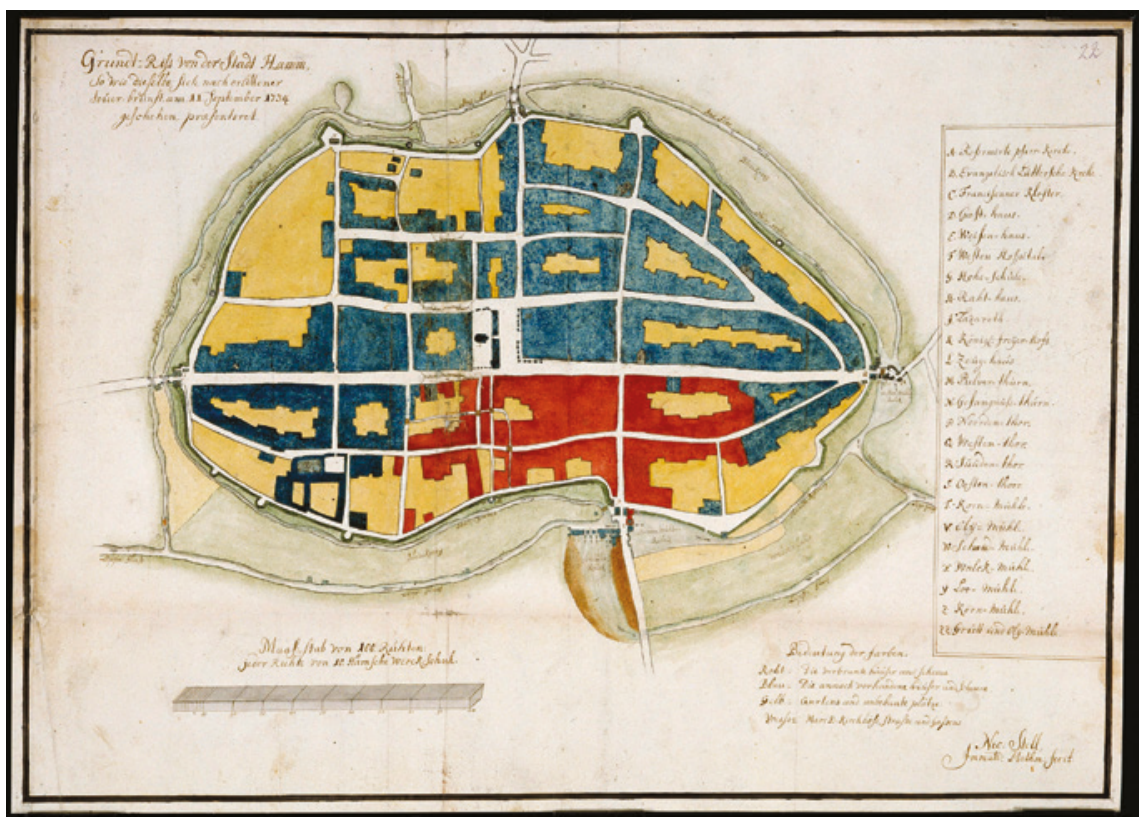

FIGURE 51 Groundplot of the city of Hamm (Grundt-Riss von der Stadt Hamm, so wie dieselbe sich nach erlittener Feuer-brunst am 11. September 1734 geschehen praesentiret) drawn by Nicolaus Stell, cf. Spohn "Sollen recht ordentlich bauen", p. 201

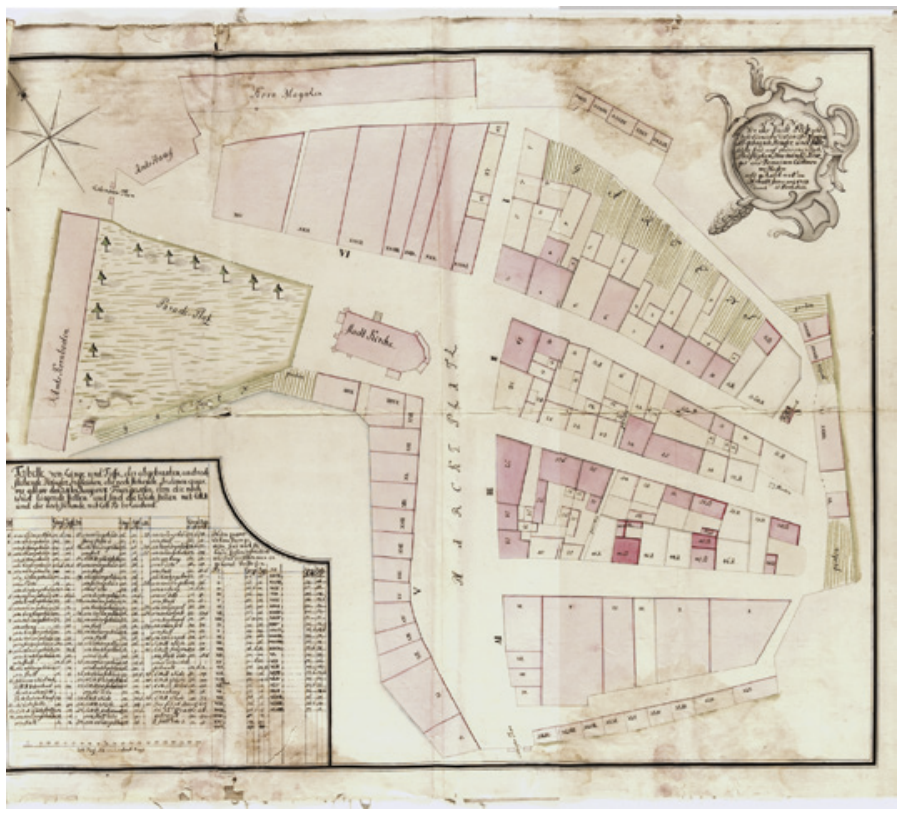

FIGURE 52 Plan of zones of destruction and possibility of rebuilding by W. Dornstein of the Fortified City (Festungsstadt) of Peitz after the fire of June 23, 1758, BLHA Potsdam, Rep. 3, Nr. 10376 

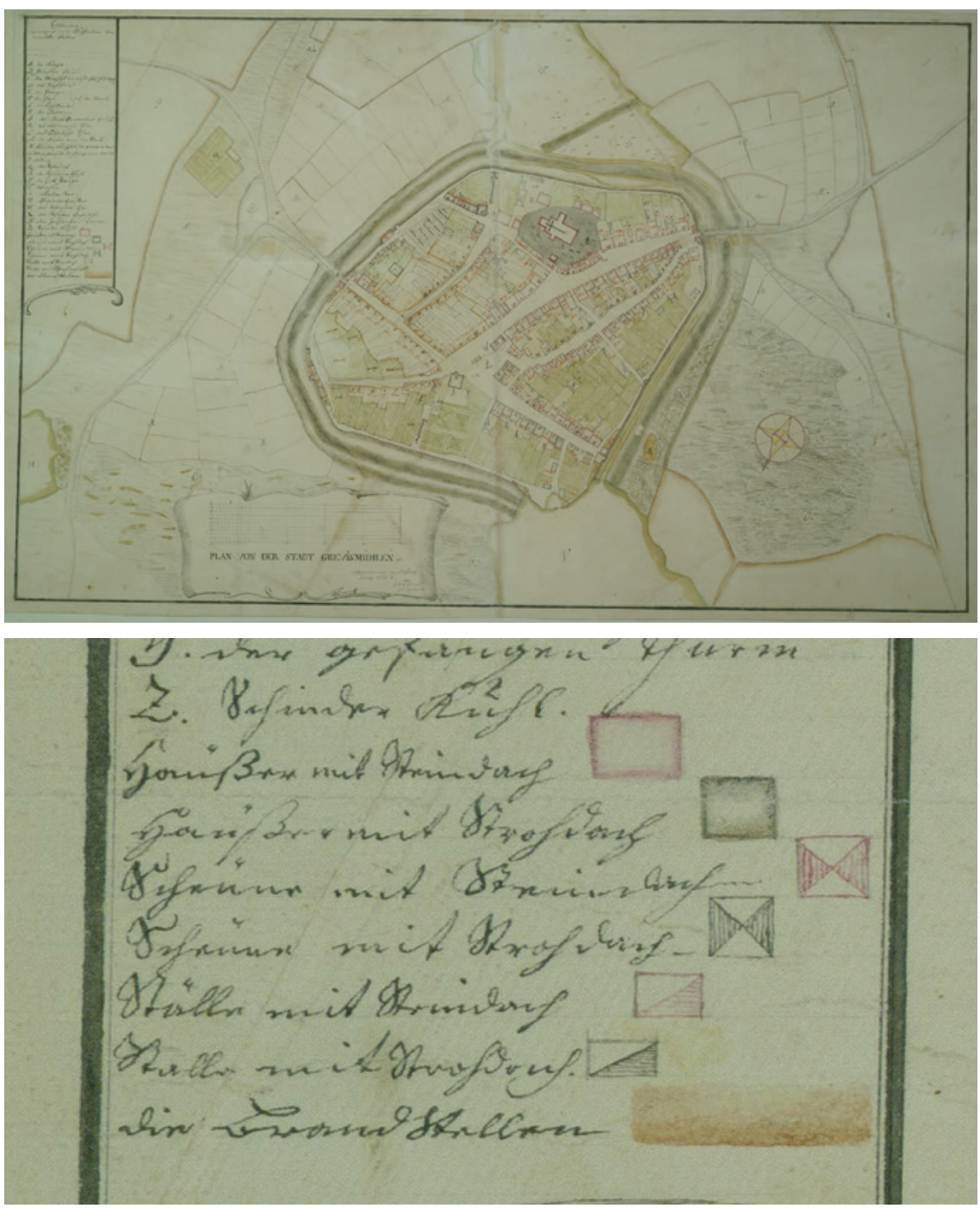

FIGURE 53 Map of Grevesmühlen (Plan der Stadt Grevismühlen), 8ox6o cm, drawn by military surveyor and artillery lieutenant J.D.F. Blume, early June 1756, Landeshauptarchiv Schwerin 2.21-1 Geheimes Staatsministerium und Regierung, Nr. 2009

The mapping expert from the ducal army's artillery distinguished six types of houses next to the zones of burned houses ("die Brandstellen"): 1) living houses, 2) barns, and 3) stables with each either "stone roof [Steindach]" (tiled or brick roof), or houses with thatched roof ("Strohdach"): although this was a post-catastrophe map, it was still mapping-somehow and in a very rough way — the present and future degree of risk for given zones of the city. 
Narrative and tabular explanations of past destructions are, of course, common throughout the eighteenth century, but visualizations are by no means common and not yet systematized - even less so for small independent cities or those in territories which had not yet developed a systematic form and bureaucratic scheme of recovery and rebuilding as was the case in Prussia since the early eighteenth century (cf. below Ch. 5, 1 and Ch. 5, 2). However, within the cameralist state management of central Europe, starting points do appear for the emergence of such a new administrative image of risk for cities and of a new level of complexity and interconnection of the time horizons concerning the visualization of "disaster." The image of the possibility of future disasters is beginning to be constantly co-present.

In addition to the previously addressed development of the autonomy of the disaster as the autarchic image-subject itself (Ch. 3, 2.2), and to the refining of the affect control on the side of appeal and expression, this important development at the level of disaster consciousness and the simultaneous continual visual processing of "disaster potential" thus emerges as a further decisive element on the cognitive side. Taken together, a striking change in the visualization of city fires and fire disasters manifests itself from the late Middle Ages into the early nineteenth century, once again with a particular break or phase of concentration in the developmental trajectory at the end of the seventeenth and the beginning of the eighteenth century.

\section{Developmental Trends of "Real-Assecuration": Fire Policey, Construction}

The previous section offered an important level of analysis that involved tracing the emergence and changes associated with how the threat of fire was perceived. We will now shift our attention to the ways in which this threat was approached and managed practically. Fire policey constitutes the classical operational field of these practical efforts. As mentioned at the start, Leibniz ingeniously labeled this area of security production as "real-assecuration," (i.e., security of and in physical reality) in contrast to "verbal-assecuration" (i.e., security granted by insurance institutions) (cf. Ch. 4, 1.2). The procedures related to the production of security before and after a putative disaster are both quite distinct and also systematically tied to each other. The major sections of

city was drawn by the artillery lieutenant Blume who was paid 27 Reichstaler and 43 shillings, Landeshauptarchiv Schwerin 2.21-1 Geheimes Staatsministerium und Regierung, Nr. 2009. 
Chapters 4 and 5 will address the transformation of fire prevention and firefighting specifically in this sense, in the context of the development of a new insurance-based system of security, which appeared around 1680-170o.

\subsection{The Security Regimes between the Late Middle Ages and the Enlightenment and between the City and the Territories}

From the smallest of villages to the largest of cities, all premodern communities were keenly interested in fire prevention as one of the most important matters influencing basic survival. In principle, the fire policey measures implemented were always the same: there was a specific set of firefighting equipment - a triad of leather buckets, hooks, and ladders. While the first rudimentary precursors of city fire ordinances had emerged by the late fourteenth century, in the fifteenth century, they began to acquire a highly detailed form - for example, the Cologne ordinances of 1452, which served as the foundation of the entire early modern development of fire policey in that imperial city. Primarily, this ordinance divided the city into areas of responsibility, often according to parish districts. It also detailed storage locations for firefighting equipment and the duties of the citizen for the maintenance thereof.

Policey research has paid relatively little attention to fire policey and in more recent times it has investigated it almost entirely in respect to the territories, in spite of the fact that the most significant innovations in this area until well into the seventeenth century clearly concerned cities. ${ }^{280}$ The main tasks regulated by fire policey were the constant evaluation of the functional capacity of firefighting equipment (i.e., eliminating buckets with holes and broken hooks and ladders), replacing it when necessary and, beginning in the eighteenth century, maintaining large fire hoses, the so-called "serpentine fire hoses" (Schlangenfeuerspritzen). Fire ordinances were often related to building ordinances, watchman ordinances, fire fund ordinances, and insurance ordinances. While in earlier years they were frequently integrated into one single ordinance, in

280 M. Ventzke, "Fürsten als Feuerbekämpfer: Handlungsmotive einer sich wandelnden Hofgesellschaft am Ende des 18. Jahrhunderts," in Id. (ed.) Hofkultur und aufklärerische Reformen in Thüringen. Die Bedeutung des Hofes im späten 18. Jahrhundert, Cologne 2002, pp. 223-35; André Holenstein, “'Gute Policey’ und lokale Gesellschaft. Erfahrung als Kategorie im Verwaltungshandeln des 18. Jahrhunderts," in "Erfahrung" als Kategorie der Frühneuzeitgeschichte, Munich 2001, pp. 433-5o; Achim Landwehr, Policey im Alltag. Die Implementation frühneuzeitlicher Policeyordnungen in Leonberg, Frankfurt am Main 2001, pp. 262-273; André P. Holenstein, “Gute Policey" und lokale Gesellschaft im Staat des Ancien Régime. Das Fallbeispiel der Markgrafschaft Baden(-Durlach), Tübingen 2003, pp. 727-49. 
later periods they were differentiated according to specific subject matter. The ordinances reflected different levels of expectation and horizons of concernfor example, concern about fires caused by tobacco smoking in the eighteenth century. ${ }^{281}$ In order to provide a reasonably representative impression, I will compare two cities, Cologne and Hamburg, and a territory - the Prussian central province of Kurmark.

\subsubsection{Cologne: An Important Medieval Imperial City ${ }^{282}$}

In Cologne, the first fire ordinance, which seems to have had relatively little impact, dates from the year $1360^{283}$ and was written not on parchment, but already on a piece of paper. ${ }^{284}$ However, the foundational fire ordinance was not written until June 21, 1451, and it was this ordinance that ultimately ruled the entire early modern period - its effects were still relevant in the city's Prussian era of the nineteenth century. ${ }^{285}$ This fire ordinance, originally written in Low German, formed the initial part of the so-called "fire scrolls" (Brandrolle), as translated into official High German-the collections of norms, council decisions, and instructions issued to the four city "fire lords" (Brandherren). Further decisions made by the magistrate relating to fire prevention were added later in accordance with article 17 of the old fire ordinance. ${ }^{286}$ The structure of this ordinance was based on the sixteen, and later twenty, Cologne parishes. ${ }^{287}$ With the church heads as leaders, each parish was required to provide and maintain firefighting devices ( 282 buckets, 66 ladders, 35 hooks). This number was increased in the eighteenth century (as of 1729: 744 buckets, 72 ladders, 43 hooks). From 1711 on, city militia captains were also obliged to provide 12

$281 \quad$ Nassau-Weil fire ordinance 1751.

282 The archival research for this section was carried out in 2007/08; verifying some details was no longer possible due to the collapse of the Cologne city archives.

283 Karl Härter (ed.), Repertorium der Policeyordnungen der Frühen Neuzeit, vol. 6, Reichsstädte 2: Köln, 2 vols., ed. Klaus Militzer, Frankfurt am Main 2005, no. 81; Walter Stein (ed.), Akten zur Geschichte der Verfassung und Verwaltung der Stadt Köln im 14. Und 15. Jahrhundert, 2 vols. Bonn 1893-95, vol. 2, pp. 26-28.

284 Paper was introduced just around that time in Cologne, the first paper document in the archive dates from 1343. Thus, fire policey administration obviously belongs to the new segments of municipal administration that needed frequent communication and that were handled now by help of the new writing material, cf. Zwierlein, "Gegenwartshorizonte im Mittelalter," p. 34 .

285 Stein, Akten, vol. 2, pp. 365-69.

286 For example, in HStA Köln V+V N17, f. 11v-12v; N21, f. 12v-13r; N23, f. 11 r.

287 In the fire scrolls of Hieronymus Schophorn $\left(177^{6-79)}\right.$ the numbers for 20 parishes are significantly altered in contrast to the 16 parishes of the old order, HStA Köln V+V N 23; in the fire scrolls of Johann Frantz Hyacinth Canot of 1776 , the old numbers are listed in f. 3 r, as in $\mathrm{N} 21, \mathrm{f} .7 \mathrm{v}$. 
buckets each (at 54 captains, 648 additional buckets). ${ }^{288}$ From 1741 on, ${ }^{289}$ the 25 guilds were also required to provide 30 buckets, one ladder, and one hook (thus 725 buckets, 25 ladders, 25 hooks). Visitation logs and notes from 1729, $1742,1753,1763,1769,1787$, and 1794 show that these target values were, for the most part, not attained; either because the leather buckets were rotten and unusable or because there were simply not enough present. ${ }^{290}$

The maintenance of firefighting equipment was flanked by many, in part continually repetitive, edicts. For example, there was an edict against possessing uncontrolled amounts of gunpowder (April 26, 1583), ${ }^{291}$ and one regulating the possession of gunpowder (not more than 12 pounds per private residence, March 29, 1647, renewed on August 20, 1787. Regulations changed under French occupation (dated 6 Vendemiaire an III), returning to the 12-pound regulation in the Prussian ordinance of January 11,1815$){ }^{292}$ There was also an edict prohibiting the dangerous Cologne custom of a fire on the night and day of the "St. Peter ad vincula" (St. Peter in Chains) celebration on August 1 of every year to commemorate the liberation of St. Peter from prison (Acts 12: 1-11). ${ }^{293}$ In periods of great drought and heat, the council also regularly ordered every house to provide a water barrel in front of the house for fire-extinguishing purposes, imposing a fine of one gold florin for noncompliance. ${ }^{294}$

Beyond these regulations, the fire ordinance was also flanked by a published "alarm" (Auflauf) ordinance, i.e. an ordinance regulating the behavior of fire watchmen, as well as the organization and logistics of fire extinguishing methods - while not dated, it is probably from about 1580 . Accordingly, the fire bell at the city hall was supposed to be rung "henceforth no longer for a single fire but only when multiple fires break out at the same time."${ }^{295}$ As in every city,

288 HStA Köln V+V N 12, p. 18.

289 HStA Köln V+V N 86o, f. 6v.

290 In 172915 o buckets were lacking; in 1742 there were a total of 576; in 1753 355; in 1769, 716 buckets, 101 ladders, and 82 hooks were lacking; in 1787 there were 348 buckets, 41 ladders, and 25 hooks lacking; HStA Köln V+V N 336, N 86o, N 862.

291 HStA Köln Edikte 6 Nr. 44.

292 HStA Köln Edikte 6, Nr. 45-48.

293 July 21, 1581, July 25, 159o, July 29, 1680, July 20, 1681, July 26, 1684, July 20, 1689, July 28 , 1698, HStA Köln, Edikte 6, Nr. 138, 139, 172, 178, 179; Edikte 27 f. 38r-v, 196r-v. Cf. BächtoldStäubli (ed.), Handwörterbuch des Aberglaubens, 10 vols., Berlin 1929-42, vol. 6: 1526 .

294 Other than the St. Peter ad vincula edicts and also November 11, 1580, June 27, 1659, July 1, 1684, July 28, 1688 (HStA Köln, Edikte 6 Nr. 171, 173, 174, 175.).

295 HStA Köln Edikte 6, Nr. 140, Art. 7; Härter and Militzer, Repertorium, no. 2067-dated 1550 without any clear justification; through comparision with other ordinances in this group of edicts, I would estimate the date of printing to be closer to the 1580 os. Further printings: January 5, 1604, March 25, 1633, March 12, 1635, January 3o, 1642, March 14, 1659, October 6, 1688 (Härter and Militzer, Repertorium, no. 141, 142, 143, 157). 
an especially important developmental threshold in fire policey was the acquisition and installation of the new "serpentine fire hoses" (Schlangenfeuerspritzen). In an edict from June 10, 1665, there was already talk of "water sprayers" (Wassersprützen), and an admonition that "in every parish one of those commonly useful sprayers should be placed, for which donations should be collected."296 Of course, leather fire hoses cannot yet be intended here. When in a decree of February 1 , 1679, the advice of the parishes was given to establish "for common necessity, a water sprayer" through donations, it appears only as a repetition of the older ordinance, probably regarding pipe sprayers without leather hoses. This was, however, obviously not heeded, since on September 9, 1722, an edict was released that it "would be highly necessary that the fire and water sprayers should be purchased with accompanying leather channels" and, accordingly, the council once again decreed "that one should be bought for each parish and militia unit"297

The decisive input of practical knowledge came in 1682: on April 27 it is noted in the council protocol that "the model of a large hose, useful in times of fire ... from Amsterdam up to now described and engraved in copper [has been] brought forward." This discovery was then conveyed to the treasurer and the council-affiliated Fire Chief Owell for evaluation. ${ }^{298}$ In fact, these engravings, used by the brothers Jan and Samuel van der Heyden to extol the virtues of their invention and to advertise the pressure-pump water sprayer with movable leather hose ("snake"), can still be found in the Cologne city archive (Fig. 54-57). Though the air chamber that allowed the continous flow of water while pumping was an earlier invention, ${ }^{299}$ the combination of the whole together with the movable hose was a major technological step forward at that time mastered only by the van der Heydens and only by them distributed in such a professional way. The invention had first been tested in 1672 in Amsterdam and in 1682, when the model finally reached Hamburg, it was already being widely distributed throughout Amsterdam. ${ }^{300}$ This advertising prospectus can also be found in Aachen. ${ }^{301}$ In Aachen as well as Cologne, the council had the instructions translated into High German; thus it can be seen how carefully the engraving was examined: ${ }^{302}$ The van der Heydens sold

\footnotetext{
296 HStA Köln Edikte 6, Nr. 177.

297 HStA Köln Edikte 6, Nr. 159.

298 HStA Köln, Rpr. 129, f. 95r.

299 Cf. below Ch. 4, 1.2.2, p. 299.

300 Cf. for literature above, Ch. 3, 2.2.4 after note 232.

301 In the otherwise identical copy in the Stadtarchiv Aachen RA II Allg. Akten 1068; cf. the reprint in Kraus, "Der Aachener Stadtbrand", p. 78, which does not include the price tag.

302 HStA Köln, V+V N 864: the above report (Berigt) still includes the printed "Instructie, rakende't Onderhoud en Conservatie der Slang-brand-spuiten" and the printed price tag
} 


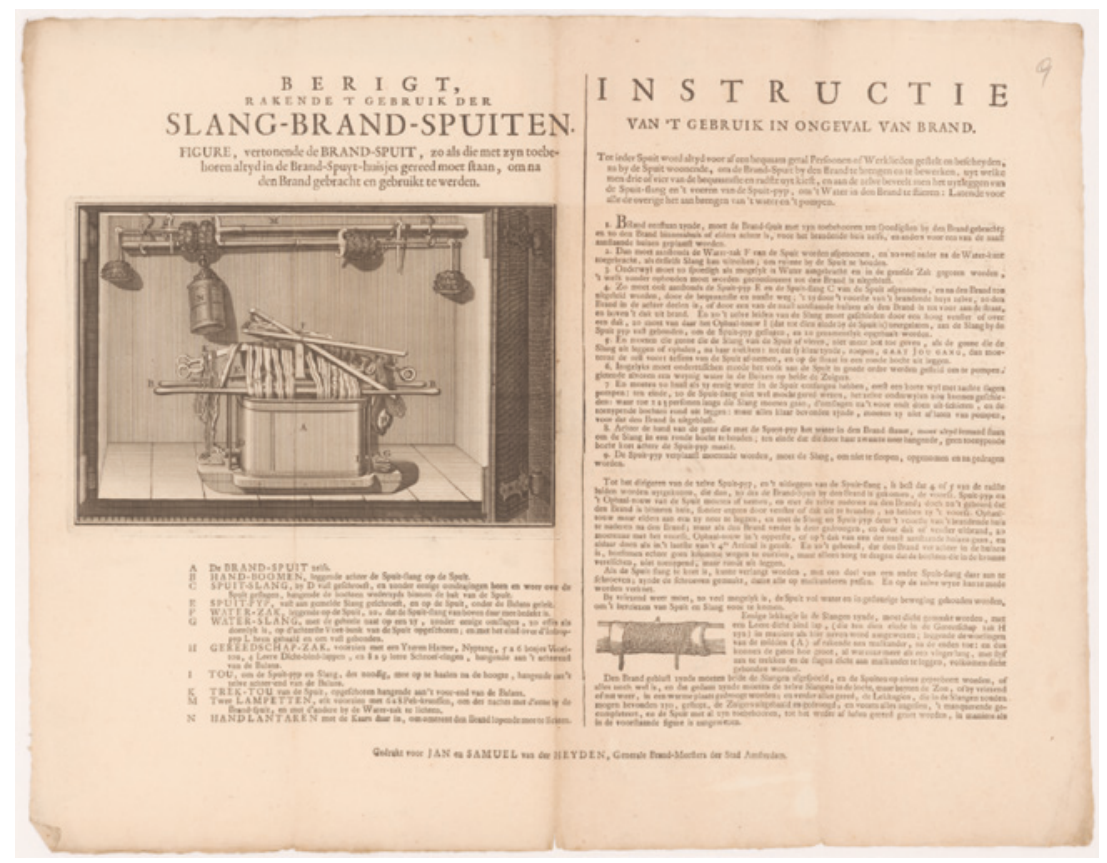

FIGURE 54

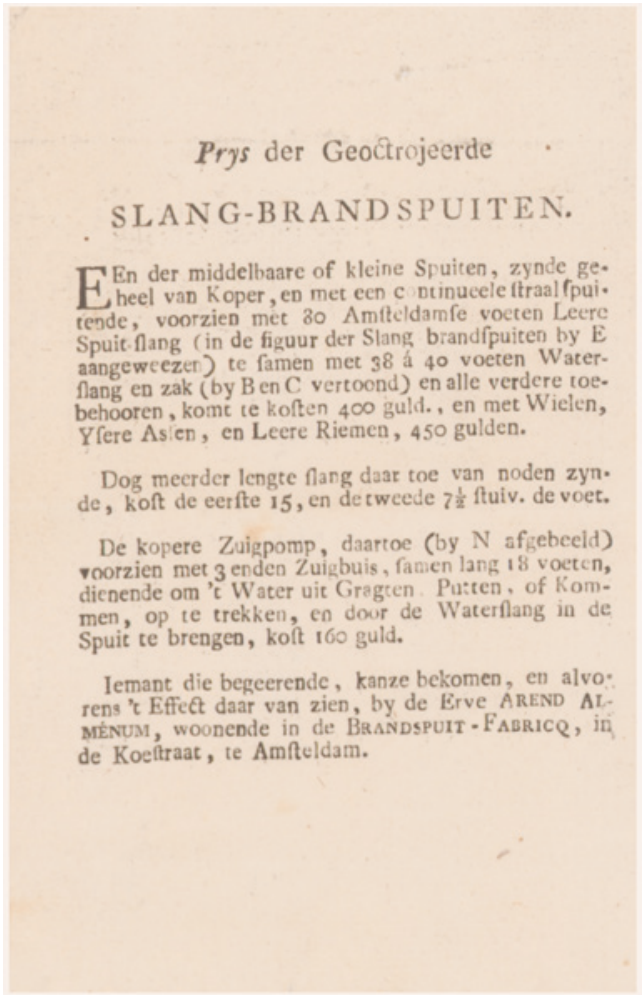

FIGURE 55

\section{FIGURES 54 TO 57}

Jan and Samuel van der Heyden: Advertisement sheet for the serpentine fire hoses, sent to German city magistrates (1682) with details of the construction, and how to use (Fig. 54), a printed price note (Fig. 55), care and maintenance instructions (Fig. 56, p. 194), and with a German translation of the legend (Fig. 57, p. 195), HStA Köln V+V N 864 
INSTRUCTIE, rakende't Onderhoud en Confervatie der Slang-brard-fpuiten:

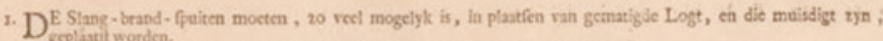
Ecplantit worden.

2. En ten miniten vier malen in ' $\mathrm{J}$ Jur gecinfectect en gercinigr werden, aldes:

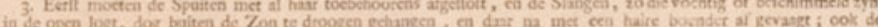

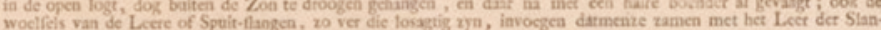

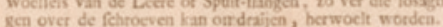

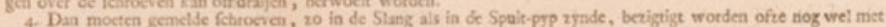

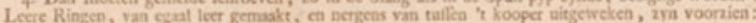

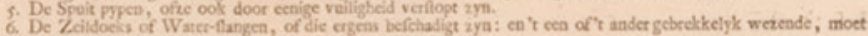
antionds vertolpen wordor

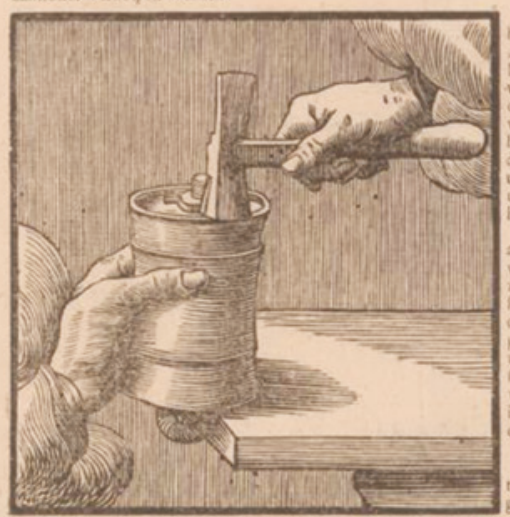

7. DeZuigers mocten vit de Zuiger - buiten opgehai't, afferaagt, cn des zelfs lecr mes Verkcns reuzel cencert worded. En 20 't gebedrd dit cenig Zniget-

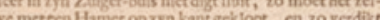
re metecin Hamer op zya kant geisiopt, cil zo verdint

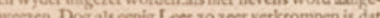
heren. Dog ats wentg Leer zo zect verikrompen is,dat

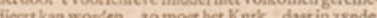
wertian workeal, 20 moct hict Kurk, dar in zynde, vitgenomen, of anders het kurk zelve met ecen dikke: Kunk verwilled worden.

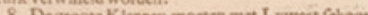
8. De grootc Kippeal mocten met Lywatichoon

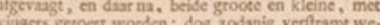

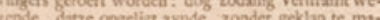

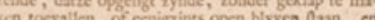

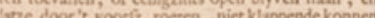

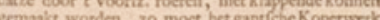
eit de Bal

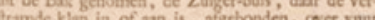

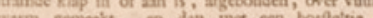

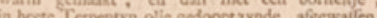

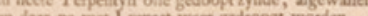

9. Alle rwee Jaren moeten de Spoiten, op ener. 9. Alic tweef arean moetern de Spoiten, op center-

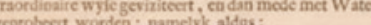

10. Eerit moeten de Leere of Spuit-hangen met Water vernogtworden; dewelke ten dien cinde over ftrast, met de geheele nast, zo veet doenlyk is, boven, tingeled en de Speit-pyp der zelve met een prop gettogt worden, 'T welik

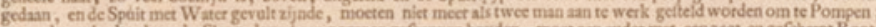

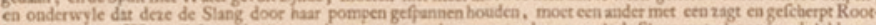
kryt, 20 ergens Water nitrpan, deplantzen daat van net teckenen; Om daar na, als de Slang weer droog is, de lekken te

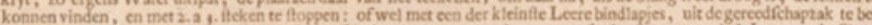

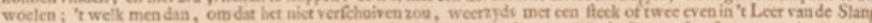

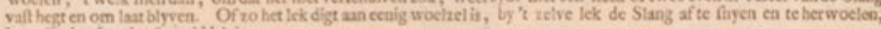
't welk dan ' zekcrile middel in'

11. Tot het proberen san de Spuiten zelf, moeten bethatren de gene die't Water in doen, tot de grootte teri min-

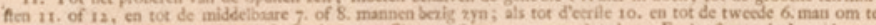
pompen, en an belde 2 . man om de Spait-pyp en Slang te tuuren en op te booden. Ea hectumen in 't probeerea

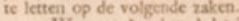

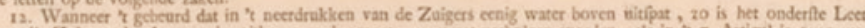
van die Zaiger, daar't water by aitkomt, gekrompen, en moet vertiolpen worden, ats in ' 77 . Articul is angewexen. 13. Zo ter costratic de Zuigers bovea op droog worden, zo is bet bove Leer gekrompea, 't welk mede teverhelpen als in't 7 . Articuli

14. Wanneer bet Water in cen der Zeiger-baitea, by wylen dater wcinig Water in de Speit is, fehuime, dan is

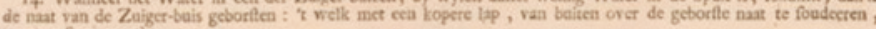
moet geflopt worden.

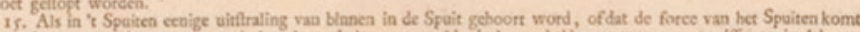

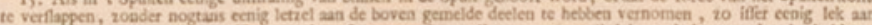
d'onderfic Jecten van't binien Koperwerk, of omtreat de woclingen; on welk lek te vinden men 't gethele binackoperwerk moet vitnemen, dea uitloop van den Helm met kumk itf toe ftoppen, de Zuiger-benizen vol water gicten, en dan eerf met bride de Zuigers gelyk, en dart bia elik bezonder (Alegr met de hand) tiff neet parfles ; als wat. neer her zig wel zal opentaren, om na gelegentheit te vethelpen.

16. En op gelyke wyse als hice vertoont is, moeten ook de Spoiten as tun gebuilk in ongeval van Beand, gerchnigt en soptobeetr worden.

17. Eindelyk mocten de Spuit-@angen jasrlyx, of om de twee jazten, (na menze droog of nog wol in't fimeer bevind) in't warmfte vas de Zome, en ia hooge Zondefehyn, worden goíneert, met fineer dat toe Expres geprepartert om't Leer hoe langs hoe digter te maken en root'i byten vai Ruatten en Muizen te bevryen: ('t welk by "t

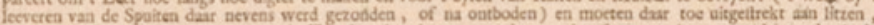
tegen een Muur of Schutting, tegen de Zon Aande gehangen worden; en het fineer zo heet gemalkt aypde als da

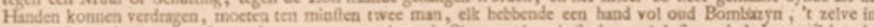

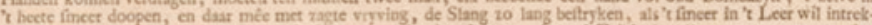
ken: 't welk godann zyode mocten $x y$ de Slangen anilonds afnemen, al oud Zeildoek rollen, en $z 0$ tot aan der

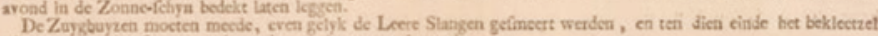
afigenomea, ea gedincert aynde weder oul hera geualt werdea.

FIGURE 56 Jan and Samuel van der Heyden: Advertisement sheet for the serpentine fire hoses, sent to German city magistrates (1682), care and maintenance instructions, HStA Köln V+V N 864 


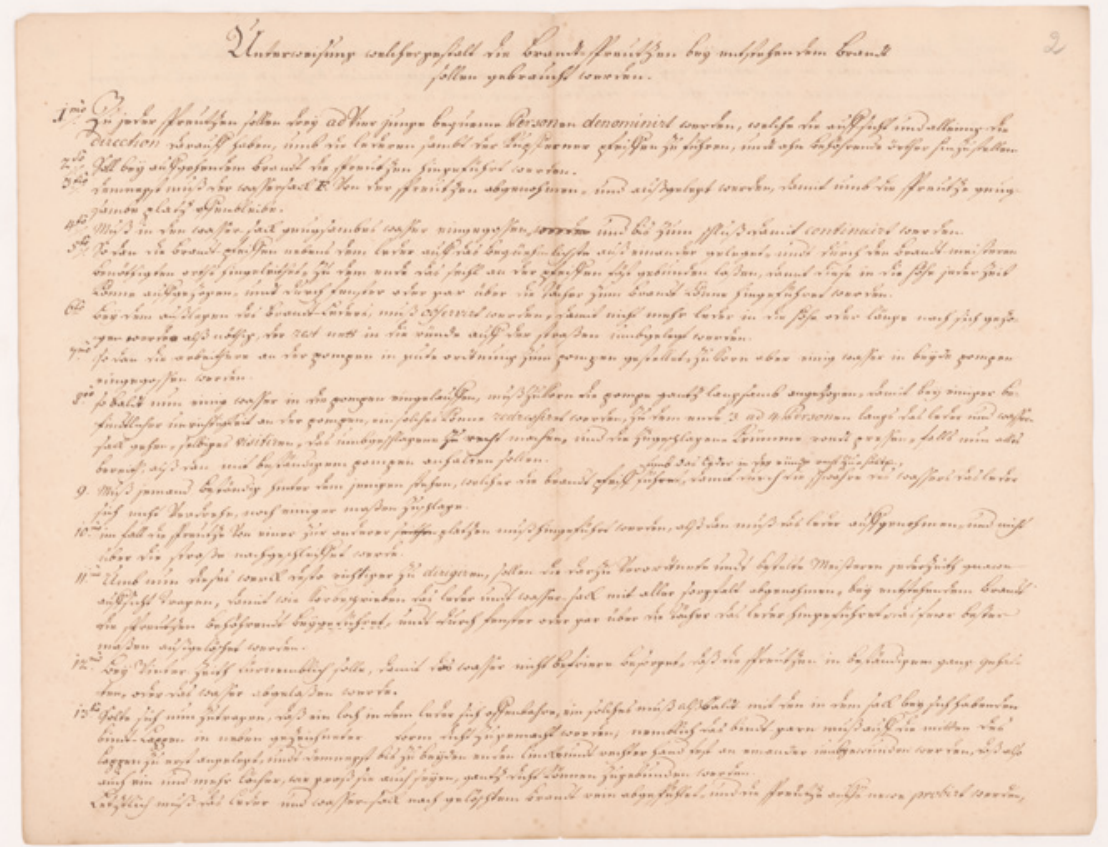

FIGURE 57 Jan and Samuel van der Heyden: Advertisement sheet for the serpentine fire hoses, sent to German city magistrates (1682), German translation of the legend, HStA Köln V+V N 864

the "middelbaare of kleine Spuiten [...] met een continueele straal spuitende [with a continous water stream]" for 45 o gulden and the pomp made of copper for 16o gulden, all to be bought at the "fire hose factory (Brandspuit-Fabriq)".

Exactly how many "serpentine hoses" were bought and precisely when they were employed in Cologne cannot be clearly determined. In the supplementary articles of the fire scrolls in 1709 there is talk of the completion of a new hose, in 1722 there is talk of the task of inspecting the hoses, and in 1727 talk of an additional discovery - in addition to leather hoses, leather pulls which could draw water from distant springs had also been invented in Holland. In

"Prys der Geoctrojeerde Slang-Brandspuiten." Christine Brauner ("Recommendation und Reklame") has undertaken now a more extensive survey of this advertising communication in the early eighteenth century in the small cities of the region like Herford, Duisburg, Bad Salzuflen, Detmold, Xanten. Cf. above n. 233: Advertising was an integral part of what became a network of risk communities, replacing a world of loosely connected solidarity communities (see below Ch. 5, 1). 
1728 a new hose was reportedly completed and another was bought from Holland. ${ }^{303}$ In 1729 there were probably 16 large sprayer-type extinguishers in operation, some "without leather." ${ }^{304}$ In 1801 there were $22,{ }^{305}$ and in 1833 only 20 such extinguishers remained. ${ }^{306}$

The council stimulated engagement in the area of firefighting through performance-based incentives: the first person to arrive with a horse-drawn fire extinguisher after a fire broke out received two Talers (Rtl.), the second 1.5 Rtl., the third 1 Rtl., 307 and the "fire lords" were compensated for every firefighting effort which they actively led. Certain irregularities arose within this system: for each fire, the fire lords basically received a specified number of Ratzeichen ("council tallies") — a Cologne inner-administrative currency or valuation that could be exchanged for actual money. ${ }^{308}$ Between 1758 and 1761 , the four "perpetual" and six rotating fire lords participated in a total of 80 fires and earned 1600 Ratszeichen that were fully paid out. However, contradictory statements led to a report on the matter, which revealed that the fire lords often took credit for firefighting efforts employed in their absence - typically fires extinguished by the homeowners themselves without any assistance from firefighting forces or equipment. Sometimes the lords even took credit for fires that did not happen at all. The anonymous reporter estimated that "hardly one quarter of listed [fires] likely consisted in documented and dangerous fires." ${ }^{309}$

Though relatively rare, such cases documenting the unreliability of some fire figures can certainly shake confidence in archivally demonstrable fire statistics - but in the case of Cologne, there is no significant reliable material available for a longer period. Descriptions in the chronicles are insubstantial ${ }^{310}$ and no fire statistics at all are recorded in the administrative files related to fire policey. This is striking, especially in comparison to Hamburg, where administrators continually worked on writing the "fire biography" of the city. Certainly, one reason for this is the fact that major fire disasters were rare in Cologne, probably because stone architecture was already quite well-developed there,

\footnotetext{
303 HStA Köln V+V N 21, f. 16r-22v.

304 HStA Köln V+V N 862, f. 13r-14v.

305 HStA Köln V+V, N 862, f. 41r: List of 10 Fructidor IX/August 28, 1801.

306 Revised fire ordinance for the city of Cologne, August 1/August 26, 1833, HStA Köln Bibliothek Ec 127, §37.

307 HStA Köln V+V N 23, f. 11 .

308 Cf. Clemens Graf von Looz-Corswarem, Das Finanzwesen der Stadt Köln im 18. Jahrhundert, Cologne 1978, pp. 34-38.

309 HStA Köln V+V N 862, f. 22r-26r, auch V+V N 12, f. 41-46.

310 Several hints are found in Leonard Ennen, Geschichte der Stadt Köln: meist aus den Quellen des Kölner Stadt-Archivs, 5 vols., Cologne 1863-80, vol. 2, p. 507f. and vol. 3, p. 1049 f. for the fourteenth and fifteenth century; in contrast, there is no mention of fires whatsoever for the sixteenth and seventeenth centuries (vol. 6).
} 
although thatched roofs were still common. ${ }^{311}$ However, the trend toward reform in the aftermath of fires was also apparent in Cologne. For example, the fire of the Jesuit School in 1727 was followed by a definite impulse toward renewal, particularly regarding the acquisition and care of fire extinguishers. ${ }^{312}$ Quantitative material about the Cologne fire ecology is scarce, doubtlessly due to the absence of a fire fund in the city until 1778 , when one was finally established by the archbishopric. A corresponding secular city fire fund was rejected sometime after 1815 by the Prussian government, and it was not until 1818 that the Bergisch Fire Insurance Company, headquartered in Düsseldorf, Germany expanded into the upper presidential district (Oberpräsidialbezirk) of Cologne. Indeed, it was the founding of private fire insurance companies (the Vaterländische of Elberfeld 1823, Aachener 1825, Kölner 1839-known as "Colonia" after 1841) that constituted the important developments in this regard during the nineteenth century. ${ }^{313}$ In early modernity, there was still a distinct lack of coherent technical expertise regarding the quantification of risk and fire losses.

As was generally the case elsewhere, city building ordinances were also of central significance for fire policey in Cologne- a fire ordinance proposal from 176o/61 (which was never enforced), for example, includes several relevant prescriptions in the first part of the document. ${ }^{314}$ However, all early modern regulations are relatively vague when compared with the intense precision of the Réglement pour les incendies de la ville de Cologne, enacted in 1801 in the then French occupied city. ${ }^{315}$ This document stipulated that chimney flues were to be built out of "bricks of the best kind," and that "the interior space of ordinary chimneys should measure 431 millimeters deep and 574 millimeters wide. Every flue should also protrude one meter over the roof. ... For those chimneys that must be swept with bristles, there should be at least 287 millimeters in the corners and in the interior space...." These and other specific architectural elements, accurate to the millimeter, could only be implemented after obtaining preliminary permission from the city —an "inspector of public building places" assessed these preliminary permits and granted final permission. ${ }^{316}$ These millimeter prescriptions clearly reflect the autosuggestion of revolutionary and

311 See the edict of July 21, 1610 against straw-roof construction in HStA Köln Edikte 6, Nr. 176.

312 HStA Köln V+V N 21, f. 6r-22v.

313 Hans Pohl, "Wirtschaftsgeschichte Kölns im 18. und beginnenden 19. Jahrhundert," in Zwei Jahrtausende Kölner Wirtschaft, ed. Hermann Kellenbenz, vol. 2: Vom 18. Jahrhundert bis zur Gegenwart, Cologne 1975, pp. 9-162, 111f. and Klara van Eyll, "Wirtschaftsgeschichte Kölns vom Beginn der Preussischen Zeit bis zur Reichsgründung," in Kellenbenz (ed.), ZweiJahrtausende, vol. 2, pp. 163-266.

314 HStA Köln V+V N 12, f. 1-13.

315 HStA Köln Edikte 6 Nr. 170 (1. Fructidor IX = August 19, 1801).

316 HStA Köln Edikte 6 Nr. 170 (1. Fructidor IX = August 19, 18o1). 
then Napoleonic rationalism imposed within the occupied territories - these regulations appeared only eight years after the establishment of the new measure of the "meter" through the National Convention, and two years after the determination of the value of the meter by Delambre and Méchain, embodied in the platinum prototype meter. ${ }^{317}$

The fact that these regulations did not actually lead to any kind of radical changes in architecture is not unique to Cologne. All in all, in comparison to other German cities, fire policey in Cologne can be characterized as absolutely exemplary for the Middle Ages - the precision of the fire ordinance of 1451 coupled with its large number of regulations is impressive. There was no comprehensive revision of it in early modernity, which on the one hand attests to its inherent strength, while on the other, to the fact that the impulses of administrative Enlightenment were almost wholly absent in Cologne. Beyond the rather sluggish implementation of the large "serpentine" fire hoses, the introduction of improved inspection techniques seems to be the single point of progress in the area of firefighting technology from about 1750 on. Thus, the impression that Peter Kissling formulated of the Upper German region is confirmed here too: the cities were initially the leaders of innovation, but later they definitely lagged behind the territories. ${ }^{318}$

In Cologne this lag can even be seen in the frequency of related policey regulations. During the main period of policey regulation activity (between 1568

317 Research on the French influence in the neighboring countries is large, cf. only Michael Rowe, From Reich to State: The Rhineland in the Revolutionary Age, Cambridge 2003; there is also a good tradition of studies on the history of internal French state statistics (Marie-Noëlle Bourguet, Déchiffrer la France: la statistique départementale à l'époque napoléonienne, Paris 1988) and certainly on the introduction of the metric system (cf. only Maurice Crosland, "The Congress on Definitive Metric Standards, 1798-1799: The First International Scientific Conference?", Isis 6o, 2 (1969), pp. 226-231). For Germany cf. Wolfgang von Hippel, "Von der Mühsal der Modernisierung-die Einführung des metrischen Systems in der linksrheinischen Pfalz", Aus südwestdeutscher Geschichte: FS Hans-Martin Maurer, ed. Wolfgang Schmierer et al., Stuttgart 1994, pp. 580-594, here 582 f.: it usually took quite a while to implement it, so this is an early example. Contributions to the political, social and economic history of the Rhineland tend often to take the metric system as an already established condition; for the relevant literature cf. Robert Mark Spaulding, "Changing Patterns of Rhine Commerce in the Era of French Hegemony, 1793-1813", Vierteljahrschrift für Sozial- und Wirtschaftsgeschichte 100, 4 (2013), pp. 413-431.

318 Peter Kissling, "Reichsstädtische und territoriale Policeyen. Ein Vergleich der Reichsstadt und der Grafschaft Kempten im 16. Jahrhundert," in Peter Blickle, Peter Kissling, and Heinrich Richard Schmidt (eds.), Gute Policey als Politik im 16. Jahrhundert. Die Entstehung des öffentlichen Raumes in Oberdeutschland, Frankfurt am Main 2003, pp. 229-83, here 231: “[...] Die erste Differenz zwischen Stadt und Stift besteht demnach in einem beinahe 2oojährigen Vorsprung der Stadt in der Gesetzgebungspraxis." 
and 1711) there were, on average, about 0.6 ordinances or council decrees per year regarding fires; the average for the entire time period of more or less continuous policey lawmaking (1437-1796) was 0.45 ; and in the late phase of the Old Reich (1711-96), the average was only o.39 - the intensity of regulation thus decreases substantially after $1711 .{ }^{319}$ Because of its favorable location, Cologne enjoyed access to and a full reception of western innovations such as the fire hose from the Netherlands. However, after the transition to what we are used to call early modernity, a rather leisurely pace reigned within the walls of Cologne. A relatively ample feeling of safety dominated - a feeling of safety that was never shaken by a great disaster. This is why Cologne serves as a good example of this type of large medieval imperial city - as do Augsburg, Nuremberg (last larger fire in 1130), and, at least for the time between the Thirty Years War (last fire in 1642) and the Napoleonic Wars (burning in 1809), Regensburg. Such cities initially entered modernity in a position of strength and, in comparison to smaller cities, they were less vulnerable to fire. Among the large imperial cities, only Frankfurt am Main experienced multiple large fires at the beginning of the eighteenth century. The others were mostly spared: they were relatively firesafe, but then stagnated and failed to innovate in the area of fire safety.

\subsubsection{The German Center of Security Innovations: Hamburg}

This was all quite different in the case of Hamburg, as I have illustrated in the earlier discussion of Hamburg's "fire ecology" (Ch. 3, 1.6). In Hamburg, the frequency of fires and the amount of fire losses were confirmed by the exact observation and documentation of contemporaries beginning in the seventeenth century: the city thus offers a singularly precise case study for Germany. There are surviving early Hamburg fire ordinance texts dating to $1462,{ }^{320}$ but they had no lasting effect to speak of. A series of printed fire ordinances first begins with the watchman and fire ordinances of $1626,{ }^{321}$ which formed the basis of the 1637 fire ordinance. ${ }^{322}$ Thus, Hamburg enters the scene of fire policey regulation almost three hundred years later than Cologne. According to the ordinance of 1637 (which inspired the preacher Edzard's parallelization of secular and spiritual fire

319 Statistics on the content analysis and thematic classification in Härter and Militzer, Repertorium.

320 HStA Hamburg Cl. viI Lit. La 1, vol. 1, Nr. 3c (note in Fe Nr. 2 vol. 2).

321 A handwritten "Fuer [sic] Ordenung," at the end of the sixteenth century in HStA Hamburg Cl. vir Lit. Fe Nr. 2, vol. 3, Nr. 10.

322 Heinrich Werner, Der Stadt Hamburgk Fewer-Ordnung/Wornach Dero Bürgere/ Einwohnere/Vnterthanen vnd jedermänniglich daselbst in begebenen Fewersnöthen sich richten vnd verhalten sollen, Hamburg 1637. 
ordinances ${ }^{323}$ ), various pieces of equipment should be kept with the "artillery" as well as in the parishes and with the captains of the city militia. Large water tanks should be placed in building yards, in limestone yards, and elsewhere. There should be annual inspections and citizens should have their chimneys cleaned every year. In case of fire, the three watchmen on the towers of the Cathedral, St. Nicolai, and St. Jacobi, should sound a storm warning-during the day, they should raise a red flag in the direction of the fire's location, and at night, a lantern. The firefighting work should be undertaken by all citizens under the leadership of court administrators, parish leaders, and artillery leaders. ${ }^{324}$

In this regard, the watchman ordinance, which divided the entire citizenry of Hamburg into five so-called Colonell districts (parishes) and into main teams, was relevant. ${ }^{325}$ After the fire of 1676 and the great fire of June 23, 1684, a revised version of the ordinance was issued, featuring only minor content changes. ${ }^{326}$ A new version was also issued in 1697 ; however, major changes were not implemented until the revision of Sept 10, 1750. The preparations for this reform date back to 1748 . The shock of the St. Michaelis fire (discussed above, in Ch. 3, 2), which led to the proliferation of disaster theology, also stimulated the ordinance reform. ${ }^{327}$ This new version of the watchman ordinance included many detailed stipulations that went beyond the spatial division of the city, such as precise instructions for dealing with fire in different circles of society; it also included extremely detailed instructions for firefighting in general and for keeping equipment operable. As a reaction to the St. Michaelis fire, it was suggested that the comparable Leipzig ordinances concerning watchmen on Leipzig's St. Nicholas church tower should be employed, ${ }^{328}$ and there were eight new paragraphs devoted to the handling of tower fires, as well

323 Cf. Ch. 3, 2, p. 113 .

324 Per parish: 100 buckets, 1 large and 1 small fire extinguisher, 6 buckets, 4 strong fire hooks, 2 large runners; also, the societies and fraternities should maintain the buckets and runners; the city captains should ensure that there are 50-10o buckets and 2 hand extinguishers available for each company.

325 Der Stadt Hamburg Wacht-und Feuer-Ordnung [...], Hamburg 1643 (HStA Hamburg Cl. vII Lit. Fe Nr. 2, vol. 3).

326 Der Stadt Hamburg Neu revidirte Feuer=Ordnung 1676; Der Stadt Hamburg Anno 1685. Neu Revidirte Feuer=Ordnung [...], Hamburg 1685 (HStA Hamburg Cl. vir Lit. Fe Nr. 2, vol. 3).

327 Cf. the first versions of the revision of 1748 and then, "Lit. B Zusätze zu der neuen FeuerOrdnung in Betracht der Thürme und Kirchen, welche derselben behüfigen Orten zu inseriren wären" (Lect. d. 26. Aug. 1750), HStA Hamburg Cl. viI. Lit. Fe Nr. 2, vol. 7, f. 42ff., here $141-46$.

328 Instructions from the Leipzig city council for the tower guard of St. Nicolai, Johann Luschküen, September 16, 1720 in the files of the fire ordinance revisions included in HStA Hamburg Cl. viI Lit. Fe Nr. 2, vol. 7, f. 165-69. 
as instructions for those responsible for church towers during thunderstorms. As in Ahlwardt's Bronto-Theologie, ${ }^{329}$ these tower watchmen were primarily responsible for the observation of thunderstorms and defending against their effects. ${ }^{330}$

However, the decisive change had already been implemented in Hamburgnamely the purchase and installation of large fire hoses. On December 12, 1677, Jan van der Heyden's famous fire hose was used for the first time in Hamburg. ${ }^{331}$ In 1720 , the restructuring was complete -25 city fire hoses were placed at fixed specific locations and, under the authority of the two head fire chiefs, the watchmen ordinance prescribed exactly how the fire watchmen should make their rounds in an exact order, leaving "fire signs" at specified points along their routes to document that they had done their work. ${ }^{332}$ Hamburg thus had greater affinity to the Dutch model-Amsterdam (and its environs) used an even greater number of large fire hoses. By the nineteenth century, Cologne still did not have as many large fire hoses as Hamburg had at the beginning of the eighteenth century. In 1748 Hamburg already had six ship-based fire hoses, located in the Alsterfleet, the kleine Alster, and two channels. ${ }^{333}$

As such, Hamburg was exemplary in the Holy Roman Empire. Hamburg also modeled Amsterdam's organization of fire prevention and firefighting, as established by Jan van der Heyden, earlier than Cologne; this was accomplished not only through purchasing fire hoses and by copying the fire-hose extinguishing ordinance in place since $1677,{ }^{334}$ but also through deploying officials to

329 Kittsteiner, Entstehung, pp. 74-79.

330 Neu-revidirte Feuer-Ordnung der Stadt Hamburg, Hamburg 1750 (HStA Hamburg Cl. viI Lit Fe Nr. 2, vol. 3, nr. 9): according to article 30 every church tower should provide a fire extinguisher, supplies of sheets, leather buckets, axes, as well as a vessel full of water. Cf. esp. article 38 , clearly dictated following the St. Michaelis fire, which prescribed careful inspection of roofs for fire during thunderstorms.

331 Johann Ehlert Bieber, Verzeichniss aller Feuersbrünste in Hamburg und der Umgegend, von 1281 bis 1830, Hamburg 1830, p. 10.

332 Twenty-four fire hoses are mentioned in HStA Hamburg Cl. viI, Lit. Fe, Nr. 3, vol. 3, fol. 2-6. 'Reglement der Hamburgischen Brandwachten' und 'Tabellen' jn welchen verzeichnet sind die gassen und Gänge, wo die von den 25 Stadt-Feuer-Sprützen genommene Brand-Wächter zu patrouilliren haben; wobey zugleich angezeiget die Corps de garde in welchem dieselbe ihre kupferne Brandwacht-Zeichen abgeben müssen" [1740] (HStA Hamburg Cl. vir Lit. Fe Nr. 2, vol. 7, nr. 2 u. 3). The number of twenty-five hoses remained constant until 1834 (HStA Hamburg Cl. viI Lit. Fe, Nr. 2, vol. 7, fol. 6-21; Nr. 3, vol. 20, nr. 5).

333 HStA Hamburg Cl. vir Lit. Fe Nr. 2, vol. 7, f. 68v.

334 "Entwurff Wie es in Amsterdam mit den bey den Sprützen benöthigten Arbeitsleuten gehalten wirdt. Ist Johan van der Heyden, Haubtman, und hat von allen Provincien die octroye, daß keiner die Schlangen-Brandt-Sprützen ihm nachzumachen oder auß den Lande zuführen sich unterstehn muß" (HStA Hamburg Cl. viı Lit. Fe Nr. 2, vol. 1b, n. 4). 
Amsterdam. ${ }^{335}$ In 1719 at the latest, an inspection trip to Amsterdam by Hamburg Fire Chief Thomas Simon Ammon is documented. ${ }^{336}$ While Hamburg went to Amsterdam for firefighting knowledge during the eighteenth century, surrounding territories looked to Hamburg. Friedrich Karl von Hardenberg, for example, requested Fire Chief Ammon's expertise in October 1733 for the royal government in Hanover, requesting that he dispense his knowledge in Hanover and Celle for a total of three weeks. Hamburg approved this request only reluctantly, because the absence of the local specialist was always a liability. ${ }^{337}$ Harburg also asked for Ammon's help in replicating Hamburg's firefighting techniques. ${ }^{338}$

In 1750, immediately after the lightning strike had destroyed St. Michael's church, the witty project maker Andreas Liedel was proposing a fire alarm clock to be positioned in each house and church, functionally similar to what is today used as fire and smoke detectors (Figure 58 and 59 ):

The machine was working like a clock with some gear wheels that would store enough tension for an alarm bell; through brass wires it was connected with different parts of the house supposed to conduct the eventual heat of a fire from all parts of the building to the machine where a release mechanism, hindered only by a portion of wax that would melt away by the heat conducted through the

335 An undated Ordnung der Schlangen Sprütze: Ambsterdam may have already originated in the time after the major fire of 1684 . It countains thirteen articles, of which the first five concern: Entwurff Wie es in Amsterdam mit den bey den Sprützen benöthigten Arbeitsleuten gehalten wirdt.

“1. Ist Johan van der Heyden, Haubtman, und hand [= hat] von allen Provincien die octroye, daß keiner die Schlangen-Brandt-Sprützen ihm nachzumachen oder auß den Lande zuführen sich unterstehn muß.

2. Hat daß Commando über 3 oo Mann, welche, wann ein Brandt entstehet, sich sofort an den Ohrte einfinden müßen.

3. Von diesen 300 Mann werden 50 zu rettung der jenigen Güther in deren Häußer der Brandt entstehet gebraucht, und müssen dieselbe einen eyd, daß sie die güther gehörigen Ohrtes restituiren wollen abstatten, auch das Wapen der Stadt auff den Armen und einen Lang roten Schleyer zum abziehen auffm Huet tragen.

4. Daß Hauß, in welchen der brandt außkömbt, wirdt von denen Bürgern in negster Capitain Hoff besetzet, damit nicht der gemeine Man so heuffig hinzulaufft und die arbeits Leute in ihrer arbeit verhindern, denen anverwandten aber so die Güther mit retten helffen wollen, wirdt ein sonderlich zeichen, welches die Capitains darzu haben gegeben.

5. Werden 50 beeydigte Zimmer und 50 Maurerleute die nichts alß was die högste Nottdurfft erfordert, herunterreisen mussen gehalten [...]." (HStA Hamburg Cl. vII Lit. Fe Nr. 2, vol. 1b, Nr. 4).

336 HStA Hamburg Cl. vir Lit. Fe Nr. 2, vol. 2, nr. $7 / 8$.

337 HStA Hamburg Cl. vir Lit. Fe Nr. 2, vol. 10.

338 HStA Hamburg Cl. viI Lit. Fe Nr. 15, vol. 8, fasc. 2 (1736-1738). 


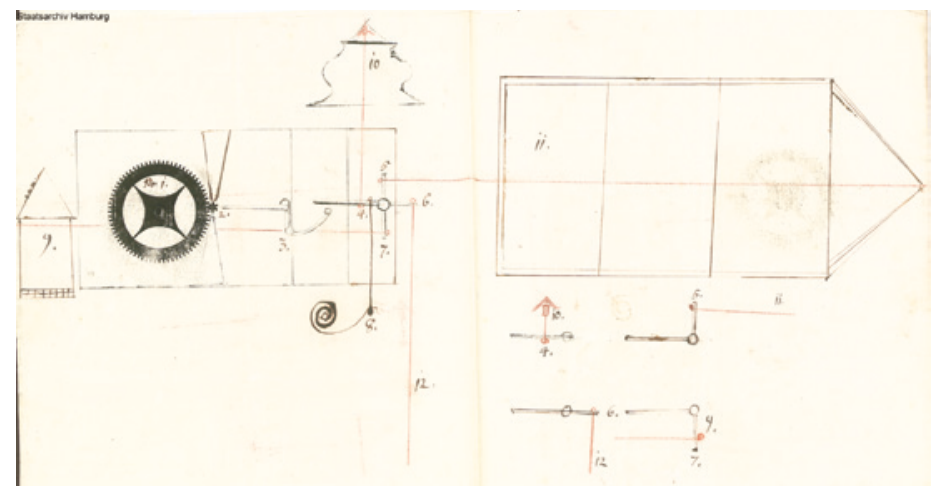

Staatsarchiv Hamburg

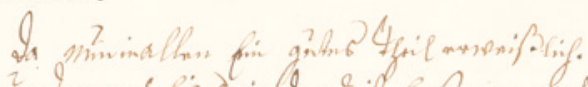

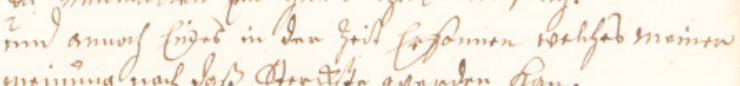

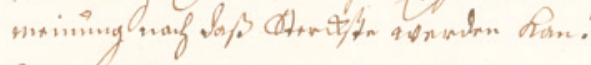

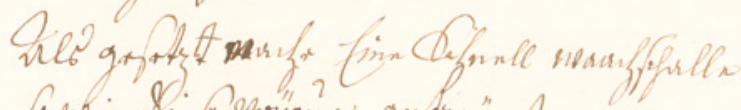

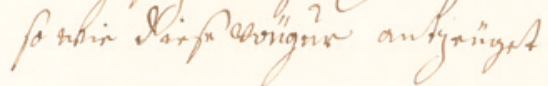

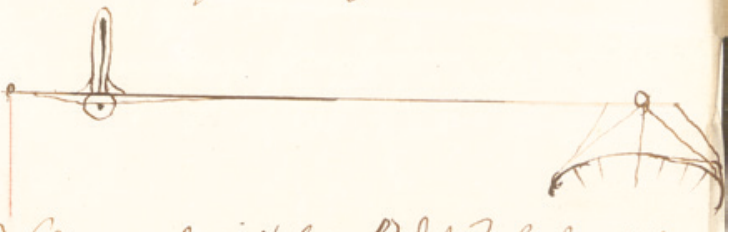

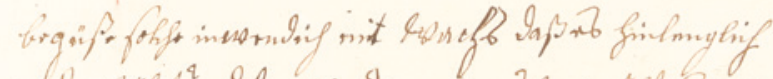

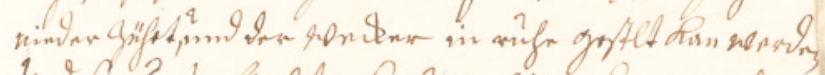

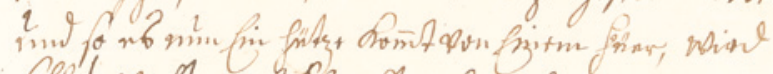

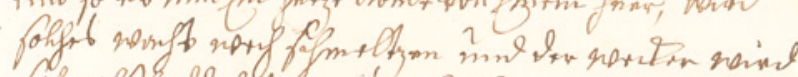
fii alfobole lop morian gin friner strobe

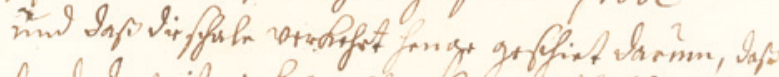

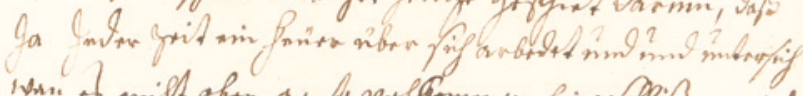

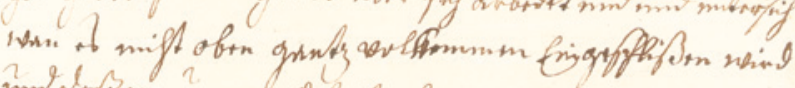

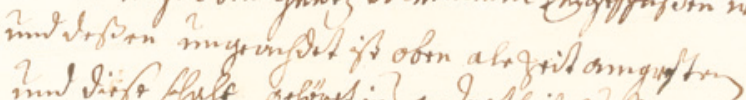

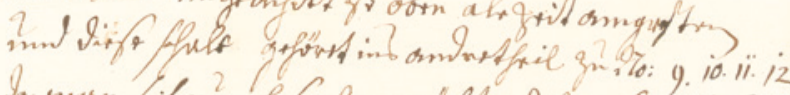

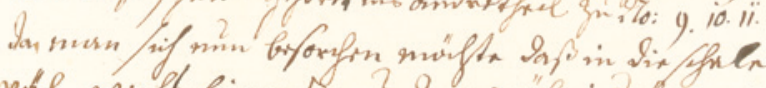

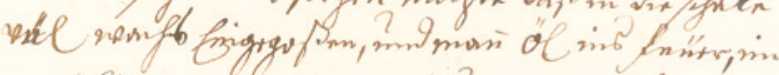

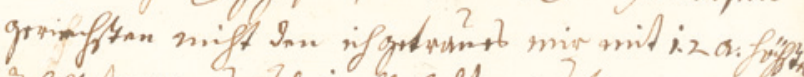

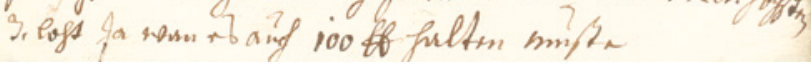

FIGURES 58 AND 59 Andreas Liedel explains to the magistrate of Hamburg by letter of May 1, 1750 his project for a Feuer-Wecker (fire alarm clock or detector) 
brass wires, would then enable an alarm signal, indicating immediately also the exact place in the building where the fire had broken out. Apparently, this was not yet ready for serial production and the proposition remained in the archives. ${ }^{339}$

Because there were constant increases in fire danger in Hamburg during the late eighteenth/early nineteenth century, there were calls for reform following every fire. While old fire policey techniques were still in use-such as mandates advocating caution from the city pulpits, as on Dec. $10,1802,{ }^{340}$ the most important intervention involved the interaction between city fire specialists (Fire surveyors [Brandschauer], head fire chiefs, fire fund deputies) and the Patriotic Society (Patriotische Gesellschaft), which with input from the city council, sought "scientific" avenues of reform and improvements in security production systems.

A main focus was the sector of early industrialization. For example, after a fire broke out in a tobacco factory (of the owner Flickwier) in 1793, general evaluations and a special fire policey ordinance proposal outlined the conditions warranting particular caution in tobacco factories. ${ }^{341}$ The Patriotic Society was also automatically engaged in such problems. Senator Johann Arnold Günther constructed the relevant proposals and asked the society to appoint experts to examine them; the discussion also extended to sugar refineries and other factories vulnerable to fire. His proposal was then published in the proceedings of the company and also in a separate format. ${ }^{342}$ Alderman Tonnies, the fire surveyor Ulrich Moller, Professor Brodhagen, the sugar factory owner J.F. Dunker, and the pharmacist Thorey participated in the review process and contributed to the development of a "theory of the prevention of fire risk." Peter Heinrich Christoph Brodhagen deemed all factories and manufacturing sites that he identified as "chemical industries" to be particularly vulnerable to fire-thus "laboratories, pharmacies, sugar works, lime kilns, dyeworks, breweries and spirit distilleries, metalworks of all kinds, but particularly those dealing with the smelting of metals, calico printing, tobacco factories, wool manufacturing,

339 HStA Hamburg Cl. vir Lit. Fe Nr. 2, vol. 13 .

340 Mandate due to increased instances of fire, Hamburg, December 10, 1802, HStA Hamburg Cl. viI, Lit. Fe Nr. 2, vol. 28a.

341 "Einen Hochedlen und Hochweisen Radh dieser Kayserlich freien Reichs Stadt unumgängliche Vorstellung und gehorsamste Bitte, abseiten Stielcke und Oberdorffer, Supplicanten. Zur Untersuchungs Sache wegen der bey Carl Siemon Flickwier am 8ten Januar dieses Jahres abends nach 10. Uhr ausgebrochenen Feuersbrunst” (HStA Hamburg Cl. VII, Lit. Fe Nr. 2, vol. 19, nr. 1); "Nothwendige Vorsichtigkeits Regel zur Verhütung von Feuers-Gefahr in Tobacks-Fabriken 1793. Febr." (HStA Hamburg Cl. viI, Lit. Fe Nr. 2, vol. 19, nr. 2, nr. 4).

342 Johann Arnold Günther, Ueber die anwendbarsten Vorschläge zur Verhütung von FeuersGefahr in Fabriken, und über die Gefahren von Selbst-Entzündungen, Hamburg 1797 (HStA Hamburg Cl. viI, Lit. Fe Nr. 2, vol. 19, nr. 5). 
ropemakers, leather tanneries, silk boilers." ${ }^{343}$ The proposals were sometimes quite unspectacular: tobacco factory workers, for example, were instructed not to smoke, to use specially protected lamps, and to unpack and transport tobacco only in the safety of natural light.

More interesting is the category of "spontaneous combustion," which included an extended overview of the inflammatory response of simple and composite materials, according to the then-current knowledge of chemistry ${ }^{344}$ - for example, "roasted, ground, and heated coffee" was thought to spontaneously combust in about half an hour. These reports were based on personal experience, but also on the observations of spontaneous combustion collected in journal and magazine reports that suggest that older theories of combustibility were still relevant in Hamburg: "According to chemistry, the basis of spontaneous combustion lies in substances of heat and light, which are dispersed in all bodies, and are released in one way or another, and which through the influx of respirable air the various mixtures of bodies often break out in violent flames. With mineral substances this combustion is due to decomposition; with vegetable and animal substances, it occurs when they are exposed to fermentation." ${ }^{345}$ Lavoisier's refutation of the Phlogiston theory was not yet widely known in Hamburg; in the context of practical questions of fire policey and careful storage, this fact, of course, made little difference. More significant here is the fact that academic chemistry was deemed relevant to practical considerations.

A proposal advocating "care for the rescue of movable possessions during sudden fire outbreaks" emphasized in a similar context of administrative/ semipublic discussions that during fires unauthorized persons often stole items from burning domiciles under the pretext of helping to save belongings. The proposed answer to this was to hire a troop of particularly competent persons supported by the fire funds, who would patrol the city in pairs, wearing a specific uniform. These people alone would be authorized to carry personal possessions out in case of fire. The proposal was discussed by the Patriotic Society and in the city government between 1791 and 1795; however, it was eventually implemented by a private enterprise: Georg Elert Bieber's Association Hamburgischer Einwohner zur Versicherung gegen Feuers-Gefahr (Association of Hamburg Residents for Insurance Against the Threat of Fire) employed $5^{\circ}$ rescuers, 5 supervisors, and 45 simple carriers who earned 4-6 Reichstaler per year as well as a certain compensation for each fire and for services rendered.

343 Günther, Ueber die anwendbarsten Vorschläge, p. $41 f$.

344 Phosphorus, fulminating gold, and pickling lime ignite in contact with air or water. A multitude of mixtures (iron filings with concentrated mineral acids, vitriol, nitric and hydrocloric acids with turpentine, etc.) are mentioned. 
Each rescuer had to wear a special bracelet at all times, which identified him accordingly in the event of a fire. ${ }^{346}$ In 1797 a black jacket and a cap with a flame painted on it were also introduced as the trademarks of a rescuer. ${ }^{347}$

In 1820 a comparable project was introduced: a squad of 36 "people rescuers" (Menschenretter) were employed to rescue people during fires. ${ }^{348}$ This project was clearly lifted from a Danzig provision of 1818 , the statutes of which were known in Hamburg. ${ }^{349}$ The rescuers were paid with funds from the General Fire Fund (General Feuer-Kasse) and were instructed to wear a black jacket and pants with white lacing and a badge on the left arm inscribed with the words "Feuer-Casse" (Fire Fund). Twelve of them were posted every evening at six strategic posts, equipped with a ladder, crowbar, lantern, winch, and rope. In case of fire, they were to concern themselves solely with "rescuing people, and nothing else," and this "without shying away from danger to themselves," until the point of obvious futility was reached. They were paid and otherwise rewarded for both their everyday service and for special efforts, and in case of injury or death, the rescuer or his survivors received a pension. "Only a man totally committed to the importance of the task of human rescue entrusted to him can be and remain a rescuer. Zeal for service, in addition to physical strength and ability, detached from lowly profit-seeking, are thus the essential conditions of retention." 350 Through some effort, this new service was made known to the city public. A civic culture supporting safety and security was inaugurated and widely advertised. ${ }^{351}$ However, since these rescuers often arrived late to fires, and since people were harmed in spite of them, this relatively expensive but short-lived endeavor was absolved in 1834 , following unsuccessful rescue attempts during three fires. ${ }^{352}$

Once again, the pervasive sensitivity in Hamburg concerning the increase in fire danger (statistically confirmed earlier in this study) clearly resonates in this context: "The frequent and saddening accidents occurring during the

346 Cf. "Instruction für die Retter der Brandversicherungs-Association" (HStA Hamburg Cl. VII, Lit. Fe Nr. 2, vol. 27, nr. 12).

347 HStA Hamburg Cl. viI, Lit. Fe Nr. 2, vol. 27, nr. 13.

348 Files in HStA Hamburg Cl. vir Lit. Fe Nr. 3, vol. 14.

349 HStA Hamburg Cl. vir Lit. Fe Nr. 3, vol. 14. Following the print attached to nr. 17: Statut des im Jahre 1818 gestifteten Vereins zur Rettung bei Feuers-Gefahr, Danzig 1819.

350 HStA Hamburg Cl. vir Lit. Fe Nr. 3 vol. 14, nr. 11a: "Instruction für die zur MenschenRettung bestimmten Retter," for exact wording, see HStA Hamburg Cl. viI Lit. Fe Nr. 3 vol. 14, nr. $11 b$.

$35^{1}$ "Bericht der General-Feuer-Cassen-Deputation über die zur Beförderung der MenschenRettung bey entstandenem Feuer zu treffenden Einrichtungen," Privilegirte wöchentliche gemeinnützige Nachrichten von und für Hamburg 126, Monday, May 29, 1820, 1-5.

HStA Hamburg Cl. vir Lit. Fe Nr. 3, vol. 20. 
fires occurring here in recent years, have, as is well known, engaged the general attention of the public, and it is not easy to have made many and diverse, albeit also often very premature, suggestions for remedies." ${ }^{353}$ This quote was written in a supplicating tone by the fire deputies Chateauneuf, Fersenfeldt, Sibertz, Nagel, Repsold and Wenke in 1835 when they suggested that these few paid rescuers ought to be replaced with a community of approximately 120 supervisors and 500-600 assistants coordinated by a few higher city authorities, who would be distributed across the entire city, creating a much denser network of potential rescuers. The notion of a volunteer fire department and of the cohesion of an active citizenry are clearly perceptible in the background here. However, this plan was rejected by the senate; instead, two reserve workers were posted at each of the 25 fire hose locations and equipped as people-rescuers, with the advantage being that everyone knew where to find them. The "many projects of artificial machineries, which would be brought from outside to the burning houses," were also rejected, because "one cannot not even send people there quickly, machines even less quickly." 354

Thus a long-lasting series of proposals of various types of "rescue machines" (Rettungsmaschinen) ended; models, which unfortunately no longer exist, were presented to the Patriotic Society. There were various proposals from Copenhagen and other cities concerning the possibility of improving or replacing traditional fire ladders in order to improve access to tall buildings. Johann Georg Repsold, who served as fire chief in 180o, deemed a hinge-like construction that would hook into a high-lying windowsill with a pulley construction especially worthy of support (Fig. 6o). ${ }^{355}$

According to Repsold, sixty such "machines" costing 25-30 Courant Marks each would have been necessary. This model was just as unsuccessful in gaining support as many other ladder models, however, it does document the existence of a constant discourse concerning projects and innovations intended to improve the methods and means of security production.

Repsold, as the resident expert, is simultaneously invoked as a major figure within the Hamburg security "laboratory". Repsold was a scientist serving as "head fire chief." While firefighting operations had generally been supervised by related professions - especially smiths and foundries within the fire policey administration, since they could also provide for the construction and maintenance of firefighting equipment-over the course of

353 HStA Hamburg Cl. viI Lit. Fe Nr. 3, vol. 20, nr. 11.

354 HStA Hamburg Cl. viI LIt. Fe Nr. 3, vol. 20, nr. 20.

355 Recommendation of Johann Georg Repsold of May 22, 1806, in HStA Hamburg Cl. viI Lit. Fe Nr. 2, vol. 28a, Nr. 45 . 


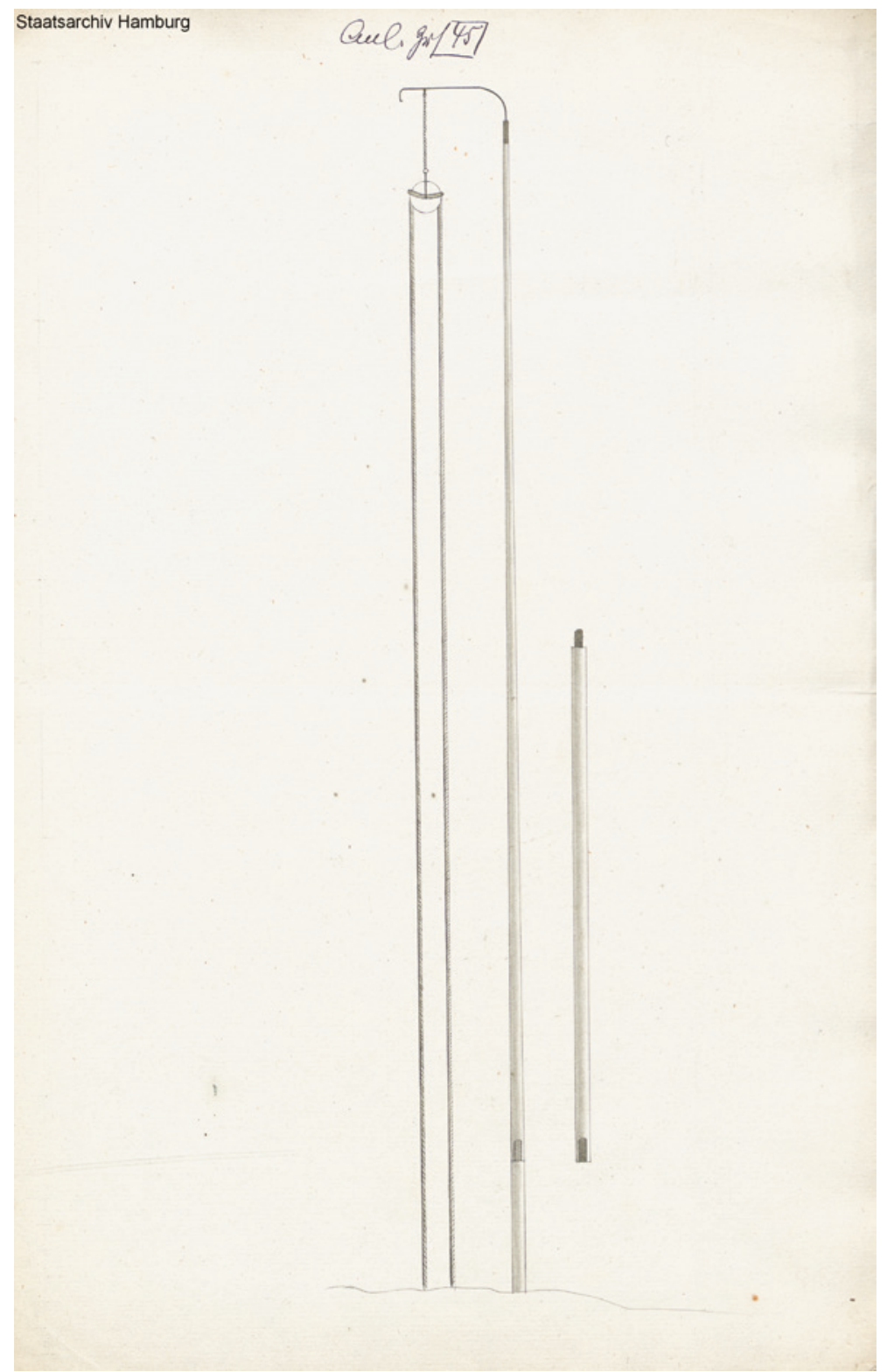

FIGURE 60 "Rescue machine" instead of ladders for high buildings, HStA Hamburg CL. VII Lit. Fe Nr. 2, vol. 28a, No. 5 Appendix

the eighteenth-century, a process of scientification and specialization of the profession evolved in Hamburg. The members of the Bieber family are one example of this; Johann Georg Repsold is another. He was not a simple, subordinate public servant; rather, he belonged to a circle of practical-scientific 
citizens. Repsold is perhaps better known today as the founder of the astronomical observatory in Hamburg, as a scientist and precision mechanic, who communicated with Fraunhofer and Gauß; ${ }^{356}$ but his main occupation was deputy fire chief, and, from 1808, head fire chief of the Hanseatic city, in which role he succumbed to a hero's death due to a falling beam during a firefighting operation in 1830. A statue erected in his honor still stands in front of the Museum of Hamburg History where the observatory was previously located. ${ }^{357}$ There are probably very few nineteenth-century firefighters who were honored with their own statue. He was given a complete state funeral with an entourage of one hundred carriages led by Mayors Bartels and Sillem, the syndic Sieveking, and the senators. Several pieces of verse devoted to the event, punctuating the early bourgeois culture of the time, appeared in the newspapers: in the Hamburger Nachrichten of January 30, 1830, Theodor Körners's "Auf dem Schlachtfelde von Aspern-1812" (On the battle field of Aspern-1812") was quoted: Repsold had died for the fatherland. ${ }^{358}$ Two weeks earlier, a poem devoted to the hero, actually entitled "Repsold," had appeared in the same newspaper.

Only he, the bold rescuer in danger

The protection in the time of need, never to return again!

No cry for help will wake him! Now and forever

His shattered head fell to the earth!

356 Jürgen W. Koch, Der Hamburger Spritzenmeister und Mechaniker Johann Georg Repsold (1770-1830), ein Beispiel für die Feinmechanik im norddeutschen Raum zu Beginn des 19. Jahrhunderts (Hamburg: 2001).

357 "Eine Skizze des Denkmals in Skizze des Denkmals für Joh. Georg Repsold 183o" (StAH Best. 622-1 Repsold 7); One might take this as a starting point of patriotic nationalizing the heroic deeds of firemen, cf. today the commemoration statues and monuments built for the 347 firemen killed while fighting the fire and rescuing the remaining people in the World Trade Towers on September 11, 2001: Zipporah Lax Yamamoto: After $9 /$ 11: Transformations of Memory into History. Diss. UCLA 2011; Cornel Zwierlein, "Vom Londoner Brand 1666 bis 9/11. Feuergefahr und Feuerexperten seit dem 17. Jahrhundert," Geschichte in Wissenschaft und Unterricht 67, 11/12 (2016), pp. 711-730.

$35^{8}$ "D'rum soll es die Nachwelt laut erfahren, \| Wie auch Deutsche Bürger dankbar waren, II Wie wir der Gefallenen That erkannt, || Daß ihr Tod uns Lebende ermuthet, || Daß sie für Unwürd'ge nicht geblutet, \\ Das beweise, Deutsches Vaterland!- \\ Deine Sänger laß in Liedern stürmen, \ Und zum Steine füge kühn den Stein \ Und die Pyramide laß sich thürmen \\ Der gefallnen Brüder werth zu seyn." (according to a transcription in StA Hamburg best. 622-1 Nachlass Repsold, S. 9). For further literature on early nineteenth century firefighting Zwierlein, "Vom Londoner Brand 1666"; for the Berlin fire department cf. Olaf Briese, Für des Staates Sicherheit. Das Löschwesen im 19. Jahrhundert und die Gründung der ersten Berufsfeuerwehr Deutschlands in Berlin 1851, Berlin 2018. 
His eye will never look up again, calculating,

To force, from the freely chosen paths of terror,

The wild run of increasing doom

Into its more bounded limits. ${ }^{359}$

In stark contrast to the old imperial city of Cologne (the largest German city until 160o), Hamburg demonstrated a much more advanced development in the theory and practice of security production in terms of fire safety from the seventeenth century onwards. This is not only exemplified by the existence of the General Fire Fund (see below Ch. 4, 1.2), but also in terms of fire policey, which was no longer limited to counting buckets and ladders, but fully integrated within the discourse of the popular Enlightenment. ${ }^{360} \mathrm{Ham}-$ burg was home to the first Enlightenment society in Germany definitively oriented toward practical, economic improvement- the Hamburg Society for the Promotion of Arts and Useful Industries (Hamburgische Gesellschaft zur Beförderung der Künste und nützlichen Gewerbe), also known as the Patriotic Society, was founded in 1765 . The society served as a context for expert dialogues between the senate, aldermen, and fire chiefs-projects were started there, and everything was carefully evaluated by experts like Repsold. In the formative phase of the late Enlightenment, the scientification and specialization of this area was an elementary part of the process of transformation within society: the production of security became a state function, shaped for the benefit of all citizens by a few exemplary researcher-citizens. The ways in which the specific Enlightenment world of Hamburg was intertwined with national Enlightenment discourse will be further explored in section 2 of this chapter. Among other major cities assuming a leadership role during the seventeenth century for old Rhenish and southern German imperial cities - the "winners" in terms of population growth and importance-none played as important a role as Hamburg, even in supraregional terms, as a laboratory for the mechanisms of security production. In the major territorial capitals of the empire-Berlin, Dresden, Munich - the primary stimulus for potential changes typically originated at the state level, rather than emerging from independent circles of the local elite. Concerning the territorial system of fire policey and security production, Prussia offers the best third paradigmatic case study.

359 StA Hamburg best. 622-1 Nachlass Repsold, p. 10.

360 On this see Franklin Kopitzsch, Grundzüge einer Sozialgeschichte der Aufklärung in Hamburg und Altona, 2 vol. (Hamburg: 1982). 
The State's "Images" of the City Collective: An Approach to Disaster Memory and to Learning from Disaster (e.g., Prussia)

Since most territorial cities were ruled by a superordinate authority at the territorial level, as was the case in Prussia, Saxony, Hanover, and other regions, focusing on the territorial administration yields the most relevant insights into the development of security production mechanisms in these small territorial cities. In the "Kurmark," the Prussian central province, the supreme authority was the Prussian General Directorate, established in 1723, which operated as the central decision-making body regarding all provincial management issues - including fire policey and fire insurance societies. While these administrative bodies were directly managed by the Chambers of War and Domains (CWD; Kriegs- und Domänenkammern), the General Directorate made all final decisions. There were distinctions made between Kurmark and Neumark cities, between the rural areas (plattes Land), and Berlin-which because of its special importance was not subordinate to rule by the Kurmark CWD. The fire regulations for the royal residence cities of Berlin, Cölln, and Friedrichswerder took precedence over other cities and were later deemed exemplary. ${ }^{361}$ In particularly urgent matters, the General Directorate could attend to a case directly-thus, for example, the reconstruction of Neuruppin after the fire of 1787 and that of Zehdenick after the fire of 1801 were facilitated directly by the highest authorities rather than funneled through the CWD. ${ }^{362}$ Above all, the General Directorate dealt with questions concerning decrees of edicts and ordinances in the cities and in rural areas - thus with fire ordinances in particular ${ }^{363}$ _ but it was also responsible for final approval of larger fire equipment acquisitions and for the supervision of provincial fire societies.

The CWD in Kurmark and Neumark had the oversight to regulate all fire policey measures. In rural areas, i.e. in the villages, this was basically managed

361 Christian Otto Mylius (ed.), Corpus constitutionum Marchicarum oder Königlich preußische und churfürstlich Brandenburgische in der Chur-und Mark Brandenburg, auch incorporirten Landen publicirte und ergangene Ordnungen, edicta, mandata, rescripta, Teil 1-6, nebst Anhang und Continuatio 1-4, Berlin 1737-55, V, I, II, Nr. 3, col. 143-56: fire ordinance July 15, 1672 for Berlin and Cölln; no. 4, col. 155-68: fire ordinance Novemer 8, 1672 for Friedrichswerder; no. 7, col. 169-72 fire ordinance January 26, 1701 for the rural areas (plattes Land); no. 13, col. 191-214: revised fire ordinance 3 May 1707 for Berlin and its suburbs.

362 GStAPK Berlin HA II, Abt. 14, tit. ClXIV Stadt Ruppin und tit. cxc Stadt Zehdenick.

363 Cf. approbation files for the fire ordinances of the cities of Frankfurt an der Oder, Rathenow, Brandenburg, Potsdam, Beelitz, Trebbin, Werder, Liebenwalde, Teltow, Zossen, Saarmund, the Prignitz cities, Büsenthal, Bernau, Köpenick, Havelberg, Liebenwalde, Mittenwalde, Müncheberg, Oderberg, Oranienburg, Strausberg, Zinna and other Kurmark cities (GStAPK Berlin HA II, Abt. 14, tit. CCXVII, Nr. 7, 8, 11-17, 2O-22, 29, 31, 33). 
by the district administration (Domänenamt). In the cities, fire policey was managed, in principle, by the city magistrates themselves, regardless of whether it concerned mediate or immediate cities (Mediatstädte or Immediatstäd$t e)$ : mediate cities were subordinate to one Domänenamt while immediate cities were subordinate only to the CWD. But the Chamber of War and Domains always prescribed the framework of rules and ordinances and exercised overall control-always subject, of course, to the General Directorate. In reality, therefore, the cities adopted laws and ordinances that were imposed or validated by the central authorities, and which always required approval.

Previously, individual cities still had the authority to enact small, unsophisticated fire ordinances - an example being the fire ordinance of 1716 from the small town of Lenzen, which was forcefully imposed on all citizens. ${ }^{364}$ However, in 1718 the Berlin government imposed a collective fire ordinance on all Kurmark cities, which then became exemplary for many other Prussian provinces, perhaps, in part, because it was recorded in the ordinance compilations by Christian Otto Mylius. ${ }^{365}$ This fire ordinance was then widely distributed through administrative channels: around 1719, Steuerrat (commissioner) Lütkens of the Uckermark and Niederbarnim district forwarded 450 copies of the new fire ordinance to the magistrate of Strasburg — almost every single homeowner must have been thereby provisioned. ${ }^{366}$

Fire inspectors were sent to inspect individual cities and were instructed to pay attention to: barns still standing in the city, remaining wood and straw roofs, as well as other architectural entities; the existence and quantity of highly flammable material (gunpowder, pitch, tar) in the houses; whether the fire extinguishers were in good condition and were stored in a publically accessible manner; whether every homeowner also possessed a copy of the city fire ordinance and whether an excerpt thereof was also posted in the home. ${ }^{367}$ The inspection reports provide an overview of the entire scope of the territorial firefighting system: in 1723 it was determined that 34 large wheeled fire hoses, 88 simple hand sprayers, 2290 leather buckets, 122 fire hooks, and 194 fire ladders were required to fully equip 46 administrative areas; 368 however, in 1742/ 43 it was found that there were hardly any large fire hoses in the territories at all. In 1756 a general overview was created, the Extract from those received

\footnotetext{
364 "Revidirte Feuer-Ordnung Der Stadt Lentzen, Stendal [s.d., 1716]" (BLHA Potsdam Rep 8 Lenzen 4oA, unfol.).

365 "Allgemeine Feuer-Ordnung in denen Städten der Chur-Marck," Berlin, November 1, 1718, Mylius, Corpus constitutionum Marchicarum v, I, II, Nr. 28, Sp. 241-46.

366 BLHA Potsdam Rep. 8 Strasburg 829 (July 20, 1719).

367 BLHA Potsdam Rep. 2 D 721, f. 62r-63v.

368 BLHA Potsdam D 68o, f. 21v-23r.
} 
reports and negotiated fire-instrument acts, what fire-instruments exist among all Kurmark districts and related outpost farms, and what must still necessarily be acquired (Extract aus denen eingekommenen Berichten und verhandelten FeuerJnstrumenten-Acten, was an Feuer-Jnstrumenten auf sämtlichen Churmärckh. Aemtern und denen dazu gehörigen Vorwerkern vorhanden, und was an dergleichen noch nothwendig anzuschaffen nöthig ist). This document covered 64 administrative districts and listed the following equipment as either existing or still needed (the latter figure in parentheses): 32 (81) large serpentine hoses, 86 (268) "Wasser-Thienen" (i.e., water tanks for the hoses), 663 (612) small sprayers, 659 (122) hooks, 823 (94) ladders, and 1370 (832) leather buckets. ${ }^{369}$

In general, the diffusion of large fire hoses in the territories and rural areas was very slow and halting. Including ship-based hoses, the city of Hamburg had as many or more large hoses than the entire Kurmark area at this point. As late as 1783 it was noted that "the fire hoses in the territorial cities are extremely inadequate, which basically means that they are equipped only with turning pipes but not with hoses." ${ }^{370}$ Nevertheless there was obviously some progress made during the reign of Friedrich II. Quantitatively, an overview by the Kurmark authorities investigating the existing fire hoses in the territorial cities and associated villages, which began on August 4, 1789 and ended in 1795, demonstrates a distinct difference from 1756: among the 59 administrative districts that submitted information, covering 585 outposts and villages, $25^{2}$ existing fire hoses were reported and an additional 145 were listed as needed. ${ }^{371}$ But even so, there was often only one large fire hose per area, or sometimes none at all, and many villages shared a single one, which, in case of fire, was difficult to transport: "The lack of fire hoses is often a cause of the size and increase of a fire, so that even when a fire hose is brought from a neighboring region to help only hours after a fire has started, it no longer has its intended effect. It would therefore be very good if every village, outpost, and colony, could have its own fire hose." This passage was written by the Beeskow watchmaker Johann Christian Lube in 1806, who submitted a model and description of a fire hose to the Kurmark CWD. In his opinion, it was an inexpensive alternative since it could be built in stages used many common parts, thus cutting costs. The project was however skeptically and immediately rejected. ${ }^{372}$ Another proposal in 1743 from the third mayor of Salzwedel, Jacob Friedrich Annisius, to replace the mostly wooden

\footnotetext{
369 BLHA Potsdam D 680, f. 21v-23r.

370 Blha Potsdam Rep. 2 D 721, f. 93r (Chamber of War and Domains [Kriegs- und Domänenkammern; hereafter CWD ], Berlin, November 26, 1783 - to Old March [Altmark]Prignitz Deputation).

371 BLHA Potsdam Rep. 2 D 686, f. 77r-84r.

372 Lube an die KDK, Beeskow 4.10.1806, BLHA Potsdam, Rep. 2 D 706.
} 
chimneys with stone seemed like a more long-term solution, but there was also no discussion of any widespread implementation of this plan. ${ }^{373}$ The forester Hartmann was obviously more successful with his pro memoria, which he submitted directly to the General Directorate: he proposed a new ladder, based on the simple idea that through creating a means of connecting multiple ladders, one could construct appropriately long ladders out of inexpensive wood from common trees, instead of relying only on expensive "split tall fir trees." This successfully persuaded the evaluating authorities and the General Directorate forwarded the concept and a sample drawing to the CWD with instructions to use these new connectable ladders for any new or replacement acquisitions (Fig. 61). ${ }^{374}$

These examples notwithstanding, there are significantly fewer projects and reform proposals in the CWD and General Directorate files than there are in Hamburg. Furthermore, the projects that are documented are targeted less at novel technical, chemical, or logistical-organizational innovations than at ways to reduce costs and improve the deployment of large quantities of firefighting equipment. The primary energies were clearly directed toward attaining a uniform basic level in all places, on widespread coverage and penetration into all areas. In some sense, comparing Prussia to Hamburg or other large western European cities as innovation centers is like comparing China of the 199os to the West: there were cheap imitations in great quantity instead of original inventions. However, this was itself a highly important, even decisive, contribution to the development and distribution of the new order of security viewed as a whole; had they remained limited to Amsterdam, they would have failed to create much of an impact. After all, a developmental biotope or laboratory of modern security innovations would always remain historically marginal were it not for widespread diffusion.

Another unusual feature unique to Prussia, at least in its central provinces, in the context of eighteenth-century central Europe, is the way in which city reconstruction was organized after a disaster-especially after a fire disaster. In Prussia, reconstruction always served as a means to improve the technology of security. However, in contrast to most territories at this time, reconstruction was always directed by central authorities. Indeed, as the following examples indicate, this trend started much earlier than the date of 1855 reported in the literature. ${ }^{375}$ On August 2, 1708, after the fire of the Prussian town of Crossen, King Friedrich I issued a reconstruction order ${ }^{376}$ that became an exemplary

373 BLHA Potsdam Rep. 2 D 721, f. 1r-27v.

374 BLHA Potsdam Rep. 2 D 721, f. 121a,b, GD to CWD 29.11.1786.

375 Spohn, "Der Stadtbrand als Chance", p. 52.

376 Mylius, Corpus constitutionum Marchicarum, V, I, II, Nr. 16: "Verordnung, wegen Wiederaufbauung der abgebrandten Stadt Crossen, und wie es damit gehalten werden soll" (August 2, 1708). 


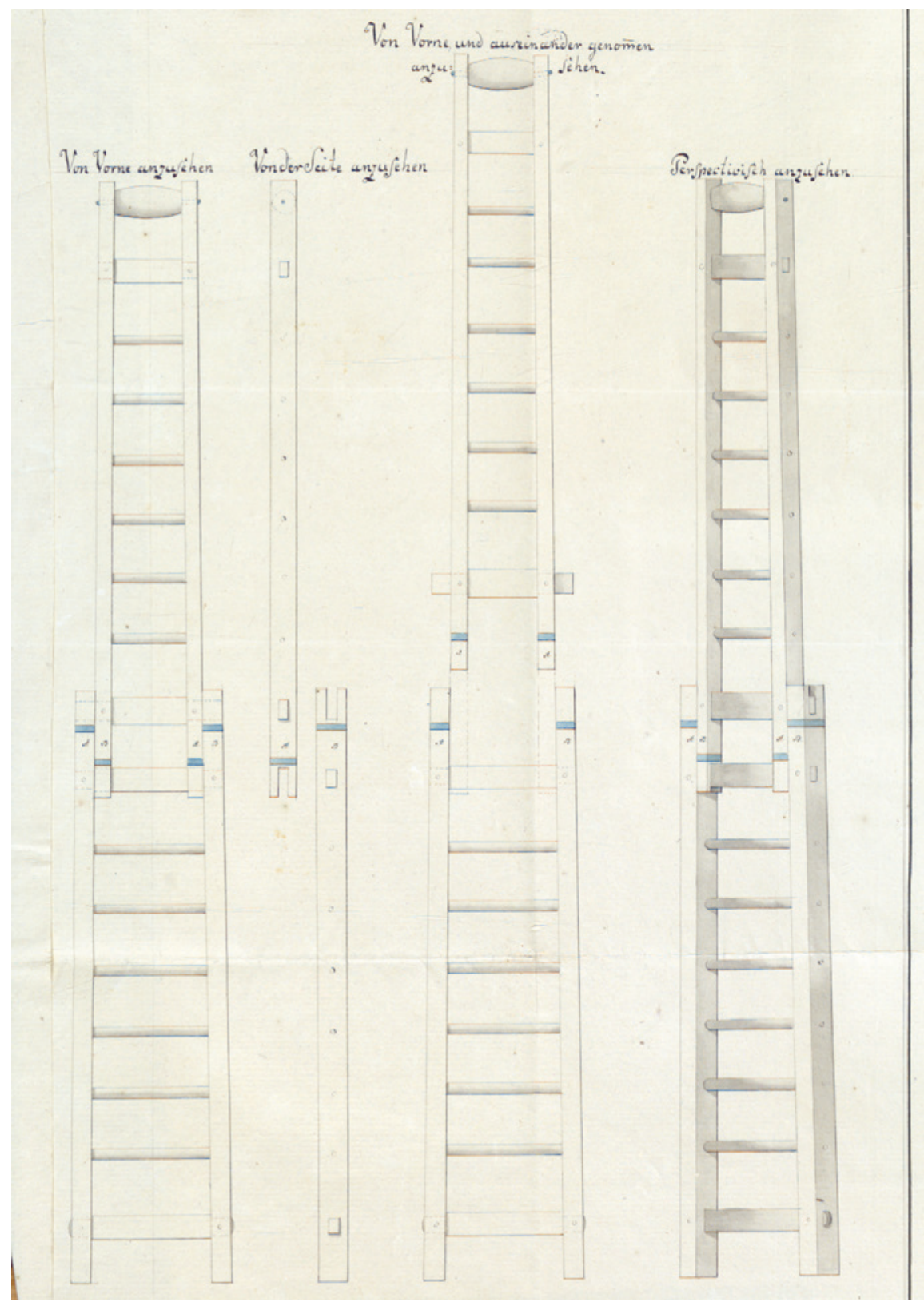

FIGURE 61 Connectable ladder system proposed by the forester Hartmann 1786, B LHA Potsdam Rep. 2 D 721, f. 121b 
model for city reconstruction operations in the eighteenth century.377 While the reconstruction of Cottbus after the fire of 1671 was relatively chaotic and dragged into the 1730 s, ${ }^{378}$ by the eighteenth century, at least after the Luckenwalde reconstruction of 1723 , the reconstruction process invariably followed the pattern of a 15-point process, which was also presumably applied earlier during the 1708 reconstruction of Crossen. ${ }^{379}$ This process was clearly employed in the reconstruction of Templin after the fire of August 24, 1735, 380 in Neuruppin after the fire of August $1787,{ }^{381}$ in Zehdenick after the fire of the May 27, 1801, 382 and certainly also in a majority of Wesphalian cities studied by Thomas Spohn, to the extent that they were already Prussian in the eighteenth century. ${ }^{383}$

These centrally organized reconstruction activities patterned themselves after the ideal city planning notions of the Renaissance, still popular at the time, ${ }^{384}$ which involved the idea of designing cities according to aerial perspective maps on a drawing board and then imposing them en bloc onto the landscape. ${ }^{385}$ Beginning in the sixteenth century there are several examples of

377 On this topic, see Reinisch, Der Wiederaufbau der Stadt Neuruppin; Ralph Jaeckel, '... daß so wohl der Regularität nach, und zum Zierath der Strassen, als vor Feuers-Gefahr sicher gebauet werde ... '-Die Erneuerung der Städte in Brandenburg-Preußen im Zeitalter des Absolutismus zwischen 1640 und 1806/11. Untersuchungen zu den städtebaulichen Retablissements und Etablissements in Städten der südlichen und östlichen Kurmark sowie der Neumark Brandenburg, PhD thesis, Humboldt University Berlin 1999; Christof Baier, Bürgerhäuser in Templin und Zehdenick. Die Theorie vom bürgerlichen Wohnhaus und die Praxis des provinzialstädtischen Bürgerhausbaus in Brandenburg-Preußen im 18. Jahrhundert, PhD thesis, Humboldt University Berlin 2006.

378 Jaeckel, "Erneuerung," pp. 436-466.

379 On the reconstruction of Crossen, see Jaeckel, "Erneuerung," pp. 466-507.

380 Baier, Bürgerhäuser, pp. 61-88.

381 Reinisch, Wiederaufbau.

382 Baier, Bürgerhäuser, pp. 153-83, the reconstruction regulations appeared in print in 1802 and are reproduced in Jaeckel, "Erneuerung," appendix 2.4.

383 Spohn, "Stadtbrand als Chance"; Thomas Spohn, "Sollen recht ordentlich bauen," Der Märker 39 (199o), pp. 191-206, 250-61.

384 On this Hanno-Walter Kruft, Städte in Utopia. Die Idealstadt vom 15. bis zum 18. Jahrhundert zwischen Staatsutopie und Wirklichkeit, Munich 1989; Eva-Maria Seng, Stadt-Idee und Planung. Neue Ansätze im Städtebau des 16. und 17. Jahrhunderts, Munich 2003; Kersten Krüger, "Die Idealstadt der frühen Neuzeit, insbesondere in Nordeuropa," in Frank Braun (ed.), Städtesystem und Urbanisierung im Ostseeraum in der frühen Neuzeit. Wirtschaft, Baukultur und historische Informationssysteme, Münster 2004, pp. 11-47; City planning and city concepts even beyond the more narrow focus of architectural history are treated in Élisabeth Crouzet-Pavan, Denis Crouzet, and Philippe Desan (eds.), Cités humanistes, cités politiques: 1400-160o, Paris 2014.

385 There is discussion about whether cities in the Middle Ages were already conceived according to a "plan" — for example, the cities founded by the House of Zähringen, for which a 
this implementation in Europe, but many more are to be found in overseas colonies. In Europe, these visions of urban design were primarily realized only in the new construction of fortress cities. Typically, during the reconstruction of even totally destroyed major cities, the inhabitants demanded reconstruction according to the precise boundaries of their properties; this led to cities typically being rebuilt without any major changes in road and parcel layout. For this reason, the grid-layout planned city was fully realized mostly only in the colonial arena. ${ }^{386}$ Although Brandenburg attempts to found their own oversea colonies had limited significance during this time (the Africa-Compagnie), ${ }^{387}$ a different, inwardly directed idea of colonization became increasingly important in Brandenburg-Prussia from the second half of the seventeenth century on. The settlement of Huguenot and Salzburg religious refugees resulted in "colonies;" and as David Blackbourn has vividly recounted, ${ }^{388}$ certain land reclamation projects, such as the draining of the wetlands surrounding the Oder and Warta rivers, instigated settlement policies that operated explicitly as policies of colonization.

The administrative terminology in Prussia, which constantly refers to "Retablissement" or "Melioration," demonstrates that the influence of French absolutism-imported perhaps by the French Huguenot immigrants - was also at play here. By the late sixteenth/early seventeenth century, the mélioration of the state and the empire was counted among the primary tasks and duties of the French king. In a text called L'Horoscope du Roy, which was composed around 1622 and describes the future and the duties of Louis XIII, François Goujon of Lyon included under the concept "mélioration" the king's duty "to

rudimentary compass technique was probably employed in the planning. See Klaus Humpert and Martin Schenk, Entdeckung der mittelalterlichen Stadtplanung. Das Ende vom Mythos der "gewachsenen Stadt", Stuttgart 20o1; the history of architecture has always traditionally maintained, in contrast, that for early cities there is no evidence whatsoever of any plan in written form, other than certain exceptions such as the St. Gallen convent plan; cf. Günther Binding, Susanne Linscheid-Burdich, and Julia Wippermann, Planen und Bauen im frühen und hohen Mittelalter nach den Schriftquellen bis 1250, Darmstadt 2002. It is undisputed that in terms of the city planned along a grid from an aerial viewpoint, the abundance of city planning utopias of the Renaissance are something qualitatively very different.

386 Cf. Robert Home, Of Planting and Planning: The Making of British Colonial Cities, London 1997, who analyzes the idea and practice of city planning throughout the emerging British Empire beginning with the Plantation of Ulster (Londonderry, Nordirland 1622). Cf. Jay Kinsbruner, The Colonial Spanish-American City: Urban Life in the Age of Atlantic Capitalism, Austin 2005 .

387 Well-known is the Brandenburgisch-Afrikanische Compagnie attempt of 1682 .

388 David Blackbourn, The Conquest of Nature: Water, Landscape and the Making of Modern Germany, London 2006. 
restore what weather and bad fortunes have destroyed [decreased]." 389 Repair and recovery after accident-based destruction is precisely what the Prussian administration systematically implemented. Regarding French colonies, Vauban wrote a famous opinion in 1699 that employed the concept of "rétablissement", the Moien de retablir nos colonnies de l'Amérique \& de les accroistre en peu de temps. ${ }^{390}$ "Rétablissement" and "melioration" are thus the French equivalents of that what was called "improvement" within English interior and colonial development and reform politics. ${ }^{391}$

This is not the place to take up the multifaceted discussion of absolutism beginning with this aspect of reform politics. ${ }^{392}$ While it is unclear how one should understand the impulses of centralizing government, of its achievement, or lack thereof, due to resistance by estates, nobles, juridical, or clerical counterbalancing powers, a decisive point is found in the new epistemic framework of early modern ("absolutist") governance, characterized by the methodization of empiricism, reflexivity, and long-term planning located within the interplay between rulers and advisors. ${ }^{393}$ It is precisely this "long-term planning" - within the overall empiricist aim of shaping the world and its future - that functioned in Prussia as the "Retablissement" and the "Melioration" of territories and cities, which appeared there in the purest possible form within the obviously limited context of early modern realities. Of course, there is always deviation between the vision for and the actual realization of a project; nonetheless the attempt and aspiration, the basic positioning and reflexive "aiming toward" in decisionmaking processes and long-term management are of great significance. How then was building safety integrated into concrete cases of reconstruction?

Ralph Jaeckel compared the Crossen regulations with the reconstruction practices in the Kurmark and from that he distilled a 15-point plan comprising the common Prussian administrative system of the eighteenth century. This 15-point plan demonstrates the impressively standardized manner in which a bureaucratic routine for the planning and realization of a unified idealized city was established:

389 Qtd. Yann Lignereux, Lyon et le roi. De la ,bonne ville' à l'absolutisme municipal (1594-1654), Seyssel 2003, pp. 540-42.

390 On this see Michèle Virol, Vauban. De la gloire du roi au service de l'état, Seyssel 2003, pp. $175^{-79}$.

391 Cf. J.H. Elliott, Empires of the Atlantic World. Britain and Spain in America 1492-1830, New Haven 2006, pp. 88-97; Richard Drayton, Nature's Government: Science, Imperial Britain, and the "Improvement" of the World, New Haven 2000.

392 See the overviews of Lothar Schilling (ed.), Der Absolutismus-ein unersetzliches Forschungskonzept?, Munich 2008 and Dagmar Freist, Absolutismus, Darmstadt 2008.

393 Zwierlein, Discorso und Lex Dei, pp. 25ff., 298f., 310-13. 
1. Report of the commissarius loci/Steuerrat responsible for the area to the CWD including a list of victims, damage estimation, information about causes of the fire, etc.

2. Determination of the legitimate claims to payments from the fire insurance funds according to the number of insured houses burnt down, and determination of the financial circumstances of the affected citizens.

3. Creation of temporary shelters for the victims (wooden huts in front of the city gates).

4. Negotiations on the granting of state/direct royal support funds and reductions (freedom to build funds [Baufreiheitsgelder], beneficia)

5. Preparation of a reconstruction plan by the district's building inspector according to the general specifications for fire-resistant buildings of the whole territory.

a) Conception and justifications for major changes, rough planning of the construction processes. ${ }^{394}$

b) Situation map of the area with damaged areas marked in red in contrast to the undamaged building stock marked in black, planned regulatory measures (according to the Kurmark construction regulations of July 26, 1741) sketched in with red lines.

6. Approval of the reconstruction plan by the building department, the CWD, and the General Directorate.

7. Begin concrete planning, in particular the establishment of plans for the construction of residential buildings according to appropriate types for different social classes (houses for craftsmen, traders, beer and brandy brewers, farmers, middle and upper-class burghers, cottage inhabitants, etc.)

8. Negotiations with contractors and craftsmen.

9. Negotiations for the procurement of construction materials.

10. Direction of the construction processes by the responsible building inspector, periodically through the commissarius loci/Steuerrat; periodic reporting to the General Directorate and the CWD.

11. After rebuilding the homes, reconstruction of public and religious buildings.

12. Revision and acceptance of the reconstruction by the chamber's construction department council.

13. Final improvements, correction of defects.

14. If necessary, report on punishment of those who caused the fire.

394 A corresponding tabular reconstruction plan for Luckenwalde 1723 is reproduced in Jaeckel, "Erneuerung," Fig. 68. 
15. Final settlement of the Retablissements, completion of legal issues (compensation negotiations because of changes to building foundation lines, etc.). ${ }^{395}$

These points were not always performed in this exact order, but there was basically a a scheme, and a procedural form that was astounding for the early modern period. We will also encounter the same impressive organizational will (if not always force) in regard to fire insurance, as will be discussed in a later chapter. To illustrate just point nr. 7 , we might take a look at the model sketches drawn for the rebuilding of the small Kurmark town of Seelow after the fire of 1788 .

The rebuilding administration was planning with 10 different types of buildings (Figure 62), starting with "a preacher widow's house", with its interior and stable, a "farmer-citizen house" with its stable including space for horses and cattle - the term "farmer-citizen [Ackerbürger]" denoted the upper class citizen who had rights of lease or property of land outside the city which they were effectively cultivating like a large farmer but were recognized as citizens of the city, living there -, houses for "middle class citizens [Mittelbürger Wohnung]", for "Lower Class citizens [Kleinbürger Wohnung]", and for shepherds [Hirtenwohnung].

On the one hand, transforming the procedural steps into the written form of reconstruction ordinances facilitated the direction of local activities from the far away headquarters in Berlin (or from the respective "subheadquarters" of the seats of the district administration and the local commissioners [Steuerräte]); on the other hand, this written form also functioned at the headquarters to create an archivable objectification of the process, which could be used again in subsequent cases. Pressure imposed by reconstruction ordinances and the inclusion of the Crossen ordinance in the Corpus Constitutionum Marchicarum also reinforced this process. In communities that independently organized reconstruction efforts, this process was quite different: such communities rarely successfully created "an image of themselves" as an object of observation. Thus, there is no existing evidence of such administrative operations for most smaller and midsized imperial cities in Germany, nor for many territorial cities that were not yet tightly integrated within the administrative network by the eighteenth century. Once in a while, one encounters reconstruction plans for these types of cities, but often they are entirely absent.

395 These scheduling patterns are somewhat abbreviated and based on Jaeckel, "Erneuerung," pp. 400-02. 

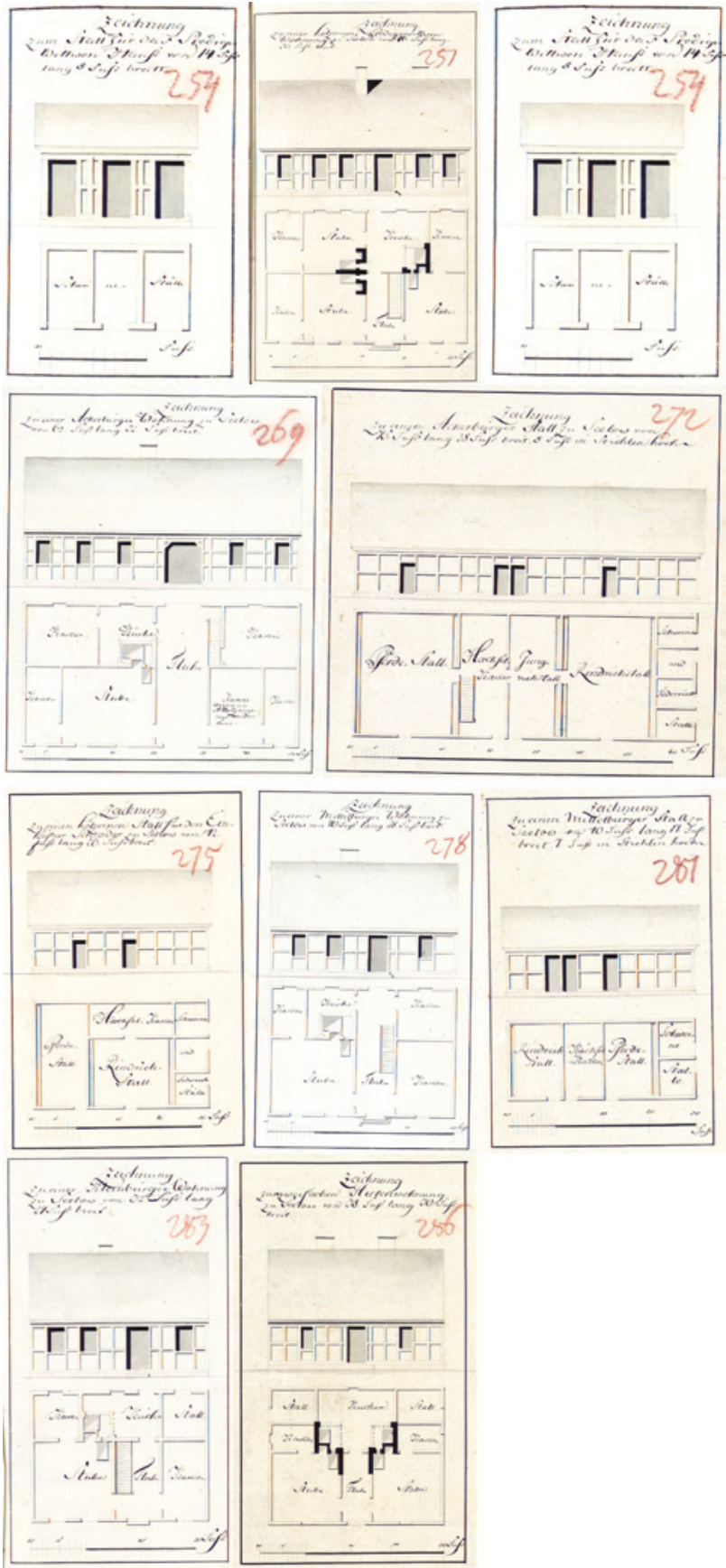

FIGURE 62 Model sketches for houses that served the Kurmark rebuilding administration, and the architects as patterns for reconstructing the town of Seelow in 1788: each citizen had a right to a given type of building according to their "class" and as they were taxed; there was no individual rebuilding and freedom of choice about how to rebuild (BLHP Potsdam Rep. 2 S7247) 
In Prussia, a type of self-sustaining discourse arose within the country, involving the Prussian territorial city administration, the building department, the CWD, and the General Directorate. A "virtual image" of the country circulated, which was manipulated and constantly changed, but which still aimed at a certain ideal, and which was fostered and framed by the various "improvement" campaigns. Likewise, though to a far lesser degree, imperial city administrations also possessed a self-generated view of their cities as malleable objects capable of being shaped. Within these circles of state communication, every city fire was perceived as a chance, as a new opportunity.

Let us examine one such process in detail:

On May 8, 1801 a fire broke out in the small town of Lebus, located a few kilometers north of Frankfurt an der Oder, which destroyed approximately 40 per cent of the town of 1160 inhabitants, including the church and schoolhouse: 41 burgher homes and 28 cottages along with many barns were reduced to ashes. Lebus, at this point, was a largely insignificant town. Nevertheless, it traditionally belonged to the 34 "mediate" cities of the Prussian central province of Kurmark. ${ }^{396}$ The inhabitants of Lebus were divided into three social groups: farmers, burghers, and poorer people living in cottages (Büdner). The farmers possessed arable land, burghers possessed only meadows for raising livestock, and the Büdner possessed no land at all and worked either as skilled craftsmen (Profeßionisten) or as day laborers for the merchants. ${ }^{397}$ As was usual in premodern times, the fire spread quickly due to the straw and thatched roofs and could not be extinguished. ${ }^{398}$

Following the fire, the reconstruction machinery asserted itself: after the city magistrate and Oberamtmann (district head) Gülle had informed the responsible commissioner, Steuerrat Zöller, ${ }^{399}$ the damage was assessed and reported

396 Klaus Vetter, "Lebus," in Städtebuch Brandenburg und Berlin, ed. Evamaria Engel, Stuttgart 200o, p. 280; Vetter, Zwischen Dorf und Stadt, pp. 19-24; Jaeckel, "Erneuerung," pp. 154-59.

397 Cf. corresponding notes in the input of the lower class (Kleinbürger, petite bourgeoisie) and of the peasants of Lebus to the the king, Lebus 16 June 1801, BLHA Potsdam Rep. 2, S 5526, unpag.; Vetter, Zwischen Dorf und Stadt, pp. 73-93.

398 Steuerrat Zöller to the Kurmark CWD, Frankfurt an der Oder, 16.1801, BLHA Potsdam Rep. 2, S 5526, unpag.

399 Regarding the local commisioners (Steuerräte), see Otto Hintze, Der Commissarius und seine Bedeutung in der allgemeinen Verwaltungsgeschichte (1910), reprinted in Otto Hintze, Staat und Verfassung. Gesammelte Abhandlungen zur allgemeinen Verfassungsgeschichte, ed. Gerhard Oestreich, Göttingen 1970, pp. 242-74. 
to the appropriate CWD authorities on May $16 .{ }^{400}$ According to the report submitted to the highest authority, the General Directorate, Zöller's proposals were approved in the name of the king on July $15 .{ }^{401}$ With little regard for their unpleasant living conditions, the inhabitants of Lebus were, up to this point, left in temporary accommodations in stables and barns, leaving livestock with no roof over their heads. Over two months after the fire, on July 17 , there was finally a thorough site inspection, from which Conducteur Lietzmann generated a "situation map" based on the state of the city before the fire with the fire-destroyed sections sketched in, as well as a "reconstruction map" for future building development. The core of the transformation would result in a straightening of the roads, the construction of buildings in a straight line to achieve "more regularity," as well as the reclamation of additional space effected by banning barns within the city limits. Building Inspector Berger created model sketches for burgher houses, Büdner cottages, and stables, which served as the standard for all future buildings. ${ }^{402}$

Since reconstruction using solid materials was deemed unfeasible due to cost, half-timbered buildings with solid fire gables and tiled roofs were recommended. The costs for reconstruction were only partially borne by the residents themselves: of the estimated total construction costs of 66,596 Rtl., 47,496 were provided by the fire fund, $743 \mathrm{Rtl}$. were paid through construction aid, 9,176 Rtl. were paid by the homeowners themselves, and 9,176 more were added to that through state funds. This suggests that the fire fund was actually relatively effective, as the affected individuals only had to contribute 14 per cent of the total sum in actual costs at the time of reconstruction. ${ }^{403}$ When questioned if the church could be built on its old foundations, the General Directorate approved this as an exception, but complained about the previous reconstruction of 13 houses and 25 stables. ${ }^{404}$ The preferences of the owners to rebuild their land 1:1 were taken too seriously, thereby impeding the opportunity to implement more effective measures:

\footnotetext{
400 B B HA Potsdam Rep. 2, S 5526, unpag.

401 General Directorate to the Kurmark CWD, Berlin, 15 July 1801, BLHA Potsdam Rep. 2, S $55^{26}$, unpag.

402 BLHA Potsdam Rep. 2, S 5526, unpag.; Gerhard Fehl, "Perspektivischer Stadtraum. Modellmäßiger Hausbau. Zum planmäßigen Stadt- und Wohnungsbau zwischen 15. und 18. Jahrhundert," in Tilman Harlander (ed.), Stadtwohnen. Geschichte, Städtebau, Perspektiven, Munich 2007, pp. 19-45.

403 Zöller to the Kurmark CwD, Frankfurt an der Oder, July 17, 1801, BLHA Potsdam Rep. 2, S 5526, unpag, also Frankfurt an der Oder, August 12, 1801.

404 Zöller to the Kurmark CWD, Frankfurt an der Oder, September 17, 1801, BLHA Potsdam Rep. 2, S 5526 , unpag.
} 
In the meantime, even you must see in your unbiased judgement, that a Retablissement plan involving the preservation of the old foundations of burned buildings hardly deserves to be called a Retablissement plan, and that if this is the basis for reconstruction, a proper Retablissement will never be actualized. 405

Several builders had built stables as instructed, but then added unsanctioned details, such as large main doors and "hay floors covering the stables" - as in a barn, residents could thus store a "necessary supply of feed for [their] livestock" in the stables, because in the winter it was impossible to transport hay from the barns on the far bank of the Oder River.

For one thing, as so-called citizens, we have nothing else in common with the citizens of other cities than the name, because we neither operate in an urban economy nor do we live the same lifestyle. Our revenues are based only in the meadows given to us that we can use to our greatest advantage not otherwise than by keeping a proportionate number of livestock on them. How could we possibly responsibly care for them and ensure their protection, if their feed must kept on the far side of the Oder in the designated barns, and if we are only allowed to fetch a supply that is sufficient for only a few days from there? ${ }^{406}$

The Lebus residents therefore circumvented the official Retablissement plan by building stables with state subsidy funds that could also be used as barns. The abstractly envisioned ideal image of the city was not realized according to plan: the long-term ideas of the planners collided with local inertia. The residents of Lebus argued for their lack of "authentic urbanity" - an argument, which in other contexts, had it concerned the preservation of their city status, would certainly never have arose.

War losses were handled in the same way as the fire losses in the tiny town of Lebus - examples being the small fortress town of Peitz and also the more important fortress city of Küstrin, both of which were bombarded and set on fire in 1758 . In these cases, in addition to the usual processes in place since the beginning of the century, a precise reconstruction map was drawn (See above fig. 52: Reconstruction map of Peitz after the Fire of June 23, 1758) and detailed

405 General Directorate to the Kurmark CWD, Berlin, September 25, 1801, BLHA Potsdam Rep. 2, S 5526, unpag.

406 Meeting minutes, Lebus, November 26, 1801, conveyed to the Kurmark CwD by the magistrate, BLHA Potsdam Rep. 2, S 5526, unpag. 
reconstruction regulations were created and printed. ${ }^{407}$ These regulations focused particularly on the exact designation of the prices and labor costs that could be charged for materials and construction work. This was legitimized by the fact that the largest part of the money made available was of a public nature: it either came from the fire funds or-as in the case of Küstrin-from a specific royal grant of 200,000 Rtl.

The general planning approach at work here clearly falls into the perceptual schemes and procedures described by James C. Scott—admittedly with somewhat teleological and ideological critical undertones-as "state simplifications." They have already been partially evaluated for the eighteenth-century from an environmental-historical perspective in the field of forestry science and in relation to Prussian land reclamation (drainage) projects. ${ }^{408}$ The longterm orientation expressed in the current context is clearly reflected in the administrative language: "Melioration," the improvement of the entire country, is the goal, the terminus technicus embodied by "Retablissement." As the above quote illustrates, the goal is not the restoration of what was lost, but rather new construction according to an idealized plan through the erasure of old structures. "Retablieren" refers only to the restoration of value, however the goal of growth is de facto implied here (which is why the insistence on the exact re-construction of the city, is, somewhat counterintuitively, deemed not to be a "Retablissement"). The administration thus implicitly negates the distinction between Établissement and Rétablissement, which is otherwise linguistically implied. ${ }^{409}$ These reconstruction protocols were part of a wealth of large government programs leading to "Retablissement plans for Kurmark cities" (1767) and to the "general plan for the Retablissement of the healthy state of Kurmark cities" (1770) following the great destruction caused by the Seven Years' War. These large rétablissement projects were projecting somehow the Prussian cities, eventually even the Frederician state as a whole, into an ideal future yet to be realized.

In later periods, one can see the emergence of truly temporal (rather than spatial) utopian visions in the zero hour, imposing their influence on the process of reconstruction. After the Hamburg fire of 1842, for example, the manufacturing entrepreneur Harel wrote to the senate from Paris, calling for the

407 Building regulations for the reconstruction of the city of Küstrin in 1758, BLHA Potsdam Rep. 3 Nr. 10445 .

408 See James C. Scott, Seeing Like a State: How Certain Schemes to Improve the Human Condition have Failed, Princeton 1998, pp. 1-52; Blackbourn, The Conquest of Nature, pp. $33^{-96}$.

Too strictly divided with Jaeckel, "Erneuerung," pp. 66-89. 
concord and communality of all civilizations particularly in times of misfortune, and advertised the plan to rebuild Hamburg with houses equipped with metal roofs on which gardens would be planted: the soil on the roofs would prevent any spread of fire and the city would be transformed into a paradise of clean air. The project of the garden-roof city actually turned out to be verbatim implementation of passages from Mercier's L'an 2240: "Oh if only my century could see a new Babylon and marvel at the gardens of Semiramis!"410 Utopian thinking is often sparked by disaster and the chance it affords to create new beginnings. Once again, however, these utopian ideas conflicted with the actual reconstruction work that had already begun.

\subsection{Panaceas: from "Local Knowledge" to Science and Back Again to Popular Enlightenment}

Questions concerning fire policey were highly important for Enlightenment science, due in no small part to their central importance for municipalities. This is indicated by the strong representation of the problem in corresponding media as well as its emergence as a topic for academic prize essays, and, similarly too, by its presence in the cameralist compendia of the academic field of "policey science" (Policeywissenschaft). "Accidents" (Unglücksfälle) — as natural disasters and extreme events were called, from the Latin "casus fortuitus" - represented the most striking break in the sought-after state of enduring happiness in a well-managed society. ${ }^{411}$ Under the influence of the eudemonistic idea of the state, administrators were constantly searching for ways to eliminate accidents through inventions and improvements. Thus, there emerges the sense of a sort of laboratory of the economic Enlightenment existing within the network of public business and administrative discourse across the German states and territories. In the field of scientific discourse there were, for example, several academic prize questions dedicated to the fire problem, which were sponsored by scientific academies and societies - for example, the $175^{6}$ prize question of the Royal Society of Sciences in Göttingen: "How to fix a specific humidity in lumber through moistening it and coating it, so that it does not easily catch fire; and how to make this application not too expensive and effective for at least

410 HStA Hamburg Best. 323-1 (Rat- und Bürgerdeputation von 1842), Nr. 142, Harel to the senate, Paris, May 24, 1842, unpag.

411 As a broad overview and without a precise evaluation of conceptuality, it has been suggested by Torsten Meyer, "Sicherheit durch Erfindungen. Zur sozialen Bedeutung der Technologie im ausgehenden 18. Jahrhundert," in Gerhard Banse and Hans-Peter Müller (eds.), Johann Beckmann und die Folgen. Erfindungen-Versuch der historischen, theoretischen und empirischen Annäherung an einen vielschichtigen Begriff, Münster 2001, pp. 191-200. 
several years; or where required, how to renew it without incurring too great a cost."412 Another prize question was advertised by the same Göttingen society in 1772: "Demonstrate interventions that are cheap and correspond to local (Göttingen or even all of Hanover) state constitutions, which in their execution function 1) to improve the fire extinguishing procedures in small towns and in rural areas, and 2) to quickly gain control over potential conflagrations." ${ }^{413}$ In Prussia, there were functional and labor divisions between the Academy of Sciences and the General Directorate in matters of fire safety (a distinction of tasks that was established shortly after the founding of the Academy in spite of Leibniz's opposition). While there is no evidence of a single prize question concerning fire policey offered by the Academy (1745-85), in the 1770s alone, the General Directorate advertised several related prize questions. ${ }^{414}$ Between 176o and 1795, in addition to the already mentioned Göttingen and Berlin prize essays, nine additional prize questions divided between three academies in Germany have been identified. ${ }^{415}$ In Denmark, which was recognized as a contributor to the cameralist German Enlightenment discourse because in part, it shared a common scientific language, a prize question appears in 1795 in the Royal Society of Sciences in Copenhagen: "What is required to form a fully functional administration of fire prevention and resilience in larger cities?"416

412 Göttingische Anzeigen von gelehrten Sachen 141 (1756).

413 Göttingische Anzeigen von gelehrten Sachen (1774), part 144; The next four submitted prize writings were judged negatively by the prototechnologist Johann Beckmann: "Alle vier Abhandlungen scheinen mir sehr mittelmäßig zu sein, nichts wesentliches Neues zu enthalten, und auch in Anwendung bekannter Sachen nichts lobenswürdiges zu haben." (Beckmann to the society November 3, 1773) — the prize question was thus re-published once more in 1773. Glaser and Heinemann were chosen from the relatively numerous submissions (Göttingen, Archiv der Akademie der Wissenschaften, Scient. 196, vol. 10, Fasz. 29; cf. Rebecca Knapp, Eine Wissensgeschichte der Feuersicherheit. Kommunikation über Brandbekämpfung zwischen 1600 und 180o, PhD Diss., Ruhr University Bochum 2013, p. 70). The winning contributions were then published in the Hannoverischen Magazin 44 (1775). On Enlightenment academic prize contests in general, see for France Jeremy L. Caradonna, The Enlightenment in Practice. Academic Prize Contests and Intellectual Culture in France, 1670-1794, Ithaca 2012.

414 Thus in $177^{-7}-73$ there were two prize writings relating to fire extinguishing machines, which would be suitable for serial distribution in rural areas and relating to fireproof roof construction, vgl. Knapp, "Wissensgeschichte," p. 67 f.

415 They concern the wood coating, the construction of fireproof roofs, the improvement of fire extinguishers, the improvement of firefighting practices in general, rescuing property items during a fire, the planning and construction of more fire resistant villages; cf. Knapp, "Wissensgeschichte," appendix 1, p. 255f.

416 Prize question from June 11, 1796 of the Royal Society of Sciences in Copenhagen, in Schleswig-Holsteinische Provinzialberichte 9 (1795), pp. 224-27. 
These prize competitions represent only the tip of the iceberg of an economic Enlightenment discourse which both preceded and extended beyond the prize essay discussion. Significantly, this discourse also operated outside of publicly printed materials, for example, in the correspondence of administrators and in projects proposed to the fire policey authorities. ${ }^{417}$ Continually improving models and corresponding sketches of fire hoses were submitted to magistrates and governments everywhere. There were also somewhat adventitious advertisements for legendary "fire extinguishing machines" which unfortunately were accompanied by no exact descriptions or drawings: either those have not survived or they were not communicated at all, as the inventors usually tried to keep the secret for a long time as this was the only asset they could sell. ${ }^{418}$ Such projects and proposals were generally concerned with two major themes: first, improvements in the extinguishing capacity of water, and second, the possibilities of a fire-protective coating for wood. These projects consistently attracted the attention of city and territorial administrations and some of the project proposers may have perhaps written more cautious applications, had they known that the administrations had already slowly accumulated a series of similar such proposals within their archives.

In late October 1698 , the former imperial, later Hanoverian, artillery captain, Johann Franck of Nordhausen/Harz, appeared in Hamburg. Supposedly, "he had muddled around in the art of fire and had learned many sciences, even secreta and arcana ... over the course of many wars," including in the war against the Ottomans for the emperor of the Holy Roman empire, and was thus in a position to offer the production of a cheap "extinguishing water" for the municipal water tanks positioned at strategic points around the city, which could then be used in the extinguishers (fire hoses with and without movable pipes)

417 Cf., for example, the separate fonds “'[Ökonomische] Projekte und Erfindungen' des 166o gegründeten preußischen Consilium Oeconomicum" (GStAPK Berlin Hauptabt. I, Rep. 9, Nr. C6a1).

418 Hinrich Christian Schultz, for example, wrote an introduction while advertising his invented machine, addressing it to the members of the council, but he did not reveal enough details to enable the addressees to grasp the core of the project: "Wird zweifels ohne annoch in Jhren andencken schweben, wie vor einiger zeit [ich] die genug zu rühmende gnad gehabt, die Probe der so geschwind feüerlöschenden Machine vor dero erläuchtigste Augen, untertähnigst darzu legen. [Die Maschine wäre von nur drei Personen zu bedienen, er habe sich damals, wie es] einjeder Mechanicus zu tun pflegt, der nicht allemahl so gleich seiner bewegenden ursachen halber alle Vortheil so gleich entdeckt." He wanted to "reserve" such details, and requested from the council the promise of a priviledge, so that nobody other than he might be able to build the machine ("niemand als ich solche Machine verfertigen möge”) (Hamburg, June 26, 1722, HStA Hamburg Cl. viI Lit. Fe Nr. 2, vol. 12a). 
in case of fire. ${ }^{419}$ Similar, half-alchemical recipes, billed as secret "arcana" of the "virtue of water," were adopted by fire policey writers. ${ }^{420}$ They amounted, more or less, to recipes of how to make water more effective as an extinguishing agent through the addition of specific chemicals and elements, and occasionally, the same water mixture was also touted as a coating to make wood virtually fireproof. Johann Gerlach Wilhelmi, a captain in a Prussian grenadier regiment until $1716,{ }^{421}$ presented an "antipathy against fire" in 1721 in Hamburg with a relatively exact recipe for a water mixture that could serve as an extinguisher as well as a coating for wood. ${ }^{422}$

An "A. Bräef or Brach" advertised in Cologne in 1736 for a similar miraculous substance, which he also praised as originating in England-after the London fire of 1666, one could presume that the English possessed particular expertise concerning fire. He praised the "Veritable Secrets, from the widely famous English fire water, and how it is prepared in England." Supposedly, "noble people and persons of position kept this [fire water] in their homes as a precaution (against outbreak of fire)" and it was used "in the sudden outbreak of fire" before an alarm had even been sounded in the city and before one could count on assistance from the fire hoses or even from any helping hand, and it is established by many experiments, that this prepared fire water, in addition to divine providence, has saved many beautiful homes and

419 HStA Hamburg Cl. vir Lit. Fe Nr. 2, vol.11.

420 Ibid.

421 See Wilhelm Werner Kurt von Priesdorff, Offizier-Stammliste des Grenadier-Regiments König Friedrich Wilhelm IV. (1. Pommerschen), no. 2, Berlin 19o6, no. 511, p. 184: born around 1680, Fähnrich (ensign) since 1711, retired in 1716 .

422 "Antipathie wider das Feuer

$\begin{array}{ll}\text { R. Kreyde } & 10 \text { pfundt } \\ \text { Alaune } & 20 \text { pfundt } \\ \text { Potasch } & 5 \text { pfundt } \\ \text { Bleiasch } & 5 \text { pfundt } \\ \text { Vitriol } & 8 \text { pfundt }\end{array}$

Diese sachen werden sehr pulverisieret und kommen zu einer Tonne Wasser, man nimpt einen großen Kessel, wo eine Tonne Wasser kan eingekochet werden worinnen nun eine halbe Tonne Wasser siedendt heiß werden lässet, dan must man die Kreyde, jhns selbige algemötlich eine Handvoll nach der andern hierein im Wührmchen ['worm-like' meaning stirring, forming a funnel in the liquid for receiving small portions of the chalk one after another] hienein thun uber diese sachen muß alle zeit einer rühren damit alles wohl zergeht, und sich nichts am grundt setze. [...]." Later the addition of 12 pounds of clay was also recommended: "Wo dieses Wasser rauff kömpt brendt das Holtz in keiner halben stunde, wan es auch in völliger glut lieget" - Hamburg, 17 Jan. 1721, dorso: "Recept das Wasser zu kochen" (HStA Hamburg Cl. vir Lit. Fe Nr. 2, vol. 11). 
buildings. Though they had sometimes already completely burst into flames, through this fire water the flames were fortunately put out before the fire hoses had even arrived. ${ }^{423}$

Until the early eighteenth century, it is clear that many of these "projects" were proposed by "project makers" (Projektemacher), or even by "quacks [Quacksalber]"-individuals who probably did not have regular work, such as soldiers and officers who had been released from service. The proposals circulated only in this administrative context, and while they appear in the archives of the fire policey authorities, they rarely appeared in print.

Proposals submitted after 1750 were similar in content, but now they were proposed by physical-economic Enlightenment scholars. Among them was perhaps the most active and best-known contemporary self-declared expert, doctor of medicine and physician of the Thuringian city of Suhl, Johann Friedrich Glaser (1707-83), who was also a member of the Leopoldina and an honorary member of the Electoral-Saxon Economic Society in Leipzig. Glaser, the son of an executioner, studied medicine in Erfurt and Altdorf and completed his doctorate in Hardwijk. ${ }^{424} \mathrm{He}$ was personally affected by the fourth major fire in the city of Suhl (following those of 1509, 1590 and 1634) on May 1, 1753, and this experience seems to have left a deep impression: from that point onwards, he dedicated his life's work from then on to the improvement of fire policey. In 1756 he published the first edition of his burgeoning fire policey compendium; the fourth edition appeared in 1772 and became almost a standard handbook for every little administrative office in the German territories and cities. ${ }^{425}$ In the same year, the Göttingen Society of Sciences published the prize question mentioned above soliciting proposals for a fire-resistant wood coating, and Glaser's submission was awarded the prize. ${ }^{426} \mathrm{He}$ had tried various techniques, such as soaking the wood in salt water, soaking it in vitriol, and painting the wood

423 HStA Köln, V+V N 863, f. rr-v: the water would then have the positive effect, of preventing pests, worms, spiders, etc. in the wood.

424 "Beytrag zur Lebensgeschichte des vor kurzen verstorbenen Arztes, D. Johann Fridrich Glasers," Journalvon und für Franken 6 (1793), pp. 411-23; on him now Ruth Schilling,Johann Friedrich Glaser (1707-1789). Scharfrichtersohn und Stadtphysikus in Suhl, Vienna 2015.

425 Johann Friedrich Glaser, Nützliche und durch die Erfahrung bewährte Vorschläge, bey heftigen und geschwinden Feuersbrünsten Häuser und Mobilien sicher zu retten [...], 4th much expanded and improved edition, Hildburghausen 1772.

426 First published in Hannoverische Beyträge zum Nutzen und Vergnügen 3 (1761), 84. In part, 19 October 1761, pp. 1321-80, then as a separate edition: Johann Friedrich Glaser, Preisschrift, wie das Bauholz in den Gebäuden zu Abhaltung grosser Feuersbrünste, leicht, wohlfeil, bewährt und dauerhaft zuzurichten, daß es nicht leicht Feuer fange oder fortbrenne, with notes, clarifications, and improvements, Hildburghausen 1762 . 
with a "delicate" slurry of glue and clay. He documented experiments (e.g., the experiment of the "21st of August in the year $176 \circ$ ") and finally sent the society a piece of wood covered with his recipe in order for it to be tested.

After this successful endeavor, his advertising efforts for the recipe intensified: in 1773 he finally found two sponsors, the Economic Society in Leipzig and, interestingly, the Society for the Promotion of Arts and Useful Industries in Hamburg. It is not surprising that this issue resonated particularly well with the practically oriented Enlightenment milieu of Hamburg. Glaser had wrested the financing from his sponsors for several experiments-in particular, the comparative burning of three full houses with and without his miracle solution. As typical in such matters, a list of reliable witnesses was published with the findings and the exact elapsed time of the burning process was included; a copper engraving further clarified the operation. ${ }^{427}$ Although his wood application spent nearly twenty years basking in the light of academic honor, a critic finally emerged: an author "W.," who remained anonymous, published a tiny miscell in a Hanover magazine in 1773 , reporting that he tried out the recipe comprising "a slurry of glue, with one part slurry of clay, and one part flour paste ... but there was not a single trial in which it proved to be reliable." Furthermore, he claimed, the flour paste functioned more as a fire propellant than a fire retardant. ${ }^{428}$

Glaser felt challenged by this brief objection and published defenses and also further works on firefighting. ${ }^{429}$ In 1772 , he also won the Göttingen learned

427 Johann Friedrich Glaser, [A] usführliche Beschreibung der glücklich abgelaufenen großen Feuerprobe, welche mit seinem erfundenen brandabhaltenden Holzanstriche [...] öffentlich gemacht worden [...], Leipzig 1773 .

428 W., "Ueber die Abhaltung des Feuers vom Bauholze," Hannoverisches Magazin 11 (1773), p. 1631 .

429 Johann Friedrich Glaser, Beantwortung und Widerlegung verschiedlicher wider seinen erfundenen und in der damit an etlichen kleinen Probehäusern öffentlich angestellten und glücklich abgelaufenen großen Feuerprobe bewährt befundenen brandabhaltenden Holzanstrich gemachten ungegründeten Einwendungen und erregten Zweifel, Leipzig 1774. A sober review is found in Allgemeine deutsche Bibliothek 25, no. 1 (1775), p. 310; Johann Friedrich Glaser, Ausführliche und auf richtige Erfahrung gegründete Abhandlung und Vorschläge, wie thunlicher Weise die meisten Feuerbrünste an und in den Gebäuden wohl verhütet [...] werden können, Dessau 1783; an annoyed review in Allgemeine deutsche Bibliothek 56, no. 1 (1783), pp. 301-05, which finds the proliferation of Glaser to be "bey nahe ekelhaft" (almost revolting); Glaser, Beweisgründe, daß und warum die in seiner gedruckten Schrift: Abhandlung und Vorschläge, wie die meisten Feuersbrünste zu verhüten, viel wirksamer und gewisser sind, als die bisher gewöhnlichen, Schleusingen 1784, newly reinvigorated by the annoyed tone of the review regarding Glaser's belief that he was the single, unchallenged fire expert of Germany, Allgemeine deutsche Bibliothek 61, no. 2 (1785), pp. 6o6-o8. 
society's second call for prize essays. ${ }^{430}$ Here too, he had to defend himself against the second-place candidate, Johann Wilhelm Heinemann, who not entirely without reason, accused Glaser of excessive verbosity, complaining that he "bombarded his readers with a mass of minutiae, that one does not want to know because they are already long known." ${ }^{431}$ Glaser stressed that there was a method behind his prolixity: his texts are "laboriously and clearly written with diligence ... so that they can and will be correctly understood and employed by everyone, even by common people, for whom knowing such things is particularly useful and necessary." ${ }^{32}$ Glaser, himself of lower-class descendance, definitively considered himself to be a promotor of popular Enlightenment and took this as his mission. Reviewers decided his application had a certain effectivity: of course it would wash away in a heavy rainfall, and even if it did not actually ignite in flames, coated wood would still at least smolder; nevertheless, treating wood would help slow the spread of fire. ${ }^{433}$ However, quite a few reviewers became increasingly weary of Glaser's publication mania: "Into his old age Mr. D. Glaser never stopped [talking] about fire deterrents and extinguishing methods, sending one treatise after another into the world." 434

Beyond Glaser's recipe, other competing but only slightly different mixtures circulated, such as that of Ewald Friedrich Herzberg $(1774)^{435}$ and Lord Mahon

430 Cf. note 551: Johann Friedrich Glaser, "Von Verbesserung der Feuerlöschungsanstalten in den kleinen Städten und auf den Dörfern hiesiger Lande," Hannoverisches Magazin 13, no. 44, June 2 (1775), pp. 689-736; also published separately (Leipzig 1775); see reviews in Allgemeine deutsche Bibliothek 28, 2 (1776), pp. 515-18; Johann Friedrich Glaser, Fernere Erörterung und Aufklärung seiner verbesserten Preisschrift, von Verbesserung der Feuerlöschanstalten [...], Hildburghausen 1779 .

431 Johann Wilhelm Heinemanns von Königl. Societät der Wissenschaften zu Göttingen, zuerst gekrönete Abhandlung über die Feuerlöschungsanstalten in kleinen Städten und auf den Dörfern, Lemgo 1777 qtd. Glaser, Fernere Erörterung und Aufklärung, p. 11. The prize essay itself was first published in 1775: Johann Wilhelm Heinemann, "Anzeige der Mittel, die in der Ausführung thunlich, nicht gar zu kostbar und der Braunschweig. Lüneburgischen Landesverfassung angemessen sind, wordurch a) die Feuerlöschungsanstalten in den kleinen Städten und auf dem Lande zu verbessern, und b) Dem schnellen Ueberhandnehmen einer Feuersbrunst zuvorzukommen sey," Hannoverisches Magazin 13 (1775), parts 14-16, pp. 211-44.

432 Hannoverisches Magazin 13 (1775).

433 J. H. Lambert, "Rezension der 'Feuerprobe," Allgemeine deutsche Bibliothek 21, 1 (1795/96), pp. $306 f$.

434 Review of Glaser's fire extinguishing attempts in Allgemeine deutsche Bibliothek 68, 1 (1786), pp. 302-04.

435 Ewald Friedrich Herzberg, Vorschläge zur Verbesserung der bisher üblichen Dächer, Breslau 1774; supplement Breslau 1779. 
(1777) ${ }^{436}$ It was obviously clear to publishers and writers in Enlightenment discourse that there were no revolutionary inventions to be discovered in this field within the context of an overall unchanged and even pre-Lavoisierian epistemic framework; at most, things that were already known could be clarified and widely communicated. This enactment of popular Enlightenment had an impact on urban and territorial fire safety. Hamburg, which had already contributed to the financing of Glaser's attempts in 1773, was confronted again twenty years later with a similar "invention," publicized by Swedish assessor Franz Joachim van Aken and sent to the senate of the city. Again logs from fire experiments on houses were featured; they had been painted with an alumvitriol solution and therefore burned less quickly than the others or not at all. Senator Günther submitted the printed descriptions of the experiment, testified to by a large number of honorable observers, ${ }^{437}$ to the Hamburg Society for the Promotion of Arts and Useful Industries, which in its 48th meeting (March 27, 1794) charged four individuals with its evaluation: Brodhagen, the pharmacist Thorey, Deputy Fire Chief Scharf, and border warden Reinke. ${ }^{438}$ Thorey, in particular, dispensed very hesitant judgments:

It has been known for centuries that solutions of different types of salts are excellent: alum, vitriol, and alkalis have been used not only to extinguish fires but also, through their application (particularly of alum and vitriol solutions), have been used to protect buildings against fire. Because these solutions are difficult and costly to produce and implement, the usefulness of them is not generally known. ${ }^{439}$

In particular, the chemically experienced evaluators warned that the brine would destroy the fire hoses made of canvas and leather and that the clay slurry would clog the valves and pipes. In light of these significant criticisms the senate decided against implementing the solution.

436 [Sholto Percy], The Percy Anecdotes, Revised Edition, 2 vols. (New York: 1845), vol. 1, p. 76 f.

437 "Protocolles, concernant les expériences faites par le Sieur François Joachim von Aken, Assesseur, contre les progrès des incendies, Stockholm 1793" (HStA Hamburg Cl. vII Lit. Fe Nr. 2, vol. 12b n. 2); on this see the hand-written Swedish description in HStA Hamburg Cl. vir Lit. Fe Nr. 2, vol. 12b, n. 3; the first edition (Örebro 1793) in addition to the French and Swedish versions contains: "Försök til Eldsäckning och Brandskadors förekommande: Protocoller."

438 "Protocoll-Extract der Hamburgischen Gesellschaft zur Beforderung der Künste und nützlichen Gewerbe acht und vierzigste Versamlung, d. 27. März 1794" (HStA Hamburg Cl. viI Lit. Fe Nr. 2, vol. 12b, n. 4).

HStA Hamburg Cl. vir Lit. Fe Nr. 2, vol. 12b, n. 4. 
The Hamburg specialists were revisiting a question that had been discussed in the city thirty years earlier. On August 6,1767 , the famous lightning bolt hit the Nicolai tower. It should result in Reimarus becoming a "prophet" of lightning rods. ${ }^{440}$ On the day itself, the syndicus Faber sent immediately a request to the saltworks in Lüneburg and through them eventually questioned the Halle saltworks about whether it might be possible to store a certain quantity of Lüneburg source water, i.e. a strong salty brine, in the church towers, since this was supposedly more suitable for fire extinguishing than plain water. Syndicus Kraut at the salt headquarters of Lüneburg replied on September 25 that they did not use brine for this purpose because it "eats away at the leather on the fire hoses, and ... doesn't appear to improve or change the efficacy in any way". Instead, they used a barrel of vinegar on the church towers; ${ }^{441}$ but the request was forwarded to Halle's local salt count Johann Christoph von Dreyhaupt, who had eagerly experimented in this area and published in the same year as Johann Friedrich Glaser. In Halle, brine was indeed used for fire extinguishing, since one bucket of the salty water supposedly had the extinguishing power of $3-4$ buckets of normal water. Halle brine was also supposedly superior to sea water because it contained 20 lots of salt, while sea water contained only 4 lots; Halle brine was therefore heavier and thus longer lasting during firefighting efforts. Dreyhaupt had designed a special fire extinguisher capable of spraying water especially long distances ${ }^{42}$ and strongly argued that the "old superstitions were completely wrong": the notion that "fire caused by lightning could only be extinguished with milk is quite false, as we see from experience, ... while the elemental fire of lightning [is] indeed very subtle in and of itself, when it ignites woodwork or other things, the resulting fire becomes a common fire, like a common hearth or kitchen fire. ${ }^{\prime 43}$ Dreyhaupt also included a recipe, which again relied on salt and alum, for use if natural brine was not to hand. He disputed the idea, addressed so sharply by the pharmacist Thorey a few decades later in Hamburg, that saltwater could damage fire hoses, stating that it was safe

\footnotetext{
440 Cf. p. 127.

441 Letter exchange in HStA Hamburg Cl. vir Lit. Fe Nr. 2, vol. 14.

442 HStA Hamburg Cl. vir Lit. Fe Nr. 2, vol. 14, Dreyhaupt's letter to a professor of theology "Nosfelt?", Halle, 1o Nov. 1767-Dreyhaupt claims he also introduced these fire hoses in two articles in the Göttingische Anzeigen von gelehrten Sachen in 1753 eingestellt-he is in error here, they are found in the Hannoverischen Gelehrten Anzeigen 3, 92 (1753), pp. 1361-64. The particular fire extinguisher is also mentioned in another one of Dreyhaupt's publications: Johann Christoph von Dreyhaupt, Pagus neletici et nvdzici, oder diplomatisch-historische Beschreibung des Saal-Creyses [...], part 2, Halle 1773, p. $388 f$.

Ibid.; HStA Hamburg Cl. vir Lit. Fe Nr. 2, vol. 14.
} 
as long as the hoses were flushed with normal well water or river water after use with saltwater.

These sources from Hamburg and other places clearly demonstrate how the "popular Enlightenment" constructed itself and located its themes: the fireretarding effects of alkaline solutions and saltwater had actually been known for a long time, and members of occupations that often encountered fire, for example artillery soldiers, were very well aware of these effects. Whether this historical-anthropological knowledge should be classified as "local knowledge" is still up for debate, ${ }^{444}$ but it was not "tacit knowledge" in Polanyi's sense, because the project maker could easily publish it and widely communicate it. ${ }^{445}$ As the older form of policey administration increasingly transformed itself into a scientifically informed cameralism, the development of a supply and demand market for projects and mechanisms intensified accordingly—thus proposals for recipes are found in the archives dating from the late seventeenth and early eighteenth century. From $175^{\circ}$ on, a reversal takes place so that "knowledge from below" no longer reaches the administration; rather, promoters of "popular Enlightenment" and specialist administrative officials like Glaser, Dreyhaupt, or administrative amateurs such as Aken, dispersed information about the supposedly new knowledge of the special extinguishing capacities of saltwater or the associated application of fire-retardant substances in countless writings. Their intentions were decidedly grounded in popular Enlightenment, as the above discussion about Glaser's verbose style demonstrates: it is a proliferation of "knowledge from above," the great enemy of which, as always, are the various superstitions - such as milk presumably being a special means of extinguishing lightning-induced fires. The methods and media of these publications were modeled after the recently established notion of the scientifically verified, documented, and repeatable experiment, which justified the burning of test houses supported by money from two learned societies. ${ }^{446}$

In the context of this transformation it was now scientist-administrators who worked on the problem of security production. Here the question is less

\footnotetext{
444 Clifford Geertz, Local Knowledge: Further Essays in Interpretative Anthropology, New York 1983.

445 For a reconstruction of the the adoption of Peirce's semiotics in the founding of Polanyis's concept of "tacit knowledge" see M. Zappavigna, Tacit Knowledge and Spoken Discourse, London 2013, pp. 1-43.

446 For an overview of the subtle variations and semasio logical-semantic multiplicity of the terminology of "experience/experiment" during the Englightenment (Shapin, Jasanoff), see Claude Rosental, "Toward a Sociology of Public Demonstrations," Sociological Theory 31, 4 (2013), pp. 343-65, 343-46; and Christian Licoppe, La formation de la pratique scientifique. Le discours de l'expérience en France et en Angleterre (1630-1820), Paris 1996.
} 
related to the effect that "tacit" or "local knowledge" had overall on the genesis of innovation; instead, it primarily concerns the relationship between various strata claiming to be carriers of "knowledge" and the fashioning of certain knowledge elements as innovations. The question of how much practical tacit knowledge and how much "real" scientific knowledge combine to make an innovation is not important; instead, we should note that information was now sold as (new) scientific knowledge. This was almost certainly not done in any consciously simulating, falsifying sense, but rather reflects a somewhat unconscious appropriation of the gesture of the Enlightenment. ${ }^{447}$ If the supposed origin of the knowledge of the Enlightenment thinkers is not questioned, one easily runs the risk of assuming the perspective of Enlightenment thinkers themselves. The fact that these "experiments" were merely simulated rather than used to generate knowledge illustrates how local knowledge was translated into "scientific knowledge" and how popular Enlightenment was used to enlighten the "Volk" with their own knowledge.

Summary

Between the discussion of premodern maritime insurance as a purely spatially oriented mechanism of security production (Ch. 2) and the investigation

447 On the state of discourse about tacit knowledge in the technological process of innovation, see Paul Nightingale, "Tacit knowledge and Engineering Design," in Anthonie Meijers (ed.), Philosophy of Technology and Engineering Sciences, Amsterdam 2009, pp. 351-79; Ulrich Wengenroth, "Innovationspolitik und Innovationsforschung," in Gerd Graßhoff and Rainer C. Schwinges (eds.), Innovationskultur. Von der Wissenschaft zum Produkt, Zürich 2008, pp. 61-77. For a concrete example: Eberhard Wolff, Einschneidende Maßnahmen: Pockenschutzimpfung und traditionale Gesellschaft im Württemberg des frühen 19. Jahrhunderts, Stuttgart 1998 and further refined in the contribution: Wolff, Eberhard, “Der 'willkommene Würgeengel': Verstehende Innenperspektive und 'genaue' Quelleninterpretation - am Beispiel des erwünschten Kindertods in den Anfängen der Pockenschutzimpfung," in Martin Dinges (ed.), Neue Wege in der Seuchengeschichte, Stuttgart 1995, pp. 105-41, which more or less demonstrates that the popular Enlightenment discourse claiming that apparantly simple-minded people, affected by death of pox-infected children, declined the small pox vaccination for economic reasons, is pure speculation - rather, there were were likely other reasons at the basis of this decision. But see also Holger Böning, Hanno Schmitt, Reinhart Siegert (eds.), Volksaufklärung. Eine praktische Reformbewegung des 18. und 19. Jahrhunderts, Bremen 2007. Anne Conrad, "Aufgeklärte Elite und aufzuklärendes Volk," in Anne Conrad, Arno Herzig, and Franklin Kopitzsch (eds.), Das Volk im Visier der Aufklärung. Studien zur Popularisierung der Aufklärung im späten 18. Jahrhundert, Hamburg 1998, pp. 1-15, however rather reproduces the assessment of the Enlightenment thinkers themselves. 
that will follow concerning the emergence of a new order of safety and security around 1700 (chs. 4,5 ), this chapter 3 began with an attempt to trace the contours of the main issue that eventually led to the implementation of the new security mechanism of fire insurance: the structural problem of high fire vulnerability in the premodern building stock. In particular I focused on the greatest threat-major city fires. These fires represented, next to wars and epidemics, the greatest possible quasi-natural threat of the premodern era, exceeding the limits of conceivability and planning-assuming "planning" correctly describes the concepts of long-term future orientation accessible within a regional and small-town scope. The enormous conflagrations-the burning of 1700 houses in Dresden, of 4000 houses in Aachen or 13,200 houses in London - were not of primary interest to municipal fire funds, which had limited capacities. However, those long memorized mega-catastrophes served as symbolic representations of potential complete city destruction that became part of a general frame of thought and perception. It represented the threat of fire and stimulated developments regarding general safety measures. This also clarifies why many later theoretical contributions discussing the forms of the fire funds and of fire insurance companies referred to major fires as starting points, taken as the key data of the respective local and regional fire history (cf. below Ch. 5, 1.2, 2).

In this respect, these large fires were also invoked in the visualizations of fire danger: while in oil paintings these visualizations were initially still metonymically encoded by depictions of Biblical and mythological fires, laterespecially in the new media of copper engraving and the broadly disseminated leaflets they illustrated - an increasingly affect-oriented pictorial language developed that strongly emphasized the confrontation between the observer and the disaster itself. Fire was presented in its entire dynamic explosivity, and representations focused on the materiality of the destruction of the city. The temporalization and emotionalization of fire danger reached a peak during the seventeenth and eighteenth centuries, belying the initial detour taken during the Renaissance concerning the emotional involvement of the viewer with a represented human fire observer or fire victim. This was caused by a refinement of but also a strong dependency on the conceptual framework of ancient poetics, rhetorics and aesthetics transferred to the realm of pictorial aesthetics. The realization of the temporalized and emotionalized totality of the fire as the main subject of the representation did not have its counterpart in a simple erosion of retribution theology in the sense of a unilinear secularization process. On the contrary, it is striking how unchanged the genre of the fire sermon remained-with its Biblical topoi and recourse to the Biblical Sodom and Gomorrah fires - until the end of early modernity. Rather, a 
differentiation and unfolding in different areas of the possibilities of reaction clearly occurs, so that, for example, literary emotionalized reactions appear in addition to the sermons, without completely replacing them.

All these forms would seem to give voice to a stronger power of stimulation within the cultural domain; however, this would still imply a simplistic model, placing image, graphics, sermons, literature, and other texts in a simple causal logic of stimulating action. Yet even if this is interpreted as correlation rather than cause, as an indicator for other fields (administrative and fire prevention practice), this is still significant enough: making the representation of fire absolute beyond all human reaction symbolizes the genesis of the modern concept of disaster. The manufacture of the totalizing exceptional case existing beyond the norm of societal safety and security — which is presupposed but which must also be created - is realized here. The fact that increasingly from 1700 on this notion of a "normal secure society" was constructed will be discussed later (see Ch. 5).

Thus, the perspective in the preceding chapter (Ch. 3, 3) focused on this development in the field of fire policey. Three administrative types were distinguished and compared: Cologne, as the largest medieval imperial city, was avant-garde in this area until the end of the late Middle Ages. Through comparison with other similar cities, it becomes clear that larger traditional, bureaucratically and administratively disciplined, successful cities had a higher degree of security at the end of the Middle Ages in relation to other hamlets, villages, and territorial cities-not insignificantly due to the large proportion of stone buildings in the city centers, but also because of fire policey ordinances and inspection practices. This is clearly reflected in the German fire statistics taken as a whole, in which there are hardly any major fires documented in large imperial cities at all - with few exceptions such as Aachen, whose building stock was heavily half-timbered.

Accordingly, because these large cities were mostly spared, the ensuing progress during the seventeenth and eighteenth centuries was also slow in these cities. Domination in the area of security innovation was quickly assumed by the fast-growing cities and territorial capitals, as well as those subsumed by the northern German territorial administrations-Prussia and its provinces in particular. This may seem strange at first glance, in light of the early modern research of the last few decades, which has celebrated the customs, structures, and administrative traditions of the Holy Roman Empire. While there are some tendencies within Prussian historiography which held the national state embodied by Prussia to be the teleological endpoint of all developments, the significance of the Holy Roman Empire's protofederalist and consensusbuilding qualities — its "different modernity" — has been emphasized in more 
recent literature. Nevertheless, this much deserved reevaluation of the empire has very little relevance for some historical topics: the administrative structures and institutions of the empire contributed next to nothing to the development of new territorial and urban measures of security production in the fields addressed here. The revisionist approach to the history of the Holy Roman Empire is quite legitimate for the sixteenth and seventeenth centuries. But emphasizing the vitality of the empire for large parts of the eighteenth century necessitates a focus on forms not realized (imperial reform projects), on discursive fields (imperial patriotism), or on regions characterized by small territories where the empire substantially limited its function to the consolidation of interterritorial cooperation and the support of border defense and other tasks that could not be fulfilled on a local level.

In terms of the questions at stake here, it is difficult to come to different conclusions regarding the impulses and stimuli of development. Hamburg and Prussia are forerunners in fire security innovation, although or because of the fact that Hamburg was home to some of the most destructive conflagrations in Germany during this time period —in the 166os, 1683 , and in 1842-and was therefore a fairly "unsafe" city. Apart from the generally rather fire-resistant eighteenth century, these fires were symptomatic of a riskier path paved by increasing trade volumes, by population expansion, and at the beginning of the nineteenth century, by early industrialization. This resulted in higher pressure for the development of security production.

The Prussian provinces, in contrast, constituted a laboratory of sorts for the institution of widespread territorialized coverage of cities and villages in that the innovation potential was mainly concerned with the area of infrastructure and the "objectification" of the small territorial cities as a whole. In Prussia, the externalized image of cities as "objects" to be organized and reformed was a prerequisite for the implementation of innovations, while the largely autonomous imperial cities obviously lacked the development of a functionally equivalent stance of reflective self-observation as a starting point for innovation. This small difference, which is actually a matter of different modes of perception rather than a material difference of structures, of the quality of stones and wood used for building the cities, seems to be the main difference clarifying why the cities of administrative states like Prussia possessed an entirely different motivation for the development of a widespread and far-reaching security culture.

Finally, the object of this last section was a reflection on the paths of innovation. One widely generalizable phenomenon in popular Enlightenment is particularly noteworthy: a number of technical innovations were passed down by generations of craftsmen or "project makers" and "quacks" in the seventeenth century. The knowledge-based methodization of fire prevention and 
firefighting then increased and was transformed around 1750 in a trend toward scientification. At this point, well-known local knowledge was at least partially transformed and sublimated into Enlightenment scientific discourse in a type of historical feedback loop. The "Enlighteners" simply translated such knowledge into the code of scientific "inventions," which were then experimentally validated and published in scientific media. Information coded in this way was then recognized as Enlightenment knowledge and disseminated among the supposedly clueless "Volk" with all the usual popular Enlightenment rhetoric, lamenting the uninformed and stubborn nature of ignorant people. In several other treatments of popular Enlightenment, parallel phenomena have been observed; in general, however, popular Enlightenment research still risks following the rhetoric and self-definition of the Enlighteners themselves, believing too strongly in their own innovativeness. Some inventions, such as the lightning rod, really were heretofore unimagined elements of knowledge that found their way from above down to the "Volk," but the paths were often much more complex.

This all leads to the realization that beyond the representation and perception of fire danger treated in this chapter, and beyond the development of an administrative-technical level of innovation concerning measures of prevention and firefighting, it is the construction of a new "normality," a normal world conceived to be normally free of danger, to be normally secure and safe, in which insecurity becomes the exception. This emerging conceptual configuration and reversal of that what was previously regarded as the "normal state of things," is probably at least as important as the back-and-forth in practical administrative communication concerning the details of the aforementioned measures: but both the steady communication and the emerging reversal of the fundamental assumption of what is or should be normal were interdependent. This interdependence will be the focus of the next two chapters. 